\title{
Basic Data Report for Well Plugging and Abandonment and Reconfiguration Activities for Fiscal Year 2005
}

\author{
WASTE ISOLATION PILOT PLANT \\ U.S. DEPARTMENT OF ENERGY \\ CARLSBAD FIELD OFFICE
}

MARCH 2006

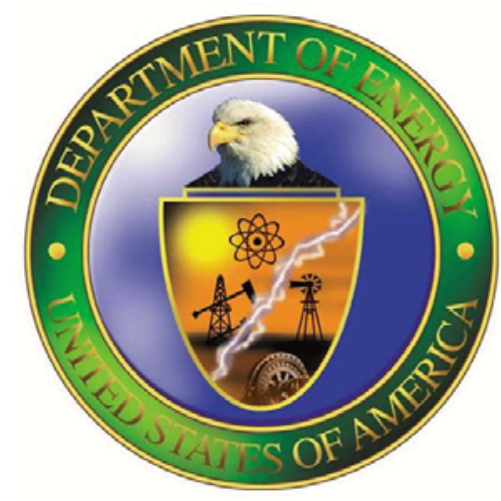




\section{Basic Data Report for Well Plugging and Abandonment and Reconfiguration Activities for Fiscal Year 2005

This document has been submitted as required to:

Office of Scientific and Technical Information

P.O. Box 62

Oak Ridge, TN 37831

(615) $576-8401$

Additional information about this document may be obtained by calling (800) 336-9477. Copies may be obtained by contacting the National Technical Information Service, U.S. Department of Commerce, 5285 Port Royal Road, Springfield, VA 22101.

Processing and final preparation of this report was performed by the Waste Isolation Pilot Plant Management and Operating Contractor for the U.S. Department of Energy under Contract No. DE-AC04-29AL66444. 


\author{
BASIC DATA REPORT \\ FOR WELL PLUGGING AND ABANDONMENT AND \\ RECONFIGURATION ACTIVITIES FOR FISCAL YEAR 2005 \\ (WASTE ISOLATION PILOT PLANT)
}

\author{
Richard A. Salness \\ Washington Regulatory and Environmental Services \\ P.O. Box 2078 \\ Carlsbad, NM 88220
}

MARCH 2006 


\section{TABLE OF CONTENTS}

LIST OF FIGURES $\ldots \ldots \ldots \ldots \ldots \ldots \ldots \ldots \ldots \ldots \ldots \ldots \ldots \ldots \ldots \ldots \ldots \ldots$

ABBREVIATIONS AND ACRONYMS $\ldots \ldots \ldots \ldots \ldots \ldots \ldots \ldots \ldots$

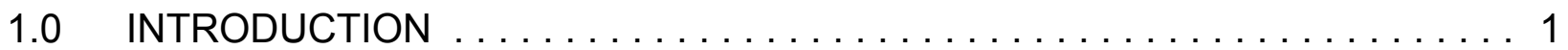

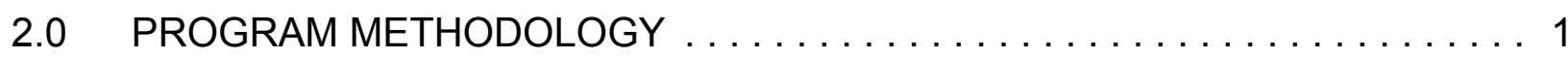

2.1 Removal of Well Appurtenances - Retrieval Tools . . . . . . . . . 3

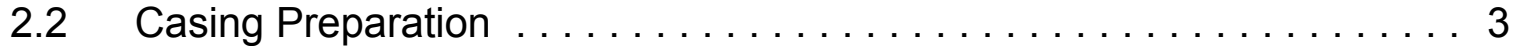

2.3 Well Circulation ............................ 3

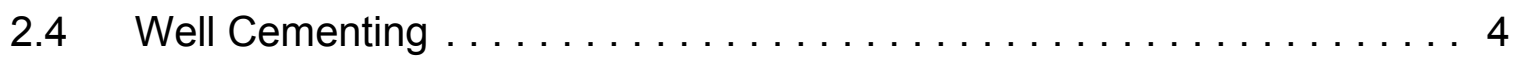

2.5 Well Monuments ......................... 4

2.6 Well Head Alterations . . . . . . . . . . . . . . . . . . 4

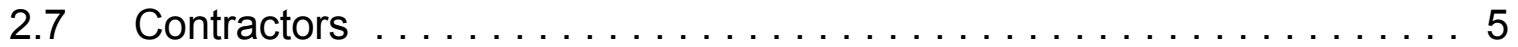

3.0 FISCAL YEAR 2005 WELL P\&A AND RECONFIGURATION PROGRAM WASTE MANAGEMENT PRACTICES $\ldots \ldots \ldots \ldots \ldots \ldots \ldots \ldots$

4.0 REGULATORY ISSUES $\ldots \ldots \ldots \ldots \ldots \ldots \ldots \ldots \ldots \ldots \ldots \ldots \ldots$

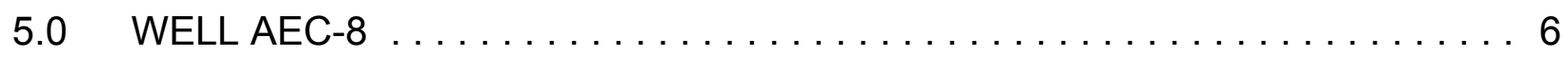

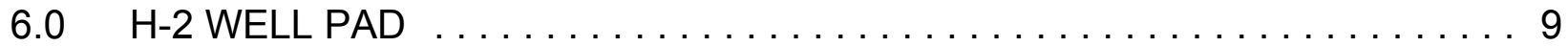

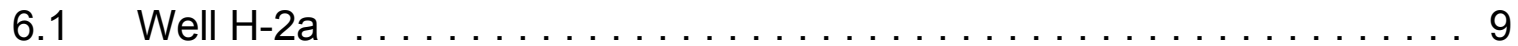

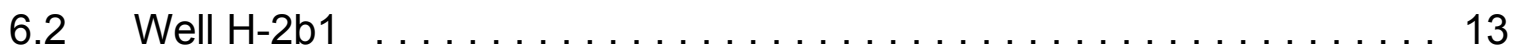

$6.3 \quad$ Well $\mathrm{H}-2 \mathrm{~b} 2$ and Well $\mathrm{H}-2 \mathrm{c} \ldots \ldots \ldots \ldots \ldots \ldots \ldots \ldots \ldots \ldots \ldots \ldots \ldots \ldots \ldots \ldots \ldots$

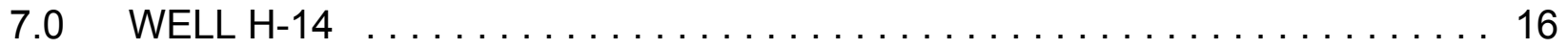

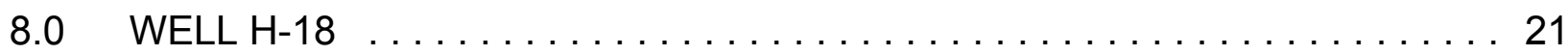

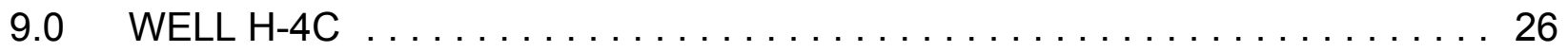

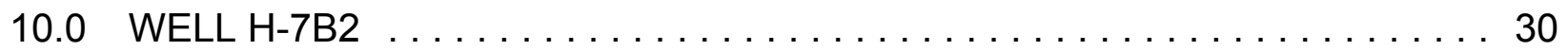

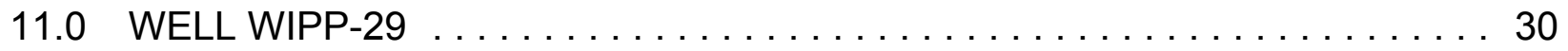

$12.0 \mathrm{H}-6$ WELL PAD $\ldots \ldots \ldots \ldots \ldots \ldots \ldots \ldots \ldots \ldots \ldots \ldots \ldots \ldots \ldots \ldots \ldots$

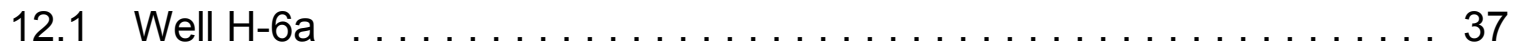

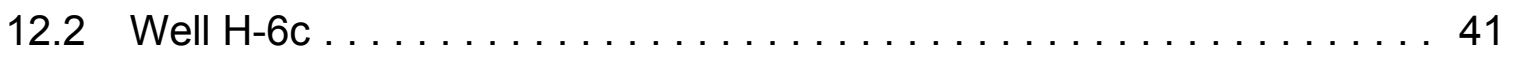

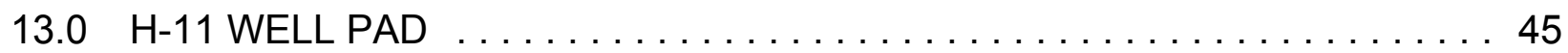

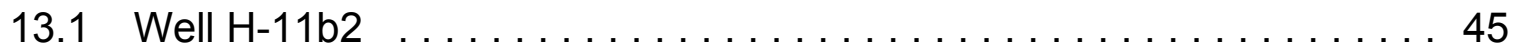

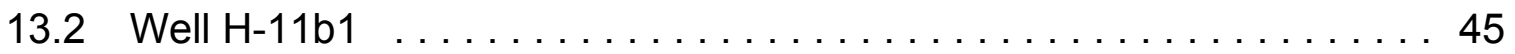

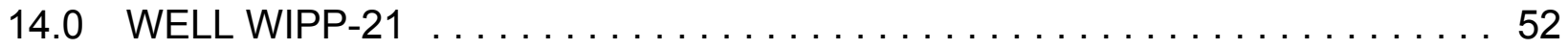


Basic Data Report for Well Plugging and Abandonment and

Reconfiguration Activities for Fiscal Year 2005

DOE/WIPP 05-3326

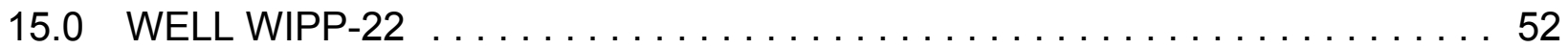

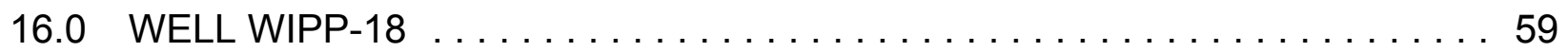

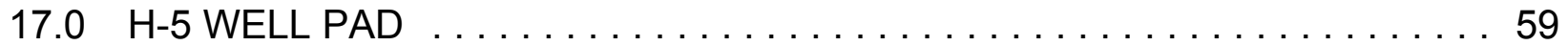

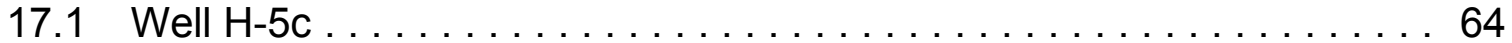

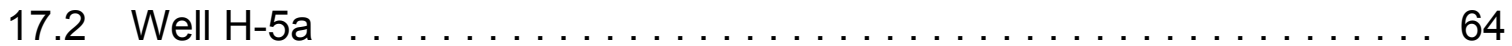

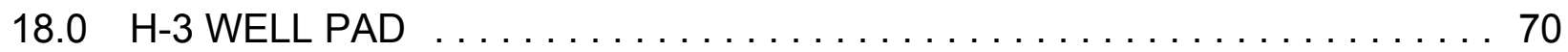

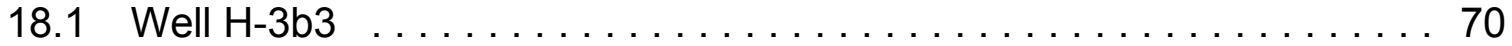

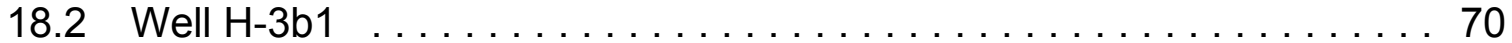

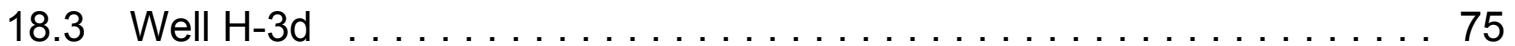

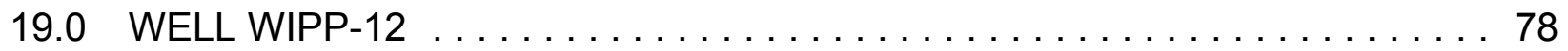

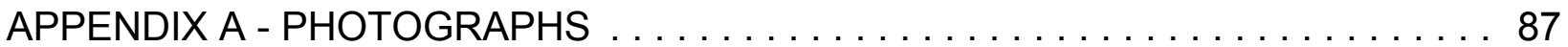




\section{Basic Data Report for Well Plugging and Abandonment and Reconfiguration Activities for Fiscal Year 2005 \\ DOE/WIPP 05-3326}

\section{LIST OF FIGURES}

Figure 1 - WIPP Location in Southeastern New Mexico . . . . . . . . . . . 2

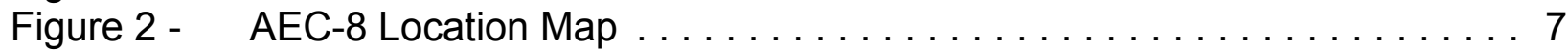

Figure 3 - Configuration of AEC-8 Before P\&A $\ldots \ldots \ldots \ldots \ldots \ldots \ldots \ldots$

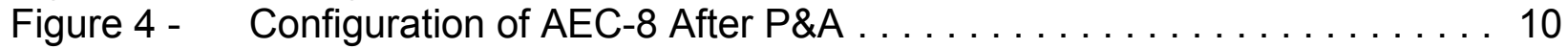

Figure 5 - $\quad \mathrm{H}-2$ Well Pad Location Map . . . . . . . . . . . . . . . . . . . . 11

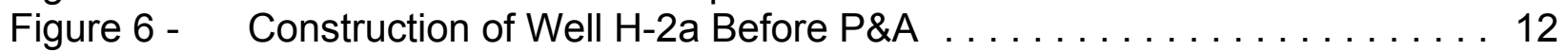

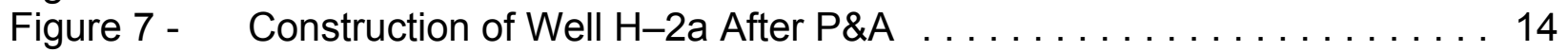

Figure 8 - Construction of Well H-2b1 Before Reconfiguration . . . . . . . . . . 15

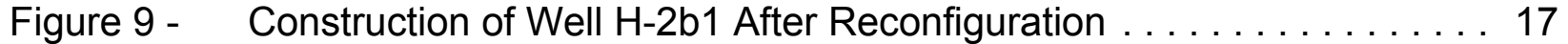

Figure 10 - Construction of Well H-2c Before P\&A . . . . . . . . . . . . . . . 18

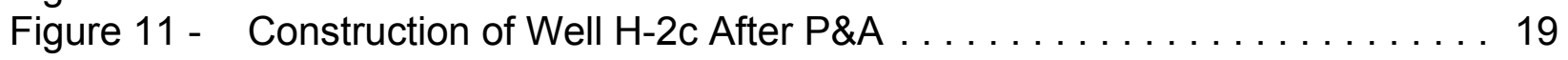

Figure 12 - $\mathrm{H}-14$ Well Pad Location Map . . . . . . . . . . . . . . . . 20

Figure 13 - $\mathrm{H}$-14 Construction Before Reconfiguration . . . . . . . . . . . . . 22

Figure 14 - Construction of Well H-14 After Reconfiguration . . . . . . . . . . . . 23

Figure 15 - $\mathrm{H}-18$ Location Map . . . . . . . . . . . . . . . . . . . 24

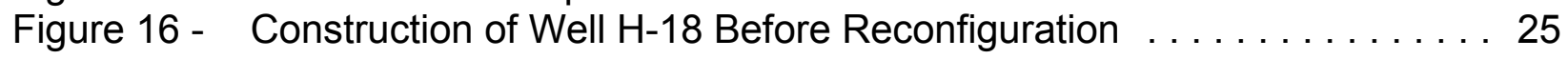

Figure 17 - Construction of Well H-18 After Reconfiguration . . . . . . . . . . . 27

Figure 18 - H-4 Well Pad Location Map . . . . . . . . . . . . . . . . . 28

Figure 19 - Construction of Well H-4c Before Reconfiguration . . . . . . . . . . . 29

Figure 20 - Construction of Well H-4c After Reconfiguration . . . . . . . . . . . 31

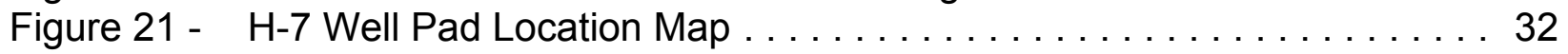

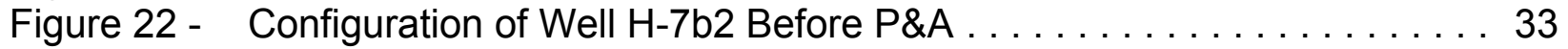

Figure 23 - Configuration of Well H-7b2 After P\&A . . . . . . . . . . . . . 34

Figure 24 - WIPP-29 Location Map . . . . . . . . . . . . . . . . . . . . 35

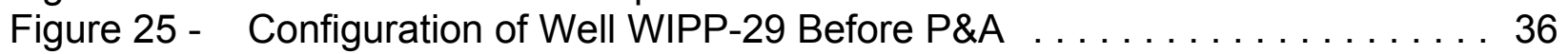

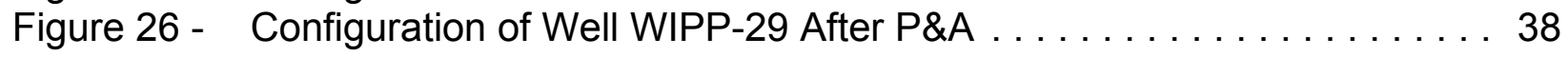

Figure 27 - H-6 Well Pad Location Map . . . . . . . . . . . . . . . . . . 39

Figure 28 - Construction of Well H-6a Before P\&A . . . . . . . . . . . . . . . . 40

Figure 29 - Construction of Well H-6a After Reconfiguration . . . . . . . . . . . . 42

Figure 30 - Construction of Well H-6c Before Reconfiguration . . . . . . . . . 43

Figure 31 - Construction of Well H-6c After Reconfiguration . . . . . . . . . . . . 44

Figure 32 - $\mathrm{H}-11$ Well Pad Location Map . . . . . . . . . . . . . . . . . 47

Figure 33 - Construction of Well H-11b2 Before Reconfiguration . . . . . . . . . 48

Figure 34 - Construction of Well H-11b2 After Reconfiguration . . . . . . . . . . . 49

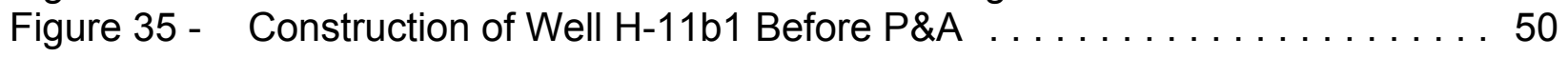

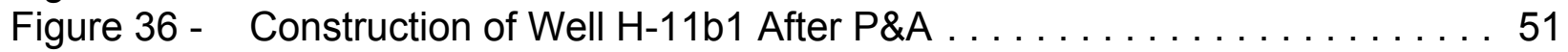

Figure 37 - WIPP-21 Location Map . . . . . . . . . . . . . . . . . . . . 53

Figure 38 - Configuration of Well WIPP-21 Before P\&A . . . . . . . . . . . . 54

Figure 39 - Configuration of Well WIPP-21 After P\&A . . . . . . . . . . . . 55

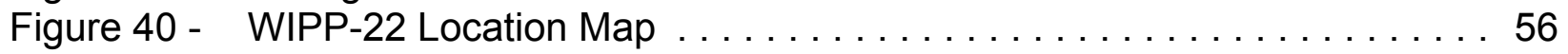

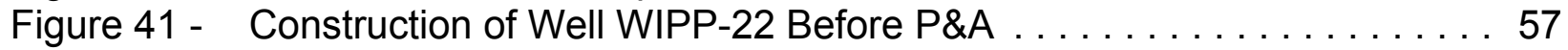

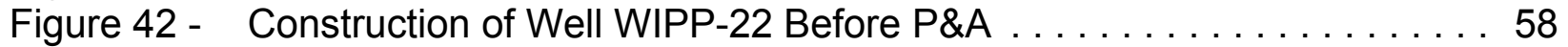

Figure 43 - WIPP-18 Location Map . . . . . . . . . . . . . . . . . . . . 60

Figure 44 - Construction of Well WIPP-18 Before Reconfiguration . . . . . . . . 61 


\section{Basic Data Report for Well Plugging and Abandonment and Reconfiguration Activities for Fiscal Year 2005 \\ DOE/WIPP 05-3326}

Figure 45 - Construction of Well WIPP-18 After Reconfiguration . . . . . . . . 62

Figure 46 - H-5 Well Pad Location Map . . . . . . . . . . . . . . . . . . 63

Figure 47 - Construction of Well H-5c Before Reconfiguration . . . . . . . . 66

Figure 48 - Construction of Well H-5c After Reconfiguration . . . . . . . . . . . 67

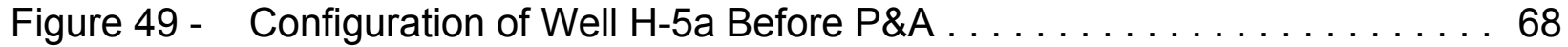

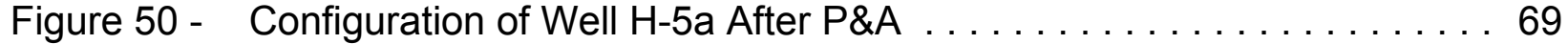

Figure 51 - H-3 Well Pad Location Map . . . . . . . . . . . . . . . . . . . . 71

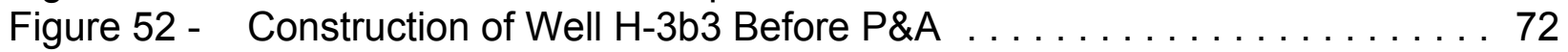

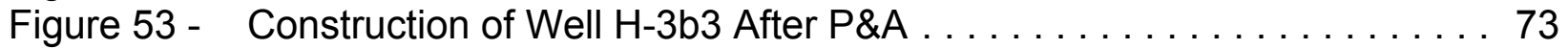

Figure 54 - Construction of Well H-3b1 Before Reconfiguration . . . . . . . . . 74

Figure 55 - Construction of Well H-3b1 After Reconfiguration . . . . . . . . . . . . 76

Figure 56 - Construction of Well H-3d Before Reconfiguration . . . . . . . . . . . . 77

Figure 57 - Construction of Well H-3d After Reconfiguration (Large Scale) . . . . 80

Figure 58 - Construction of Well H-3d After Reconfiguration (Detail) . . . . . . . 81

Figure 59 - WIPP-12 Location Map . . . . . . . . . . . . . . . . . . . 82

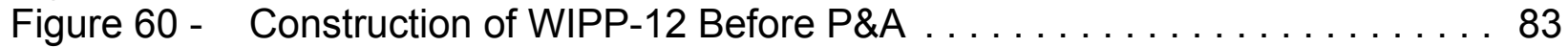

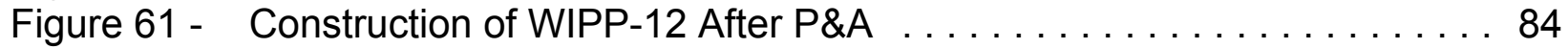




\section{ABBREVIATIONS AND ACRONYMS}

\begin{tabular}{|c|c|}
\hline AMSL & above mean sea level \\
\hline bgs & below ground surface \\
\hline BLM & U.S. Bureau of Land Management \\
\hline BOP & blowout preventer \\
\hline CBFO & Carlsbad Field Office (DOE) \\
\hline DOE & U.S. Department of Energy \\
\hline FY & fiscal year \\
\hline $\mathrm{H}_{2} \mathrm{~S}$ & hydrogen sulfide gas \\
\hline NMED & New Mexico Environment Department \\
\hline NMOCD & New Mexico Oil and Gas Conservation Division \\
\hline NMOSE & New Mexico Office of the State Engineer \\
\hline P\&A & plugging and abandonment \\
\hline PIP & production-injection packer \\
\hline RCRA & Resource Conservation and Recovery Act \\
\hline SNL & Sandia National Laboratories \\
\hline TCLP & Toxicity Characteristic Leaching Procedure \\
\hline WIPP & Waste Isolation Pilot Plant \\
\hline
\end{tabular}




\section{Basic Data Report for Well Plugging and Abandonment and Reconfiguration Activities for Fiscal Year 2005 \\ DOE/WIPP 05-3326}

\subsection{INTRODUCTION}

The Waste Isolation Pilot Plant (WIPP) is a U.S. Department of Energy (DOE) facility disposing of transuranic and mixed waste under a permit issued by the New Mexico Environment Department (NMED). WIPP is located 26 miles east of Carlsbad, New Mexico, in eastern Eddy County (Figure 1). Disposal panels are mined in the Permian Salado Formation at a depth of about 2,150 feet below ground surface (bgs).

Over the years a number of groundwater monitor wells have been installed for site characterization and to monitor temporal and spatial changes in groundwater elevation and chemistry at WIPP. Many of the wells in the fiscal year (FY) 2005 program were selected for plugging and abandonment (P\&A) due to redundancy. In other words, the well pads have multiple wells that monitor the Culebra ("Culebra") Member of the Rustler Formation when only one is necessary. These multi-well locations are a relic of various aquifer testing programs associated with the site characterization of WIPP. Additionally, the multi-well locations had wells that were completed in both the Culebra and the Magenta ("Magenta") Members of the Rustler Formation for dual monitoring of these intervals. The intervals were separated by inflatable packers used as bridge plugs, and over the years these packers have aged and their integrity compromised. For these wells, the packers were removed and the wells were converted to Magenta-only monitor wells.

The FY 2005 program was initiated on March 31, 2005, and concluded on July 16, 2005. The FY 2005 program initially included 25 wells requiring workover (P\&A, Magenta reconfiguration, cleaning and keeping). During the process, the U.S. Bureau of Land Management (BLM) requested transfer of two wells $(\mathrm{H}-7 \mathrm{c}$ and $\mathrm{H}-8 \mathrm{c})$ to their ownership for future livestock watering. These wells were transferred to the BLM through execution of Form wr-03, Declaration of Owner of Underground Water Rights, between the New Mexico Office of the State Engineer (NMOSE), the BLM, and the DOE Carlsbad Field Office (CBFO). One well ( $\mathrm{H}-2 \mathrm{~b} 2)$ was cleaned and retained as a Culebra monitor well for continued use. One well $(\mathrm{H}-3 \mathrm{~d})$ was converted to a shallow well to monitor the formational contact between the Dewey Lake Redbeds Formation and the Santa Rosa Formation in support of the DP-831 discharge permit monitoring program. Nine dual-completion wells were reconfigured as Magenta-only monitor wells, and 12 wells were plugged and abandoned permanently.

This report presents the summary in the same order that the wells were worked in the field.

\subsection{PROGRAM METHODOLOGY}

For this program, the general process for each type of work was identical between wells. All wells were processed by first removing all appurtenances, like tubing, packers, bridge plugs, and in some cases old testing equipment and associated transducer wires. All wells were scraped to remove oxidation scale from the casing to allow a good bond between the casing and cement. 
Basic Data Report for Well Plugging and Abandonment and Reconfiguration Activities for Fiscal Year 2005

DOE/WIPP 05-3326

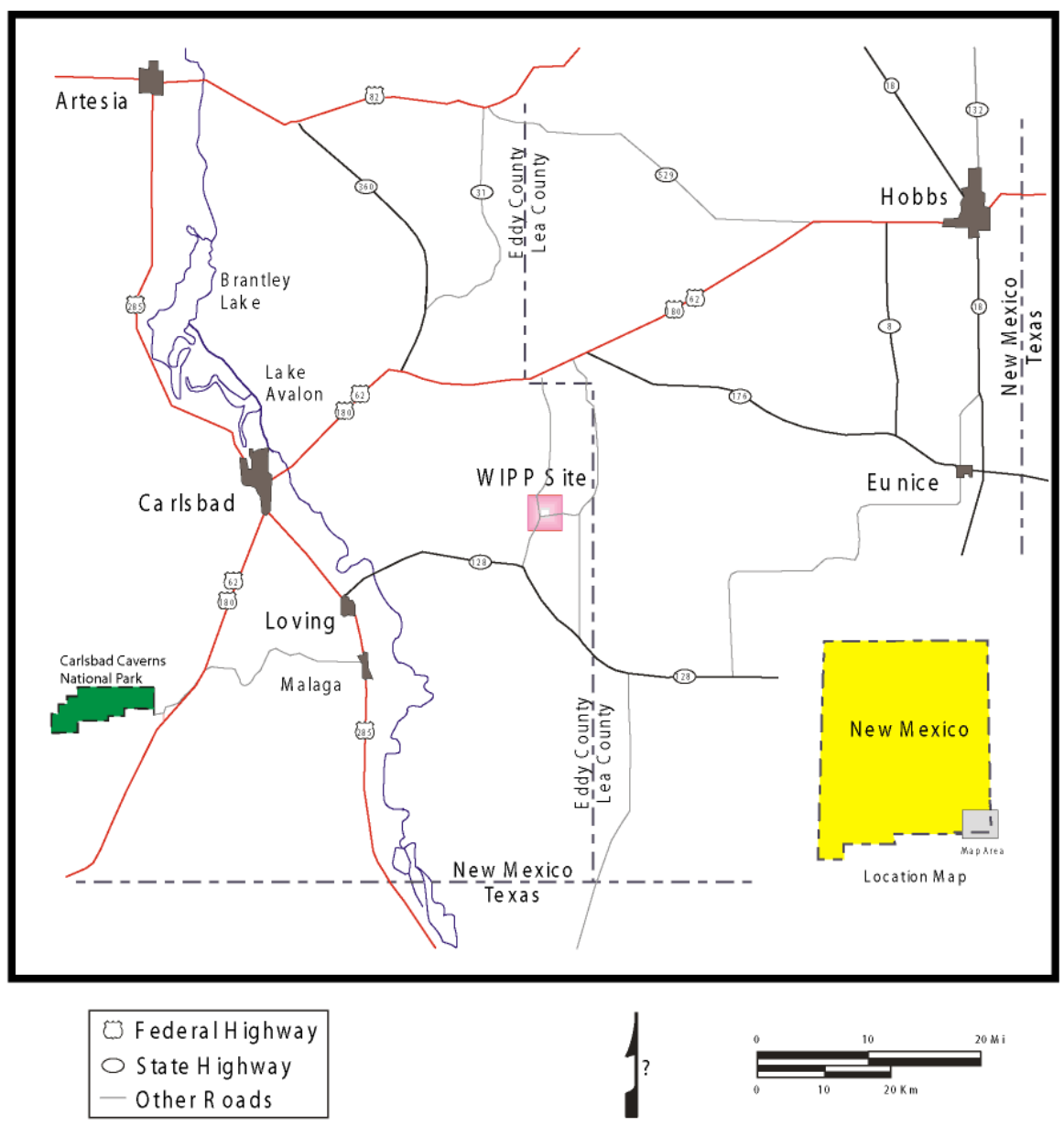

Figure 1 WIPP Location in Southeastern New Mexico 


\section{Basic Data Report for Well Plugging and Abandonment and Reconfiguration Activities for Fiscal Year 2005 \\ DOE/WIPP 05-3326}

After scraping, the wells were circulated to remove all debris from the well to the total depth, followed by cementing. The following sections describe the general process. Individual well sections describe specific nuances and problems encountered during the process.

\subsection{Removal of Well Appurtenances - Retrieval Tools}

Not all the wells contained packers, bridge plugs, and/or forgotten testing equipment, but in most wells there was equipment of some sort that needed removal. For some wells, the process was simple and the equipment was removed without incident. For others, because of equipment age or the age of the well, difficulties were encountered and in some cases packers were driven to the bottom of the well and cemented in with permission of the NMOSE.

In some cases, inflatable packers were attached to 2.375 -inch tubing or 1.5 -inch pipe. Removal of packers in this type of configuration involved attaching the tubing to the drilling rig elevators and pulling on the tubing to release the packer pressure. Once the packer was released, the tubing was removed one joint at a time until the packer was removed from the well at the surface.

Some wells had inflatable packers that were set in the wells without tubing. For these cases, the packers were released and removed from the well using retrieval tools, such as J-hooks, or a combination overshot and grapples. The tools were similar to those originally used to set the plug, and were attached to the drill rig 2.875-inch tubing one joint at a time until reaching the packer. The J-tool then was inserted over the packer and turned until latching onto the packer lugs. Once attached, the packer pressure was released and the packer removed from the well.

\subsection{Casing Preparation}

Some wells in the FY 2005 program were totally cased to the bottom of the well, while some were only partially cased. To ensure the well casing was cleaned of residue and scale, each were scraped using various sizes of Weatherford Type $E$ casing scrapers (Photo 1) in Appendix A. The scraper was attached to the drill rig tubing (2.875-inch) and placed into the well one tubing joint at a time. At each tubing joint interval the tool was moved up and down the full length of the tubing joint for at least three passes or until there was no longer any resistance from the tool and casing. This process was repeated for the entire length of the casing for each applicable well.

\subsection{Well Circulation}

After scraping, the debris needed to be removed from the well to the total depth First, the well was fitted with a flow nipple to direct circulated water into a tub for collection. Then the well was circulated by using the 2.875 -inch tubing as a tremmie pipe installed into the well until the top of the collected debris was encountered. The tremmie pipe was plumbed to the drill rig pumps that were plumbed to a freshwater transport truck. 


\section{Basic Data Report for Well Plugging and Abandonment and Reconfiguration Activities for Fiscal Year 2005 \\ DOE/WIPP 05-3326}

Water was circulated into the hole through the tremmie pipe and flowed out of the hole at the surface via a well mounted flow nipple. The circulated water and debris were captured at the surface by a tub, then pumped into a storage tank (Photo 2). The well was circulated until clear return water appeared at the surface. At this point, the well was ready for cement.

\section{$2.4 \quad$ Well Cementing}

After the well appurtenances were removed from the well and the existing casing was scraped to remove scale, the scraping tool was removed from the hole and the hole was reentered with tremmie pipe (2-3/8 inch upset pipe) to the total depth of the hole. The tremmie pipe was then pulled back so that the open end was eight to ten feet from total depth At this point the hole was filled with Class $C$ Neat cement slurry mixed with fresh water (Photo 3 ) in a ratio of 19 sacks of cement to 7 gallons of fresh water yielding 27 cubic feet of cement slurry.

All cement was brought on-site by cement trucks where the cement was either poured into a tub or directly into a grout pump (Photo 4). For deep wells, the cement was poured into a tub and extracted via the drill rig pumps and into the tremmie pipes to the bottom of the hole. For shallow wells, the grout pump transported the cement slurry directly to the tremmie pipe. Each cement truck emptied approximately one half of each load into the hole before any tremmie pipe was removed, thus submerging approximately 300 feet of pipe (10 joints), ensuring a continuous plug from bottom of the hole to the surface. This process was followed until all cement was placed into the hole. Cement quantities placed throughout this program closely matched the theoretical calculated borehole volume, indicating no significant voids in the cement and no large openings in the uncased formations.

\subsection{Well Monuments}

The BLM requires that wells permanently abandoned be marked with a monument. The monument must be at least four inches in diameter and long enough to include the following information welded onto the steel: County, Section, Township, Range, NMOSE \#, WIPP, and the BLM right-of-way reservation number. These monuments must also be painted per BLM Visual Contrast requirements. At the time of this program, the monuments were required to be desert tan if no more active wells were on the pad, and blue if there were still wells on the pad that were being used for monitoring. For an example of one painted desert tan, see Photo 15.

\subsection{Well Head Alterations}

Certain well heads were altered (cut, welded flow nipples, etc.) on wells that were reconfigured for future use as Magenta wells. This affected the top of casing (measuring point) elevation for water level measurements. 


\section{Basic Data Report for Well Plugging and Abandonment and Reconfiguration Activities for Fiscal Year 2005 DOE/WIPP 05-3326}

The affected wells and revised reference point elevations are shown in Table 1.

\begin{tabular}{|c|c|c|}
\hline \multicolumn{3}{|c|}{ Table 1 - Revised Top of Casing Elevations } \\
\hline Well I.D. & $\begin{array}{c}\text { Top of Casing Elevation } \\
\left(\text { feet ams }{ }^{*}\right)\end{array}$ & $\begin{array}{c}\text { Surface Elevation } \\
(\text { feet amsl) }\end{array}$ \\
\hline WIPP-18 & 3457.74 & 3456 \\
\hline H-3d & 3390.71 & 3387 \\
\hline H-3b1 & 3390.68 & 3389 \\
\hline H-2b1 & 3378.47 & 3378 \\
\hline H-2b2 & 3378.31 & 3377 \\
\hline H-14 & 3347.13 & 3346 \\
\hline H-4c & 3334.09 & 3334 \\
\hline H-11b2 & 3411.91 & 3411 \\
\hline H-5c & 3506.06 & 3506 \\
\hline H-18 & 3414.27 & 3413 \\
\hline H-6c & 3348.52 & 3348 \\
\hline
\end{tabular}

${ }^{*}$ above mean sea level

\subsection{Contractors}

Washington Regulatory and Environmental Services, an affiliate of Washington TRU Solutions LLC, managed this program, which included technical, regulatory, contracts, financial, and field oversight.

The prime subcontractor was Stewart Brothers Drilling Company of Milan, New Mexico. Stewart Brothers employed Weatherford Tools of Hobbs, New Mexico; Southwest Safety Specialists, Inc. of Hobbs, New Mexico; Schlumberger of Hobbs, New Mexico for geophysics, and LaFarge and Southwest Ready Mix, both of Carlsbad, New Mexico, for cement.

\subsection{FISCAL YEAR 2005 WELL P\&A AND RECONFIGURATION PROGRAM WASTE MANAGEMENT PRACTICES}

During P\&A and reconfiguration activities, native brine water in the borehole was displaced to the surface. The water was captured from the wellhead casing through a right-angle flow nipple at the surface, then into a tub. A transfer pump moved the water from the tub into a 500-barrel tank for storage prior to disposal. The captured water was characterized for disposal by analysis using Toxicity Characteristic Leaching Procedure (TCLP). The TCLP analyses were performed for Resource Conservation and Recovery Act (RCRA) metals. For all water, the analyses (whether by well or well composites) indicated that the brine water was not a hazardous waste. Following receipt of the analytical results, the brine water collected from the wells was disposed of at Sundance Services, Inc. in Eunice, New Mexico. 


\section{Basic Data Report for Well Plugging and Abandonment and Reconfiguration Activities for Fiscal Year 2005 \\ DOE/WIPP 05-3326}

Trash and debris from construction (i.e., old cement) were disposed of in a centralized open-top dumpster located on the H-3 well pad. After the FY 2005 program was completed, the trash was disposed of at Lea Land Inc.

\subsection{REGULATORY ISSUES}

For these wells, the NMOSE had regulatory primacy over P\&A and reconfiguration activities. The NMOSE Roswell Representative was briefed during each well plugging activity and made frequent visits to observe the cementing process while plugging the wells. The NMOSE was always consulted during this program when the planned activities for a well changed. Plans were typically changed when a packer, tubing, or other down-hole equipment could not be taken out of the well and needed to be left in the well when cementing. For all cases where "equipment" was cemented in the hole, prior approval from the NMOSE was obtained before completion. Within ten days after the activities occurred at each well, a NMOSE Form wr-20, New Mexico Office of the State Engineer Well Record, was completed and submitted by Stewart Brothers to the NMOSE to document the activities.

The BLM and the New Mexico Oil and Gas Conservation Division (NMOCD) were consulted on this project to obtain a variance from using brine-saturated cement when plugging well WIPP-12. Both regulatory agencies cited that it was acceptable to use fresh water to mix Class $C$ Neat cement for the purpose of plugging. Additionally, the NMOCD claimed that regulatory responsibilities for water wells were not within their jurisdiction. Based on these waivers from the regulatory agencies, well WIPP-12 was plugged using a freshwater mix of Class $\mathrm{C}$ Neat cement.

\subsection{WELL AEC-8}

Well AEC-8 is located approximately one mile northeast of the northeastern corner of the WIPP site boundary in Section 11, Township 21 south, Range 31 east (Figure 2). AEC-8 was originally drilled to a depth of 3,019 feet bgs in 1974 , and deepened to 4,910 feet bgs in 1976 (Figure 3). The borehole was cased with a 5.5-inch casing string to a depth of 4,907 feet bgs. After deepening, a production-injection packer (PIP) was set in the casing at $4,825.5$ feet (center) on 2.375 -inch tubing to monitor the Bell Canyon Formation through two sets of perforations from 4,810 to 4,816 feet bgs and from 4,832 to 4,845 feet bgs (Sandia National Laboratories [SNL] and D'Appolonia Consulting Engineers 1983).

The goal for well AEC-8 was to plug and abandon the well. Work on this well began on March 31, 2005, and concluded on April 6, 2005. The workover activities began with the removal of the valve head and flare lines at the well head, remnants of the initial installation of the well. Removal of the packer and tubing were performed as described in Section 2.0 of this report. This packer and tubing removal process was performed without incident. 


\section{Basic Data Report for Well Plugging and Abandonment and Reconfiguration Activities for Fiscal Year 2005

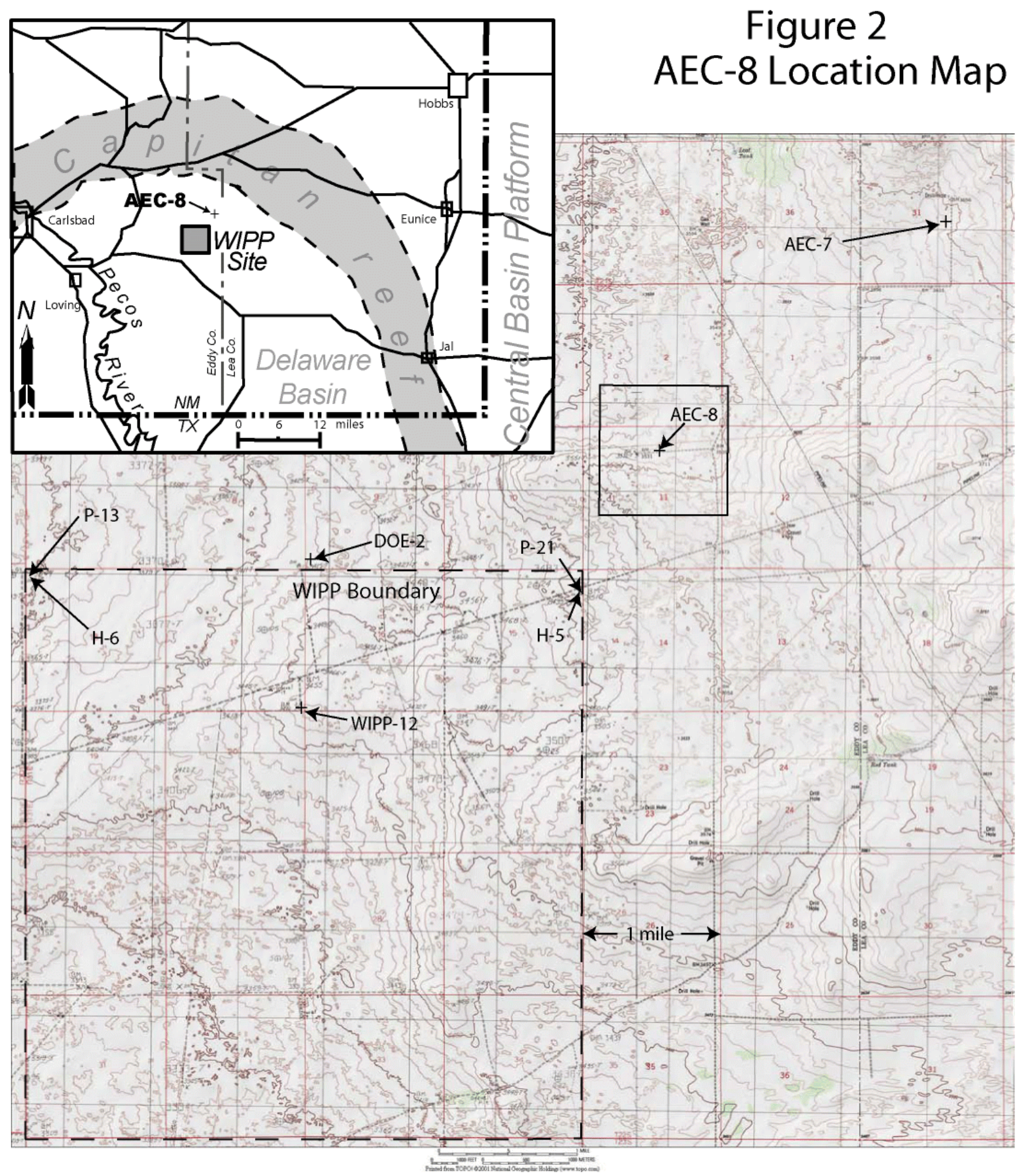




\section{Basic Data Report for Well Plugging and Abandonment and Reconfiguration Activities for Fiscal Year 2005

Figure 3

Configuration of AEC- 8

Before P\&A

(Not to Scale)

Protective Lodkbox
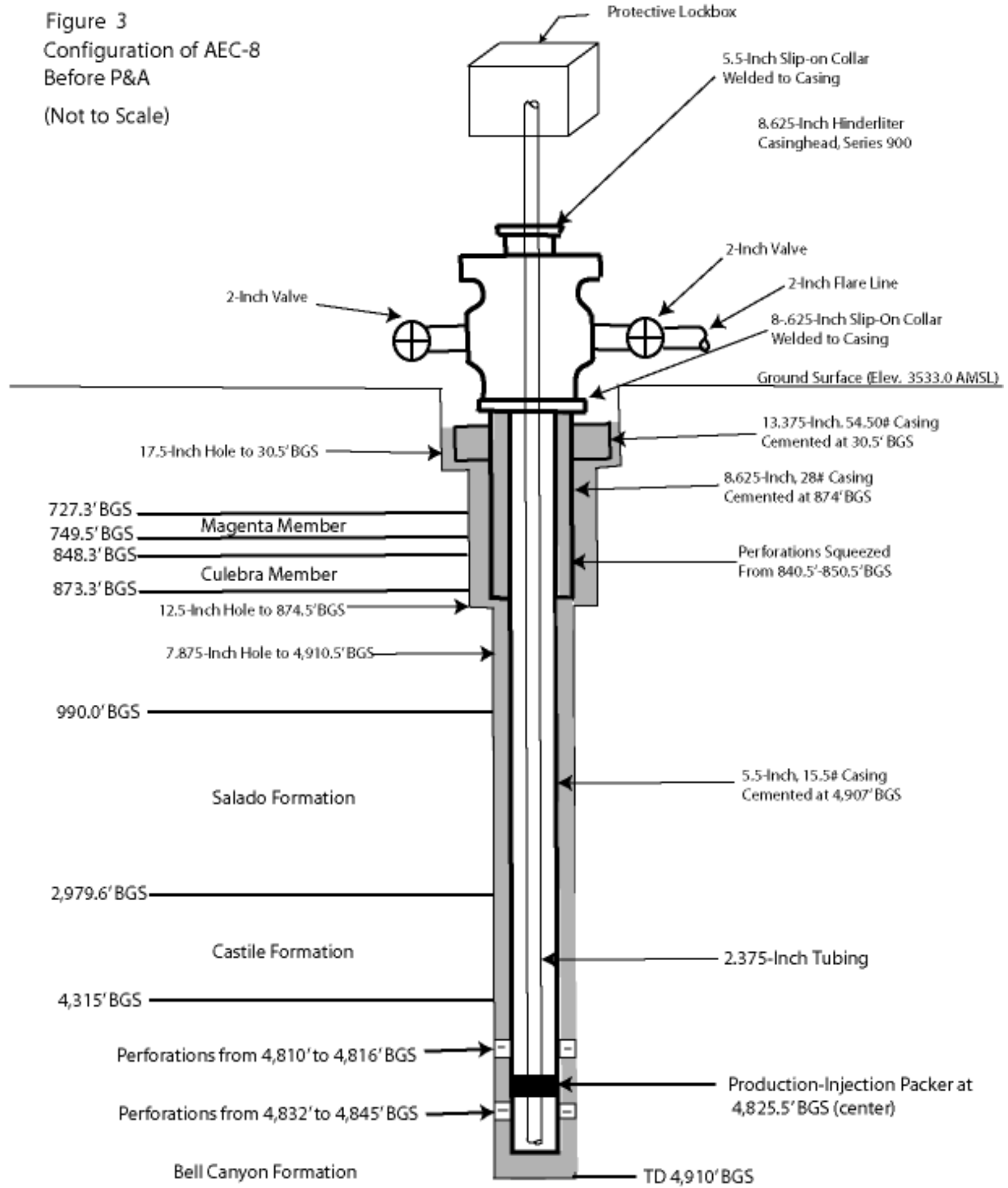


\section{Basic Data Report for Well Plugging and Abandonment and Reconfiguration Activities for Fiscal Year 2005 DOE/WIPP 05-3326}

One hundred fifty-eight (158) joints (sections) of 2.375-inch tubing were removed from the well along with the packer. In addition to the removed equipment described above, two old pressure transducers attached to the packer and the associated cable and wires for each transducer were also removed estimated at 5000 feet per transducer (Photo 5). The transducers were permanently fixed to the packer when it was installed by SNL for continuous monitoring. After removal, the transducers were returned to SNL for historic preservation. The cable and wire were transported to the dumpster located at the $\mathrm{H}-3$ well pad for future disposal.

The well was prepared for cementing after the well appurtenances were removed. Scraping was performed as described in Section 2.0 of the report to the total depth of casing, 4,907 feet bgs. The well was then circulated with fresh water until the return was clean. Upon completion of circulation, the well was cemented to the surface as described in Section 2.0 of this report. A total of 702 cubic feet of Class $C$ Neat cement slurry was used to plug the well to the surface. Upon completion of the cementing, a well monument was fixed to the well location in accordance to BLM requirements (Figure 4) (Photo 6).

\subsection{H-2 WELL PAD}

The $\mathrm{H}-2$ hydropad consisted of one well completed in the Magenta Member of the Rustler Formation ( $\mathrm{H}-2 \mathrm{~b} 1)$ and three wells completed in the Culebra Member of the Rustler Formation ( $\mathrm{H}-2 \mathrm{a}, \mathrm{H}-2 \mathrm{~b} 2$, and $\mathrm{H}-2 \mathrm{c}$ ) (Stensrud et al., 1988a). The pad now consists of one Magenta well and one Culebra well after plugging and reconfiguration efforts. This pad is located approximately 0.75 mile southwest of the center of WIPP. It is located in Section 29, Township 22 South, and Range 31 East (Figure 5).

The scope of work at this hydropad was to plug one of two wells completed in the Culebra $(\mathrm{H}-2 \mathrm{~b} 2$ or $\mathrm{H}-2 \mathrm{c})$ and plug $\mathrm{H}-2 \mathrm{a}$ because it had a pump in the bottom of the well, lost during a sampling event. In addition to the activities listed above for the $\mathrm{H}-2$ well pad, the scope of work also included plugging back well $\mathrm{H}-2 \mathrm{~b} 1$ to below the existing Magenta perforations.

\subsection{Well H-2a}

Well H-2a was originally drilled to a total depth of 563 feet bgs and cased to a depth of 511 feet bgs. The hole was later deepened to 616 feet bgs and cored to 672 feet bgs. In 1984, the hole was reentered and completed with a screen across the Culebra (Figure 6) (Stensrud et al., 1988a). During a well sampling event, a Bennett pneumatic pump and packer assembly was dropped into the well and jammed itself into the well at the bottom of the casing at a depth of 605 feet bgs. Attempts were made to retrieve the pump, but all were unsuccessful. 


\section{Basic Data Report for Well Plugging and Abandonment and Reconfiguration Activities for Fiscal Year 2005 DOE/WIPP 05-3326}

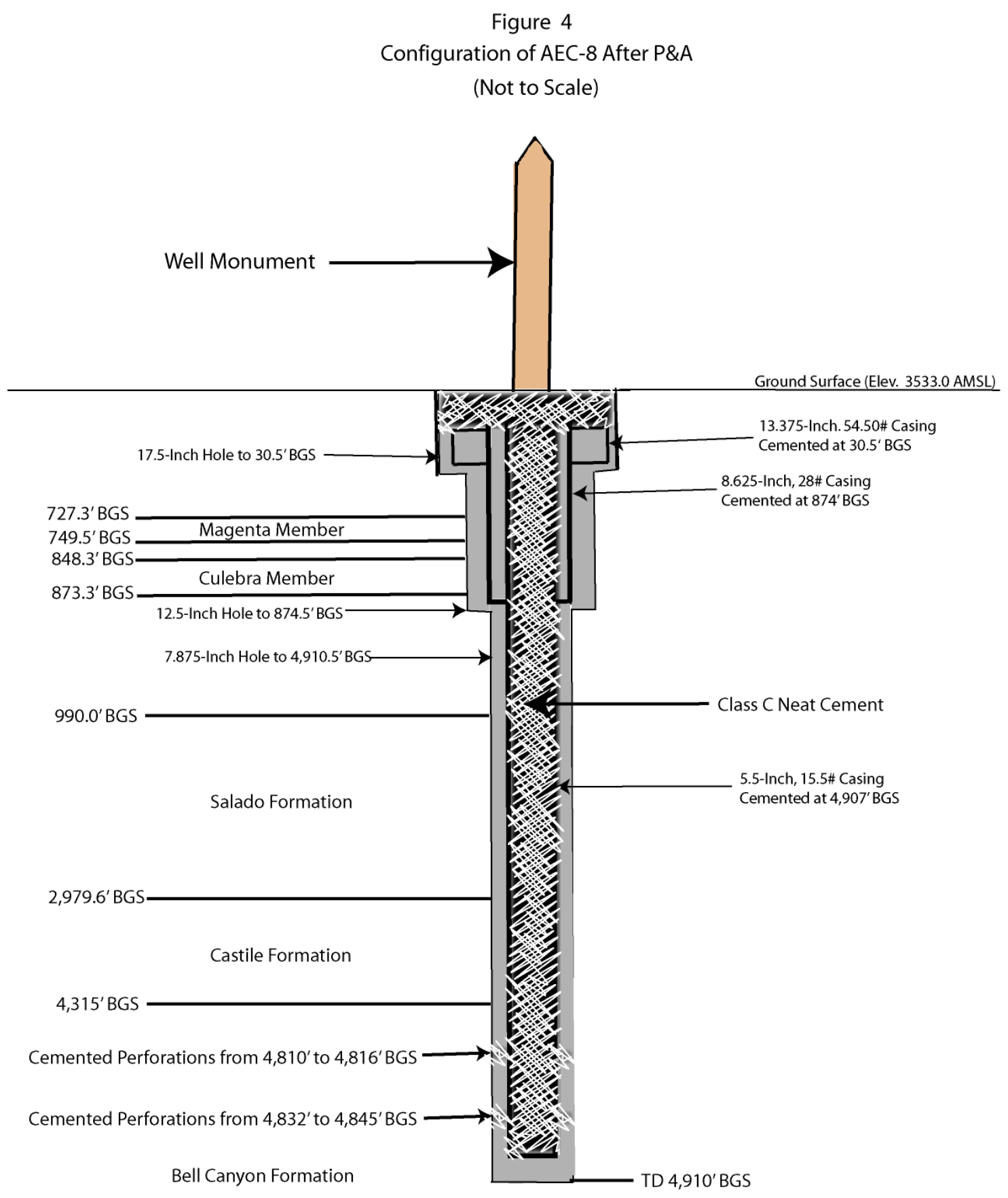


Basic Data Report for Well Plugging and Abandonment and Reconfiguration Activities for Fiscal Year 2005

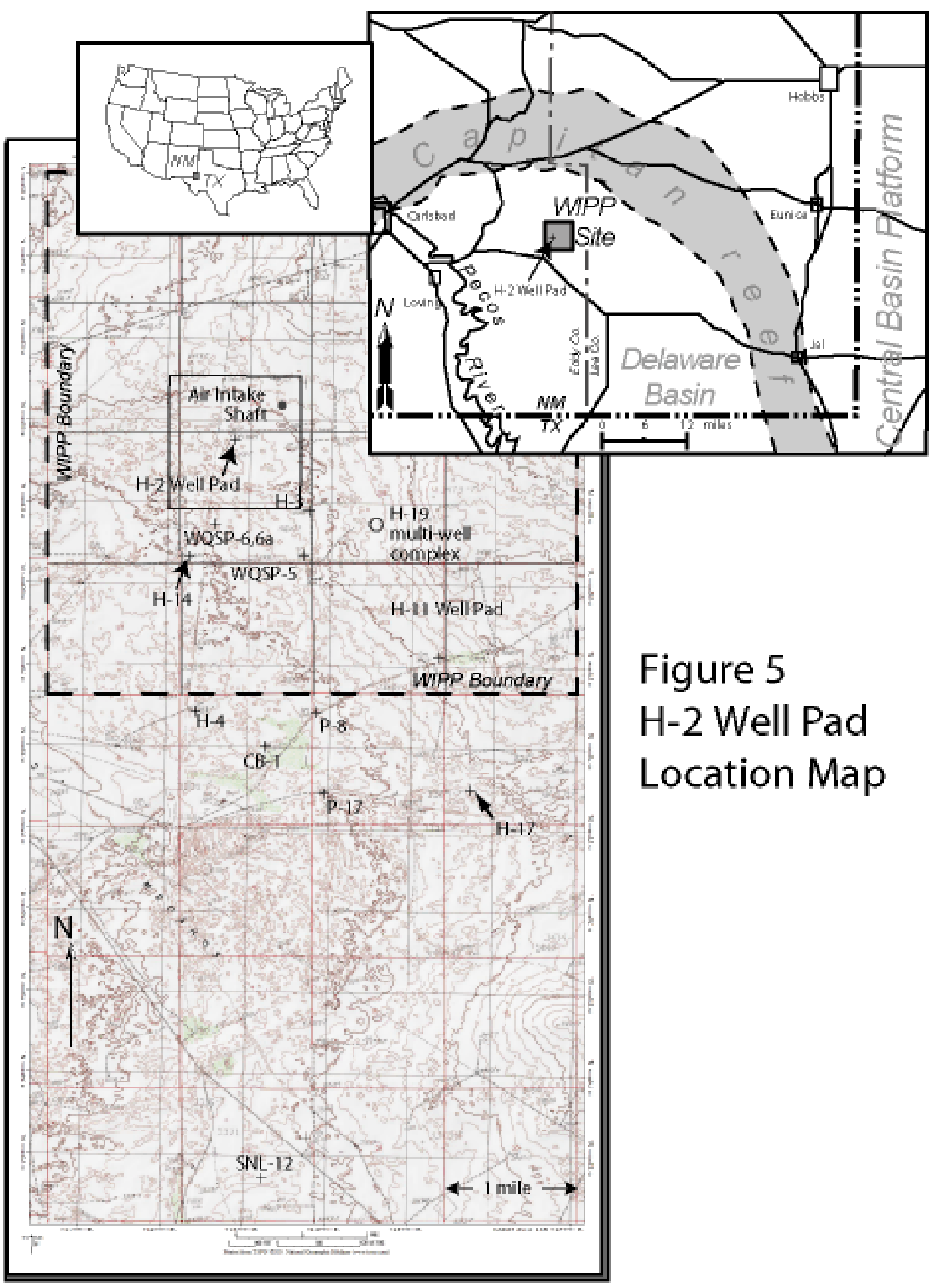




\title{
Basic Data Report for Well Plugging and Abandonment and Reconfiguration Activities for Fiscal Year 2005 DOE/WIPP 05-3326
}

\author{
Figure 6 \\ Construction of Well H-2a Before P\&A \\ (Not to Scale)
}

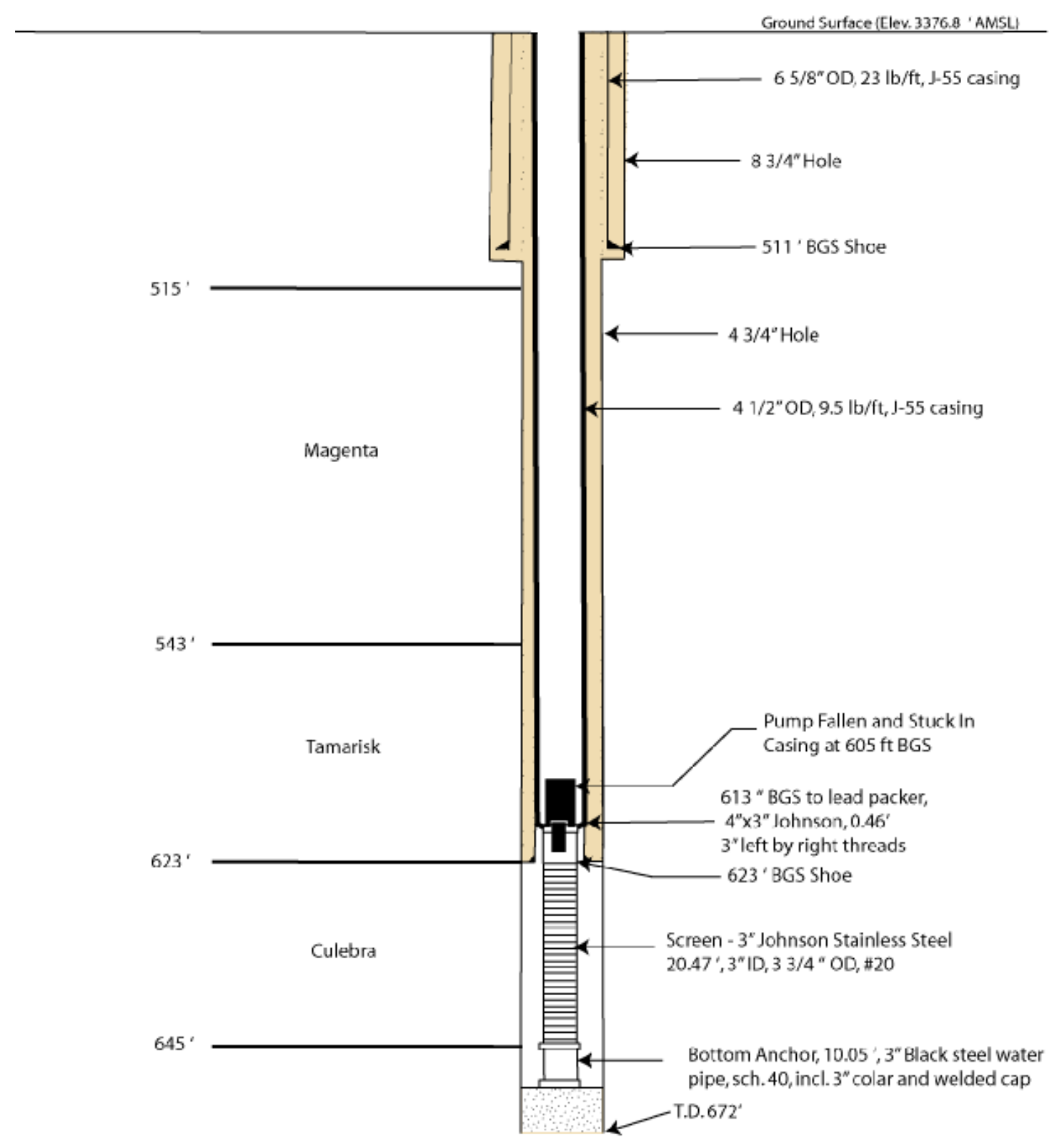




\section{Basic Data Report for Well Plugging and Abandonment and Reconfiguration Activities for Fiscal Year 2005 \\ DOE/WIPP 05-3326}

The NMOSE was consulted regarding the condition of this hole before attempting to retrieve the lost pump in the well. Through these discussions, the NMOSE approved leaving the pump in the well and cementing it in as long as the pump is driven into the well as far as possible. After this change in scope, the well was scraped and circulated as described in Section 2.0 of this report. Following casing preparation, the pump was driven from 605 feet bgs to a depth of 610 feet bgs, gaining 5 feet. The pump was driven into the lead packer and screen (Figure 7).

Upon completion of circulation, the well was cemented to the surface as described in Section 2.0 of this report. A total of 81 cubic feet of Class $C$ Neat cement slurry was used to plug the well to the surface. After cementing, a well monument was fixed to the well location in accordance to BLM requirements (Figure 7). Work on this well concluded on April 7, 2005, one day after starting.

\subsection{Well H-2b1}

Well $\mathrm{H}-2 \mathrm{~b} 1$ was being used to monitor hydrostatic head in the Magenta Member of the Rustler Formation. Well H-2b1 was drilled in February 1977 to a total depth of 661 feet bgs and cased with 6.625-inch casing to the top of the Culebra Member of the Rustler Formation at a depth of 609 feet bgs. The interval between 510 and 538 feet was later shot-perforated to access the Magenta Member of the Rustler Formation. A packer was set at a depth of 578 feet bgs to isolate the Culebra (Figure 8) (Stensrud et al., 1988a).

The goal for well $\mathrm{H}-2 \mathrm{~b} 1$ was to remove the packer, plug the well back to below the Magenta perforations, and use it as only a Magenta monitoring well. Work on this well began on April 12, 2005, and concluded on April 16, 2005. The work over activities began with scraping the well casing to the top of the packer and circulating the debris out of the well. A J-tool was used for the removal of the packer as described in Section 2.0 of this report. The packer was not removed. After latching onto the packer with the J-tool, the drill rig applied pressure to pull it out of the well. After several minutes of applied pressure, the packer separated where the J-tool attaches to the packer lugs, on top of the mandrel (Photos 7 and 8). After inspection of the packer mandrel head, it was apparent that metal fatigue was the reason for the failure.

After attempting removal with a J-tool, the decision was made to remove the packer using an overshot and grapple tool since the lugs were broken off the mandrel. Using the overshot was successful at moving the top of the packer from 589 feet bgs to 446 feet bgs before getting stuck. The packer would not move at all beyond this point after several attempts. Contact was made with the NMOSE to authorize driving the packer as deep as possible and cementing it in the well. The NMOSE did authorize cementing the packer into the well as long as the packer was driven as deep as possible into the well. 


\section{Basic Data Report for Well Plugging and Abandonment and Reconfiguration Activities for Fiscal Year 2005

Figure 7

Construction of Well H-2a After P\&A

(Not to Scale)

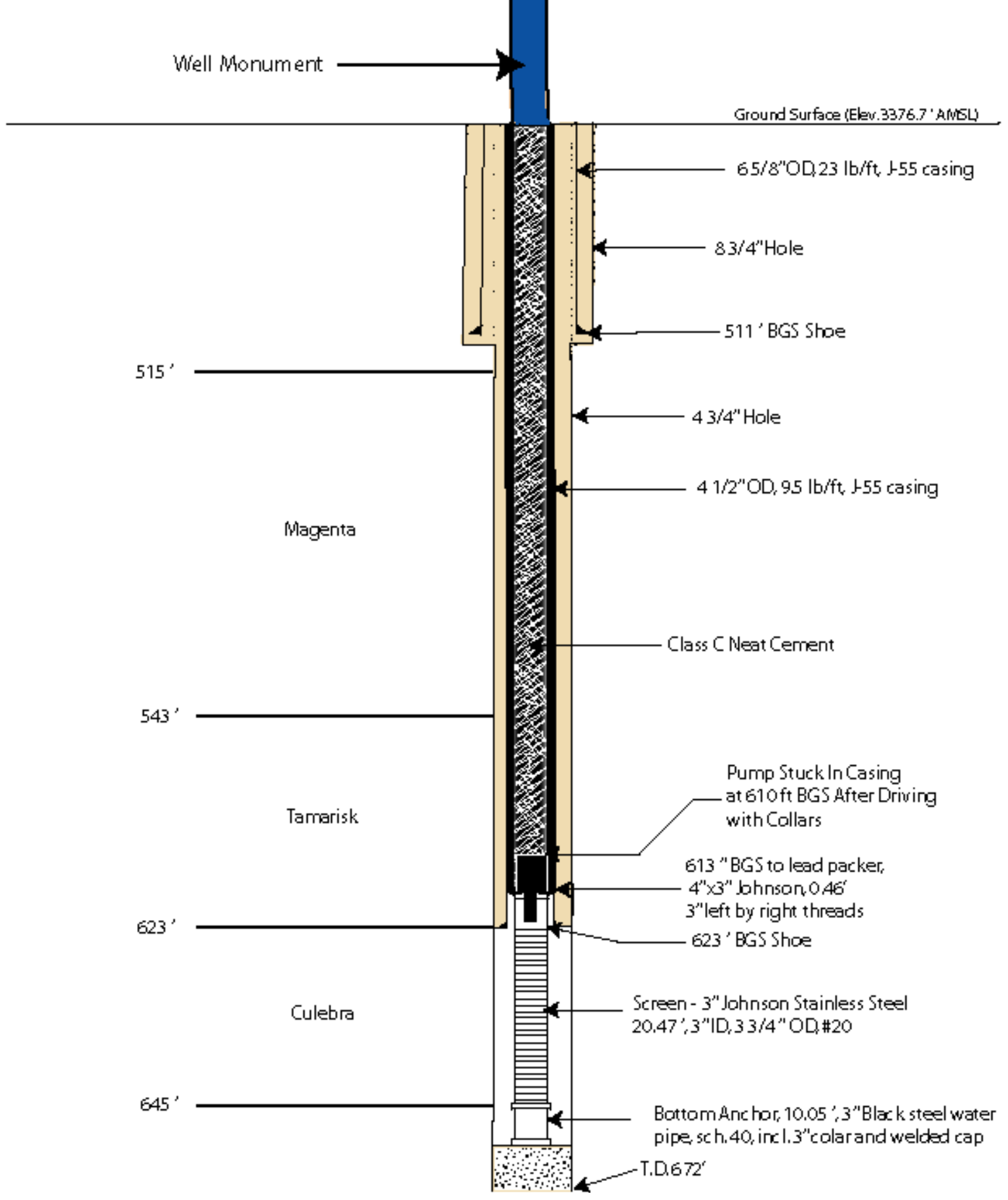




\section{Basic Data Report for Well Plugging and Abandonment and Reconfiguration Activities for Fiscal Year 2005 DOE/WIPP 05-3326}

Figure 8

Construction of Well $\mathrm{H}-2 \mathrm{~b}$ 1

Before Reconfiguration

(Not to Scale)

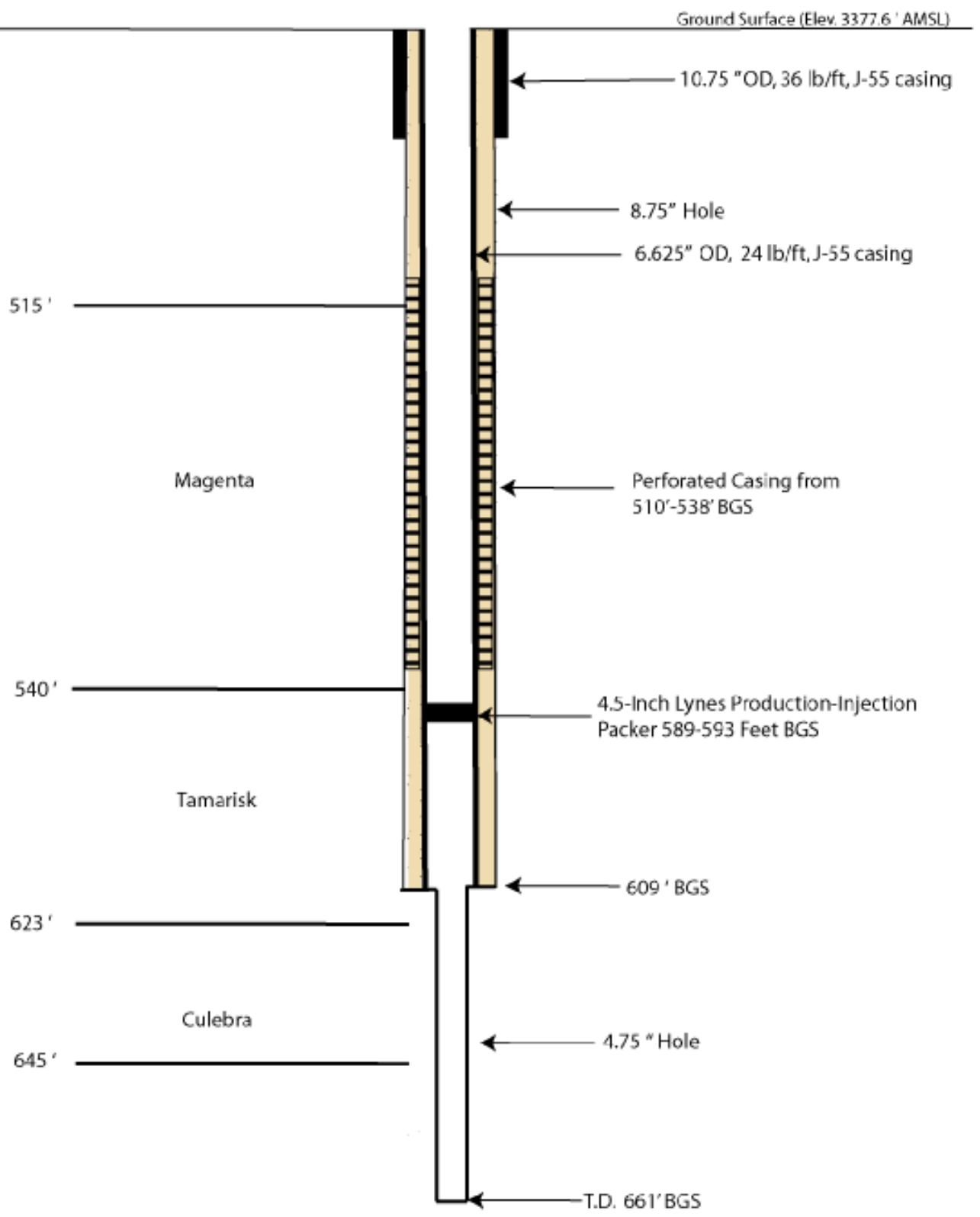




\section{Basic Data Report for Well Plugging and Abandonment and Reconfiguration Activities for Fiscal Year 2005 \\ DOE/WIPP 05-3326}

Stacked drill collars were used at the end of the tremmie tubing to drive the packer back down the hole. Ten 4.75-inch collars were used to drive the packer to a final depth of 603 feet bgs, measuring to the top of the remaining mandrel. This effectively provided a seal above the Culebra for the cement emplacement. After driving with the collars, the remaining casing was scraped and the well was circulated preparing the well for cement. The well was cemented to a depth of 558 feet bgs using 10.5 cubic feet of Class $\mathrm{C}$ Neat cement slurry. This elevation is 20 feet below the Magenta perforations allowing future Magenta monitoring at this location (Figure 9).

\subsection{Well $\mathrm{H}-2 \mathrm{~b} 2$ and Well $\mathrm{H}-2 \mathrm{c}$}

The goal between these two wells was first to determine which well was in better condition and keep the best well for future monitoring, while plugging the worst well and removing it from the monitoring network. Well $\mathrm{H}-2 \mathrm{~b} 2$ was drilled in 1982 to a depth of 660 feet bgs for monitoring the Culebra. In 1984, due to hole instability, a well screen was placed across the Culebra to keep the unit open to monitoring. Well $\mathrm{H}-2 \mathrm{c}$ was originally drilled in 1977 to a depth of 795 feet bgs, and cased to the top of the Rustler/Salado contact at 792 feet bgs with 6.625-inch OD, J-55 casing. A 5.375-inch OD packer was set at 663 feet bgs to isolate the Culebra. The casing was perforated across the Culebra interval (Figure 10) (Stensrud et al., 1988a).

To determine which well was the better of the two wells, borehole geophysical techniques were used. Each well was scraped and circulated on April 17, 2005. Following well preparation, each well was evaluated using a cement bond log and casing corrosion log. Based on these logs and collaboration with SNL, it was determined that well $\mathrm{H}-2 \mathrm{c}$ was in worse condition and required plugging. Well $\mathrm{H}-2 \mathrm{~b} 2$ was retained as a Culebra monitoring well, leaving the $\mathrm{H}-2$ well pad with one Culebra and one Magenta well for monitoring.

Prior to scraping and circulating well $\mathrm{H}-2 \mathrm{c}$, the packer set at 663 feet bgs was removed using a J-tool. The packer was removed without incident and, following evaluation of the geophysics, this well was plugged using 162 cubic feet of Class $C$ Neat cement slurry. Upon completion of the cementing, a well monument was fixed to the well location in accordance to BLM requirements (Figure 11).

\subsection{WELL H-14}

Well $\mathrm{H}-14$ is located in eastern Eddy County, New Mexico in the southwest quarter, Section 29, Township 22 South, Range 31 East (Figure 12). The drilling of the borehole was performed during September and October 1986 to a depth of 589 feet. After drilling, 5.5-inch casing was set and cemented from 532 feet bgs to the surface. A 4.5-inch hole was then cored through the Culebra to 574 feet bgs. The open portion of the well was then reamed to a 4.75-inch diameter and deepened to a final depth of 589 feet bgs (Stensrud et al., 1987). 


\section{Basic Data Report for Well Plugging and Abandonment and Reconfiguration Activities for Fiscal Year 2005 DOE/WIPP 05-3326}

Figure 9 Construction of Well $\mathrm{H}-2 \mathrm{~b}$ 1 After Reconfiguration

(Not to Scale)

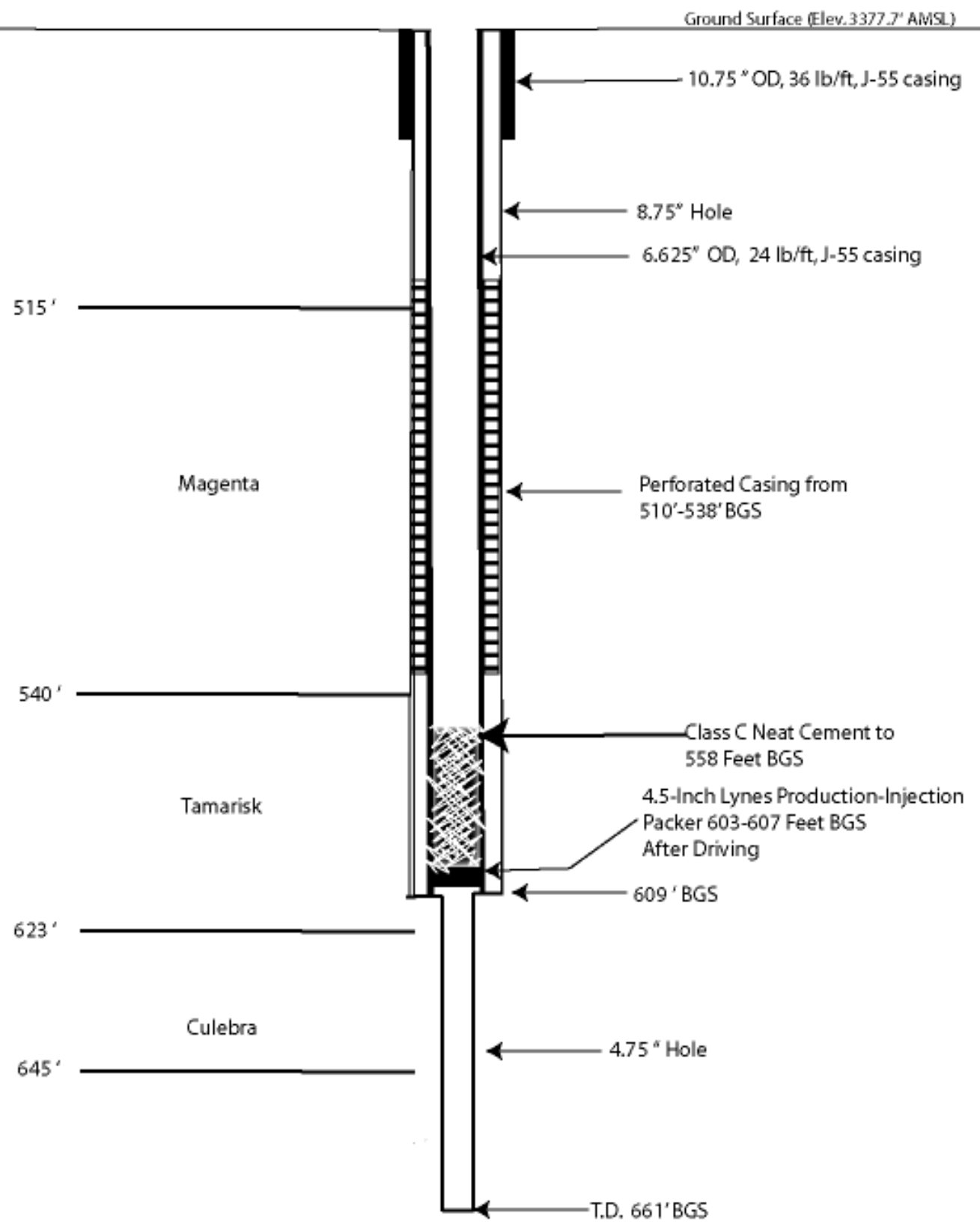


Basic Data Report for Well Plugging and Abandonment and

Reconfiguration Activities for Fiscal Year 2005

DOE/WIPP 05-3326

Figure 10

Construction of Well H-2c Before P\&A

(Not to Scale)

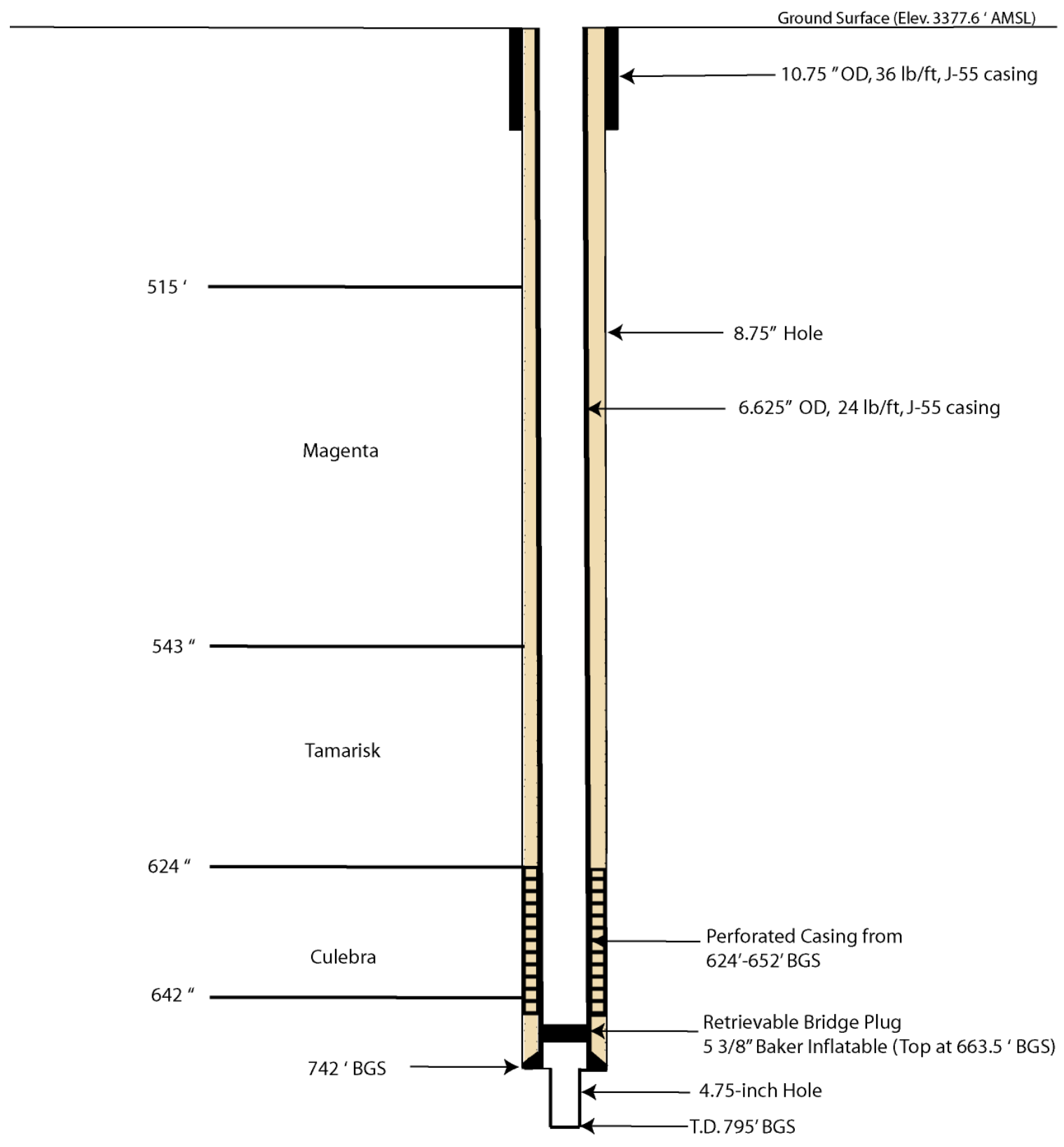




\section{Basic Data Report for Well Plugging and Abandonment and Reconfiguration Activities for Fiscal Year 2005

Figure 11

Construction of Well H-2c After P\&A

(Not to Scale)

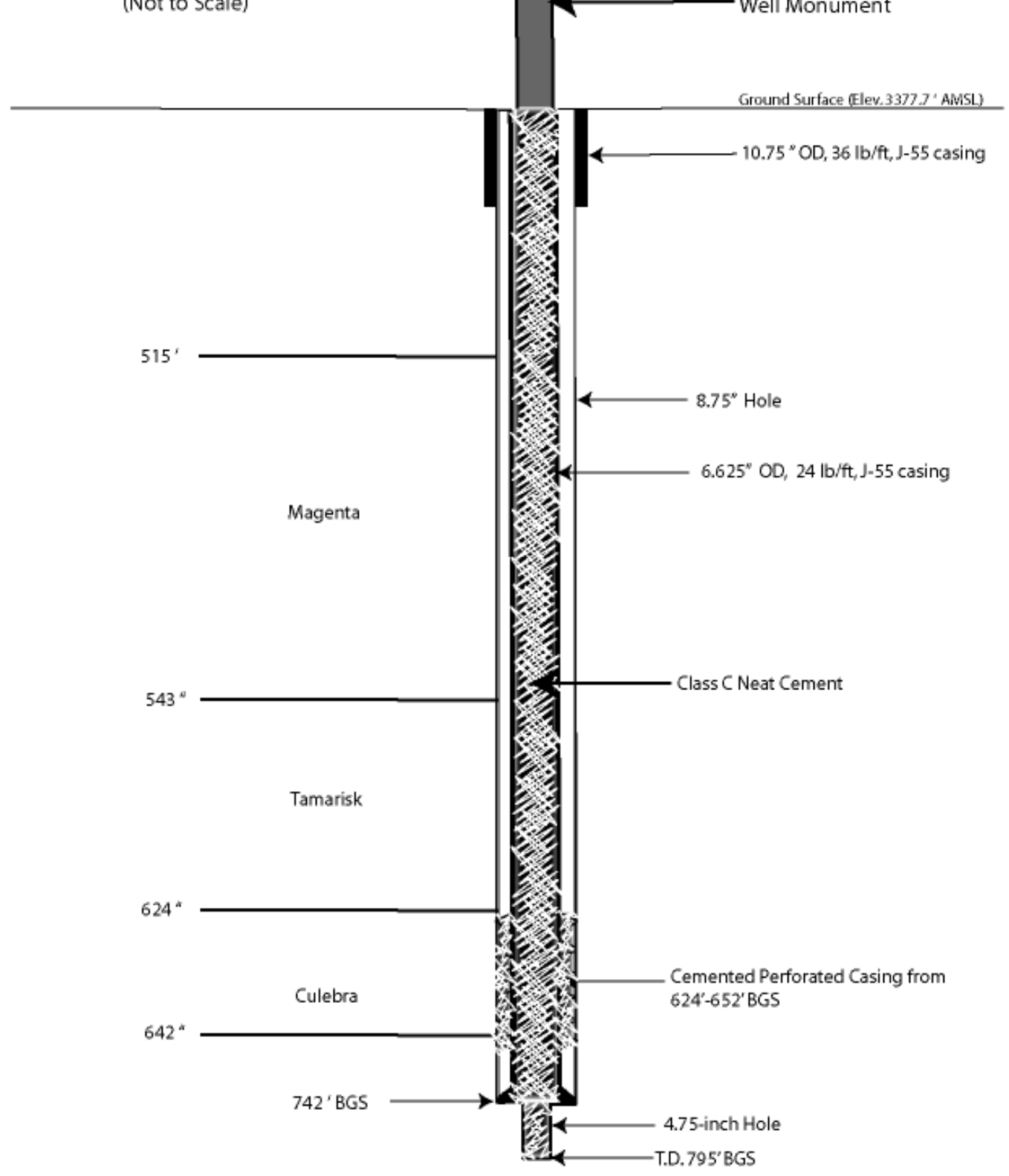


Basic Data Report for Well Plugging and Abandonment and Reconfiguration Activities for Fiscal Year 2005

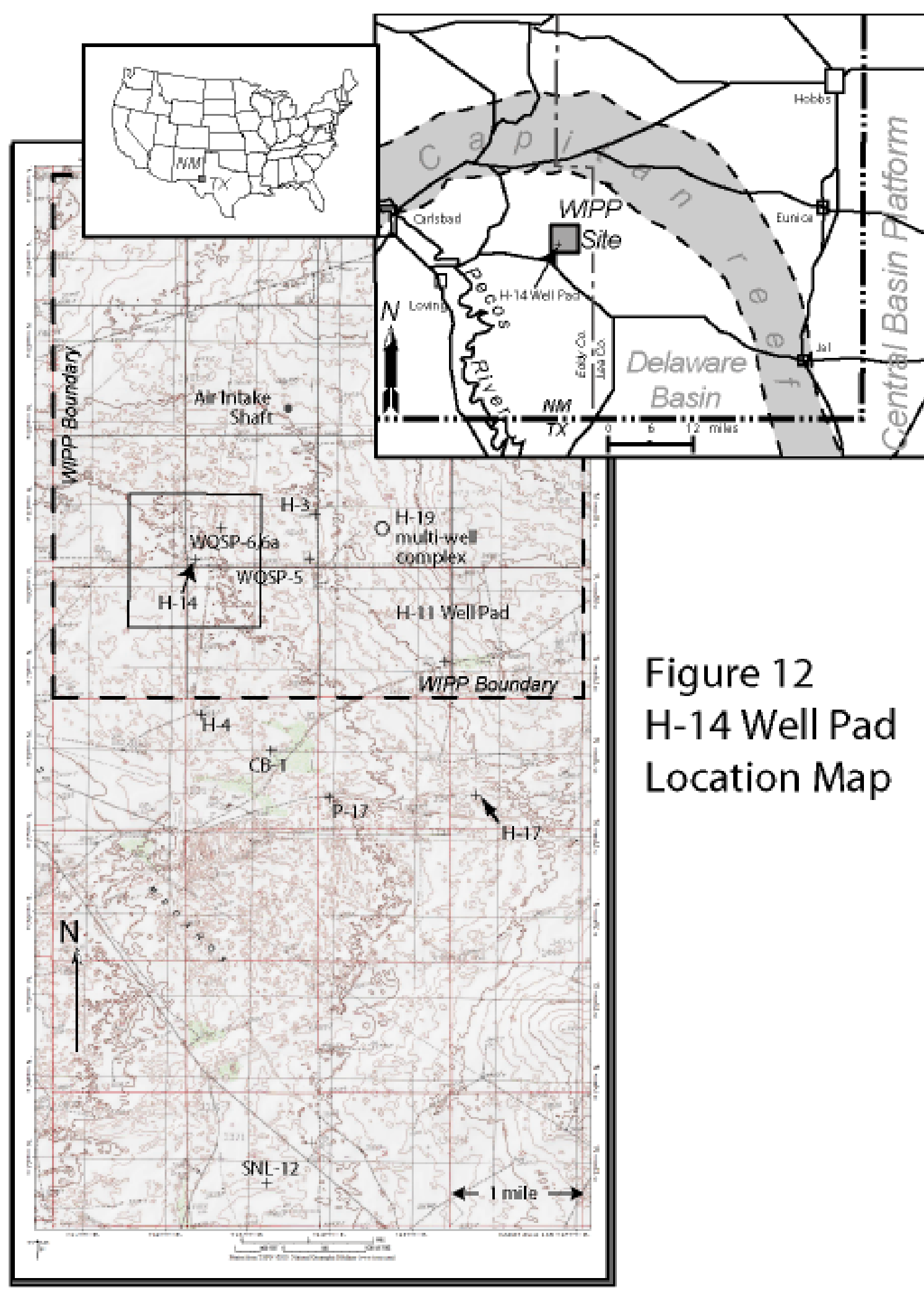




\section{Basic Data Report for Well Plugging and Abandonment and Reconfiguration Activities for Fiscal Year 2005 \\ DOE/WIPP 05-3326}

In March 2001, the well was fitted with an inflatable bridge plug (PIP) at a depth of 465.78 feet bgs, just below the Magenta Member. Following the installation of the bridge plug, the well was perforated at the Magenta interval from 428 to 455 feet bgs (Figure 13). Well H-14 was used to monitor hydrostatic head in the Magenta Member of the Rustler Formation in this configuration. The objective under this program was to reconfigure well $\mathrm{H}-14$ as a Magenta-only monitor well.

Reconfiguration of well H-14 took place between April 21, 2005, and April 27, 2005. The casing was scraped and the well circulated to the top of the packer. Several unsuccessful attempts were made to retrieve the packer using a J-tool and two sizes of overshot and grapple tools. After the attempts at removing the packer with the standard tools, a decision was made to use a spear to fish out the packer (Photo 9).

The packer was removed with the spear without any problems. After the packer was removed, it was discovered that the packer was an odd size and not configured for removal with the tools being used. Following packer removal, the remainder of the casing was scraped to a depth of 532 feet bgs and the well circulated. After circulation, the well was reconfigured by cementing to a depth of 468 feet bgs, 20 feet below the Magenta perforations, using 23.75 cubic feet of Class C Neat cement slurry (Figure 14).

\subsection{WELL H-18}

Well H-18 is located in Eddy County, New Mexico in Section 20, Township 22 South, Range 31 East (Figure 15). Well $\mathrm{H}-18$ was drilled in October 1987 to define hydrologic properties of the Culebra. After being cored and reamed to a 9.625-inch diameter hole to 674 feet bgs, 7 -inch casing was installed and cemented to 673 feet bgs. The hole was then cored and reamed to 4.75 -inch diameter to a depth of $714.1 \mathrm{feet}$ bgs. After further borehole testing, the hole was deepened and reamed to a total depth of 840 feet bgs. A cement plug was placed in well $\mathrm{H}-18$ from the total depth to 766 feet bgs (Figure 16) (Stensrud et al., 1988b).

In March 2001, the well was fitted with an inflatable bridge plug (PIP) at a depth of 613.08 feet bgs, just below the Magenta Member. Following the installation of the bridge plug, the well was perforated at the Magenta interval from 575 to 601 feet bgs (Figure 16).

Well $\mathrm{H}-18$ was a dual-completion well used to monitor hydrostatic head in the Magenta Member of the Rustler Formation. The objective under the FY 2005 program was to reconfigure well $\mathrm{H}-18$ as a Magenta-only monitor well.

Reconfiguration of well H-18 took place between April 27, 2005, and April 30, 2005. The casing was scraped and the well circulated to the top of the packer. Several attempts were made to retrieve the packer using a J-tool. After attempting to remove the packer with a J-tool and using knowledge gained at well $\mathrm{H}-14$, a decision was made to use a spear to fish out the packer (Photo 10). 


\section{Basic Data Report for Well Plugging and Abandonment and Reconfiguration Activities for Fiscal Year 2005 DOE/WIPP 05-3326}

Figure 13

Construction of Well H-14 Before Reconfiguration

(Not to Scale)

Ground Surface (Elev.3345.6' AhSLL)

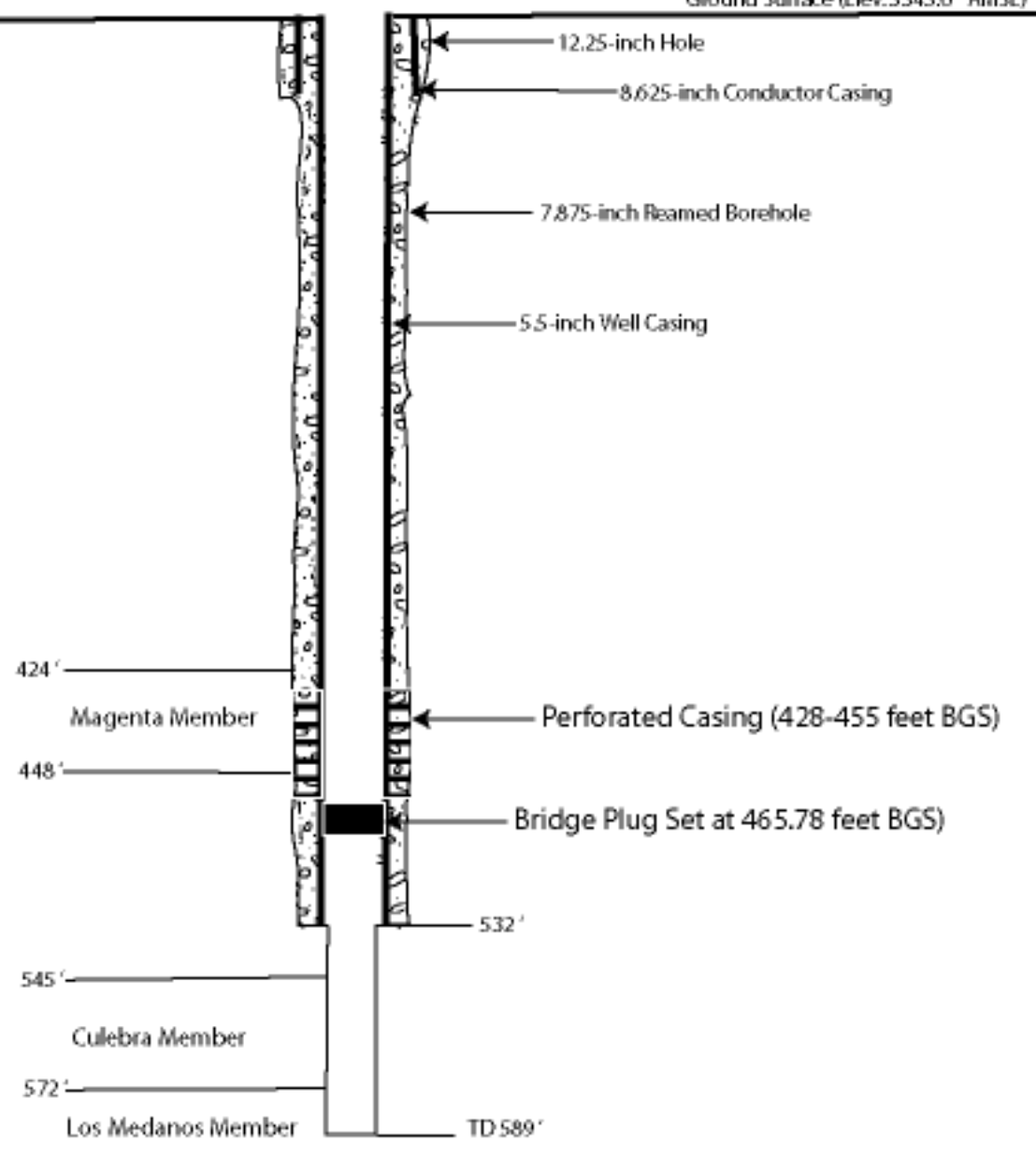




\section{Basic Data Report for Well Plugging and Abandonment and Reconfiguration Activities for Fiscal Year 2005

Figure 14

Construction of Well H-14 After Reconfiguration

(Not to Scale)

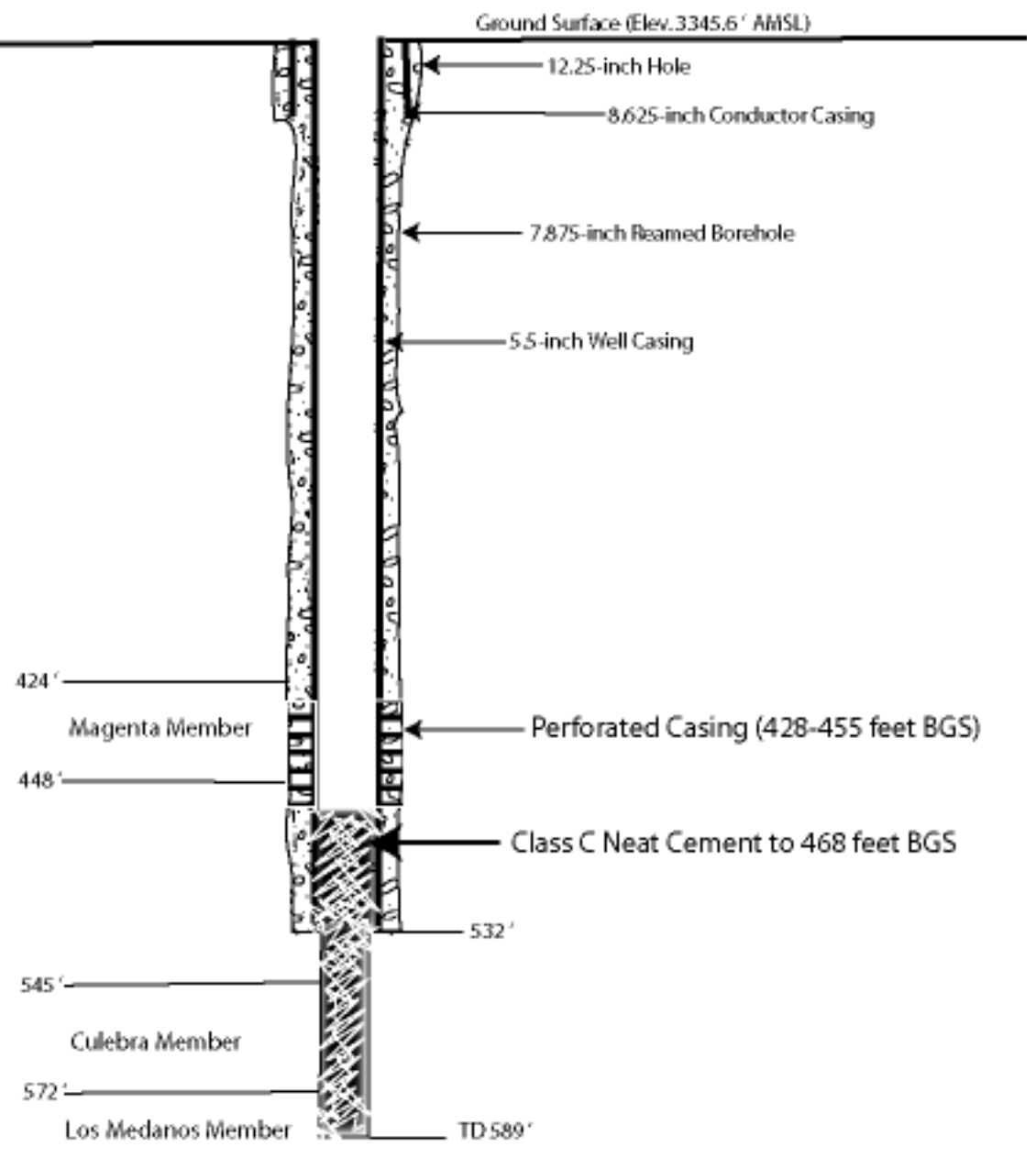


Basic Data Report for Well Plugging and Abandonment and Reconfiguration Activities for Fiscal Year 2005

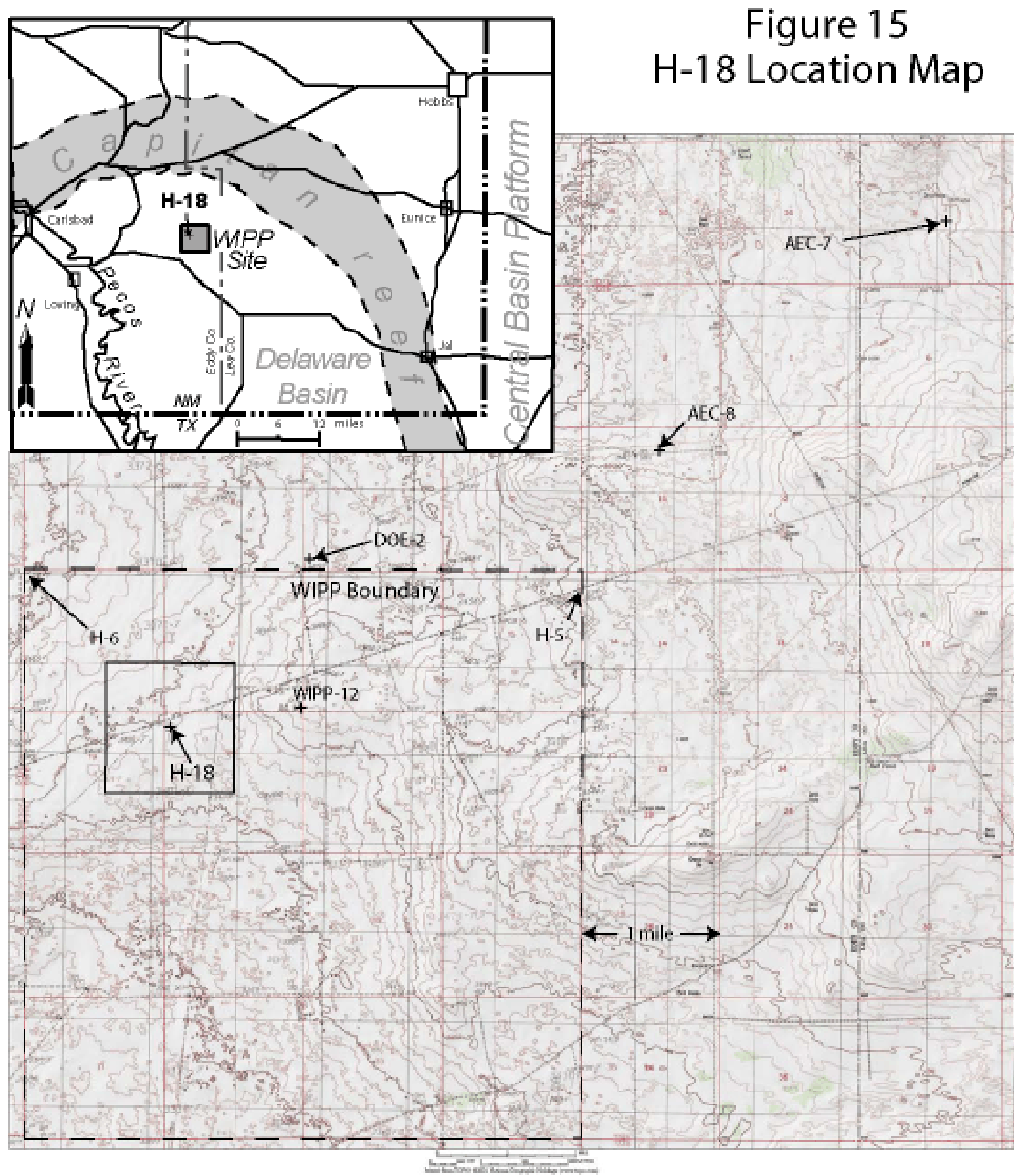




\section{Basic Data Report for Well Plugging and Abandonment and Reconfiguration Activities for Fiscal Year 2005

Figure 16

Construction of Well H-18

Before Reconfiguration

(Not to Scale)

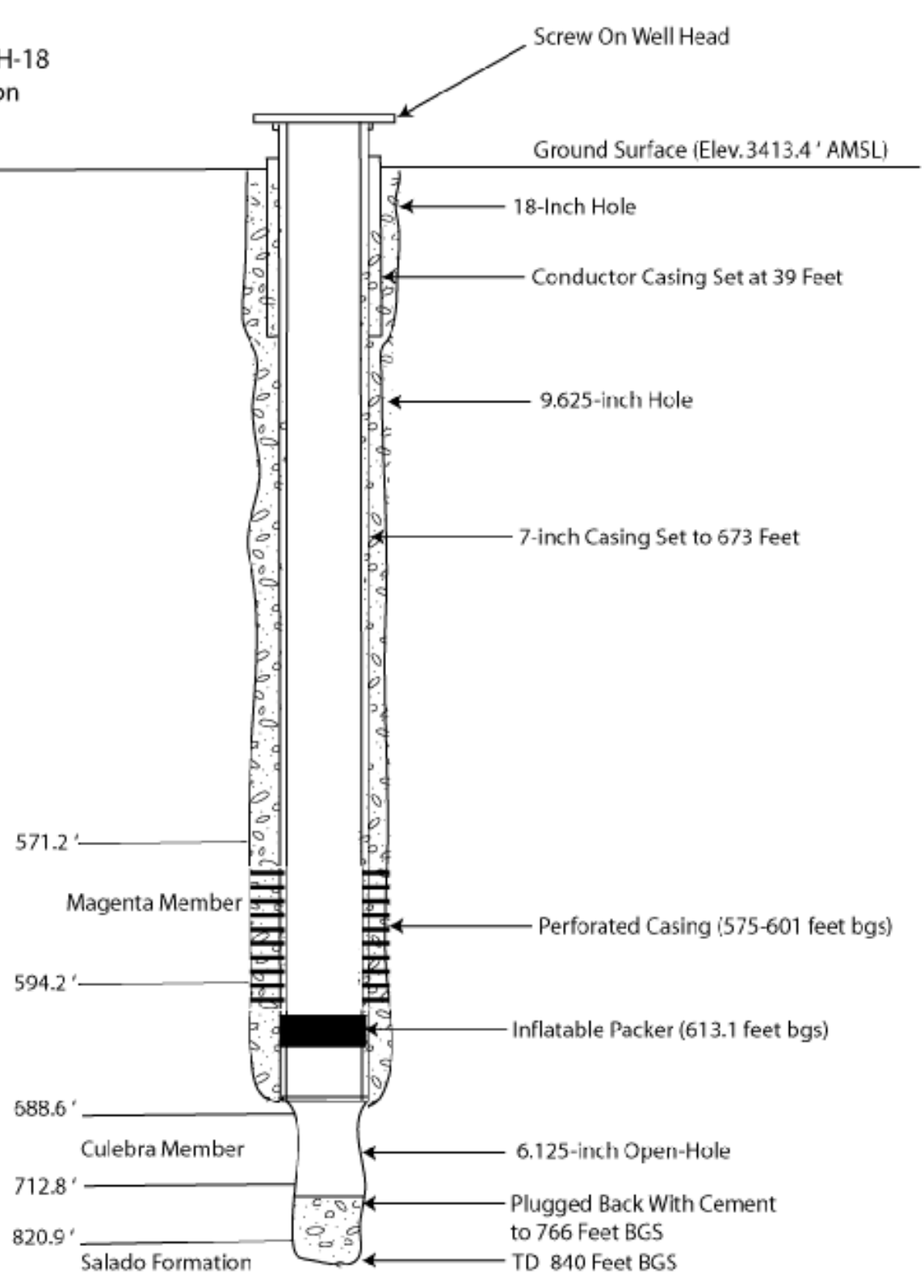




\section{Basic Data Report for Well Plugging and Abandonment and Reconfiguration Activities for Fiscal Year 2005 \\ DOE/WIPP 05-3326}

The packer was removed with the spear without any problems. Following packer removal, the remainder of the casing was scraped to a depth of 673 feet bgs and the well circulated. After circulation, the well was reconfigured by cementing the well to a depth of 615 feet bgs with 40.5 cubic feet Class C Neat cement slurry (Figure 17).

\subsection{WELL H-4C}

Well H-4c is located in eastern Eddy County, New Mexico in the southwest quarter, Section 32, Township 22 South, Range 31 East (Figure 18). Well H-4c was originally drilled in 1978 to test and monitor the Rustler/Salado contact. A 7.875-inch borehole was drilled to a depth of 610 feet bgs and completed with 5.5-inch casing to a depth of 610 feet bgs. The casing was then cemented to the surface. The borehole was then cored at a diameter of 4.75 -inches from 610 feet to 661 feet bgs, forty feet into the Salado Formation. In February 1981, a retrievable bridge plug was set in the casing at a depth of 530 feet bgs. The casing was then shot-perforated from 494 to 520 feet bgs to access the Culebra (Stensrud et al., 1987).

In 1986, the well was reentered to complete a monitoring interval across the Magenta Member of the Rustler Formation. First, a 4.25-inch Baker Production Bridge Plug was installed in the well at a depth of 435.07 feet bgs to the top of the packer. Following the packer installation, the Magenta dolomite interval was perforated from 373 to 399 feet bgs (Figure 19).

Well $\mathrm{H}-4 \mathrm{c}$ was a dual-completion well used to monitor hydrostatic head in the Magenta Member of the Rustler Formation. The objective under this program was to reconfigure well $\mathrm{H}-4 \mathrm{c}$ as a single-completion Magenta-only monitor well. At the time of reconfiguration, this well was completed with two packers used to separate water-bearing zones.

The first task was to remove the upper packer by scraping and circulating down to the top of the mandrel. Once the initial scraping was accomplished, the packer was ready for removal. First a J-tool was used to remove the packer. This was successful until the packer reached a depth of 120 feet bgs, where the packer got stuck in the well. Multiple tools were tried in sequence for an attempted retrieval. At this depth, significant pressure was applied by the drilling rig to extract the packer. Rig pressure was not enough to move the packer. In an attempt to move the packer past this point, a bumper sub with hydraulic jars and drill collars were used to "jerk" the packer from this static position. Using this set up, the packer moved a small amount before it separated at the element (Photos 11 and 12).

An attempt was made to drill the packer element and mandrel assembly to loosen it from the well, which was not successful. At this point, the NMOSE was consulted and suggested that the packer be driven to the bottom of the well, on top of the lower packer. To do this, 18 drill collars and a bumper sub were used increasing the string weight of the rig to 17,000 pounds. The upper packer was then driven to a depth of 513.5 feet bgs, in the lower portion of the Culebra perforations. 


\section{Basic Data Report for Well Plugging and Abandonment and Reconfiguration Activities for Fiscal Year 2005

Figure 17

Construction of Well H-18

After Reconfiguration

(Not to Scale)

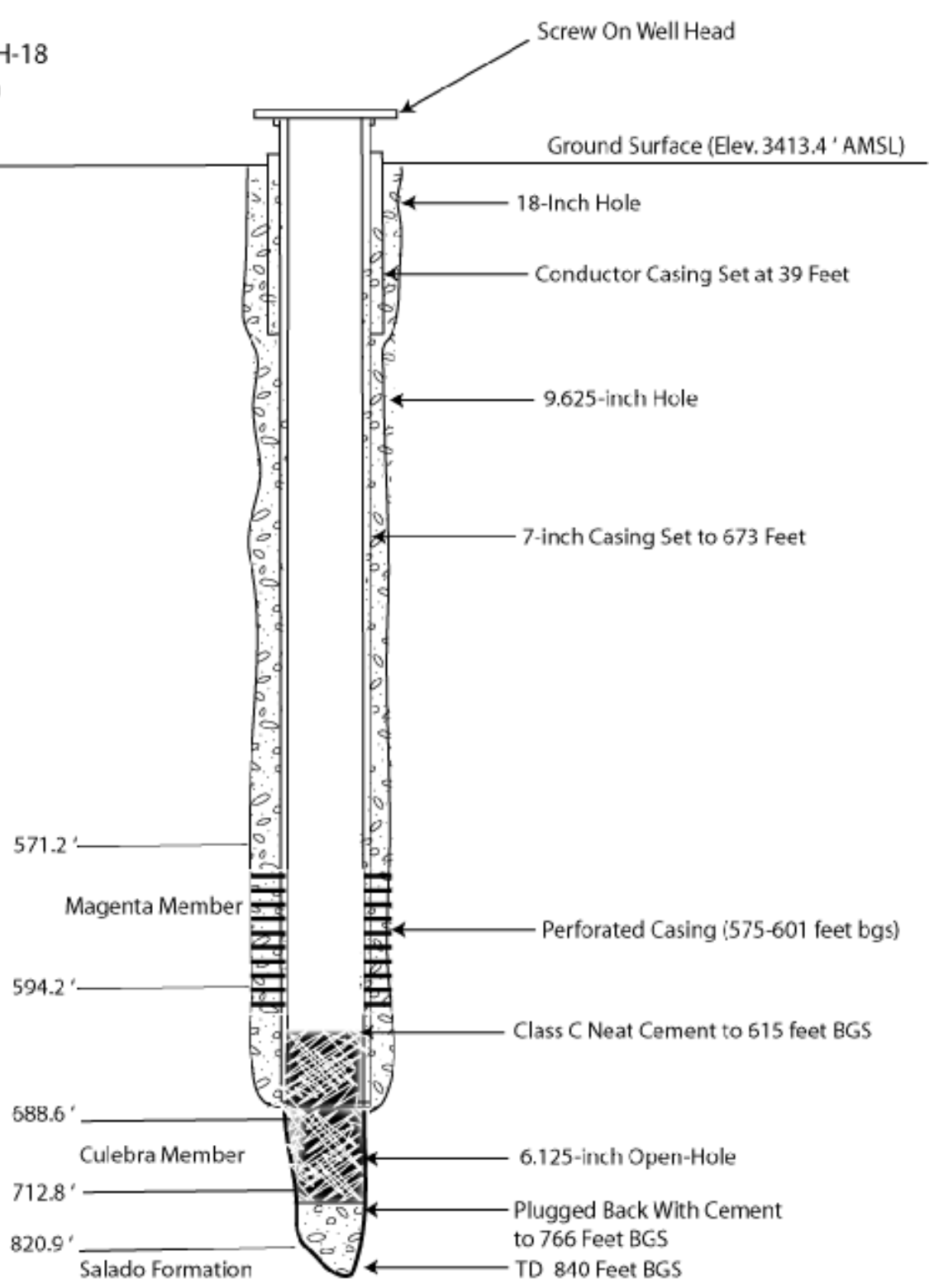


Basic Data Report for Well Plugging and Abandonment and Reconfiguration Activities for Fiscal Year 2005

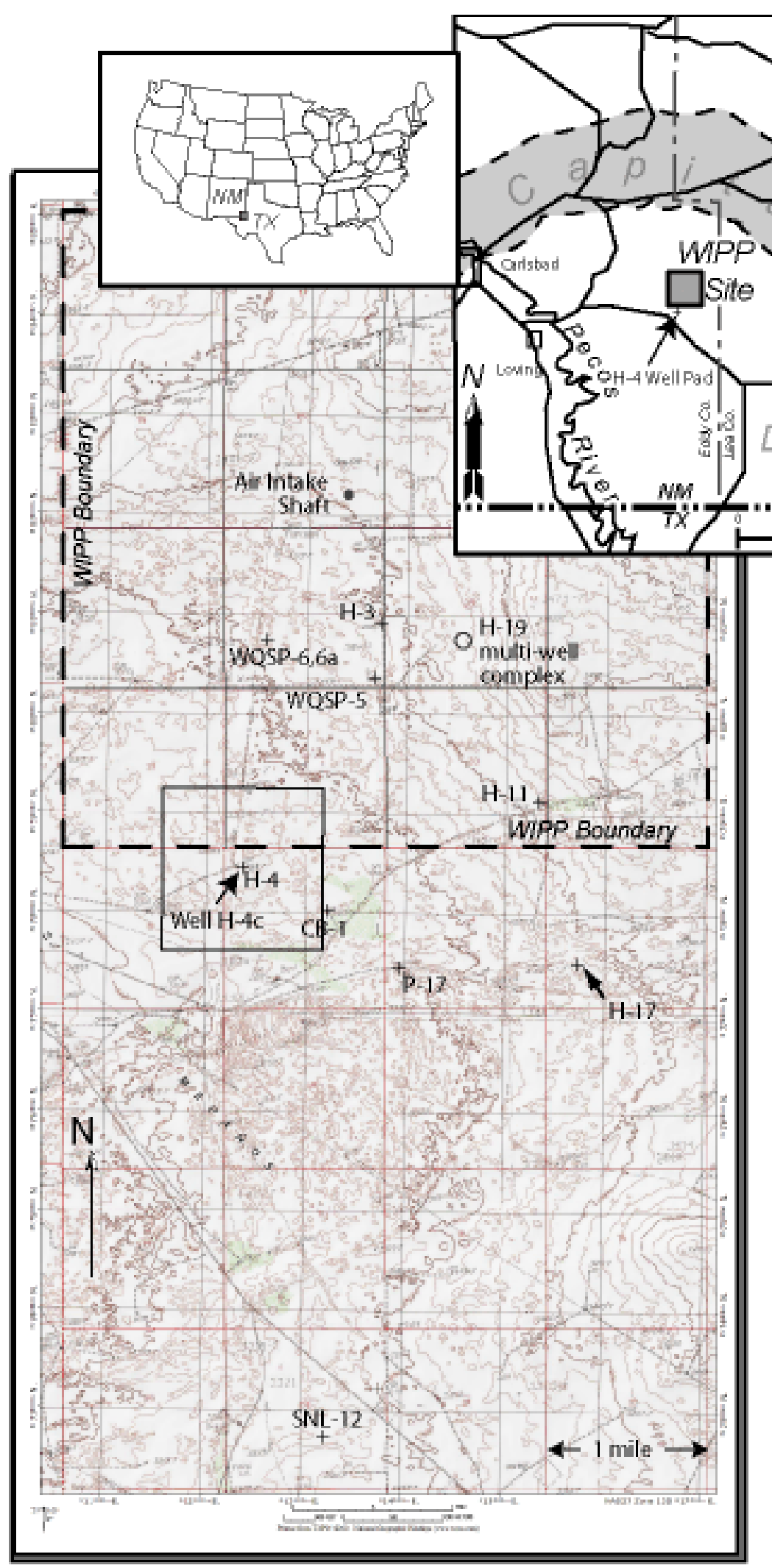

Figure 18

H-4 Well Pad

Location Map 


\section{Basic Data Report for Well Plugging and Abandonment and Reconfiguration Activities for Fiscal Year 2005

Figure 19

Construction of Well $\mathrm{H}-4 \mathrm{C}$

Before Reconfiguration

(Not to Scale)

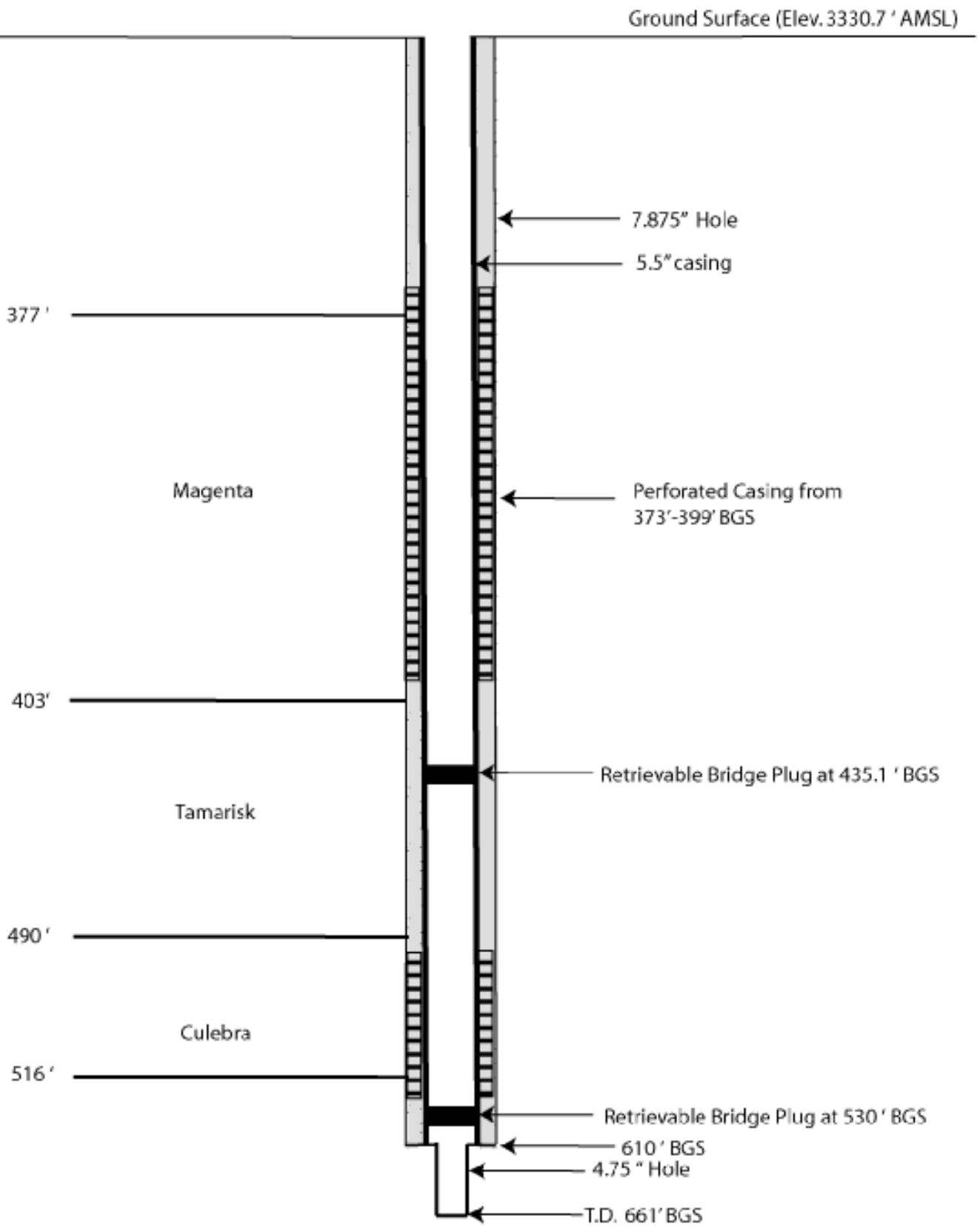




\section{Basic Data Report for Well Plugging and Abandonment and Reconfiguration Activities for Fiscal Year 2005 DOE/WIPP 05-3326}

The well was scraped from 435 feet bgs to the top of the upper packer followed by well circulation. After circulation, the well was cemented from total depth to a depth of 415 feet bgs with 19 cubic feet of Class C Neat cement slurry (Figure 20).

\subsection{WELL H-7B2}

This well is located approximately six miles southwest of the center of the WIPP site in Section 14, Township 23 South, and Range 30 East (Figure 21). The configuration of the $\mathrm{H}-7$ hydropad consisted of one well completed in the Magenta Member of the Rustler Formation ( $\mathrm{H}-7 \mathrm{a})$ and three wells completed in the Culebra Member of the Rustler Formation (H-7b, H-7b2, and H-7c) (SNL and Intera Technologies 1986).

The original scope of work at this hydropad was to plug two wells completed in the Culebra $(\mathrm{H}-7 \mathrm{~b} 2$ and $\mathrm{H}-7 \mathrm{c})$. During the process, the BLM requested transfer of well $\mathrm{H}-7 \mathrm{c}$ to their ownership for future livestock watering programs. This well was transferred to the BLM through execution of Form wr-03, Declaration of Owner of Underground Water Rights, between the NMOSE, the BLM, and the DOE CBFO.

The P\&A work at well H-7b2 occurred between May 10-12, 2005. This well was completed in the Culebra at a shallow depth of 268 feet bgs (Figure 22). The well was scraped to the total depth and circulated. While the well was being cleaned out, circulation was lost due to split casing, detected by geophysical analysis in 2002 . To allow sufficient cementing, Baro-Seal ${ }^{\mathrm{TM}}$ was used to assist in plugging open spaces (Photo 13). Five bags of Baro-Seal ${ }^{\mathrm{TM}}$ was used in conjunction with 148.5 cubic feet of Class $C$ Neat Cement slurry, filling the well to the surface. Upon completion of the cementing, a well monument was fixed to the well location in accordance to BLM requirements (Figure 23).

\subsection{WELL WIPP-29}

WIPP-29 is located approximately 11 miles from the center of the WIPP site in Section 34, Township 22 South, and Range 29 East (Figure 24). It was drilled in 1978 as an exploratory borehole to investigate near-surface formations and the dissolution of soluble rock by groundwater. The well was located west of Nash Draw. The borehole for WIPP-29 was drilled to a depth 377 feet bgs and cased to a depth of 376 feet bgs. The casing was subsequently perforated in the Salado Formation from 216 to 250 feet bgs and the Culebra from 10 to 45 feet bgs. To separate the Culebra from the Salado Formation perforations, an inflatable packer was installed at 75 feet bgs (Figure 25) (SNL and U.S. Geological Survey 1979). The purpose of WIPP-29 was to monitor hydrostatic head in the Culebra Member. The objective under the FY 2005 program was to decommission well WIPP-29 and remove it from the monitoring network. 


\section{Basic Data Report for Well Plugging and Abandonment and Reconfiguration Activities for Fiscal Year 2005

Figure 20

Construction of Well H-4c

After Reconfiguration

(Not to Scale)

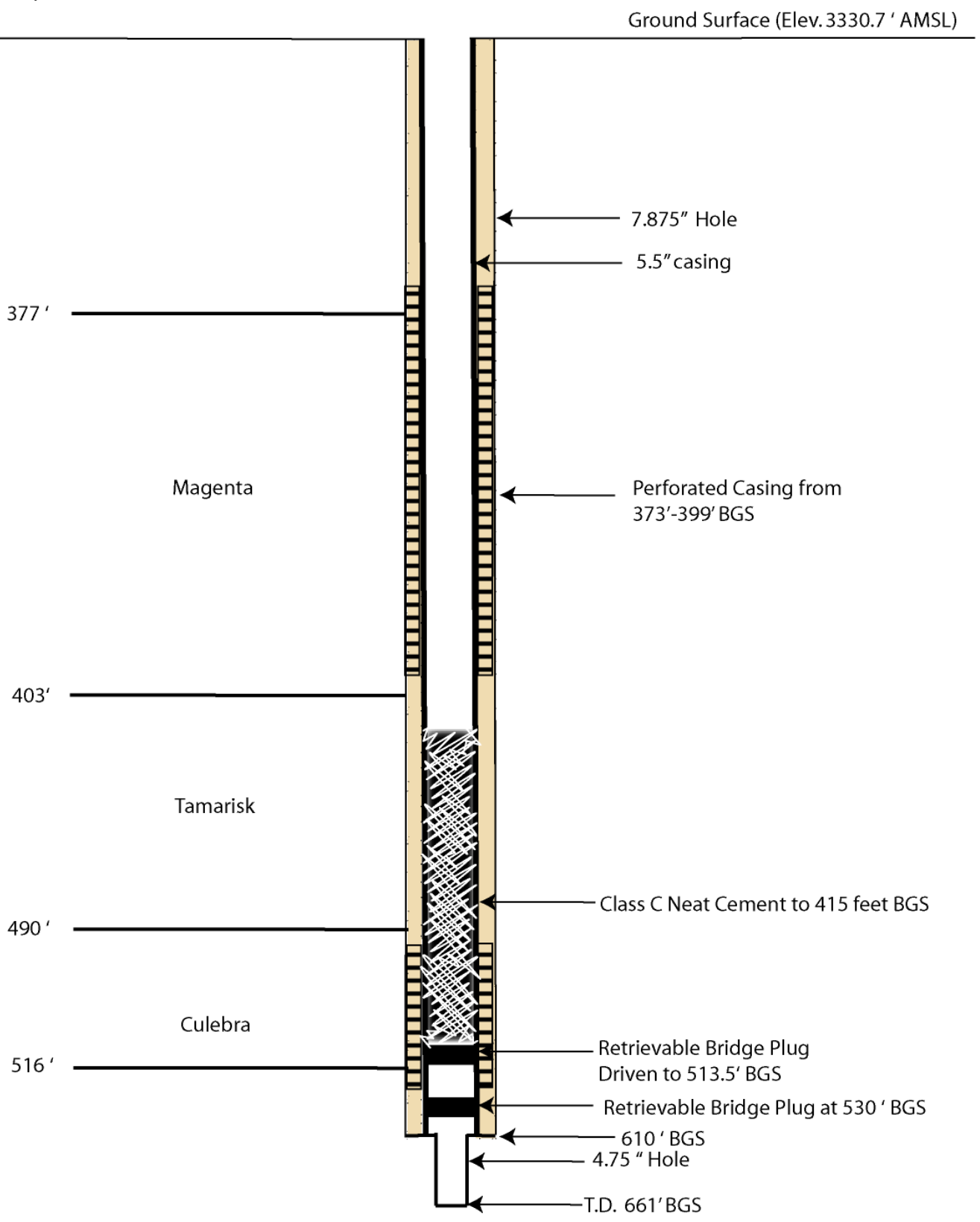




\section{Basic Data Report for Well Plugging and Abandonment and Reconfiguration Activities for Fiscal Year 2005 \\ DOE/WIPP 05-3326}

Figure 21

H-7 Well Pad Location Map

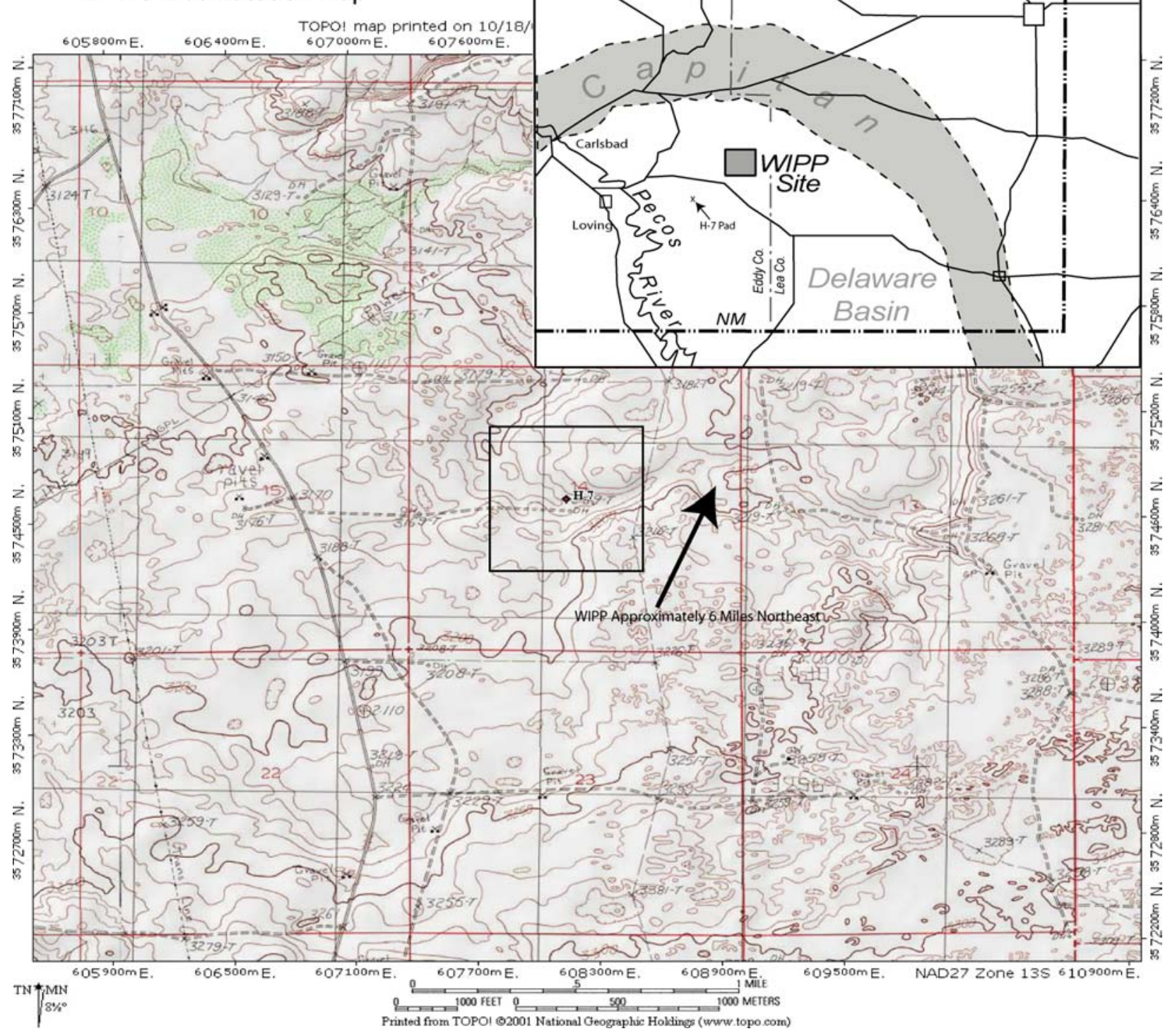




\section{Basic Data Report for Well Plugging and Abandonment and Reconfiguration Activities for Fiscal Year 2005

Figure 22

Configuration of Well H-7b2

Before P\&A

(Not to Scale)

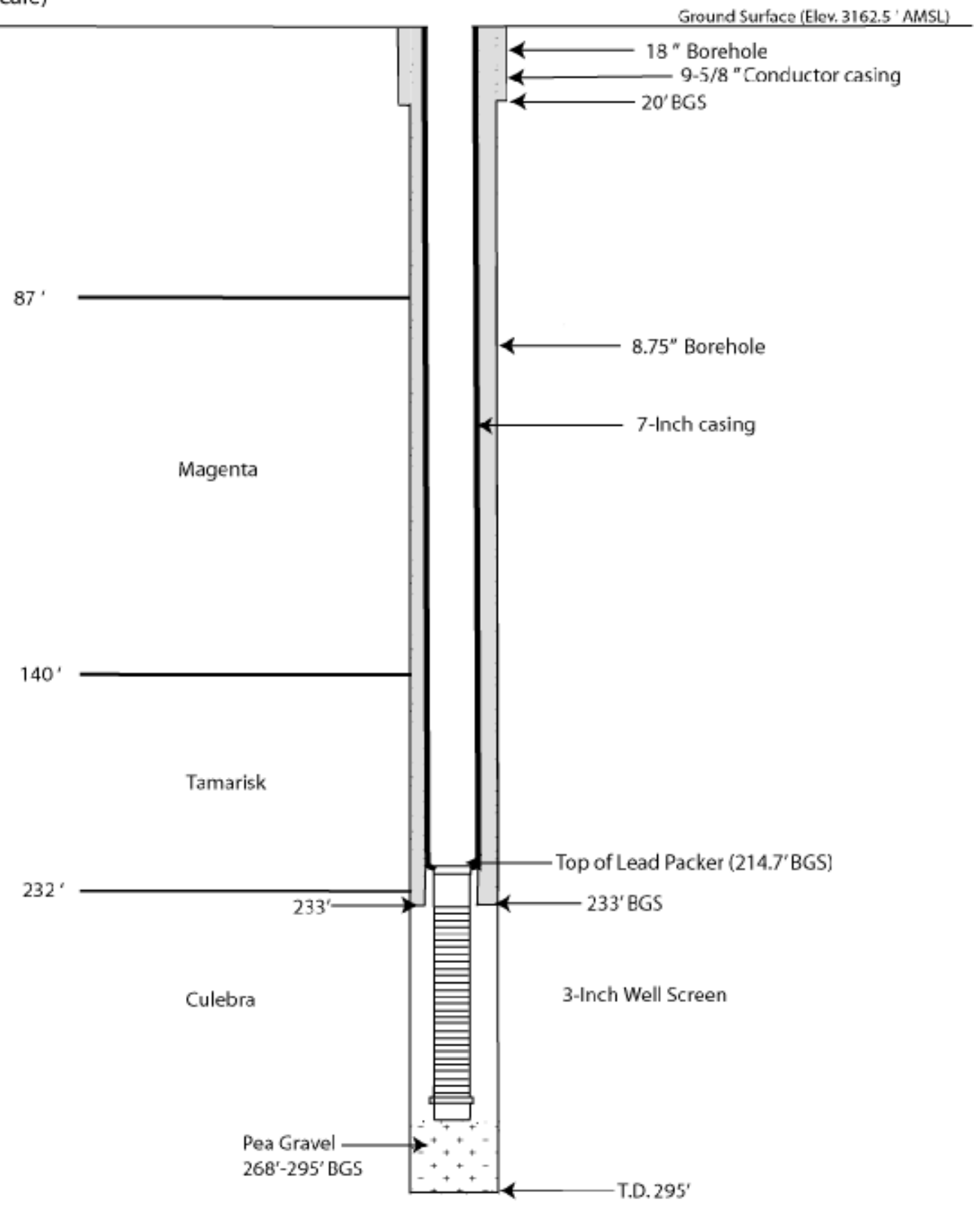




\section{Basic Data Report for Well Plugging and Abandonment and Reconfiguration Activities for Fiscal Year 2005

Figure 23

Configuration of Well $\mathrm{H}-7 \mathrm{~b} 2$

After P\&A

(Not to Scale)

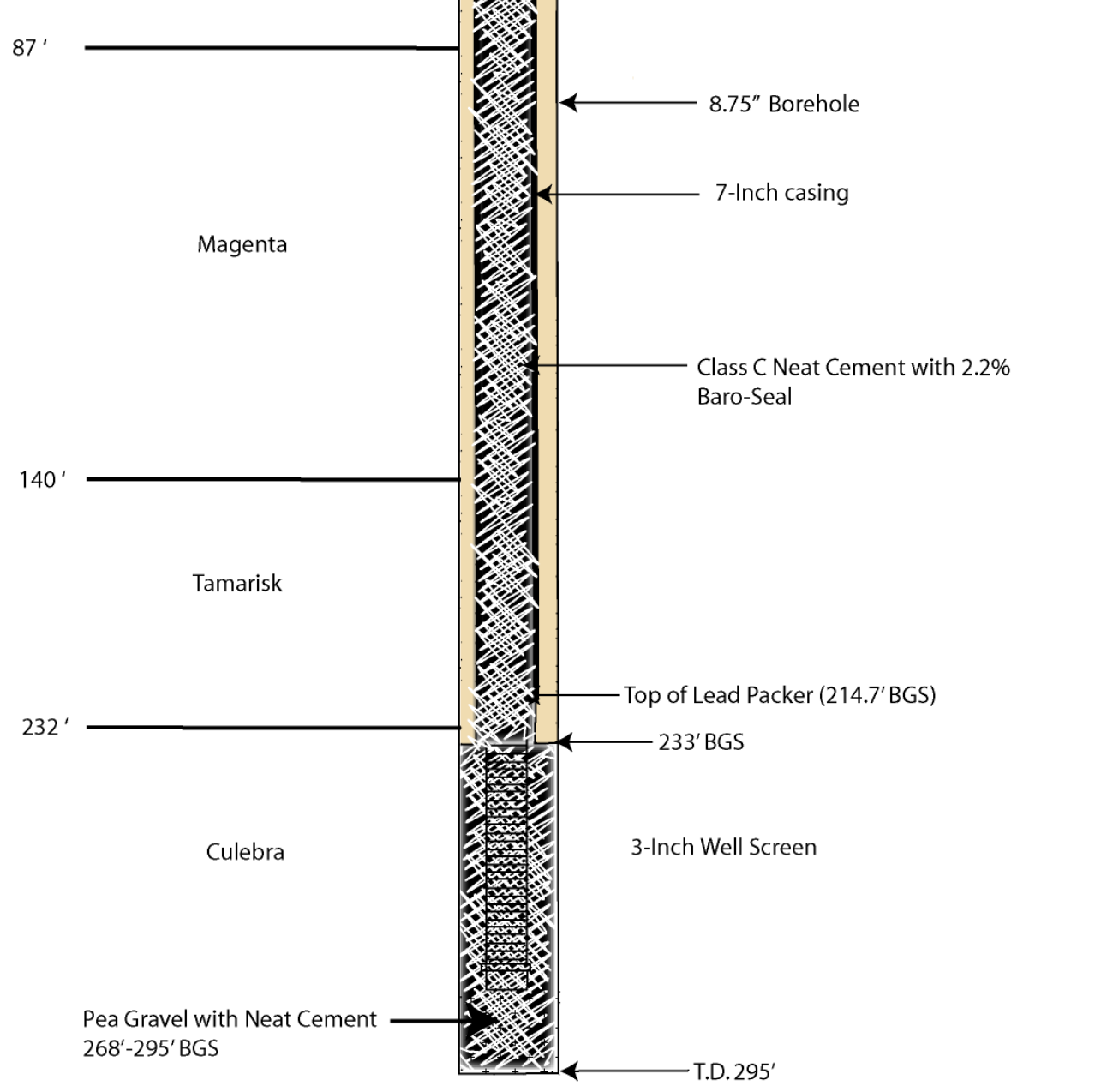




\section{Basic Data Report for Well Plugging and Abandonment and Reconfiguration Activities for Fiscal Year 2005 \\ DOE/WIPP 05-3326}

Figure 24

WIPP-29 Location Map

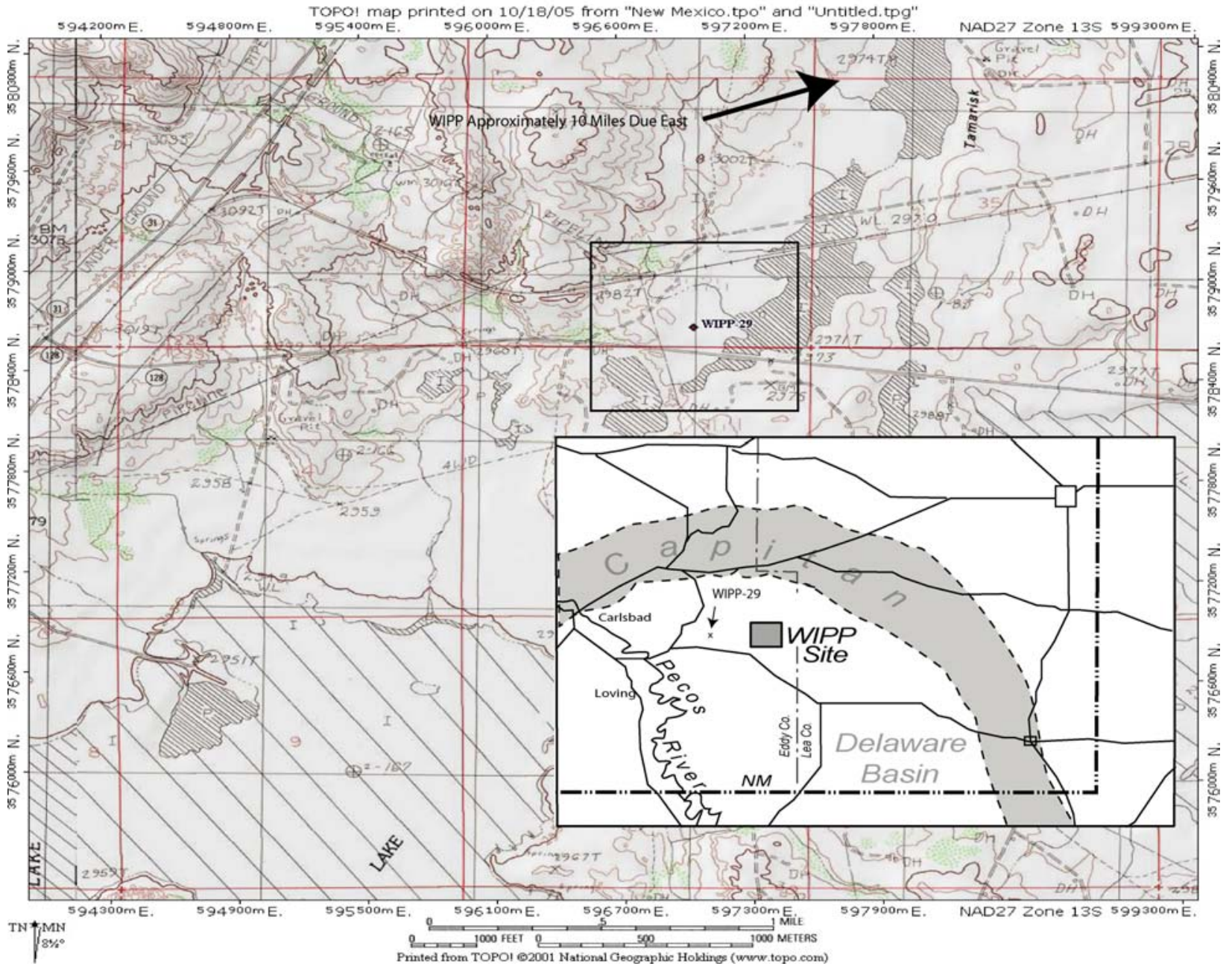




\section{Basic Data Report for Well Plugging and Abandonment and Reconfiguration Activities for Fiscal Year 2005

Figure 25

Configuration of Well WIPP-29

Before P\&A

(Not to Scale)

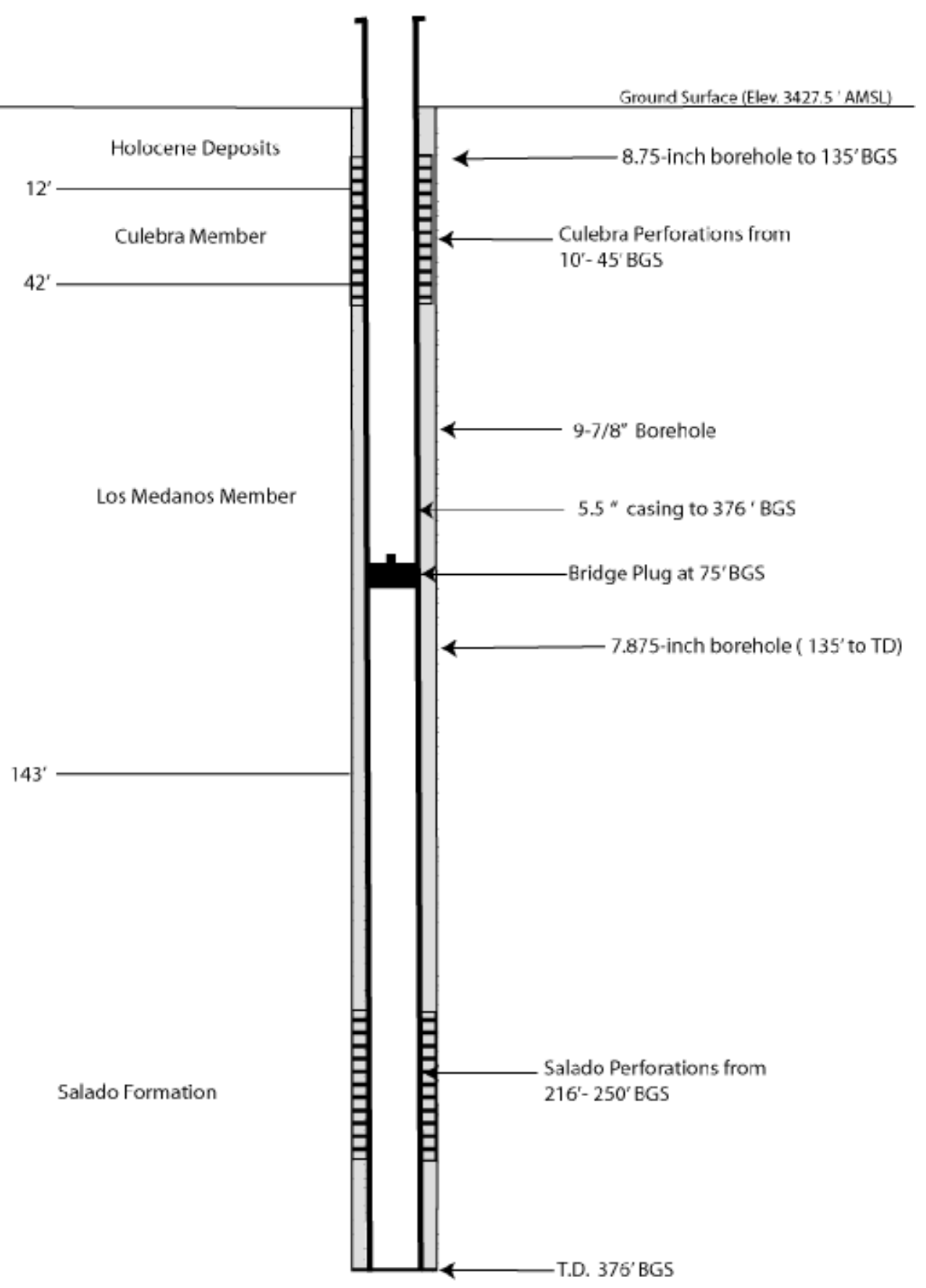




\section{Basic Data Report for Well Plugging and Abandonment and Reconfiguration Activities for Fiscal Year 2005 \\ DOE/WIPP 05-3326}

Plugging activities at WIPP-29 occurred between May 12-13, 2005. The well was entered with the tubing and a J-tool to remove the packer. The packer was removed without any problems (Photo 14). Following the packer removal the well was scraped and circulated as described in Section 2.0 of this report. Following scraping the well was cemented to the surface with 54 cubic feet of cement filling the well to the surface. Upon completion of the cementing, a well monument was fixed to the well location in accordance to BLM requirements (Figure 26) (Photo 15).

\subsection{H-6 WELL PAD}

The H-6 hydropad is located in the northwest corner of Section 18, Township 22 South, Range 31 East, near the northwest corner of the WIPP site (Figure 27). Three wells located on the $\mathrm{H}-6$ hydropad, $\mathrm{H}-6 \mathrm{a}, \mathrm{H}-6 \mathrm{~b}$, and $\mathrm{H}-6 \mathrm{c}$, were drilled and completed in June and July of 1978. Well decommissioning and reconfiguration work at this pad occurred from May 13-25, 2005.

\subsection{Well H-6a}

Well H-6a was originally completed with 5.5-inch casing cemented from ground surface to 475 feet bgs, and a 4.75-inch open hole to a total depth of 525 feet bgs. In January 1981, the well was reentered and drilled and cored to a new depth of 640 feet bgs. A PIP was thought to have been installed at a depth of 594 feet bgs on 2.375-inch tubing (Beauheim and Ruskauff 1998). Instead, the PIP was found to be set on 1.5-inch (internal diameter) galvanized pipe at 575 feet bgs (Figure 28). The purpose of well $\mathrm{H}-6 \mathrm{a}$ was to monitor hydrostatic head in the Culebra Member. The objective under the FY 2005 program was to plug and abandon well H-6a and remove it from the monitoring network.

Because the PIP was set on galvanized pipe, removing the PIP assembly (packer and pipe) was difficult due to excessive corrosion. The approach for this well was initially similar to well AEC-8 in which the tubing and packer were to be removed by attaching the tubing to the drilling rig elevators and pulling on the tubing to release the packer pressure. However, due to the metal fatigue of the pipe threads and the pipe section, the pipe was removed in pieces using an overshot tool and grapple. Additionally, several hundred feet of cable and electrical wire were bound in the hole that made removal difficult (Photos 16 and 17).

Virtually all of the galvanized pipe and 356 feet of transducer wire and cable were removed from the well but attempts to remove the packer were unsuccessful. The decision was then made, and agreed to by the NMOSE, to drive the packer as far as possible into the well. 


\section{Basic Data Report for Well Plugging and Abandonment and Reconfiguration Activities for Fiscal Year 2005 DOE/WIPP 05-3326}

Figure 26

Configuration of Well WIPP-29

After P\&A

(Not to Scale)

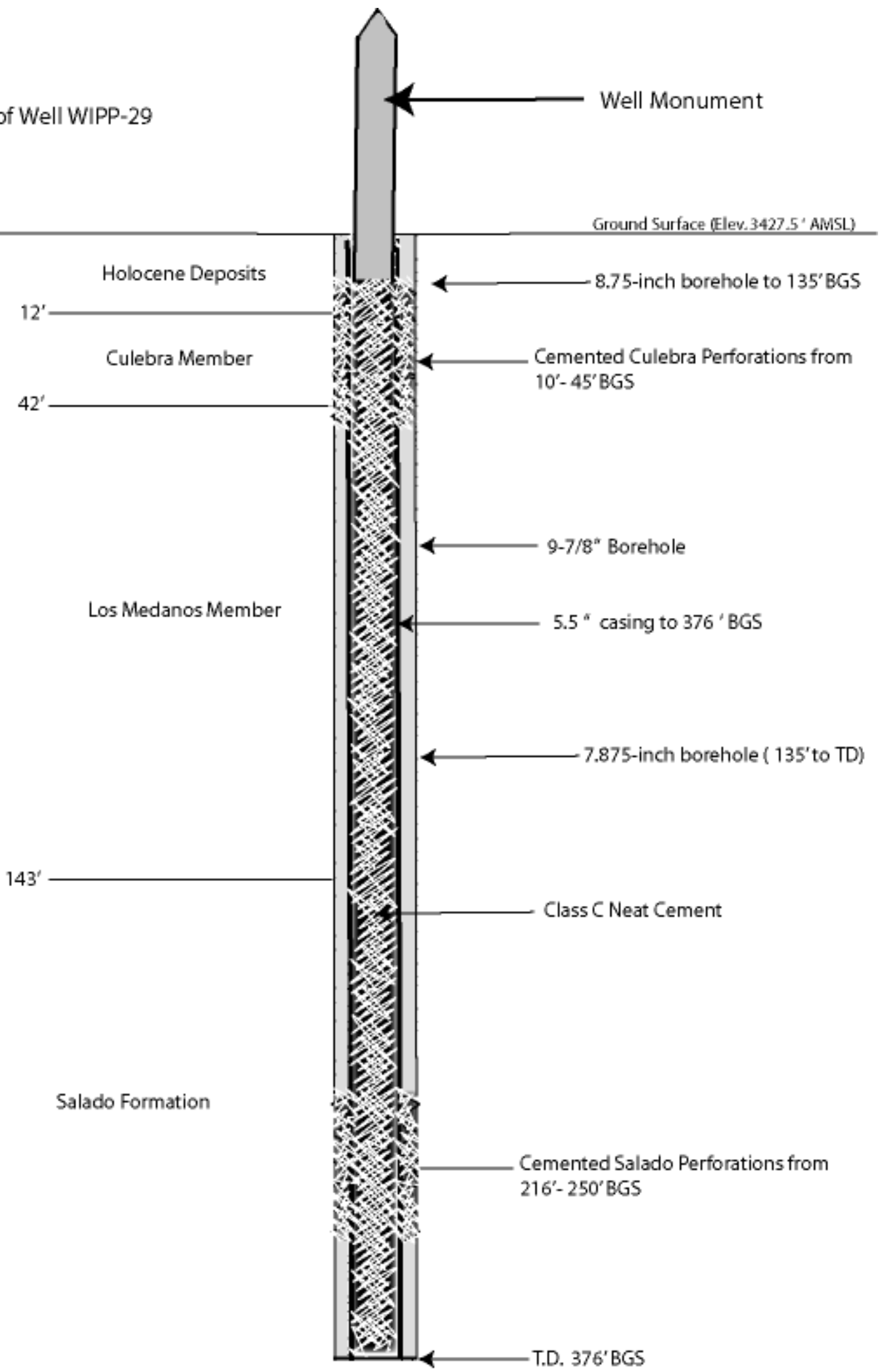




\section{Basic Data Report for Well Plugging and Abandonment and Reconfiguration Activities for Fiscal Year 2005

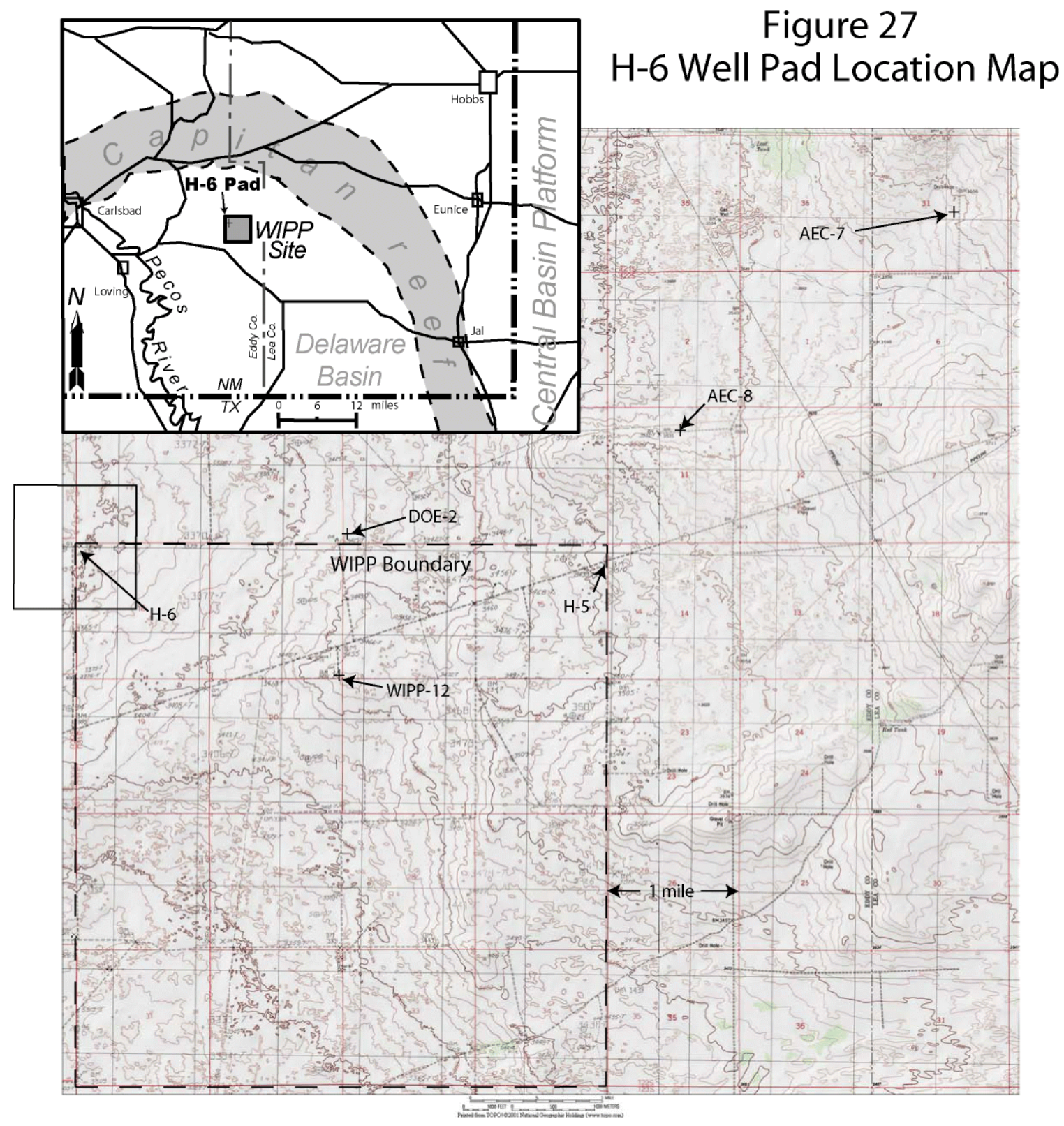


Figure 28

Construction of Well H-6a

Before P\&A

(Not to Scale)

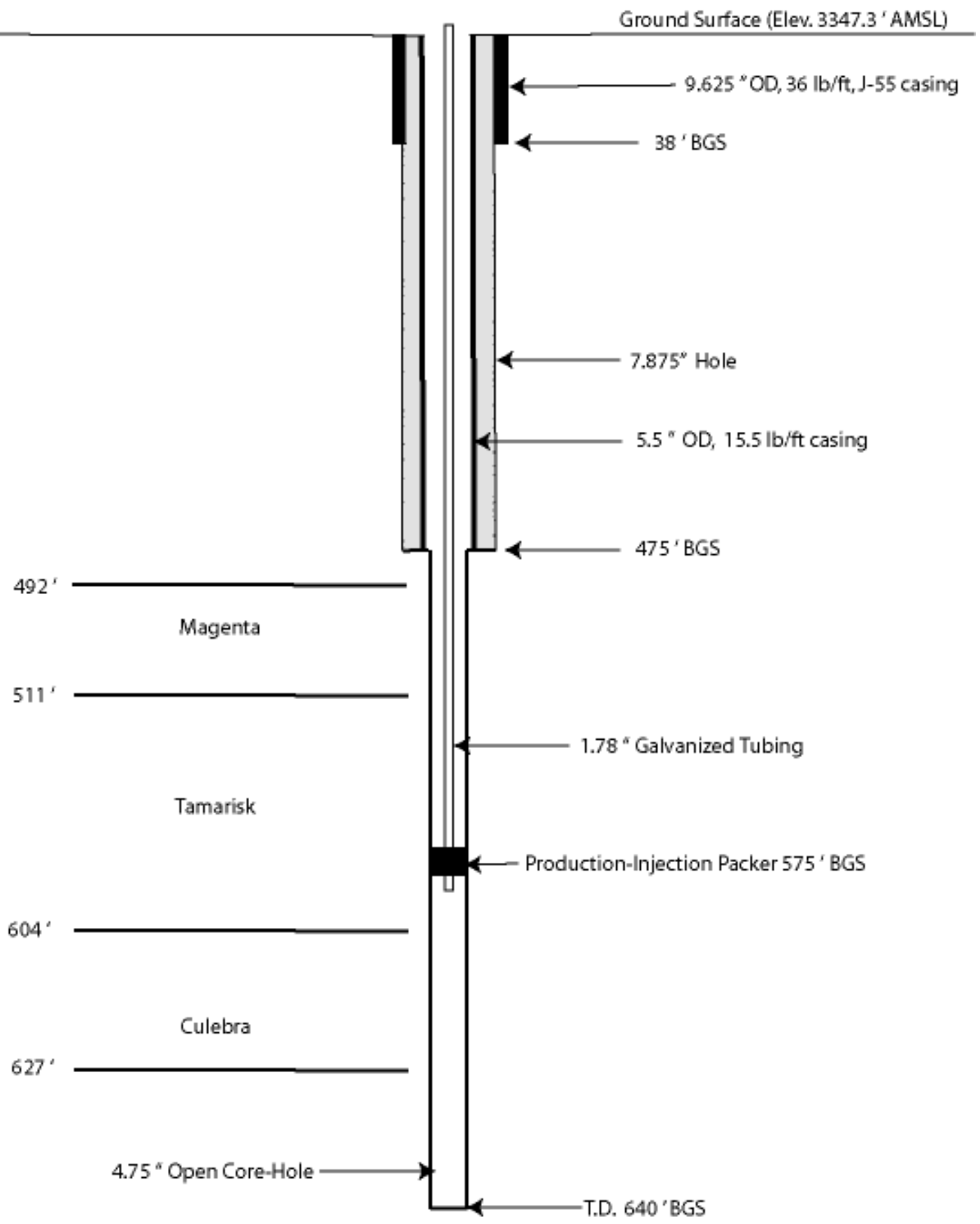




\section{Basic Data Report for Well Plugging and Abandonment and Reconfiguration Activities for Fiscal Year 2005 \\ DOE/WIPP 05-3326}

Several drill collars were loaded onto the packer inside the well. The maximum depth that could be achieved was 575 feet bgs, representing no incremental progress. It appeared that rock fall from the open hole below the packer prevented the unit from being driven deeper. After attempting to drive the packer, the well was circulated in preparation for cementing. The well was filled with 83 cubic feet of Class $C$ Neat cement slurry, filling the well to the surface. Upon completion, of the cementing a well monument was fixed to the well location in accordance to BLM requirements (Figure 29).

\subsection{Well H-6c}

Well H-6c was completed with 5.5-inch casing cemented to a depth of 699 feet bgs and a 4.75-inch open hole to a total depth of 741 feet bgs. In January 1981, the casing in well $\mathrm{H}-6 \mathrm{c}$ was perforated from 604 to 631 feet bgs to provide communication with the Culebra Member, and a bridge plug was set at 641 feet bgs to separate the Culebra from the underlying open portion of the hole (Beauheim and Ruskauff 1998). In 1986, the casing in well H-6c was perforated from 490 to 514 feet bgs and a bridge plug reportedly set at 527 feet bgs to provide communication to the Magenta (Figure 30).

Well H-6c was a dual-completion well used to monitor hydrostatic head in the Magenta Member of the Rustler Formation. The objective under this program was to reconfigure well $\mathrm{H}-6 \mathrm{c}$ as a Magenta-only monitor well, sealing off the Culebra portion. This well had two inflatable packers being used as bridge plugs to separate the Culebra and Magenta Members from each other, and the Culebra from the open hole below, respectively. Work began by scraping the upper part of the casing to the top of the upper packer, followed by circulation of the well to remove debris. The upper packer was encountered at a depth of 524 feet bgs, shallower than documented.

A J-tool was used to remove the upper packer almost without incident. The packer was removed from the well, however, one-half of the rubber element stripped from the packer and remained in the well at a depth of 160 feet. In order to get the rubber element out of the hole, the drilling contractor fabricated a barbed spear to extract the remaining element from the well (Photo 18). After the element was removed from the well, the remaining casing was scraped and circulated down to the lower packer at 641 feet bgs.

Retrieving the lower packer proved difficult. A J-tool was used to attempt retrieval, but the packer would not move after several hours. A decision was made, and approved by the NMOSE, to leave the packer in the hole at a depth of 641 feet bgs. Following activities to remove the packers, the well was cemented up to a depth of 534 feet bgs, allowing exposure to the Magenta for monitoring (Figure 31). 


\section{Basic Data Report for Well Plugging and Abandonment and Reconfiguration Activities for Fiscal Year 2005

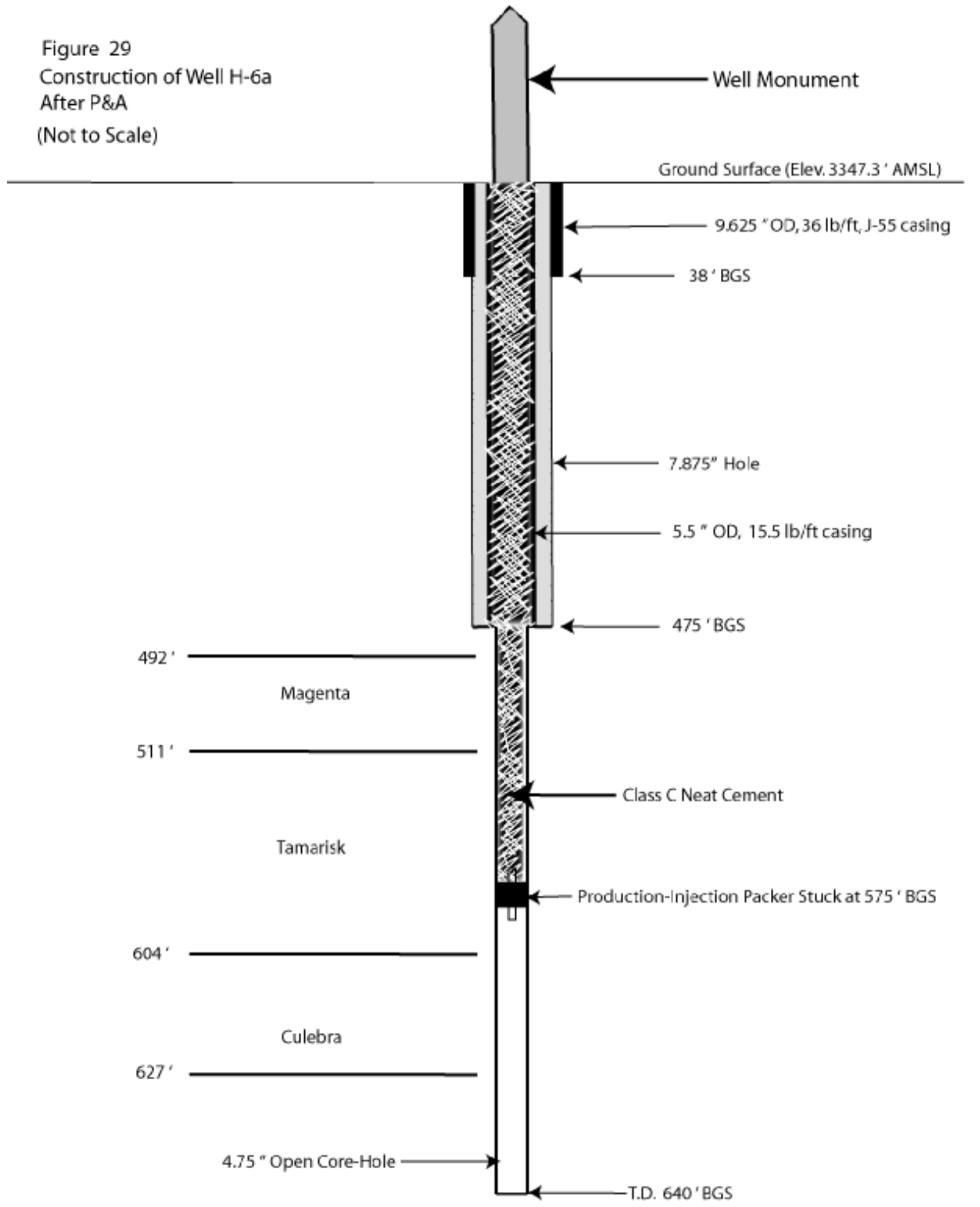




\section{Basic Data Report for Well Plugging and Abandonment and Reconfiguration Activities for Fiscal Year 2005 \\ DOE/WIPP 05-3326}

Figure 30

Construction of Well H-6c

Before Reconfiguration

(Not to Scale)

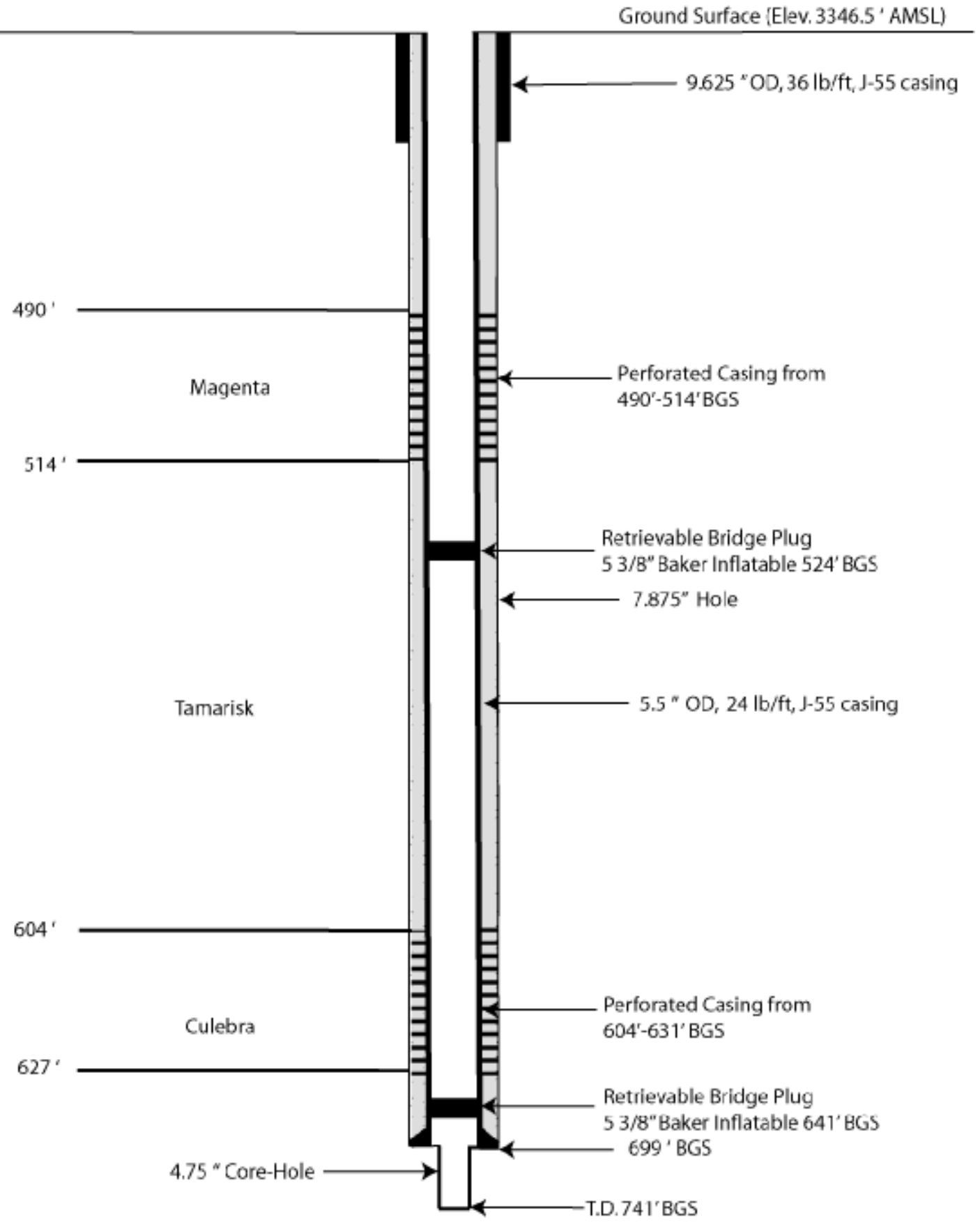




\section{Basic Data Report for Well Plugging and Abandonment and Reconfiguration Activities for Fiscal Year 2005

Figure 31

Construction of Well H-6c

After Reconfiguration

(Not to Scale)

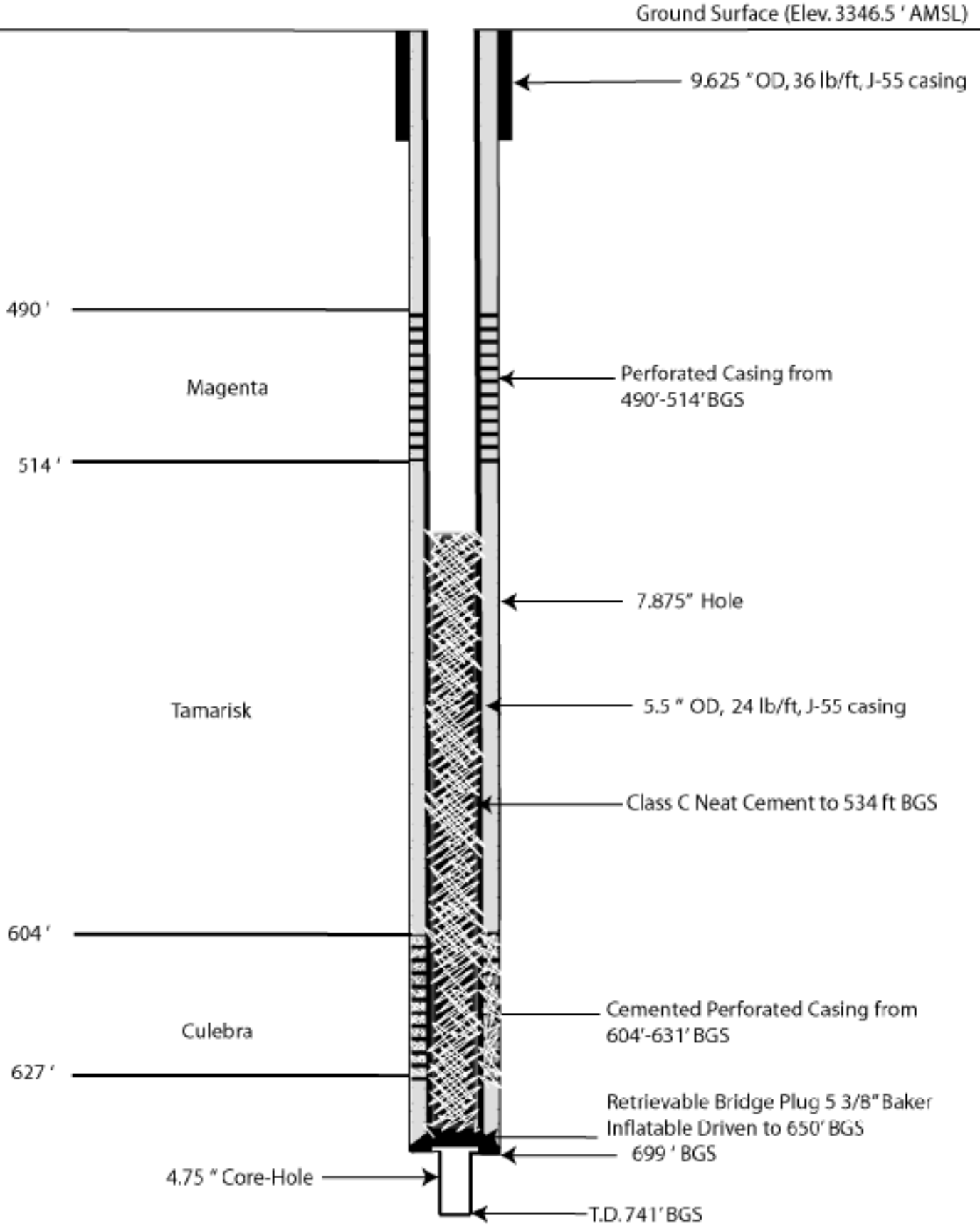




\section{Basic Data Report for Well Plugging and Abandonment and Reconfiguration Activities for Fiscal Year 2005 \\ DOE/WIPP 05-3326}

\section{$13.0 \quad \mathrm{H}-11$ WELL PAD}

The $\mathrm{H}-11$ hydropad is located in Section 33, Township 22 South, Range 31 East, approximately 2.5 miles southeast of the center of the WIPP site (Figure 32). The $\mathrm{H}-11$ hydropad originally consisted of four wells completed to the Culebra Member of the Rustler Formation. These wells are identified as $\mathrm{H}-11 \mathrm{~b} 1, \mathrm{H}-11 \mathrm{~b} 2, \mathrm{H}-11 \mathrm{~b} 3$, and $\mathrm{H}-11 \mathrm{~b} 4$. Wells $\mathrm{H}-11 \mathrm{~b} 1, \mathrm{H}-11 \mathrm{~b} 2$, and $\mathrm{H}-11 \mathrm{~b} 3$ were drilled and completed between August 1983 and January 1984. Well H-11b4 was drilled and completed in 1988 (Mercer 1990). Wells $\mathrm{H}-11 \mathrm{~b} 1, \mathrm{H}-11 \mathrm{~b} 2$, and $\mathrm{H}-11 \mathrm{~b} 3$ were drilled by first coring through the Culebra into the Los Medaños Member of the Rustler Formation, near the top of the halite in that unit. The boreholes were then reamed to the top of the Culebra and casing was installed and cemented to provide open-hole access to the Culebra. Well H-11b3 was plugged and abandoned in 2002, leaving three Culebra wells on this pad $(\mathrm{H}-11 \mathrm{~b} 1$, $\mathrm{H}-11 \mathrm{~b} 2$, and $\mathrm{H}-11 \mathrm{~b} 4)$. The $\mathrm{FY} 2005$ program plugging and reconfiguration activities at the $\mathrm{H}-11$ well pad occurred May 25-28, 2005.

\subsection{Well H-11b2}

Well $\mathrm{H}-11 \mathrm{~b} 2$ was the first well workover at this pad during the FY 2005 program. Well $\mathrm{H}-11 \mathrm{~b} 2$ was completed with 5.5-inch casing cemented to a depth of 733.39 feet bgs and a 4.75-inch open hole to a total depth of 776 feet bgs (Mercer 1990). In March 2001, the well was fitted with an inflatable bridge plug (PIP) at a depth of 663.1 feet bgs, just below the Magenta Member. Following the installation of the bridge plug, the well was perforated at the Magenta interval from 622 to 650 feet bgs (Figure 33).

The purpose of well $\mathrm{H}-11 \mathrm{~b} 2$ was to monitor the hydrostatic head in the Magenta Member of the Rustler Formation. The objective under the FY 2005 program was to plug well $\mathrm{H}-11 \mathrm{~b} 2$ back to 670 feet bgs, below the Magenta perforations, so that a bridge plug is no longer needed to isolate the Magenta from the Culebra.

The packer was removed using a J-tool without any problems (Photo 19). Following activities to remove the packer, the well was scraped, circulated, and cemented up to a depth of 670 feet bgs using 14.5 cubic feet of Class C Neat cement slurry, allowing exposure to the Magenta for monitoring (Figure 34).

\subsection{Well $\mathrm{H}-11 \mathrm{~b} 1$}

Well $\mathrm{H}-11 \mathrm{~b} 1$ was completed with 5.5 -inch casing cemented from ground surface to 732 feet bgs, and a 4.75-inch open hole to a total depth of 785 feet bgs (Mercer 1990). The purpose of well $\mathrm{H}-11 \mathrm{~b} 1$ was to monitor the hydrostatic head in the Culebra Member of the Rustler Formation (Figure 35). The objective under the FY 2005 program was to plug and abandon well $\mathrm{H}-11 \mathrm{~b} 1$ and remove it from the monitoring network.

This well was not configured with any packer assembly, so the plugging effort was straight forward. The well was scraped and circulated to a depth of 776 feet bgs, nine feet from the original depth. It was apparent that the bottom of the hole had some rock 


\section{Basic Data Report for Well Plugging and Abandonment and Reconfiguration Activities for Fiscal Year 2005

fall at the base, preventing circulation to the original depth. Following preparation for cementing, the well was filled with 108 cubic feet of Class C Neat Cement slurry, filling the well to the surface. Upon completion of the cementing, a well monument was fixed to the well location in accordance to BLM requirements (Figure 36). 
Basic Data Report for Well Plugging and Abandonment and Reconfiguration Activities for Fiscal Year 2005

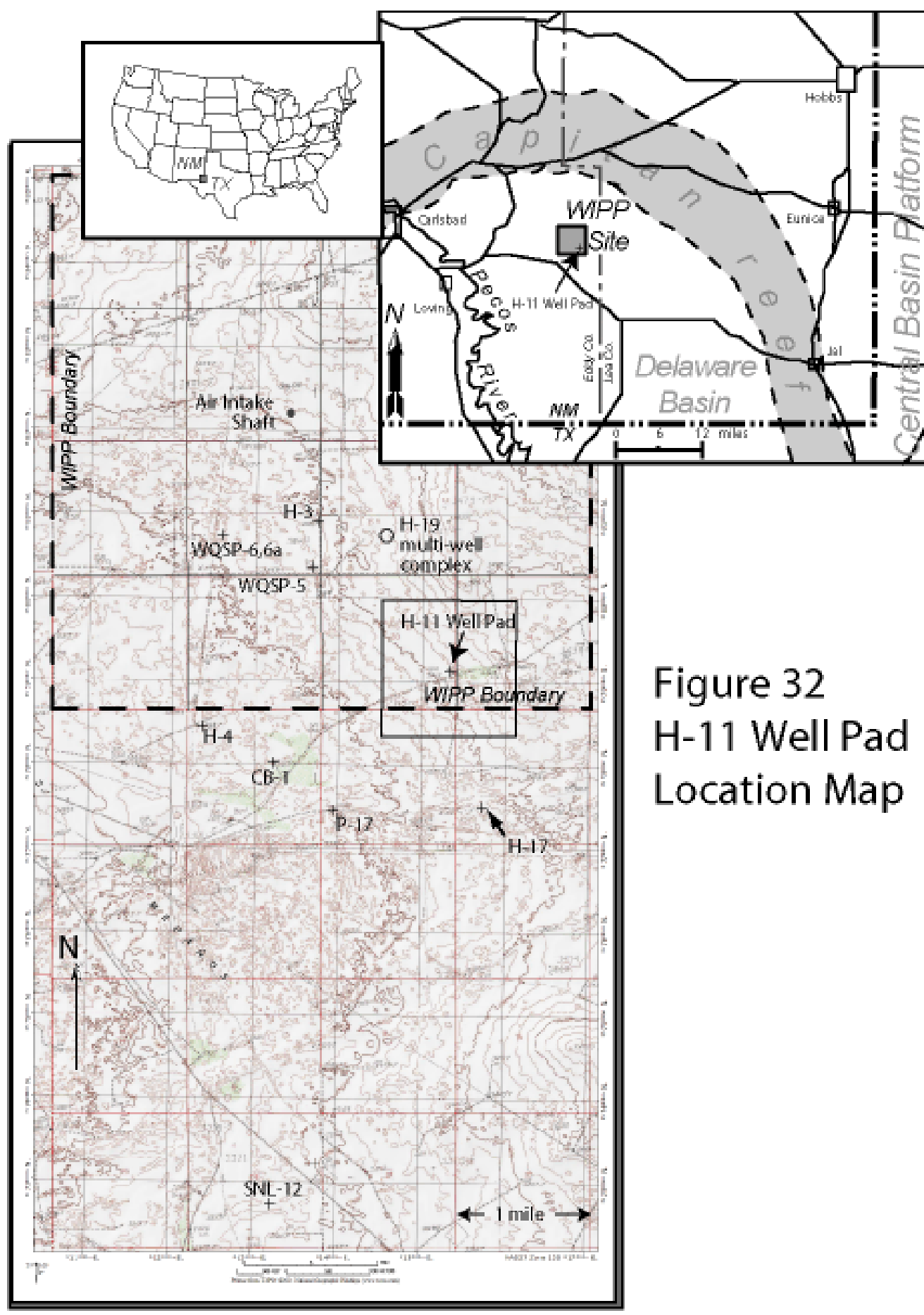




\section{Basic Data Report for Well Plugging and Abandonment and Reconfiguration Activities for Fiscal Year 2005

Figure 33

Construction of Well H-11b2

Before Reconfiguration

(Not to Scale)

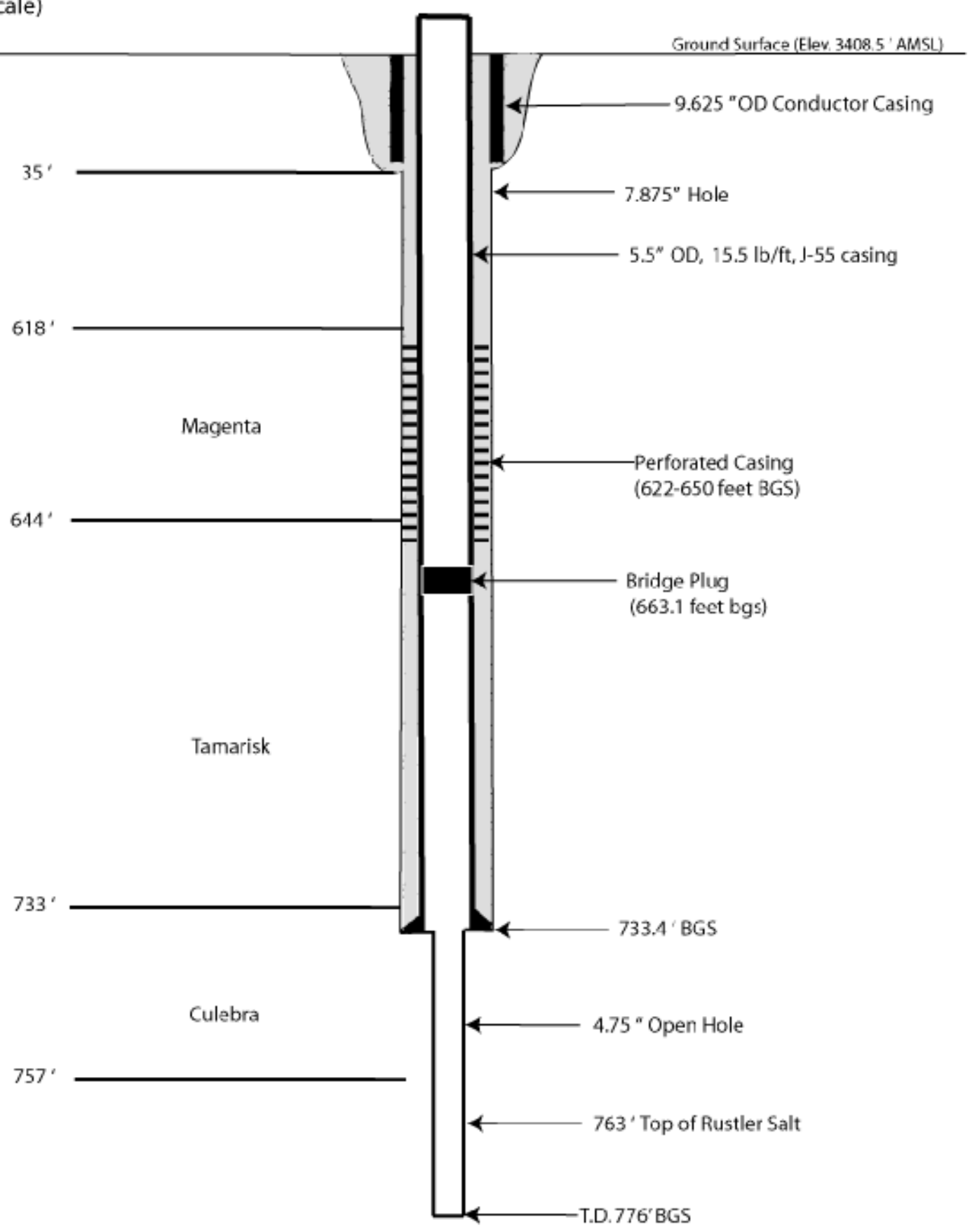




\section{Basic Data Report for Well Plugging and Abandonment and Reconfiguration Activities for Fiscal Year 2005

Figure 34

Construction of Well H-11b2

After Reconfiguration

(Not to Scale)

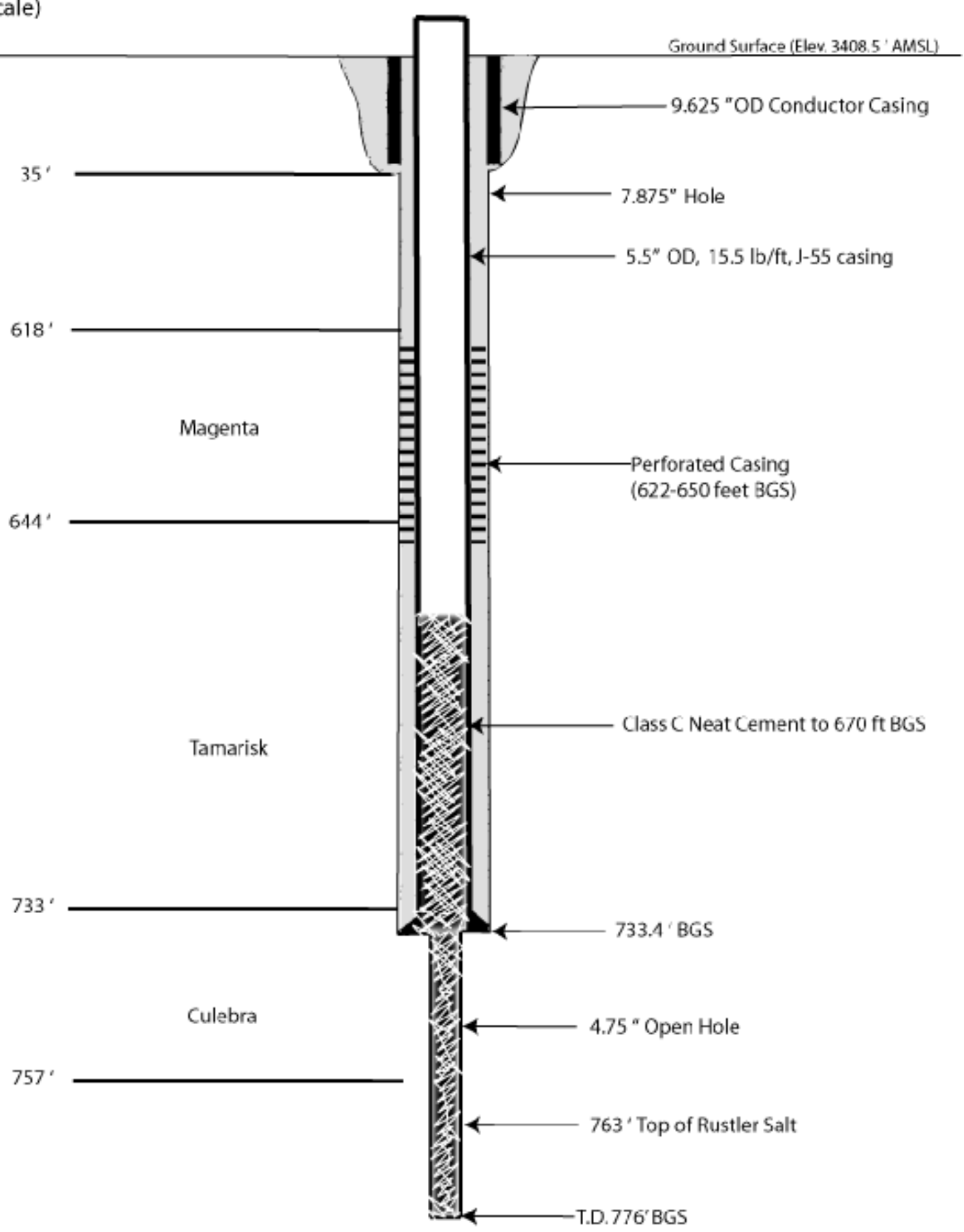


Basic Data Report for Well Plugging and Abandonment and

Reconfiguration Activities for Fiscal Year 2005

DOE/WIPP 05-3326

Figure 35

Construction of Well $\mathrm{H}-11 \mathrm{~b} 1$

Before P\&A

(Not to Scale)

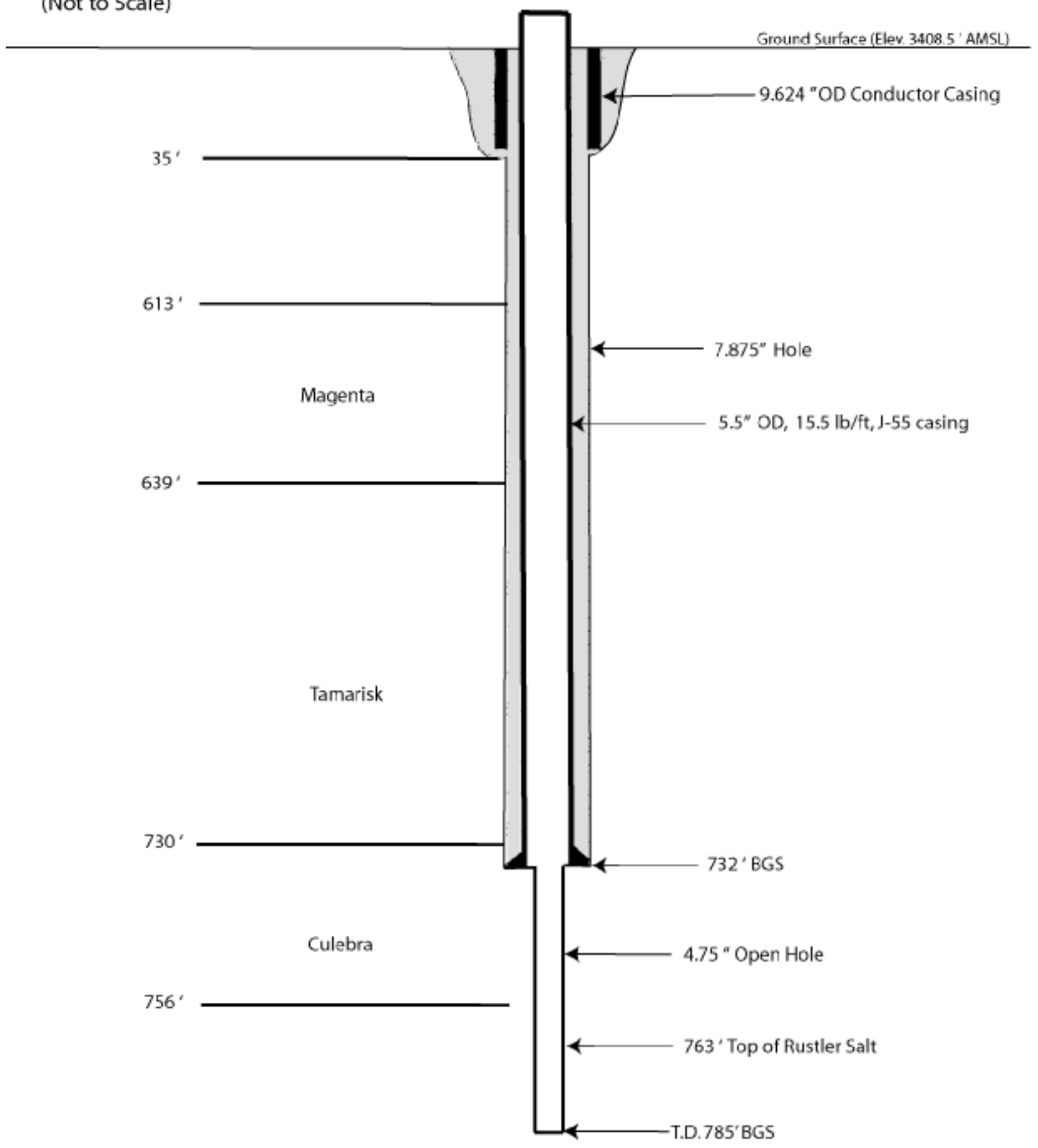




\section{Basic Data Report for Well Plugging and Abandonment and Reconfiguration Activities for Fiscal Year 2005 DOE/WIPP 05-3326}

Figure 36

Construction of Well $\mathrm{H}-11 \mathrm{~b} 1$ After P\&A

(Not to Scale)

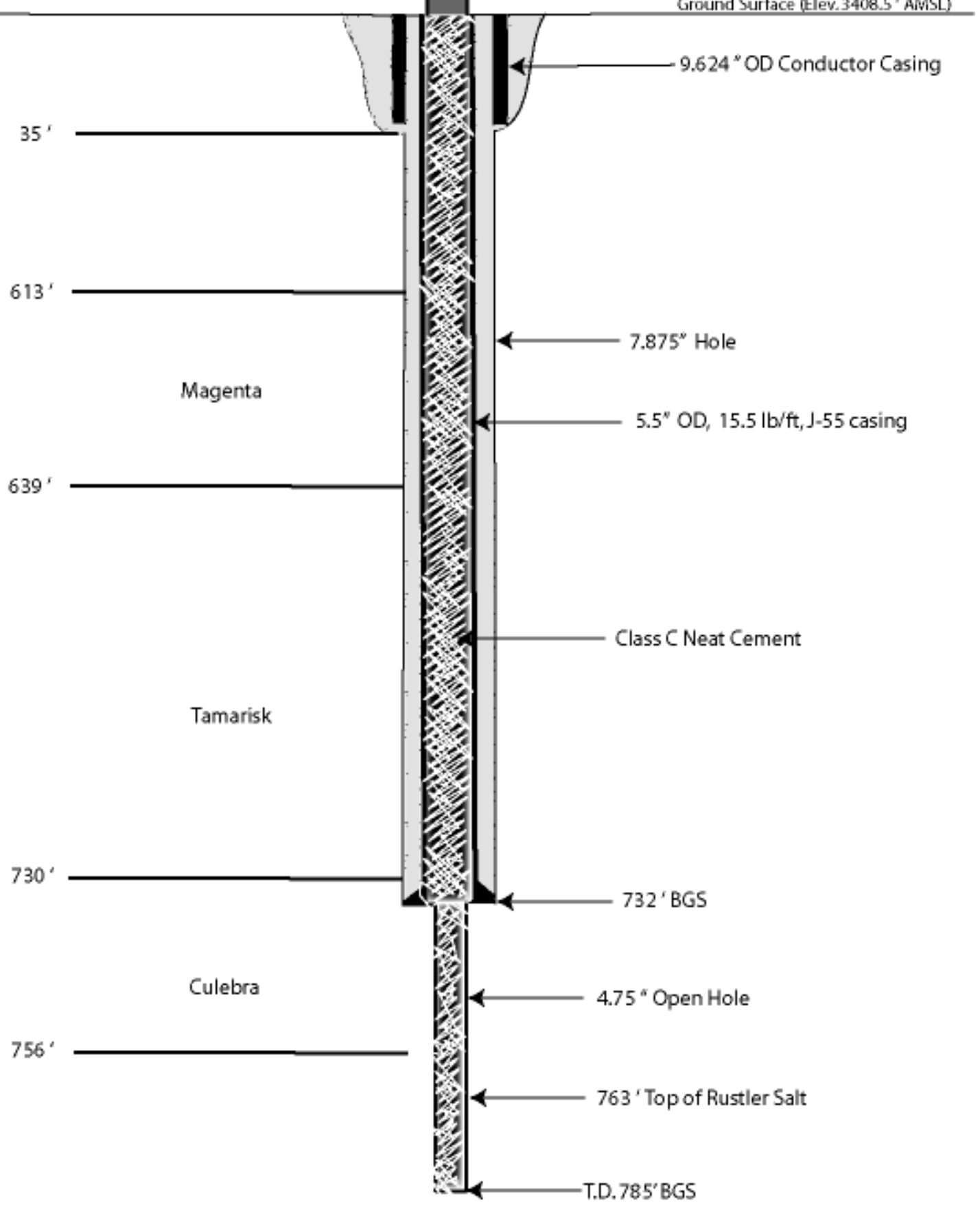




\section{Basic Data Report for Well Plugging and Abandonment and Reconfiguration Activities for Fiscal Year 2005 \\ DOE/WIPP 05-3326}

\subsection{WELL WIPP-21}

Well WIPP-21 was located in eastern Eddy County, New Mexico, in the southeast quarter of Section 20, Township 22 South, Range 31 East (Figure 37). The location was originally a testing borehole only. It was originally drilled in 1978 to a total depth of 1,046 feet bgs, and then loaded with brine mud pending further testing, plugging, or recompletion. In 1985, the borehole was reentered to complete it as a Culebra monitoring well. Recompletion consisted of cleaning and reaming the hole to a diameter of 7.875 inches to a depth of 868 feet bgs, and cleaning the hole and cementing from 868 feet bgs to total depth (1,046 feet bgs). The well was completed with 5.5-inch casing to a depth of 868 feet bgs and then perforating the Culebra interval from 727 to 751 feet bgs (Figure 38) (Saulnier et al., 1987).

The purpose of well WIPP-21 was to monitor hydrostatic head in the Culebra Member. The objective under the FY 2005 program was to plug and abandon the well and remove it from the monitoring network. Activities at this well occurred on May 28-29, 2005. This well was not configured with any packer assembly, so the plugging effort was very straight forward. The well was scraped and circulated to a depth of 946 feet bgs, indicating the bottom of the well was not completely filled with cement as documented. Following preparation for cementing, the well was filled with 135 cubic feet of Class C Neat Cement slurry, filling the well to the surface. Upon completion of the cementing, a well monument was fixed to the well location in accordance to BLM requirements (Figure 39 ).

\subsection{WELL WIPP-22}

Well WIPP-22 was located in eastern Eddy County, New Mexico, in the southeast quarter of Section 20, Township 22 South, and Range 31 East (Figure 40). The location was originally a testing borehole only. It was originally drilled in 1978 to a total depth of 1,452 feet bgs, and then loaded with brine mud pending further testing, plugging, or recompletion. In 1985, the borehole was reentered to complete it as a Culebra monitoring well. Reconfiguration consisted of cleaning and reaming the hole to a diameter of 7.875-inches to a depth of 950 feet bgs, and cleaning the hole and cementing from 950 feet bgs to total depth (1452 feet bgs). The well was completed by cementing 5.5-inch casing to a depth of 950 feet bgs and then perforating at the Culebra interval from 748 to 770 feet bgs (Figure 41) (Saulnier et al., 1987).

The purpose of well WIPP-22 was to monitor hydrostatic head in the Culebra Member. The objective under the FY 2005 program was to plug and abandon the well and remove it from the monitoring network. Activities at this well occurred on May 29-30, 2005. This well was not configured with any packer assembly, so the plugging effort was very straightforward. The well was scraped and circulated to total depth, 941 feet bgs. Following preparation for cementing, the well was filled with 135 cubic feet of Class $\mathrm{C}$ Neat Cement slurry, filling the well to the surface. Upon completion of the cementing, a well monument was fixed to the well location in accordance to BLM requirements (Figure 42). 
Basic Data Report for Well Plugging and Abandonment and Reconfiguration Activities for Fiscal Year 2005

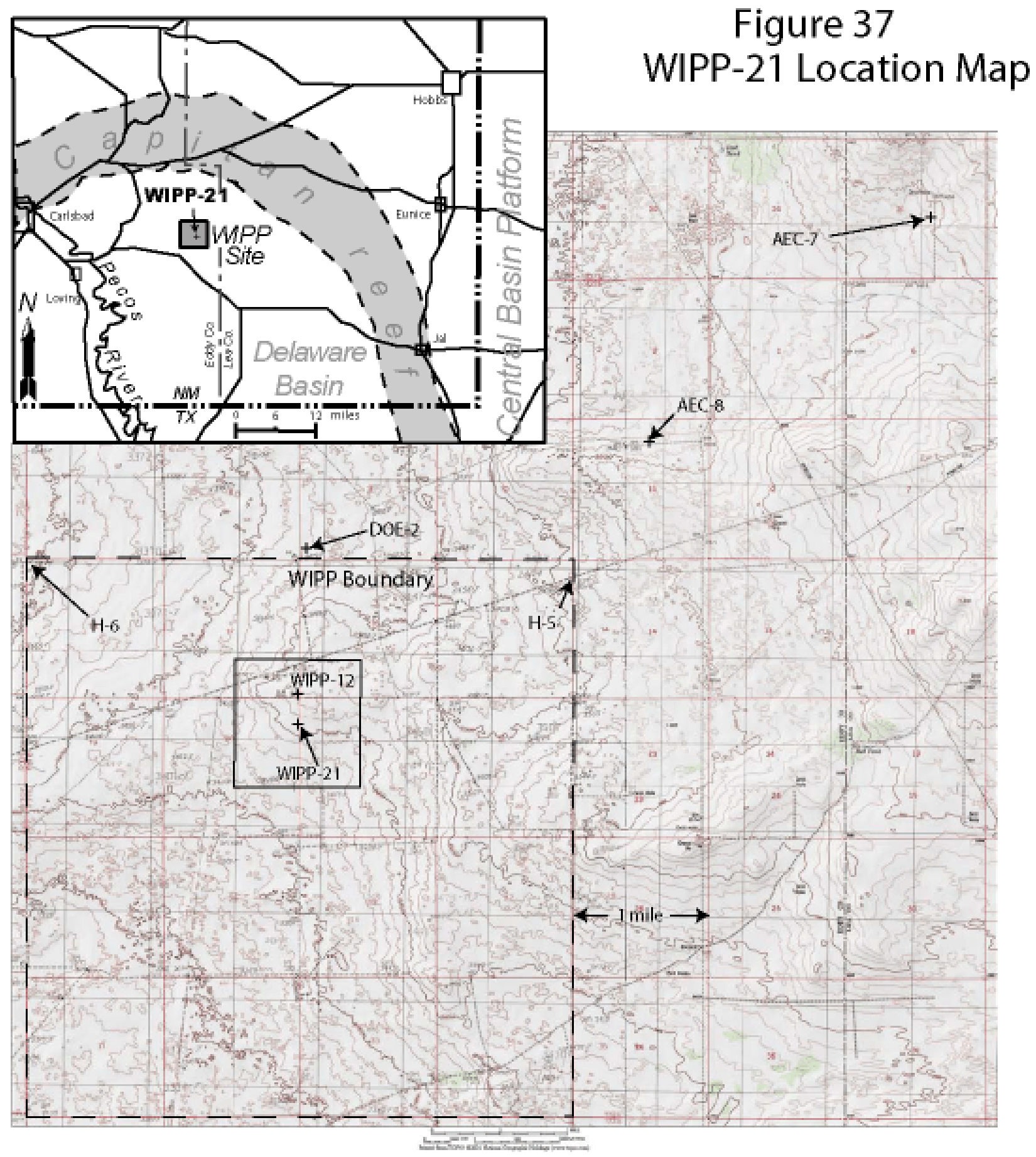




\section{Basic Data Report for Well Plugging and Abandonment and Reconfiguration Activities for Fiscal Year 2005

Figure 38

Configuration of Well WIPP-21

Before P\&A

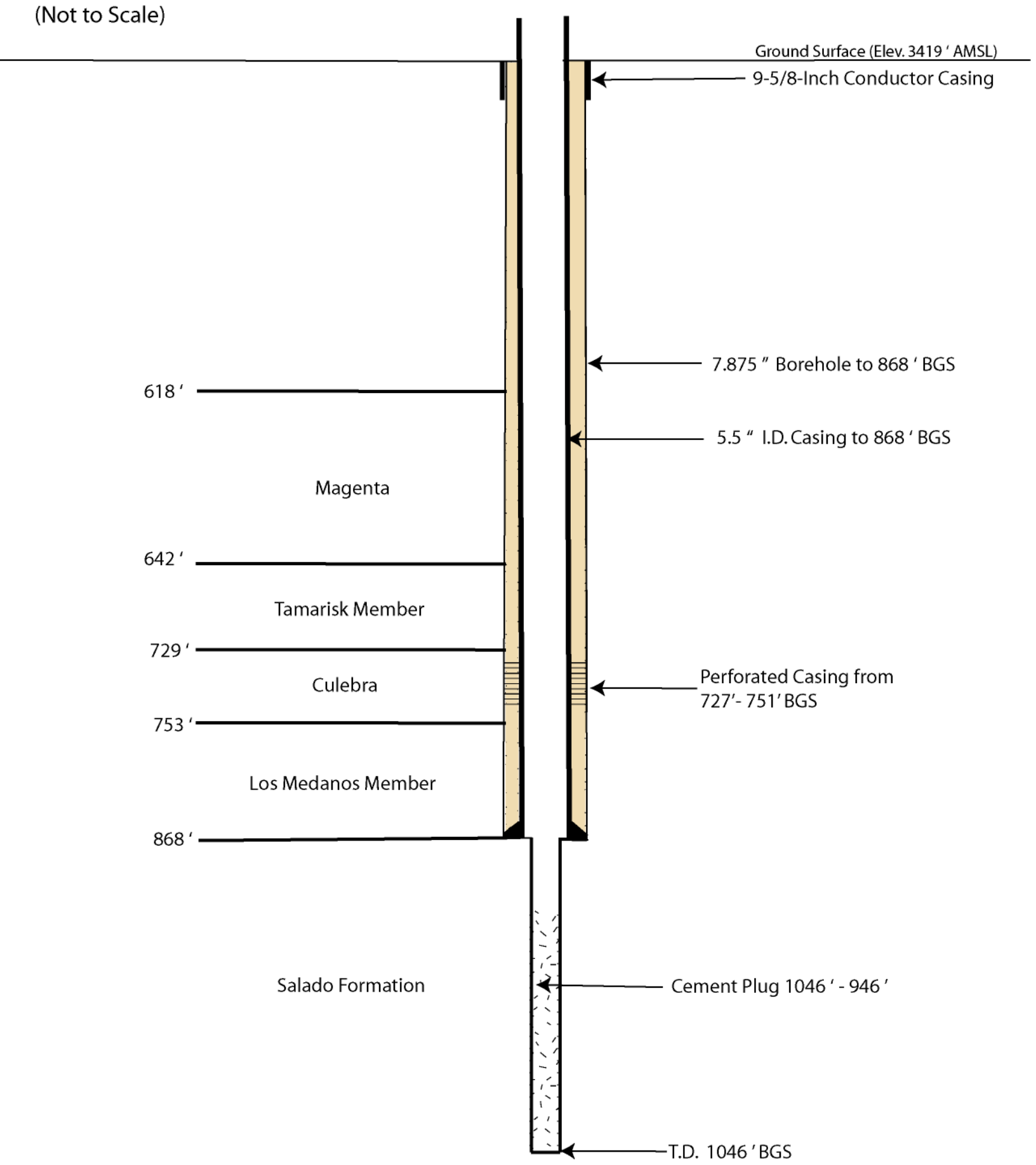




\section{Basic Data Report for Well Plugging and Abandonment and Reconfiguration Activities for Fiscal Year 2005

Figure 39

Configuration of Well WIPP-21

After P\&A

(Not to Scale)
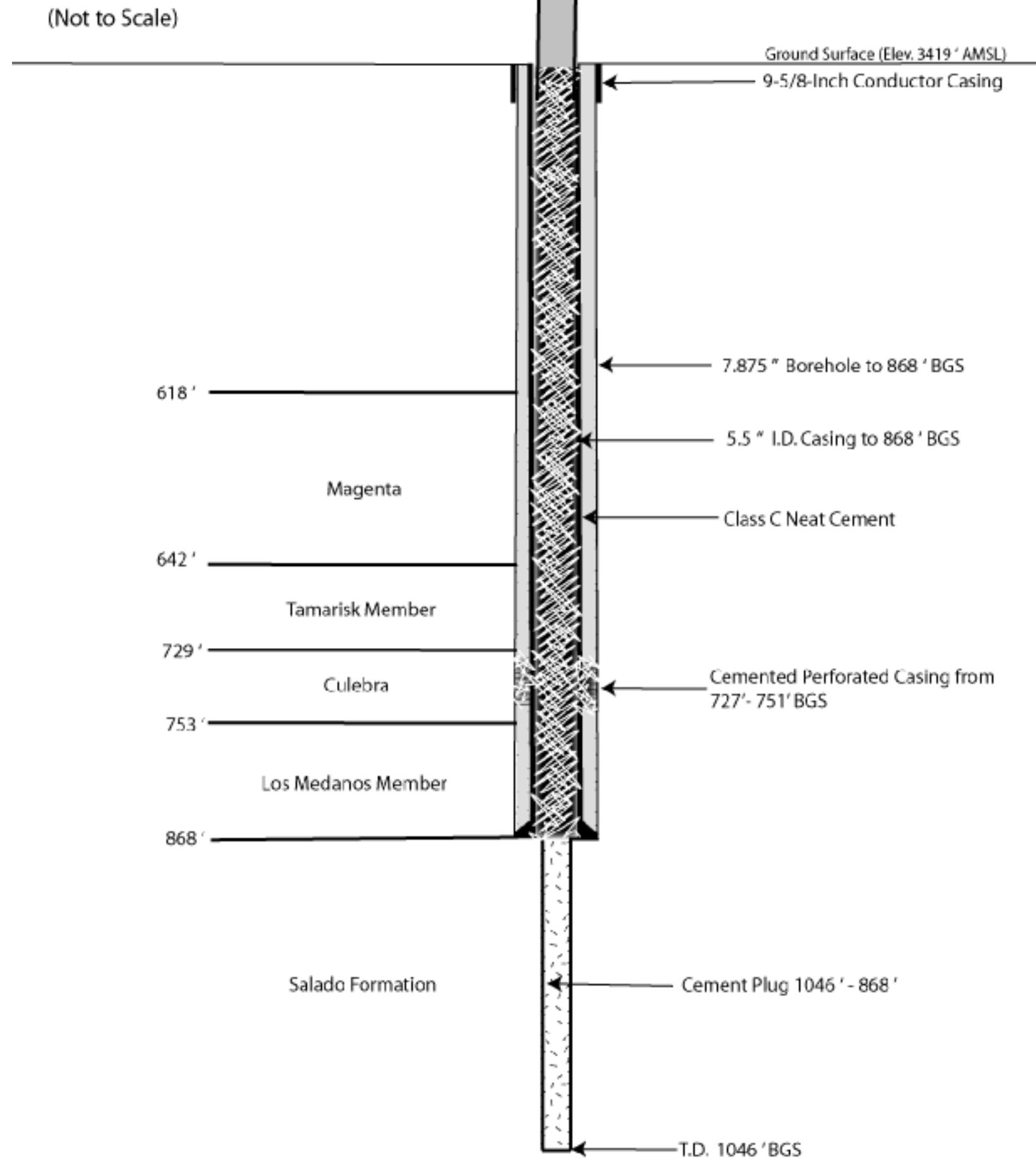
Basic Data Report for Well Plugging and Abandonment and Reconfiguration Activities for Fiscal Year 2005

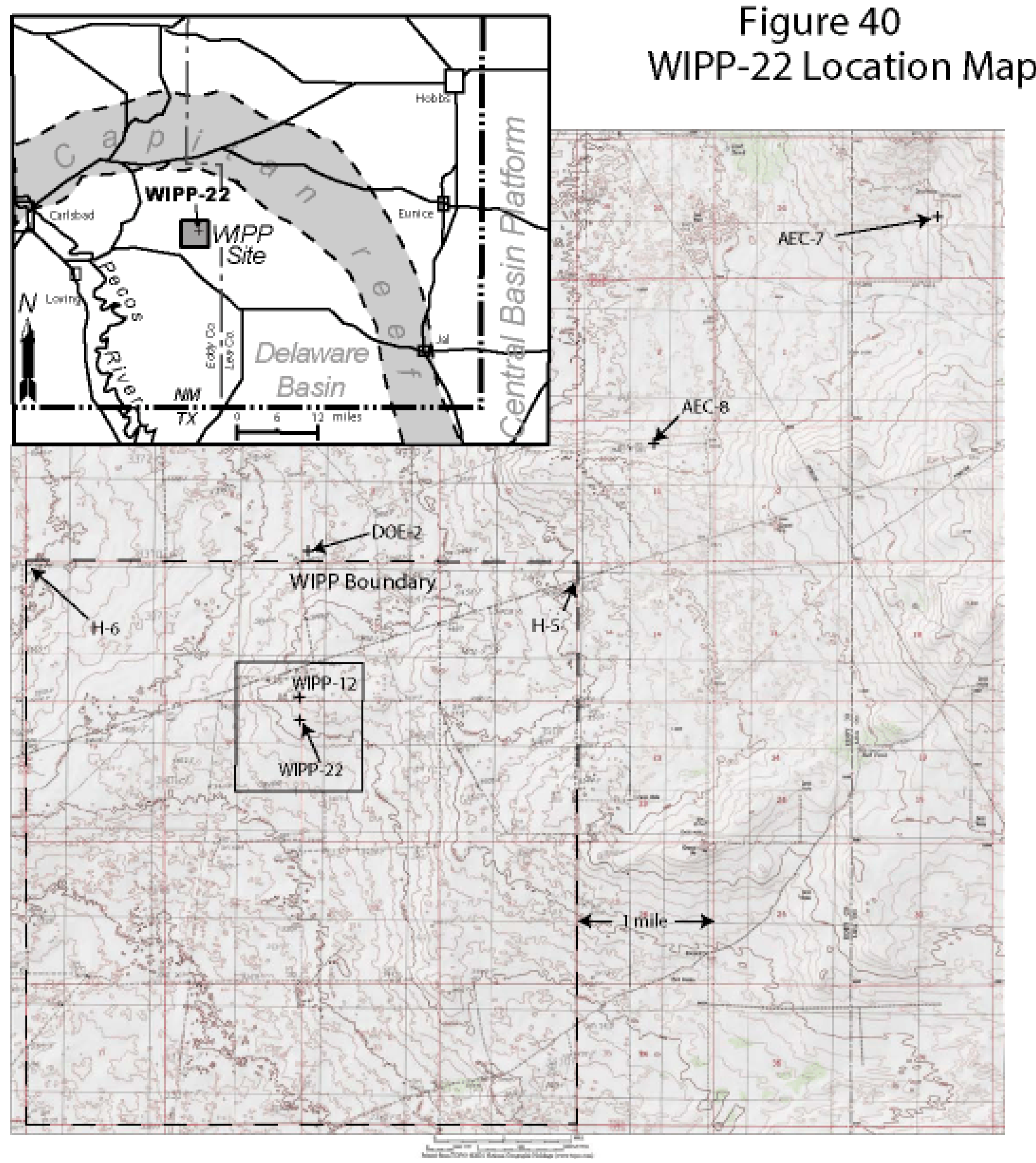


Basic Data Report for Well Plugging and Abandonment and

Reconfiguration Activities for Fiscal Year 2005

DOE/WIPP 05-3326

Figure 41

Construction of Well WIPP-22

Before P\&A

(Not to Scale)

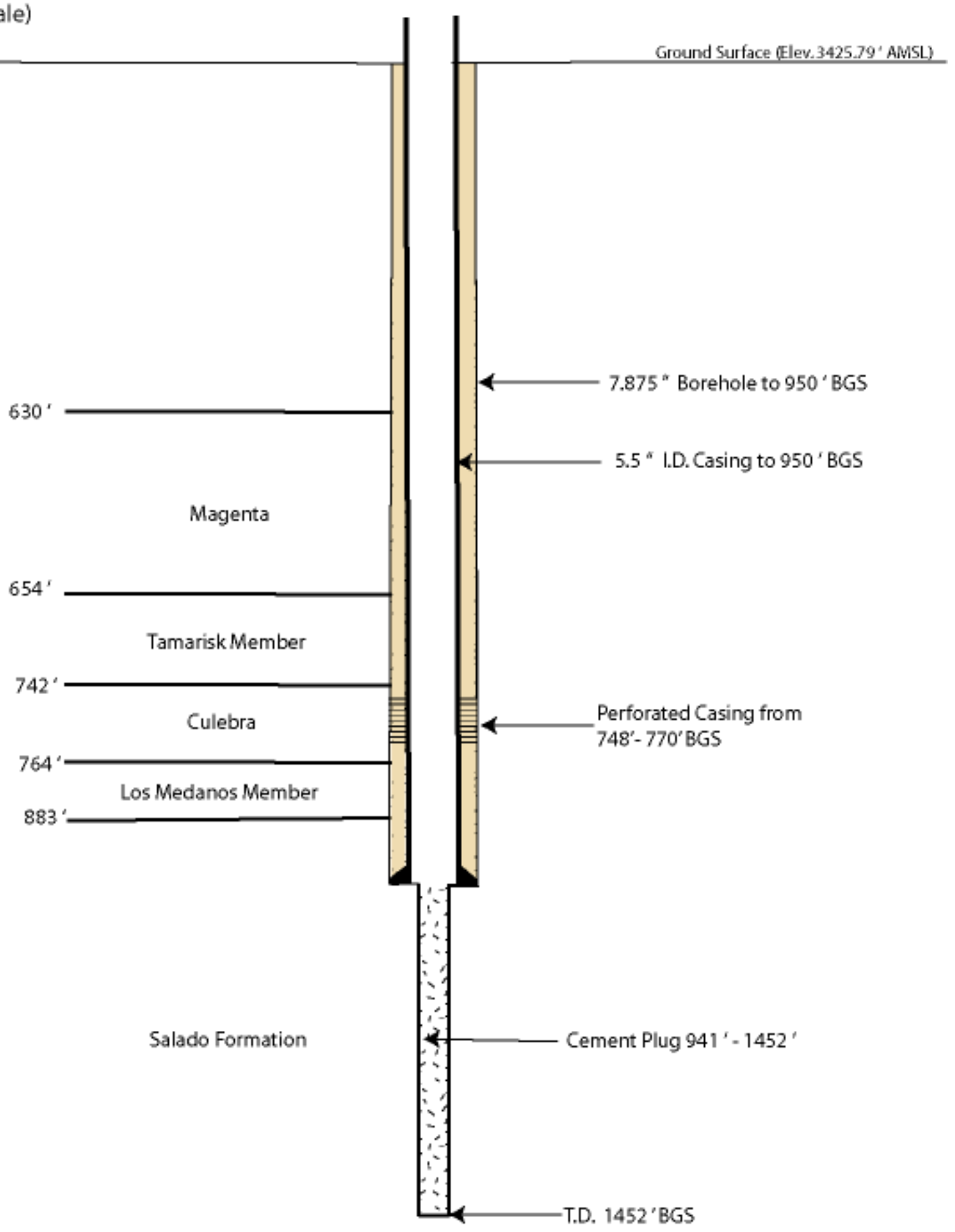




\section{Basic Data Report for Well Plugging and Abandonment and Reconfiguration Activities for Fiscal Year 2005

Figure 42

Construction of Well WIPP-22

After P\&A

(Not to Scale)

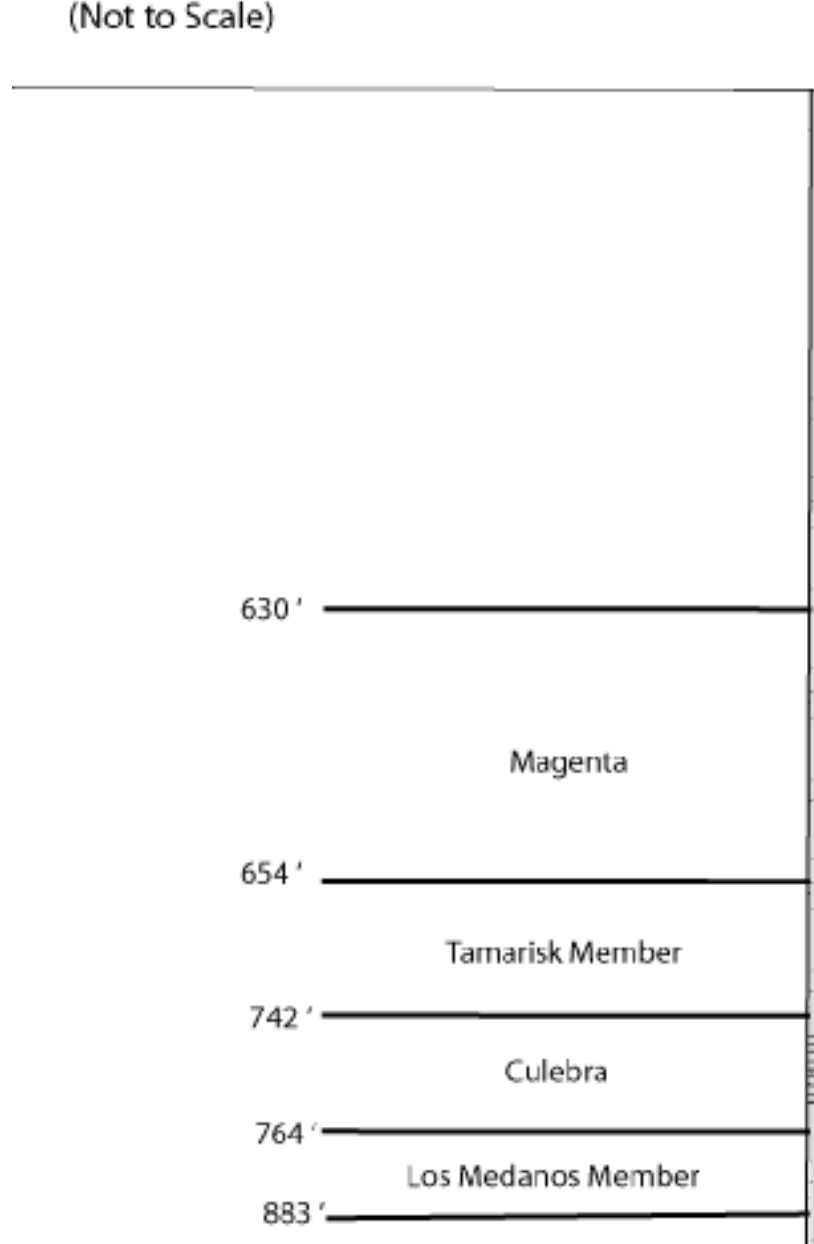

Salado Formation

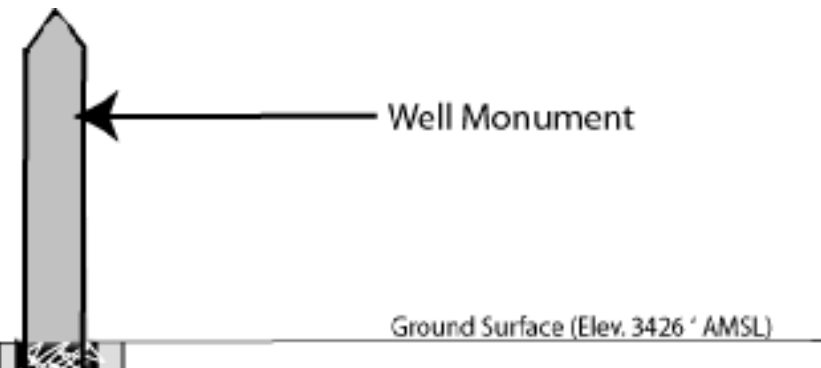

$\longleftarrow$ 7.875 "Borehole to 950 'BGS

$5.5^{*}$ I.D. Casing to 950 ' BGS

Class C Neat Cement
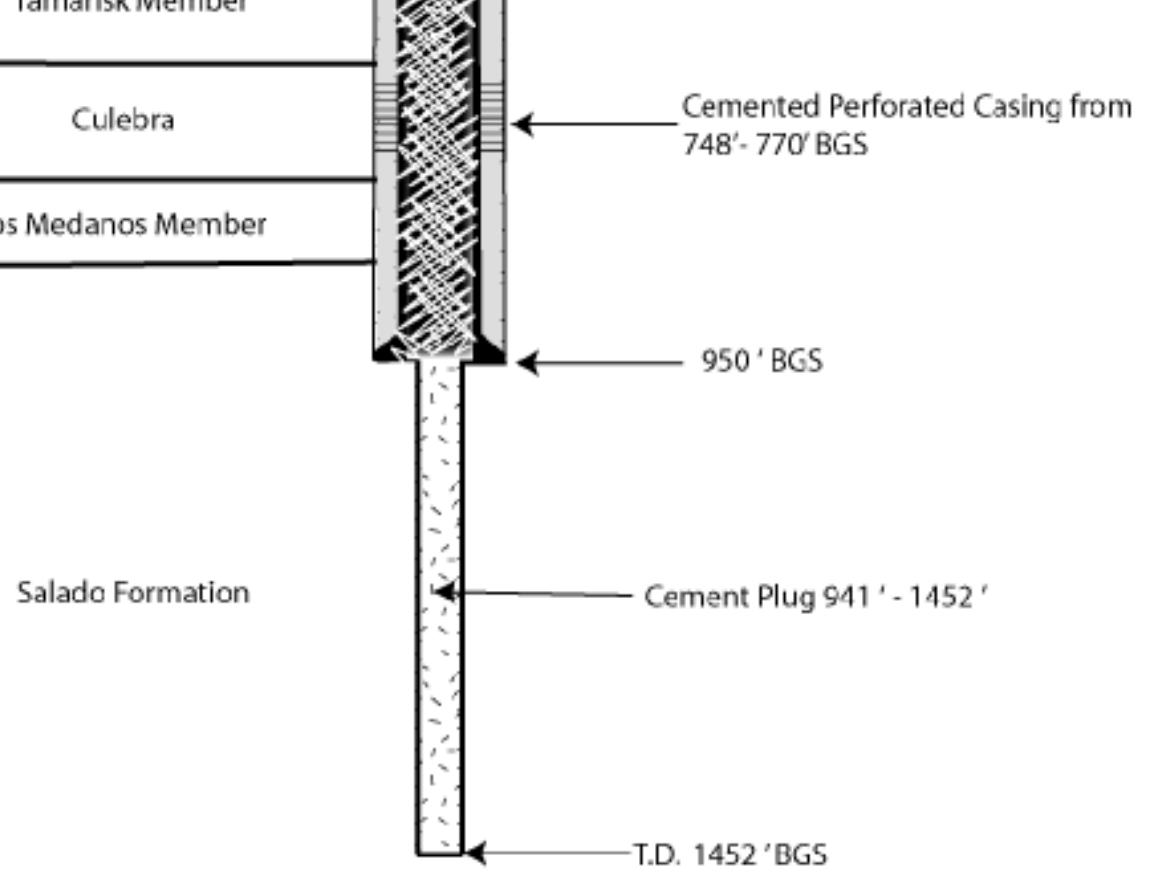


\section{Basic Data Report for Well Plugging and Abandonment and Reconfiguration Activities for Fiscal Year 2005 DOE/WIPP 05-3326}

\subsection{WELL WIPP-18}

Well WIPP-18 is located in Section 20, Township 22 South, Range 31 East, in eastern Eddy County, New Mexico and was drilled in March 1978 (Figure 43). The borehole was drilled to a depth of 1,060 feet bgs. After drilling, the borehole was left open, uncased, and filled with brine or brine mud until 1985. In 1985, the borehole was cleaned and reamed to a 7.875-inches diameter and a 5.5-inch casing was cemented to 1,050 feet in the Salado Formation, leaving a cement plug in the bottom of the hole from 1,050 to 1,060 feet bgs. After the casing was set, the borehole was perforated from 784 to 806 feet bgs. In March 2001, the well was fitted with an inflatable bridge plug (PIP) at a depth of 713.2 feet bgs, just below the Magenta Member. Following the installation of the bridge plug, the well was perforated at the Magenta interval from 676 to 702 feet bgs (Figure 44) (Saulnier et al., 1987).

Well WIPP-18 was a dual-completion well being used to monitor hydrostatic head in the Magenta Member of the Rustler Formation. The objective under the FY 2005 program was to reconfigure Well WIPP-18 as a Magenta-only monitor well by removing the packer and cementing up to the Magenta perforations. The activities for this well occurred May 30-31, 2005.

The removal of the packer and preparing the well was performed as described in Section 2.0 of this report. The well was first scraped and circulated down to the packer elevation. The packer was removed without incident, then the remaining casing was scraped and circulated to a depth of 1,050 feet bgs. Following packer removal and well preparation, 47.25 cubic feet of cement was pumped into the well to a depth 20 feet below the Magenta perforations for continued monitoring of this zone (Figure 45).

\subsection{H-5 WELL PAD}

The $\mathrm{H}-5$ well pad is located 1,007 feet from the north line, 234 feet from the east line, in Section 15, Township 22 South, Range 31 East in Eddy County, New Mexico (Figure 46). The pad consists of three wells $(\mathrm{H}-5 \mathrm{a}, \mathrm{H}-5 \mathrm{~b}$, and $\mathrm{H}-5 \mathrm{c})$ that were drilled in 1978 and completed in the Culebra Member of the Rustler Formation (Hydro Geo Chem, Inc. 1985). Later, well H-5c was reconfigured as a dual-completion well used to monitor the Magenta. The objective for the FY 2005 program for this pad was to reduce the number of wells at this location to one Culebra well and one Magenta well. Well plugging and reconfiguration activities at this location occurred May 31-June 11, 2005. 


\section{Basic Data Report for Well Plugging and Abandonment and Reconfiguration Activities for Fiscal Year 2005

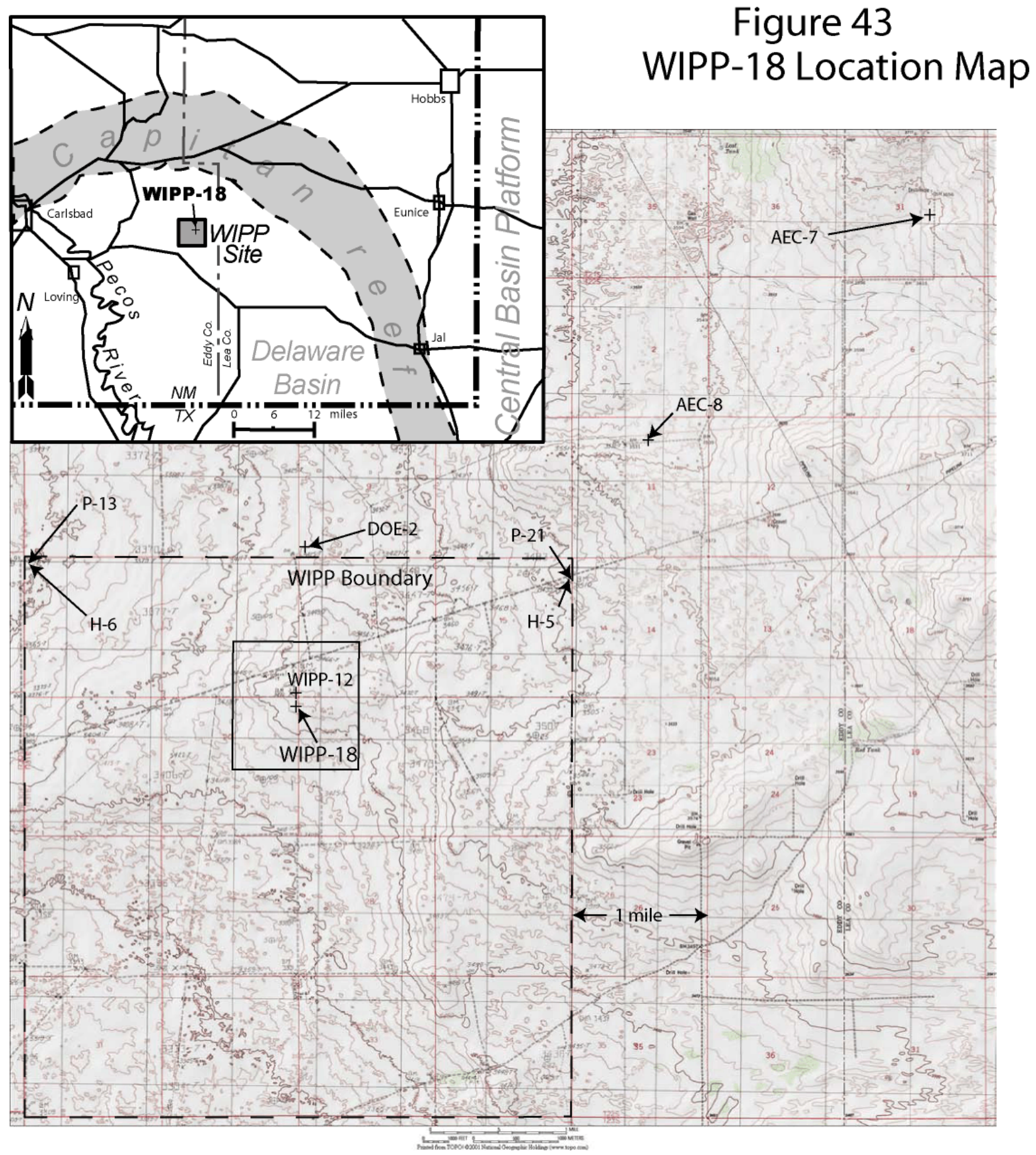




\section{Basic Data Report for Well Plugging and Abandonment and Reconfiguration Activities for Fiscal Year 2005

Figure 44

Construction of Well WIPP-18

Before Reconfiguration

(Not to Scale)

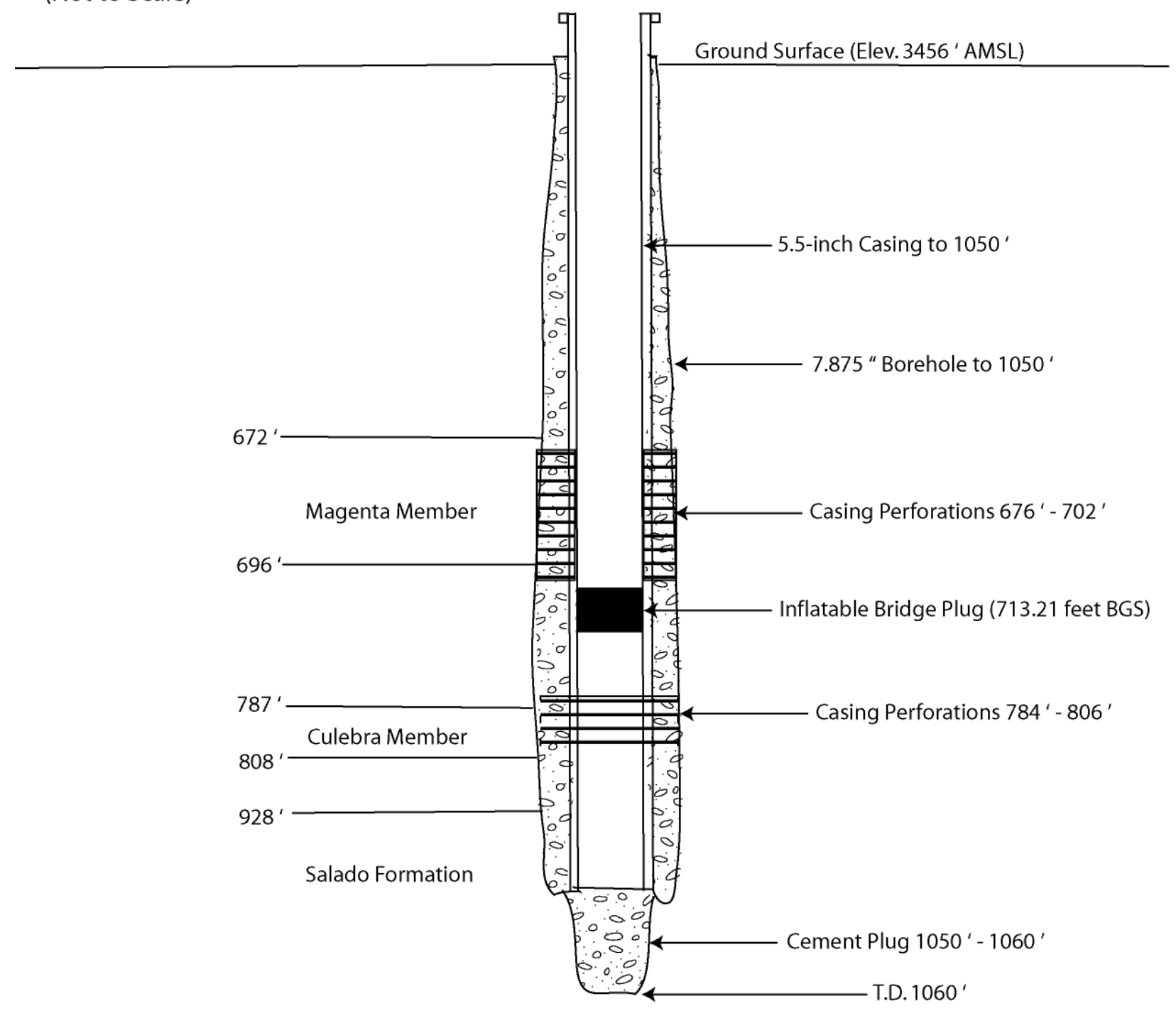




\section{Basic Data Report for Well Plugging and Abandonment and Reconfiguration Activities for Fiscal Year 2005

Figure 45

Construction of Well WIPP-18

After Reconfiguration

(Not to Scale)

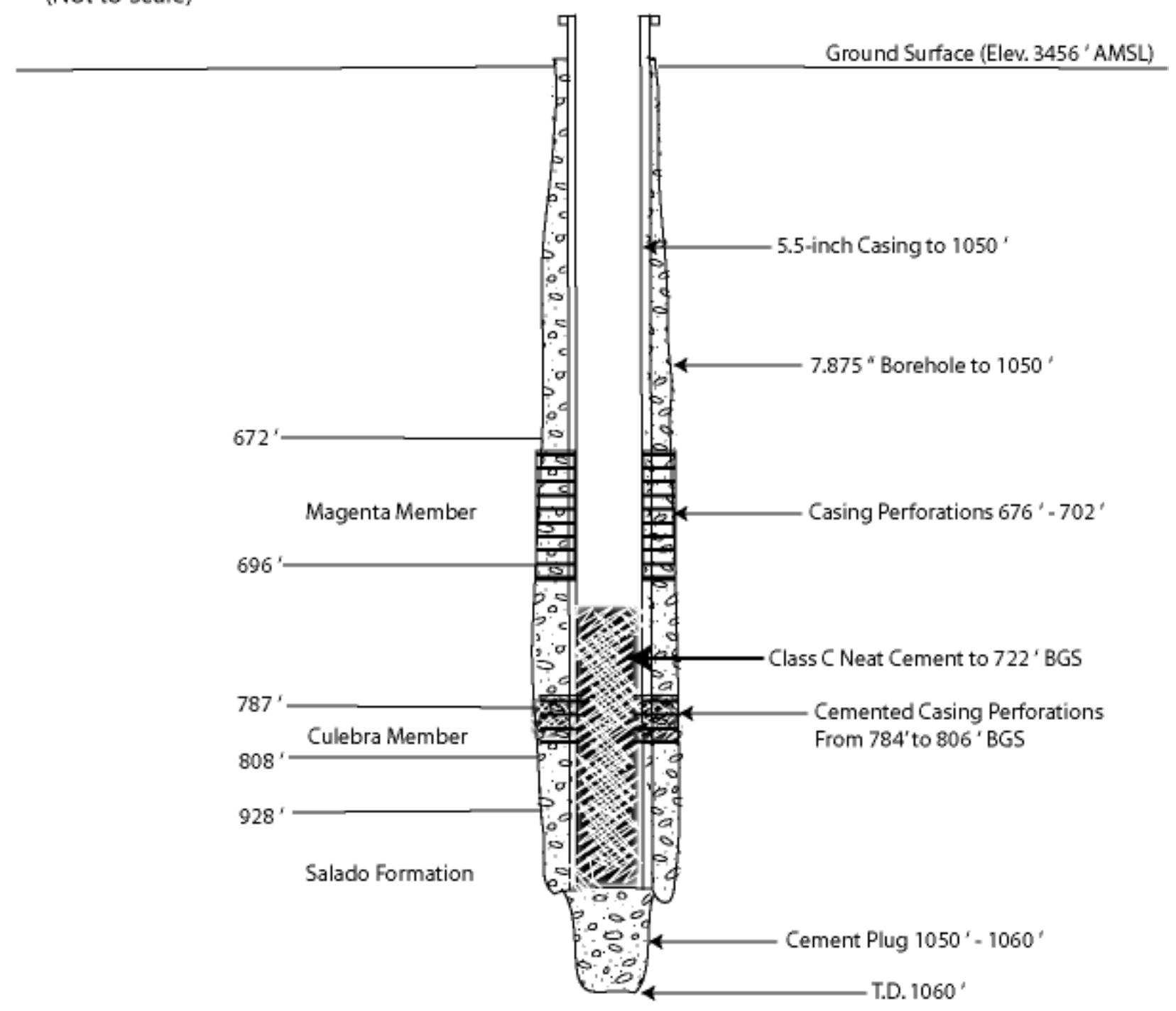




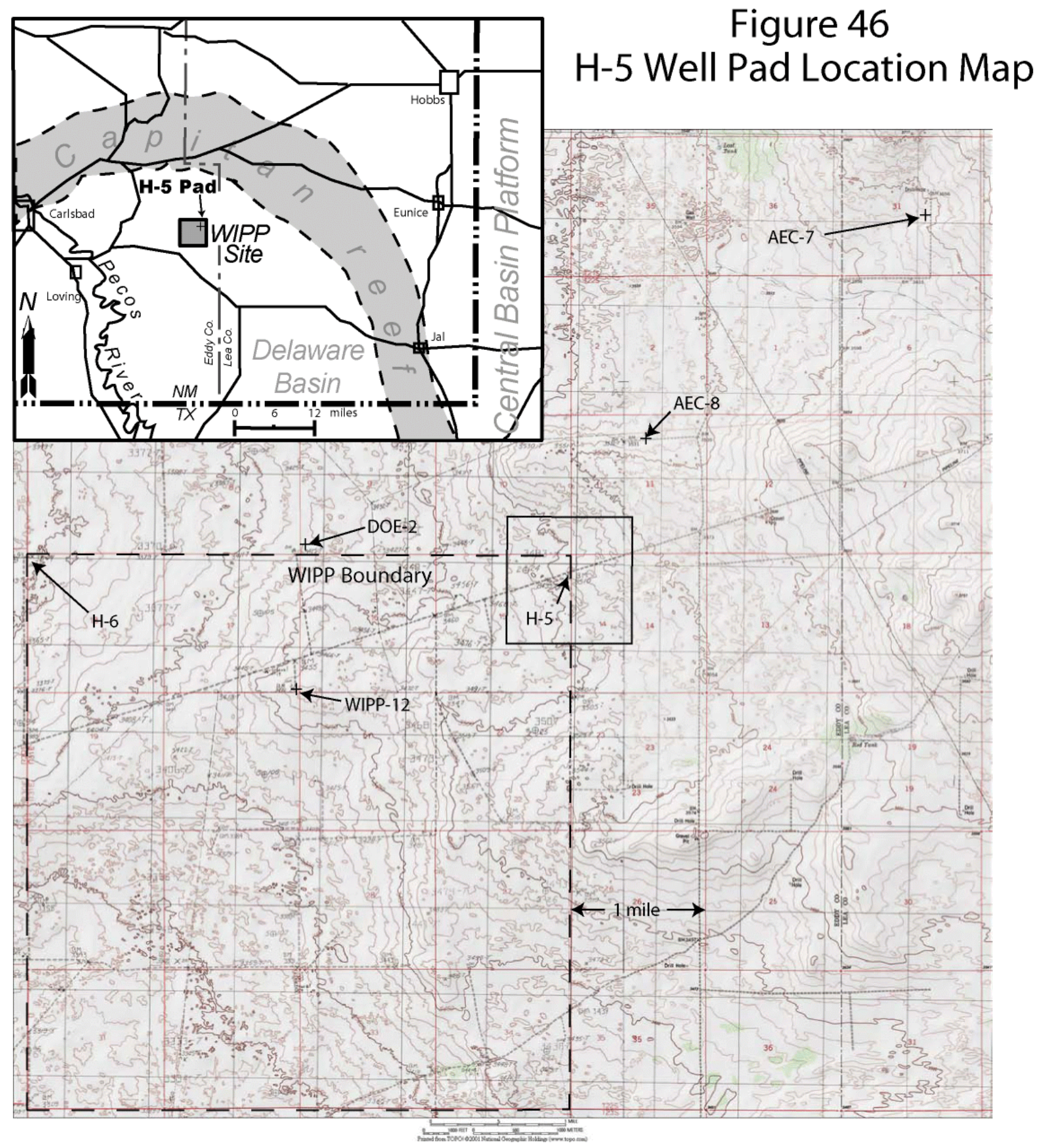




\section{Basic Data Report for Well Plugging and Abandonment and Reconfiguration Activities for Fiscal Year 2005 \\ DOE/WIPP 05-3326}

\subsection{Well H-5c}

Well $\mathrm{H}-5 \mathrm{c}$ was completed with 5.5 -inch casing cemented to a depth of 1,024 feet bgs and a 4.75-inch open hole to a total depth of 1,076 feet bgs. In 1981, the casing in well $\mathrm{H}-5 \mathrm{c}$ was perforated from 895 to 925 feet bgs to provide communication with the Culebra, and an inflatable bridge plug was set at 935 feet bgs to separate the Culebra from the underlying open portion of the hole (Hydro Geo Chem, Inc. 1985). In 1986, the casing in well $\mathrm{H}-5 \mathrm{c}$ was perforated from 788 to 812 feet bgs to provide communication to the Magenta. An inflatable packer was set at 836 feet bgs to separate the Culebra from the Magenta (Figure 47).

Well $\mathrm{H}-5 \mathrm{c}$ was used to monitor hydrostatic head in the Magenta Member of the Rustler Formation. The objective under the FY 2005 program was to reconfigure the dual-completion well $\mathrm{H}-5 \mathrm{c}$ as a Magenta-only monitor well. The two packers were removed without incident using a J-tool as described in Section 2.0 of this report. Following packer removal and well preparation, 45.15 cubic feet of cement was pumped into the well to a depth 20 feet below the Magenta perforations to allow continued monitoring of this zone (Figure 48).

\subsection{Well H-5a}

Well $\mathrm{H}-5 \mathrm{a}$ was completed with 5.5 -inch casing cemented in place from ground surface to 774 feet bgs. After setting the casing, a 4.75-inch open hole was drilled from 774 feet bgs to 897 feet bgs. A 2.25-inch hole was cored from 897 feet bgs to a total depth of 934 feet bgs. Following well construction, an inflatable PIP was set at 895 feet bgs with 1.5-inch galvanized tubing extending to the surface (Figure 49) (Hydro Geo Chem, Inc. 1985). The purpose of this well was to monitor hydrostatic head in the Culebra. The objective under the FY 2005 program was to plug and abandon this well and remove it from the monitoring network.

Activities at this well were similar to those at the $\mathrm{H}-6 \mathrm{c}$ location, due to similar construction. Because the PIP was set on galvanized pipe instead of steel tubing, removing the PIP assembly (packer and pipe) was difficult due to excessive corrosion. Due to the metal fatigue of the pipe threads and the pipe section, the pipe was removed in pieces using a overshot tool and grapple. Additionally, several hundred feet of cable and electrical wire were bound in the hole that made removal difficult (Photos 20 and 21 ). The packer was moved up to a depth of 474 feet bgs before getting stuck in the well.

After several attempts to remove the packer and after removal of approximately 777 feet of galvanized pipe and transducer wire and cable, the decision was made, and agreed to by the NMOSE, to drive the packer as far as possible into the well.

Twenty-two drill collars were loaded onto the pipe and packer inside the well and the assembly was driven as far into the well as possible. The maximum depth that could be achieved was 603 feet bgs, estimating the depth of the packer bottom at 897 feet bgs, 


\section{Basic Data Report for Well Plugging and Abandonment and Reconfiguration Activities for Fiscal Year 2005

the transition to the 2.25-inch hole. After driving the packer to depth, the well was circulated in preparation for cementing. The well was filled with 81 cubic feet of Class $C$ Neat cement slurry, filling the well to the surface. Upon completion of the cementing, a well monument was fixed to the well location in accordance to BLM requirements (Figure 50). 


\section{Basic Data Report for Well Plugging and Abandonment and Reconfiguration Activities for Fiscal Year 2005

Figure 47

Construction of Well $\mathrm{H}-5 \mathrm{C}$

Before Reconfiguration

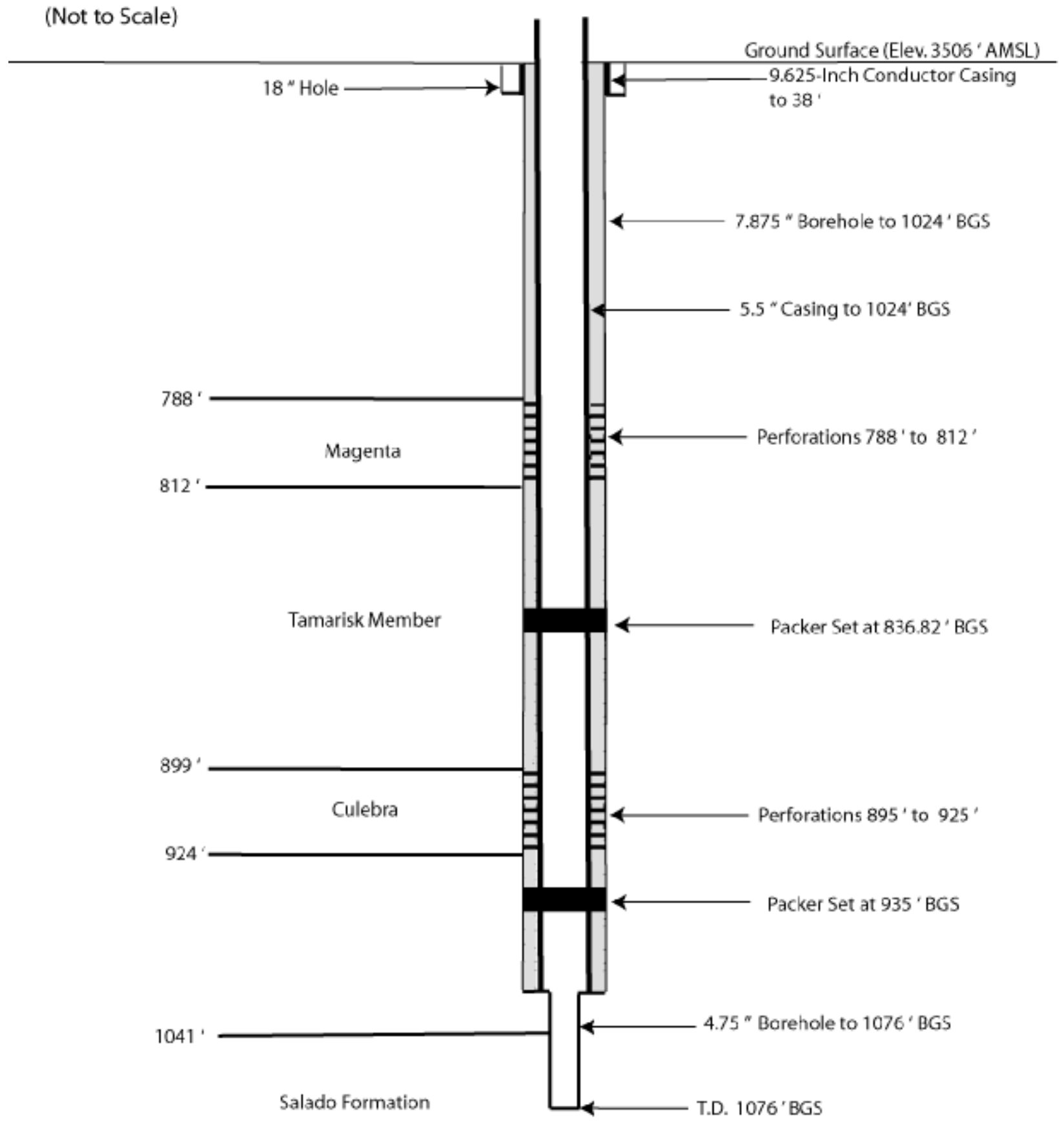




\section{Basic Data Report for Well Plugging and Abandonment and Reconfiguration Activities for Fiscal Year 2005

Figure 48

Construction of Well H-5C

After Reconfiguration

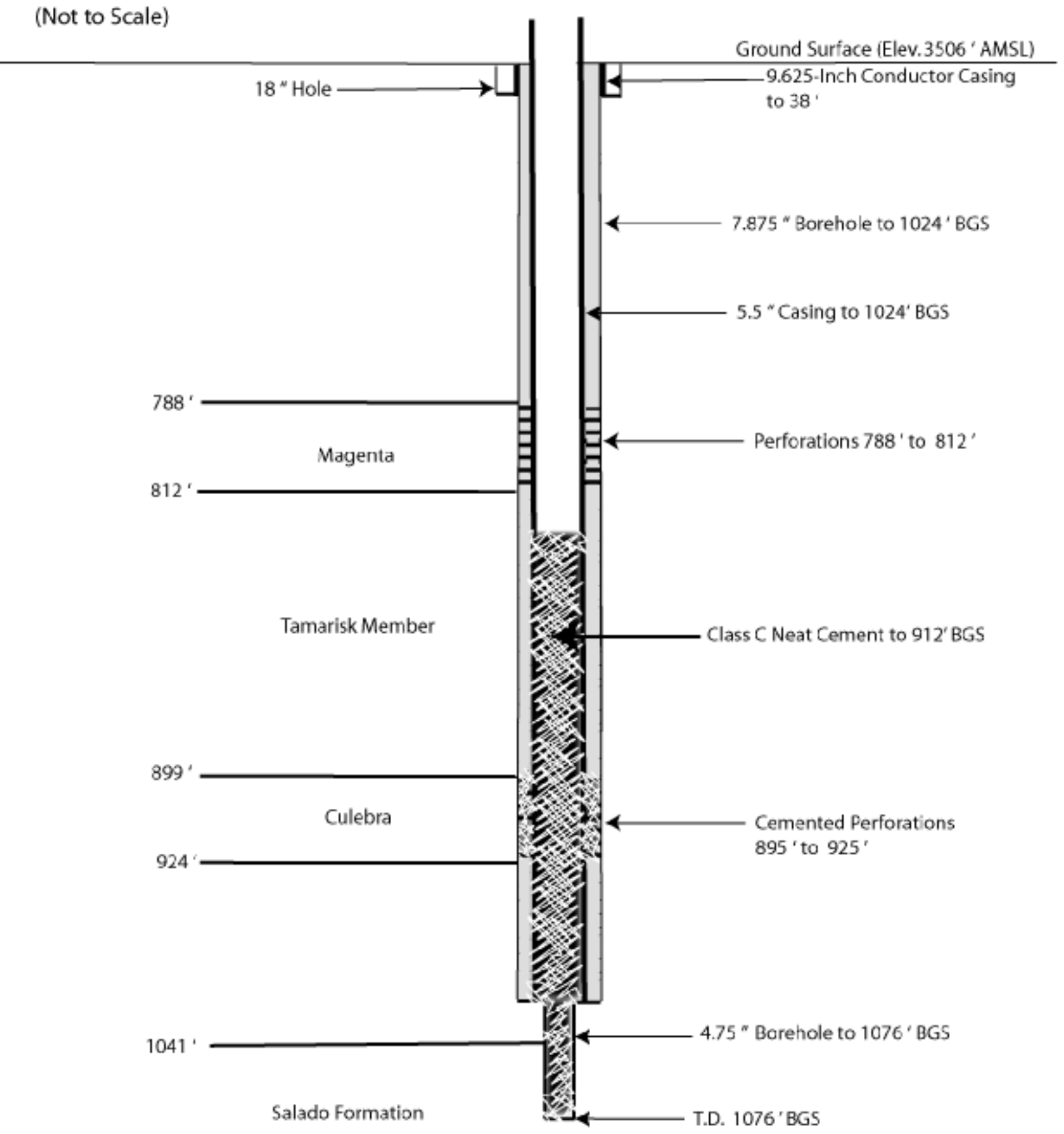




\section{Basic Data Report for Well Plugging and Abandonment and Reconfiguration Activities for Fiscal Year 2005

Figure 49

Configuration of Well H-5a

Before P\&A

(Not to Scale)

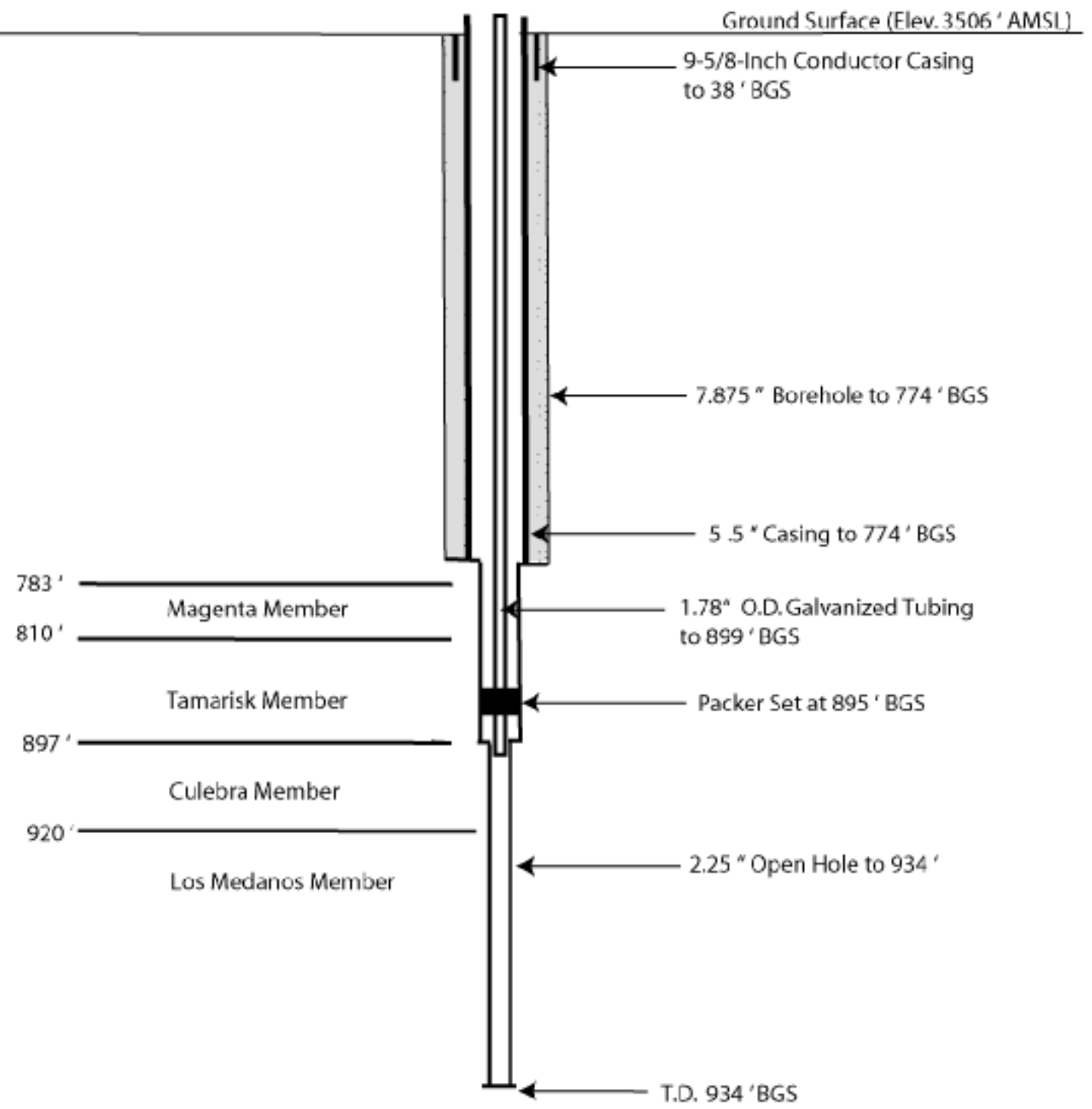




\section{Basic Data Report for Well Plugging and Abandonment and Reconfiguration Activities for Fiscal Year 2005

Figure 50

Configuration of Well $\mathrm{H}-5 \mathrm{a}$

After P\&A

(Not to Scale)
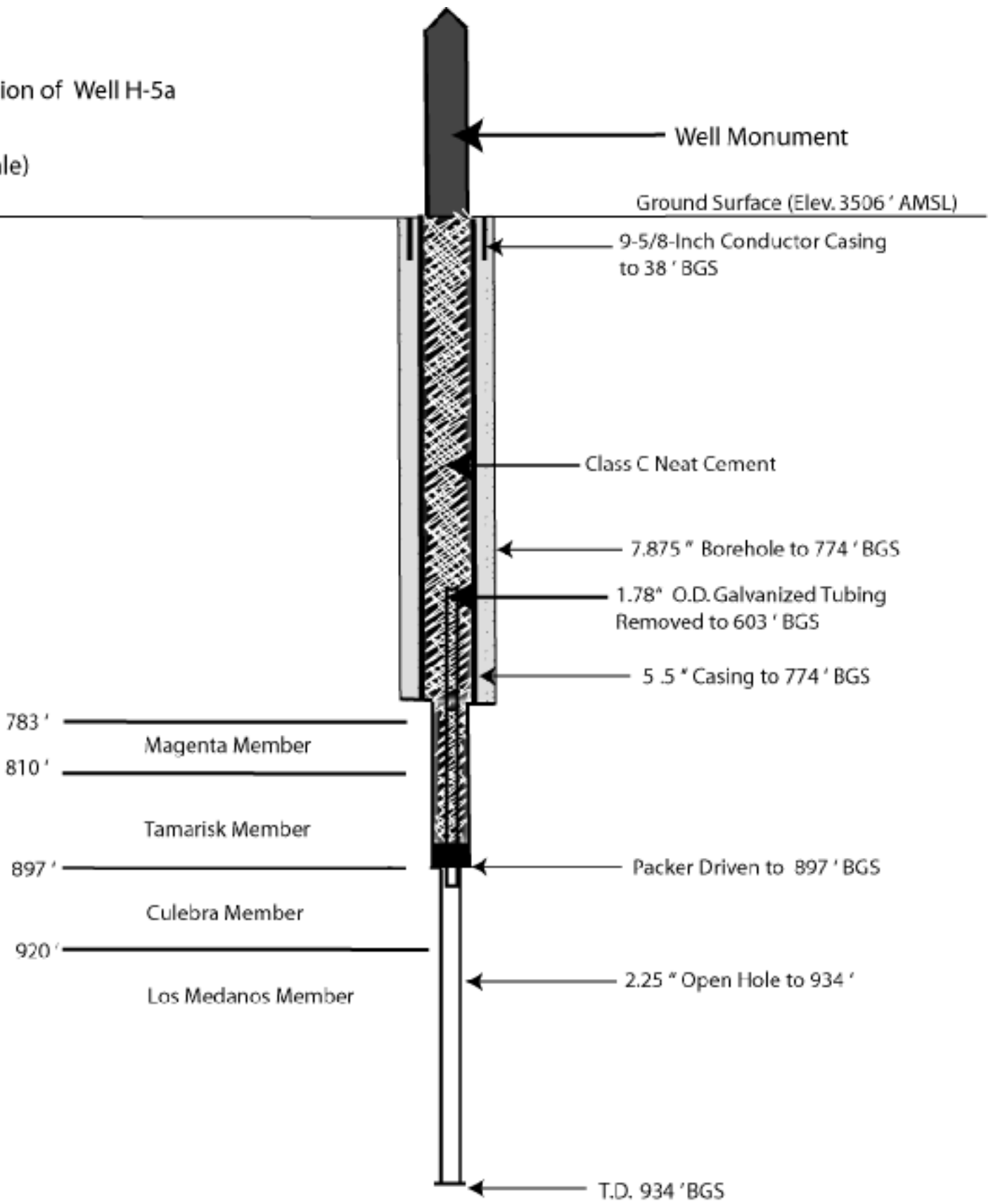


\section{Basic Data Report for Well Plugging and Abandonment and Reconfiguration Activities for Fiscal Year 2005 \\ DOE/WIPP 05-3326}

\subsection{H-3 WELL PAD}

The $\mathrm{H}-3$ well pad is located approximately one-half mile from the center of the WIPP site in Section 29, Township 22 South, and Range 31 East (Figure 51). The well pad contained four wells $(\mathrm{H}-3 \mathrm{~b} 1, \mathrm{H}-3 \mathrm{~b} 2, \mathrm{H}-3 \mathrm{~b} 3, \mathrm{H}-3 \mathrm{~d})$ prior to the $\mathrm{FY} 2005$ program. These were completed at various intervals to investigate geologic and hydraulic properties and perform aquifer and tracer testing. Well work-over activities at this location during the FY 2005 program occurred June 11-24, 2005.

\subsection{Well H-3b3}

Well H-3b3 was drilled in 1983 as an exploratory borehole to investigate hydraulic properties. The borehole for well $\mathrm{H}-3 \mathrm{~b} 3$ was drilled to a depth of 730 feet bgs and cased to a depth of 673 feet bgs (Figure 52) (SNL and Intera Technologies 1986). The borehole was left open across the Culebra. The purpose of this well was to monitor hydrostatic head in the Culebra. The objective under the FY 2005 program was to plug and abandon well $\mathrm{H}-3 \mathrm{~b} 3$ and remove it from the monitoring network.

This well contained no packer or other elements, so the decommissioning process was straightforward: scrape, circulate, cement, and monument. Work for this well occurred June 11-12, 2005.

The well was scraped to a depth of 672 feet bgs as described in Section 2.0 of this report. Following scraping, the well was circulated to total depth, followed by cementing the well to the surface using tremmie pipe as presented in Section 2.0 using 108 cubic feet of Class $C$ Neat cement slurry, concluding with fixing a monument at the location according to BLM requirements (Figure 53).

\subsection{Well H-3b1}

Well H-3b1 was drilled under the direction of the USGS and was completed August 12, 1976. This well was drilled to a total depth of 894 feet bgs and completed with 6.625-inch casing. The well was subsequently perforated at three different intervals at the Magenta (564 to 592 feet bgs), the Culebra (675 to 703 feet bgs), and the Rustler/Salado Formations contact (813 to 837 feet bgs). The well was then fitted with mechanical bridge plugs separating these intervals (Figure 54) (SNL and Intera Technologies 1986).

Despite all the different perforated intervals, the Magenta was the only interval being monitored before reconfiguring this well. The plan for this well under the FY 2005 program was to remove all the bridge plugs and reconfigure the well as a single-completion location for Magenta monitoring. Work at this well occurred June 13-14, 2005. 
Basic Data Report for Well Plugging and Abandonment and Reconfiguration Activities for Fiscal Year 2005

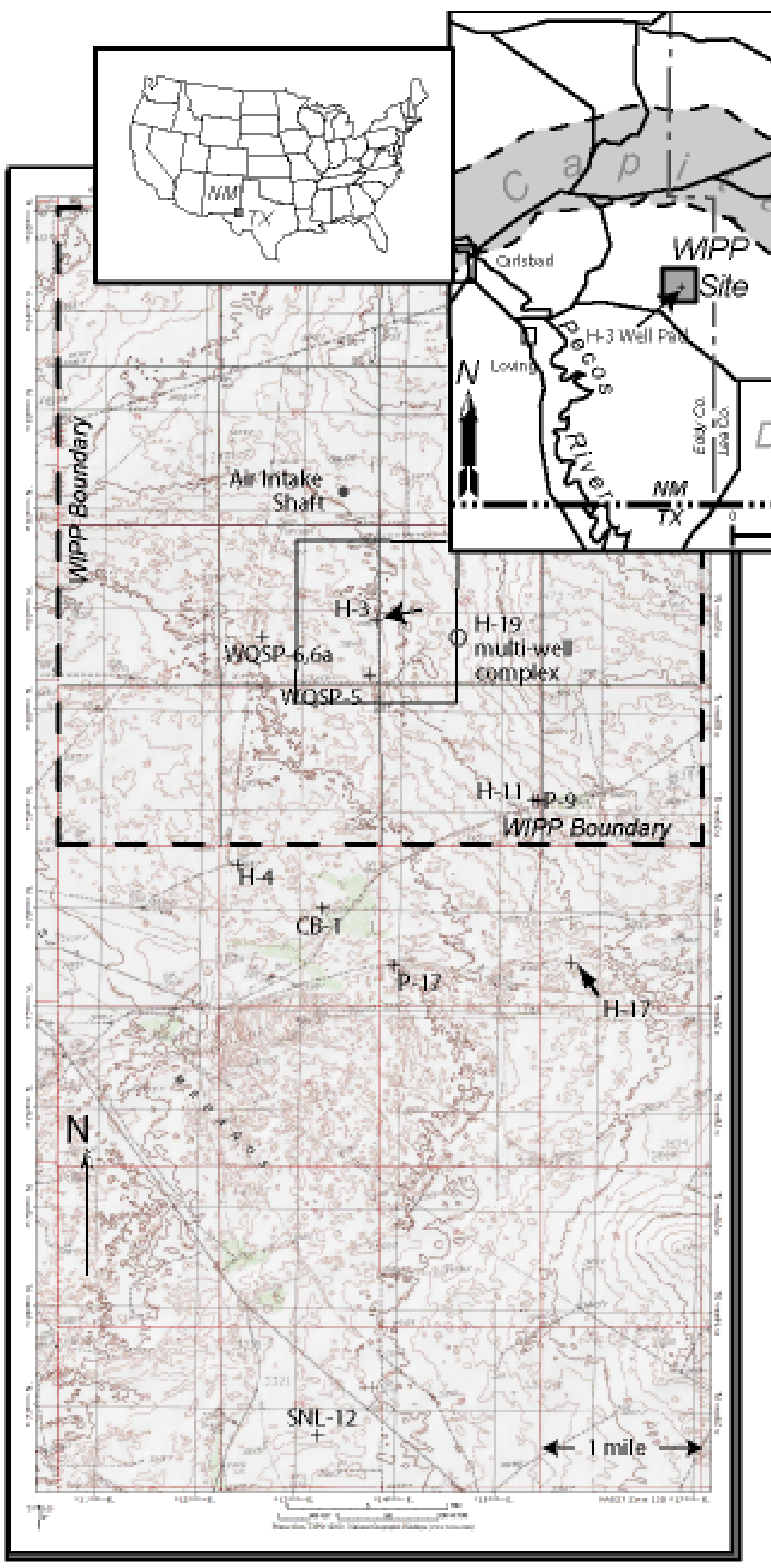

Figure 51

$\mathrm{H}-3$ Well Pad Location Map 
Basic Data Report for Well Plugging and Abandonment and

Reconfiguration Activities for Fiscal Year 2005

DOE/WIPP 05-3326

Figure 52

Construction of Well $\mathrm{H}-3 \mathrm{~b} 3$

Before P\&A

(Not to Scale)

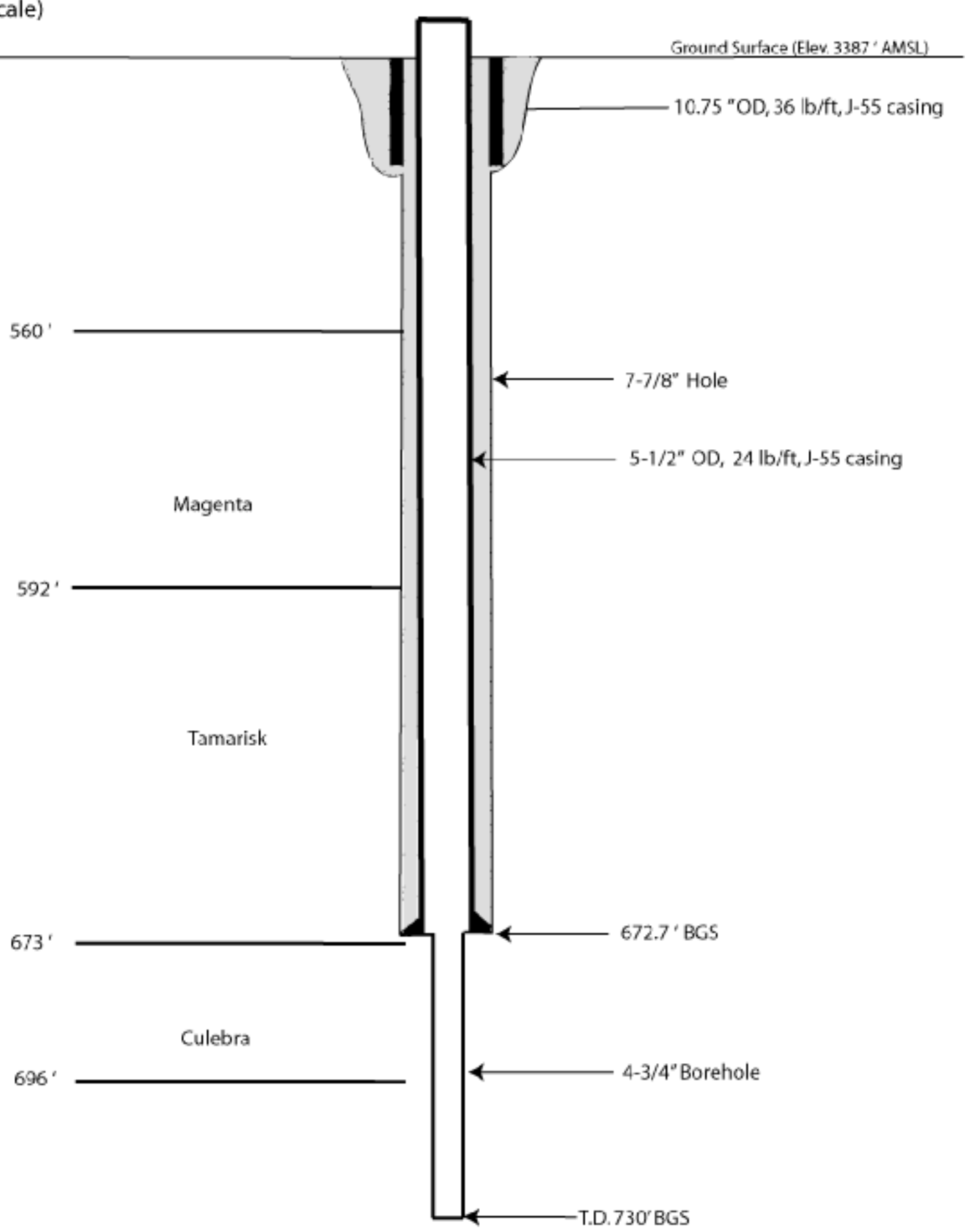




\section{Basic Data Report for Well Plugging and Abandonment and Reconfiguration Activities for Fiscal Year 2005

Figure 53

Construction of Well $\mathrm{H}-3 \mathrm{~b} 3$

After P\&A

(Not to Scale)

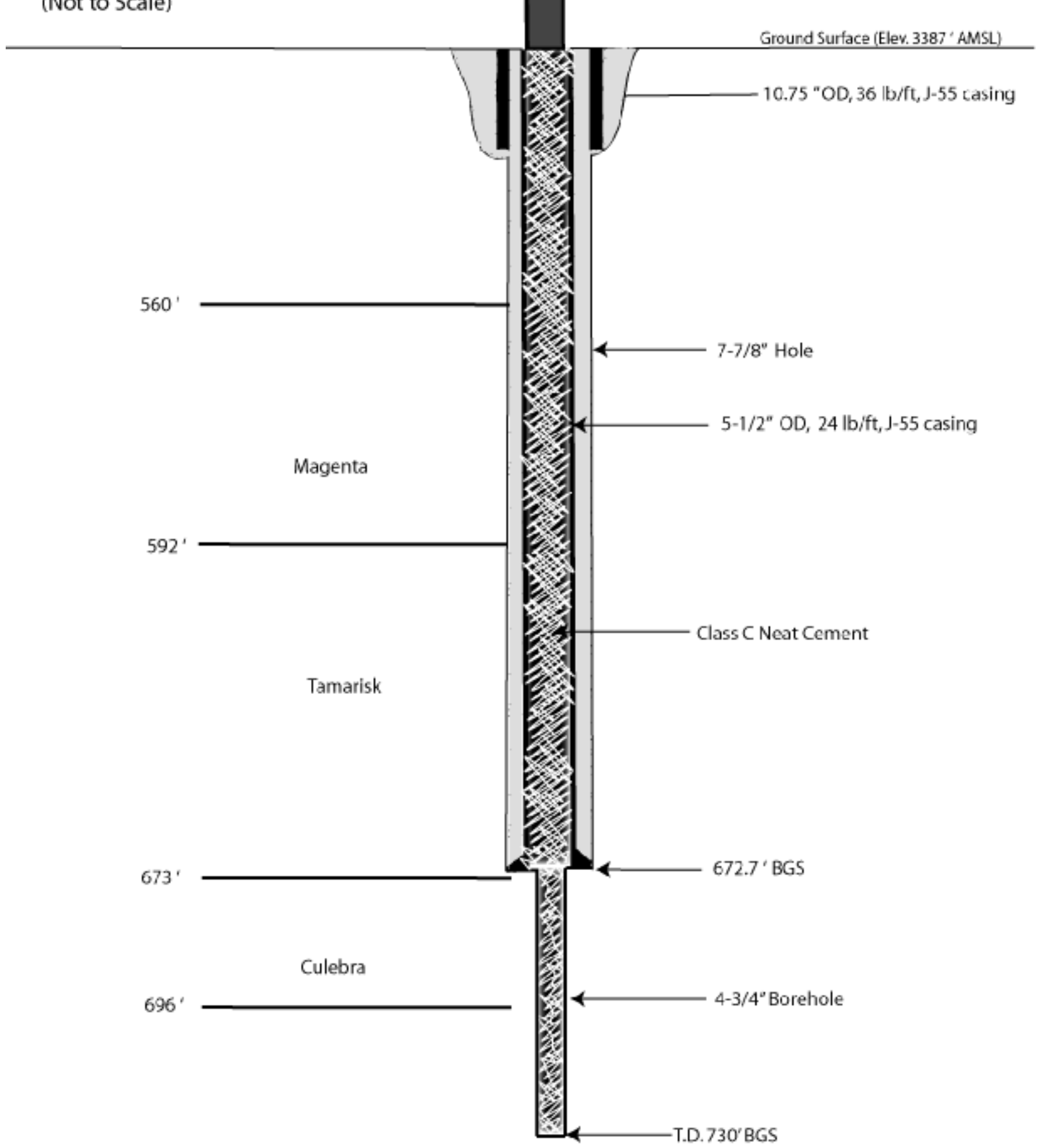




\section{Basic Data Report for Well Plugging and Abandonment and Reconfiguration Activities for Fiscal Year 2005

Figure 54

Construction of Well H-3b1

Before Reconfiguration

figuration (Not to Scale)

Total Depth 894 feet BGS

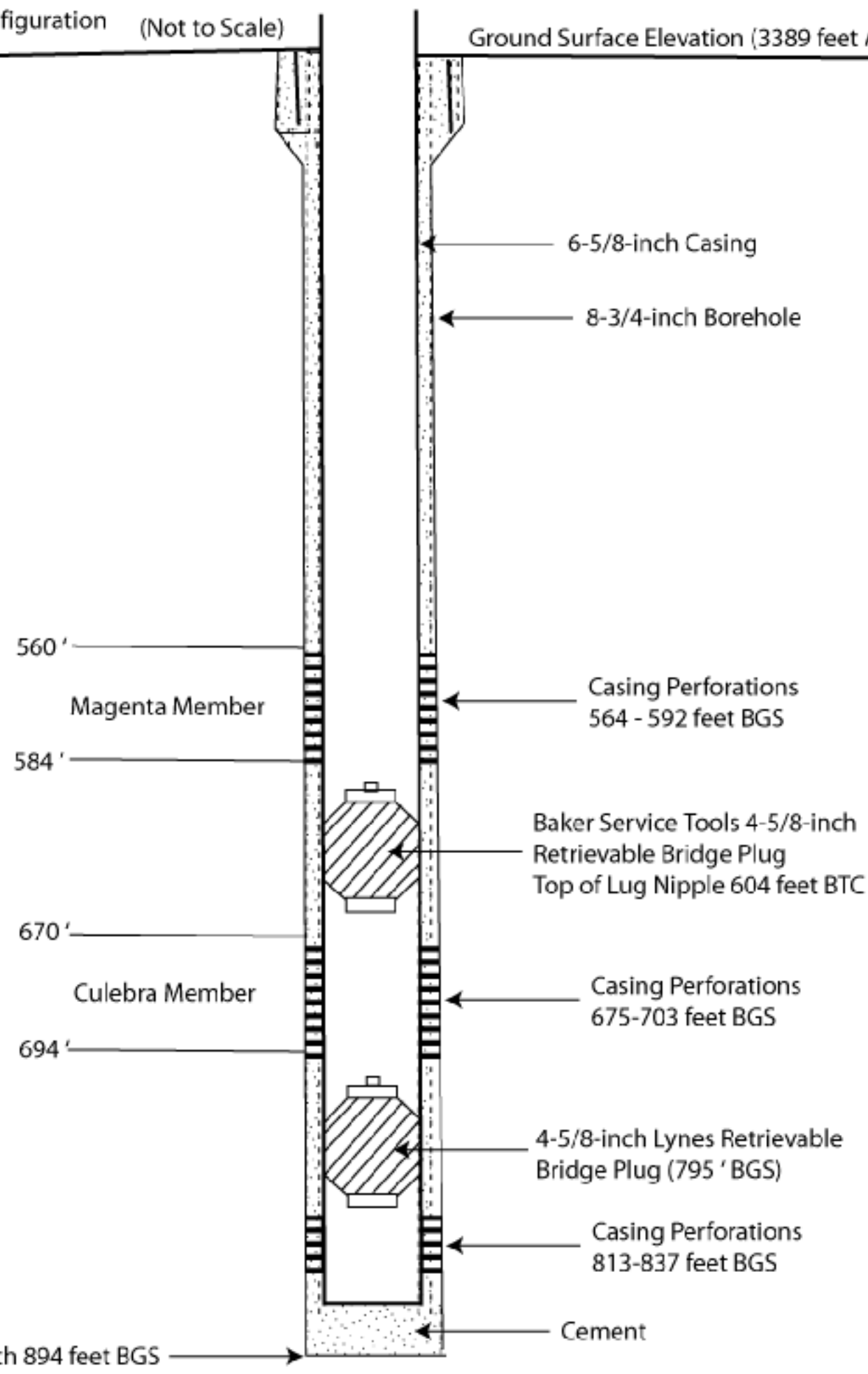




\section{Basic Data Report for Well Plugging and Abandonment and Reconfiguration Activities for Fiscal Year 2005 \\ DOE/WIPP 05-3326}

Two mechanical bridge plugs were removed from this well (Photos 22 and 23). The well was scraped down to the first packer (actually at 634 feet bgs) and the spall circulated from the well. The bridge plug was retrieved using a J-tool as described in Section 2.0 without incident. Following removal of the upper bridge plug, the well was scraped to the top of the lower bridge plug followed by circulation. The lower bridge plug was encountered at a depth of 781 feet bgs, not 795 feet bgs as documented. Following retrieval of the lower packer, the remaining casing was scraped and circulated in preparation for cementing operations. Cement was placed using tremmie methods as described in Section 2.0. A total of 54 cubic feet of Class $C$ Neat cement slurry was used to fill the well to a depth of 612 feet bgs (Figure 55).

\subsection{Well H-3d}

Well H-3d was drilled in April 1987 as an observation well for the Forty-niner Member of the Rustler Formation and the Dewey Lake Redbeds. The well was completed by setting an inflatable packer with tubing in the upper anhydrite of the Forty-niner. No casing or well screen were used for well completion, leaving an open hole (Stensrud et al., 1990).

Well H-3d was drilled to a depth of approximately 555 feet bgs in the lower part of the Forty-niner Member of the Rustler Formation. After drilling and cleaning the borehole of cutting, a Baker Service Tools 5.625-inch PIP was installed from 515 to 518 feet bgs in the upper anhydrite of the Forty-niner Member. Additionally, 419 feet of 0.75 -inch PVC tubing was installed in the annulus for water-level access (Figure 56) (Stensrud et al., 1990).

Well $\mathrm{H}-3 \mathrm{~d}$ was used as an observation well to monitor the water levels since installation; however, later data indicated that the tubing in the well was pinched. The objective under the FY 2005 program was to remove the PIP assembly (packer and tubing), clean out the open borehole, cement up to a new well depth, and install a new PVC well at the Santa Rosa/Dewey Lake contact zone. Well reconfiguration at this location occurred in two stages: June 14-15, 2005 (well clean-out), and June 21-24, 2005 (setting the new well).

To begin the first phase, the PVC tubing was removed from the well using cable pulleys from the drilling rig (Photo 24). Twenty-five 20-foot sections of PVC tubing were removed from the borehole (500 linear feet). After removing the PVC tubing, an attempt at removing the 2.375 -inch tubing was made. It was obvious why water levels could no longer be obtained from this location from the onset of removing the tubing.

Initial tubing removal was attempted in the same manner as described for well AEC-8; however, the tubing separated in sections measuring from 6 feet to 6 inches. The tubing removal was accomplished, for the most part, using an overshot-grapple tool, 


\section{Basic Data Report for Well Plugging and Abandonment and Reconfiguration Activities for Fiscal Year 2005

Figure 55

Construction of Well $\mathrm{H}-3 \mathrm{~b} 1$

After Reconfiguration

(Not to Scale)
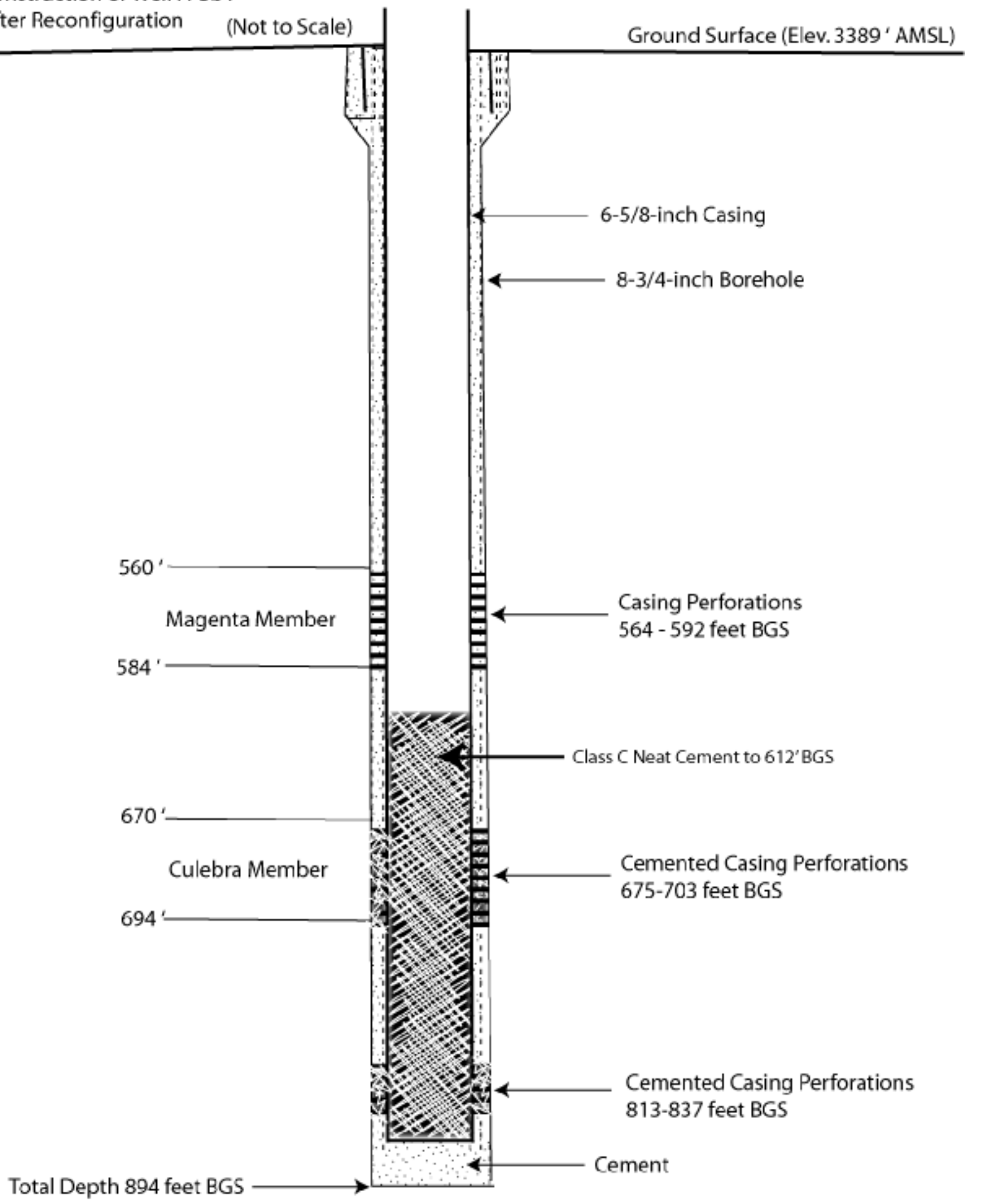


\section{Basic Data Report for Well Plugging and Abandonment and Reconfiguration Activities for Fiscal Year 2005

Figure 56

Construction of Well $\mathrm{H}-3 \mathrm{~d}$

Before Reconfiguration

(Not to Scale)

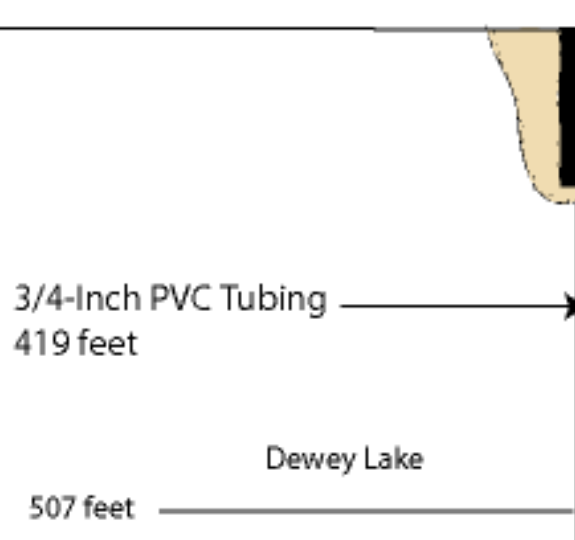

Forty-Niner Member

Forty-Niner Anhydrite

536 feet

546 feet

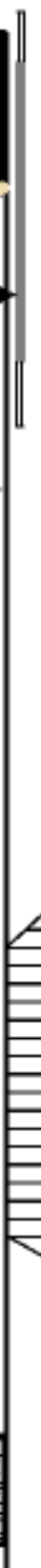

Ground Surface (Elev.3388 'AMISL)

8-5/8-Inch Surface Casing

0-39 feet (BGS)

2-3/8-Inch Tubing

7-7/8-Inch Rotary-Drilled

Uncased Borehole

Baker Service Tools 5-5/8-Inch PIP. Top of Element at 515.6 feet

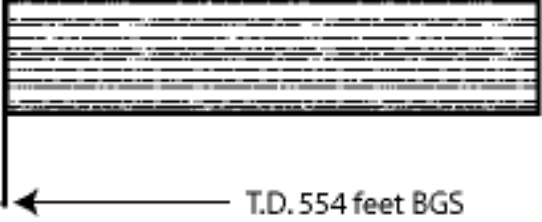




\section{Basic Data Report for Well Plugging and Abandonment and Reconfiguration Activities for Fiscal Year 2005 \\ DOE/WIPP 05-3326}

tripping in and out of the borehole removing sections at a time (Photo 25). During this process, it became apparent that the packer in the hole had failed and dropped further down the hole as the depth of tubing at one point was 528 feet bgs, thirteen feet below the reported depth. After fourteen hours over a day and a half, the decision was made to leave the packer in the hole at a depth of 528 feet bgs. The decision was coordinated with, and approved with, the NMOSE.

Following removal of the tubing, the borehole was circulated to clean the hole out as best as possible. Following circulation, the borehole was filled with 162 cubic feet of cement to a depth of 87 feet bgs. Once the cement was cured, work began on completing the well for a Santa Rosa/Dewey Lake monitor well.

The design depth of the new well was based on the Santa Rosa/Dewey Lake contact. This contact was defined by the stratigraphic description provided in Appendix $\mathrm{BH}$ of the Compliance Certification Application (U.S. DOE, 1996) for this well and confirmed by Dennis Powers, Consulting Geologist; and Rick Beauheim, SNL. The contact was straddled with 20 feet of well screen (10 feet above the contact and 10 feet below the contact) to ensure intersection with this zone. Ten feet of blank casing was installed at the bottom of the well for a sump to collect well debris and also allow a submersible pump if one was needed in the future. Final completion of the well is presented in Figures 57 and 58.

\subsection{WELL WIPP-12}

Well WIPP-12 was drilled in December 1978 in Section 17, Township 22 South, and Range 31 East (Figure 59). The borehole was drilled to a depth of 2,773.3 feet bgs and completed with 9.625 -inch casing to 1,001.5 feet bgs. In 1981 and 1982, the well was deepened through the Castile Formation to a total depth of 3,927.5 feet bgs. During deepening, a pressurized brine reservoir was encountered in the Castile Formation at a depth of 3,016 feet bgs. In 1983, the brine reservoir was sealed from the upper part of the borehole by installing a borehole plug from 2,784 to 3,000 feet bgs. The borehole plug consisted of a bridge plug covered by 27 feet of sand and 189 feet of cement. The borehole was capped until testing occurred in 1985. Following testing, a retrievable bridge plug was set in the casing below the Culebra interval. The Culebra was then perforated in 1985 from 815 to 840 feet bgs for monitoring water levels (Figure 60) (Saulnier et al., 1987).

Well WIPP-12 was used to monitor hydrostatic head in the Culebra Member of the Rustler Formation. The objective under the FY 2005 program was to plug and abandon well WIPP-12 and remove it from the monitoring network. P\&A activities at WIPP-12 occurred during July 12-16, 2005.

When brine was discovered in WIPP-12, associated hydrogen sulfide gas $\left(\mathrm{H}_{2} \mathrm{~S}\right)$ was also reported to be present. Because of the potential for $\mathrm{H}_{2} \mathrm{~S}$ gas buildup between the lower plug and the upper packer over the decade, extra precautionary measures were undertaken prior to and during the well plugging activities to protect workers. 


\section{Basic Data Report for Well Plugging and Abandonment and Reconfiguration Activities for Fiscal Year 2005 \\ DOE/WIPP 05-3326}

Prior to commencing work at WIPP-12, the comprehensive "Site Safety \& Hydrogen Sulfide $\left(\mathrm{H}_{2} \mathrm{~S}\right)$ Work Plan: WIPP Process, Public and Worksite Protection Guide" was developed. The guide contained specific emergency response planning and implementation, safety planning and implementation, rescue and first aid, contingency planning, and emergency communication planning for the job. Also, the plan contained specific work scope to follow for a safe operation.

In accordance with the plan, the area was first equipped with proper $\mathrm{H}_{2} \mathrm{~S}$ hazard signage, wind socks, and a hazmat/rescue trailer that was manned 24 hours a day. Because there was a potential for $\mathrm{H}_{2} \mathrm{~S}$ gas at this location and possible blowout at the well head, the plan called for preliminary actions for the well itself before the actual P\&A. The well was filled with 11 pound brine water to decrease the potential for fire hazards. A cellar measuring 6 feet $\times 6$ feet $\times 4$ feet deep was excavated around the well head. The excavation was then braced with shoring. The well casing was then cut off 5 feet bgs to allow the blowout preventer (BOP) to be installed. A flange was welded to the casing, then the BOP was securely bolted to the well head so that if there was a release of $\mathrm{H}_{2} \mathrm{~S}$ gas it could be shut into the well. The BOP was tested for leaks and proper operation. The drill rig and well were then set up with audible and visual $\mathrm{H}_{2} \mathrm{~S}$ gas monitors (Photos 26, 27, and 28).

Following the installation of the BOP, the well was scraped to the depth of the packer (984 feet bgs) as described in Section 2.0. This was followed by circulating the well of debris until clean return was confirmed. After circulating the well, the packer was removed as described in Section 2.0. A kill truck was attached to the BOP in the event an uncontrollable $\mathrm{H}_{2} \mathrm{~S}$ release occurred when the packer was removed. The kill truck would allow heavy brine to be pressure pumped into the well forcing the $\mathrm{H}_{2} \mathrm{~S}$ gas back into the formation, allowing the BOP to be shut-in and prevent a gas release until proper flare equipment could be set up. Additionally, all personnel working around the rig and within the exclusion zone were required to wear supplied air respirators until the packer was removed from the well. The packer was removed without incident and no $\mathrm{H}_{2} \mathrm{~S}$ gas or brine was encountered. However, when the packer was released, there was enough pressure buildup beneath it to force the assembly up approximately three feet in the well (Photos 29 and 30).

Following removal of the packer, the crew removed the supplied air respirators and work continued under Level D PPE conditions (hard hats, steel toe boots, gloves, safety glasses) with continuous monitoring and escape packs. Following the packer removal, the remaining casing was scraped and circulated in preparation for cement. The well was then circulated to total depth followed by cementing using tremmie pipe as described in Section 2.0. A total of 1,188 cubic feet of Class C Neat cement slurry was used to plug the well to the surface. Upon completion of cementing, a well monument was fixed to the well location in accordance to BLM requirements (Figure 61) (Photos 31 and 32). 


\section{Basic Data Report for Well Plugging and Abandonment and Reconfiguration Activities for Fiscal Year 2005

Figure 57

Construction of Well $\mathrm{H}-3 \mathrm{~d}$

After Reconfiguration (Large Scale)

(Not to Scale)

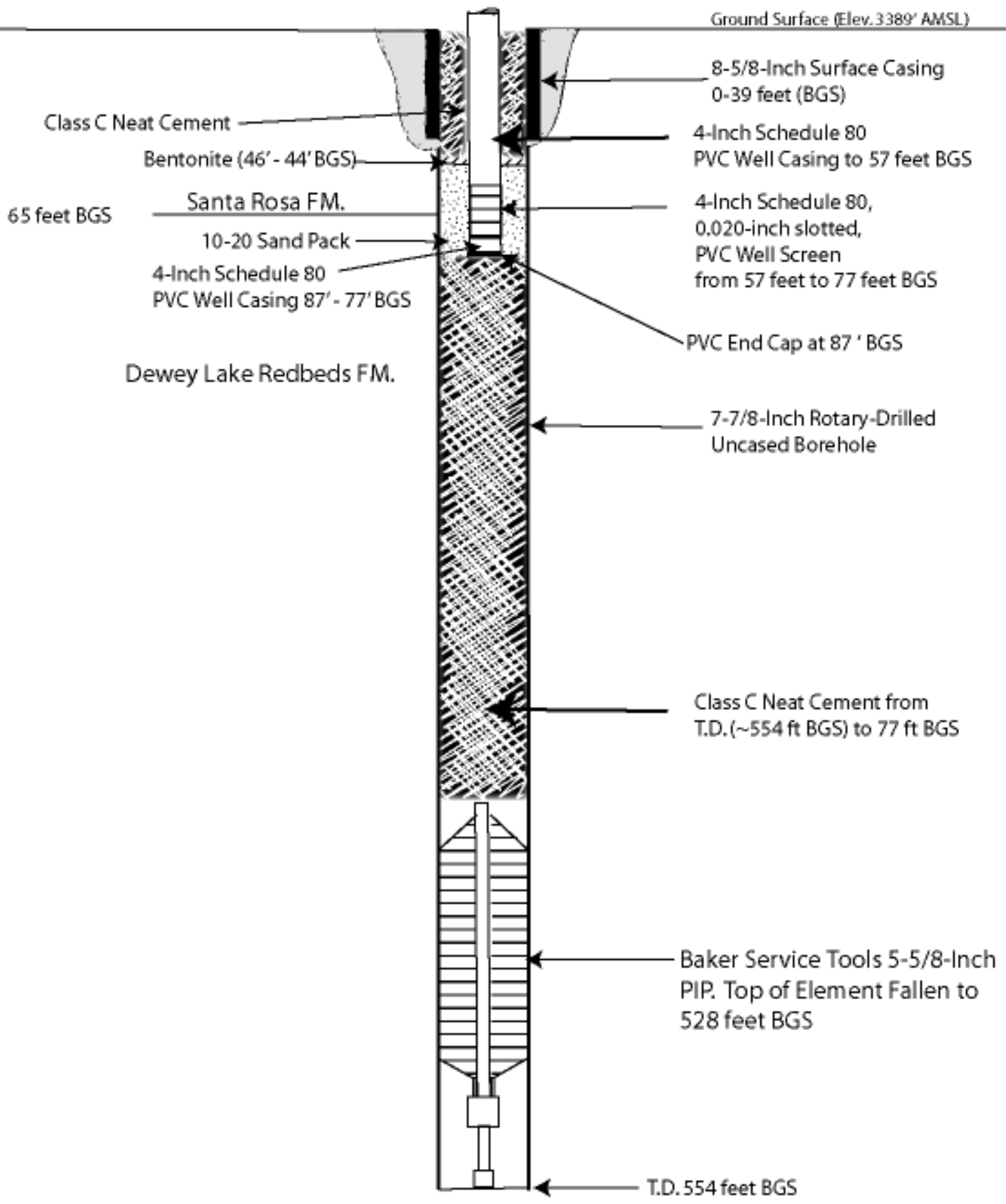




\section{Basic Data Report for Well Plugging and Abandonment and Reconfiguration Activities for Fiscal Year 2005

Figure 58

Construction of Well $\mathrm{H}-3 \mathrm{~d}$

After Reconfiguration (Detail)

(Not to Scale)

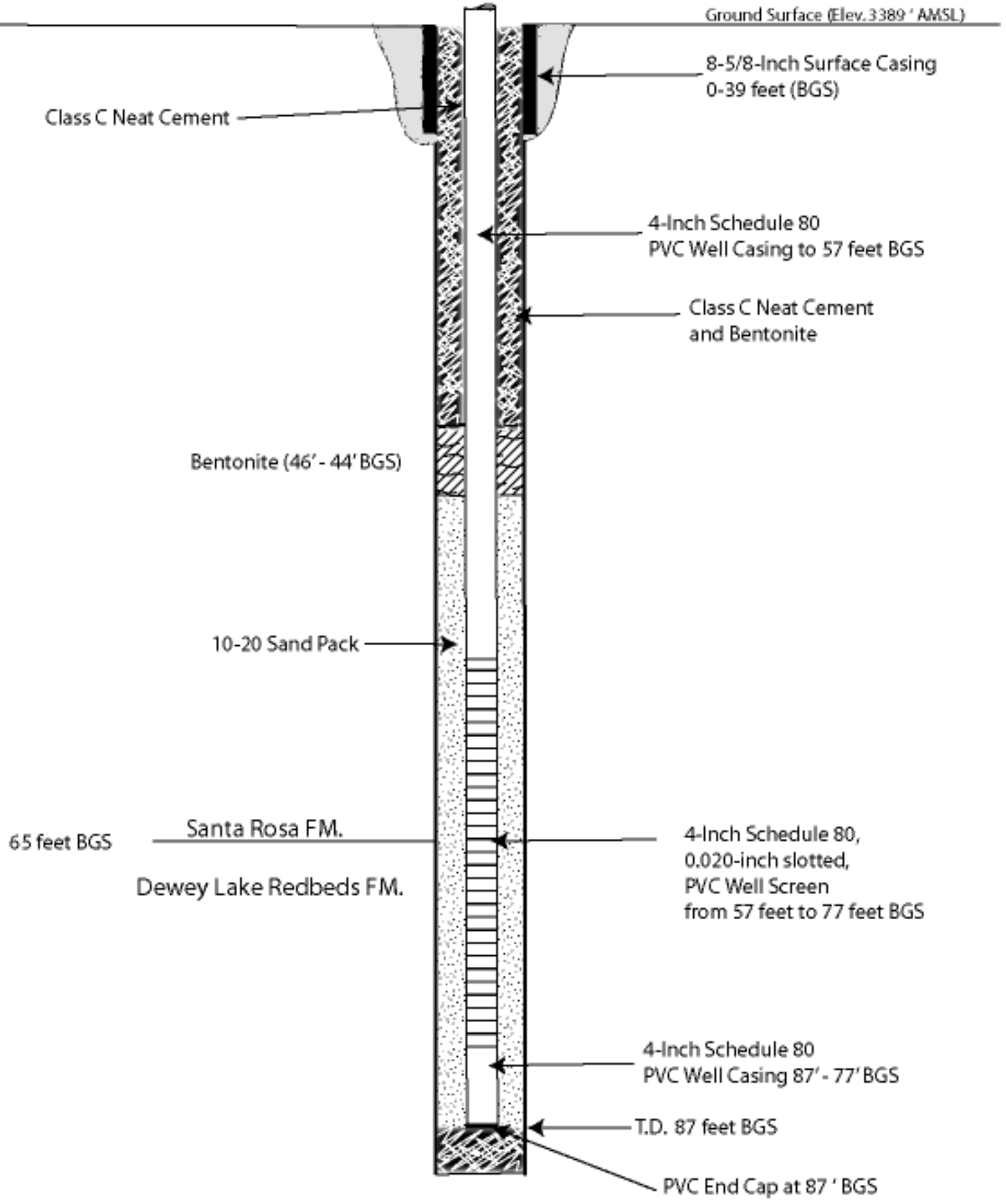


Basic Data Report for Well Plugging and Abandonment and Reconfiguration Activities for Fiscal Year 2005

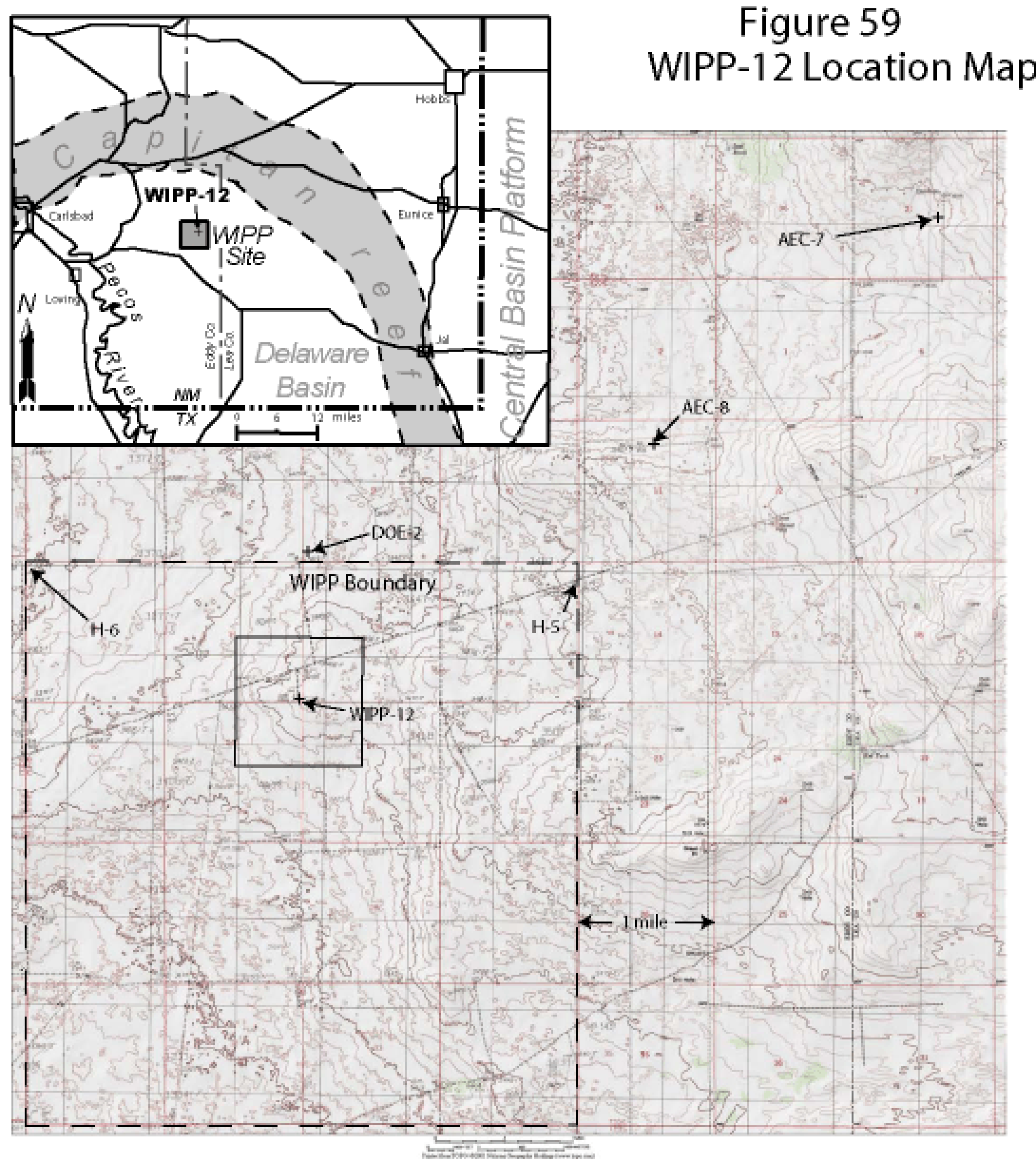




\section{Basic Data Report for Well Plugging and Abandonment and Reconfiguration Activities for Fiscal Year 2005

Figure 60

Construction of WIPP-12

Before P\&A

(Not to Scale)

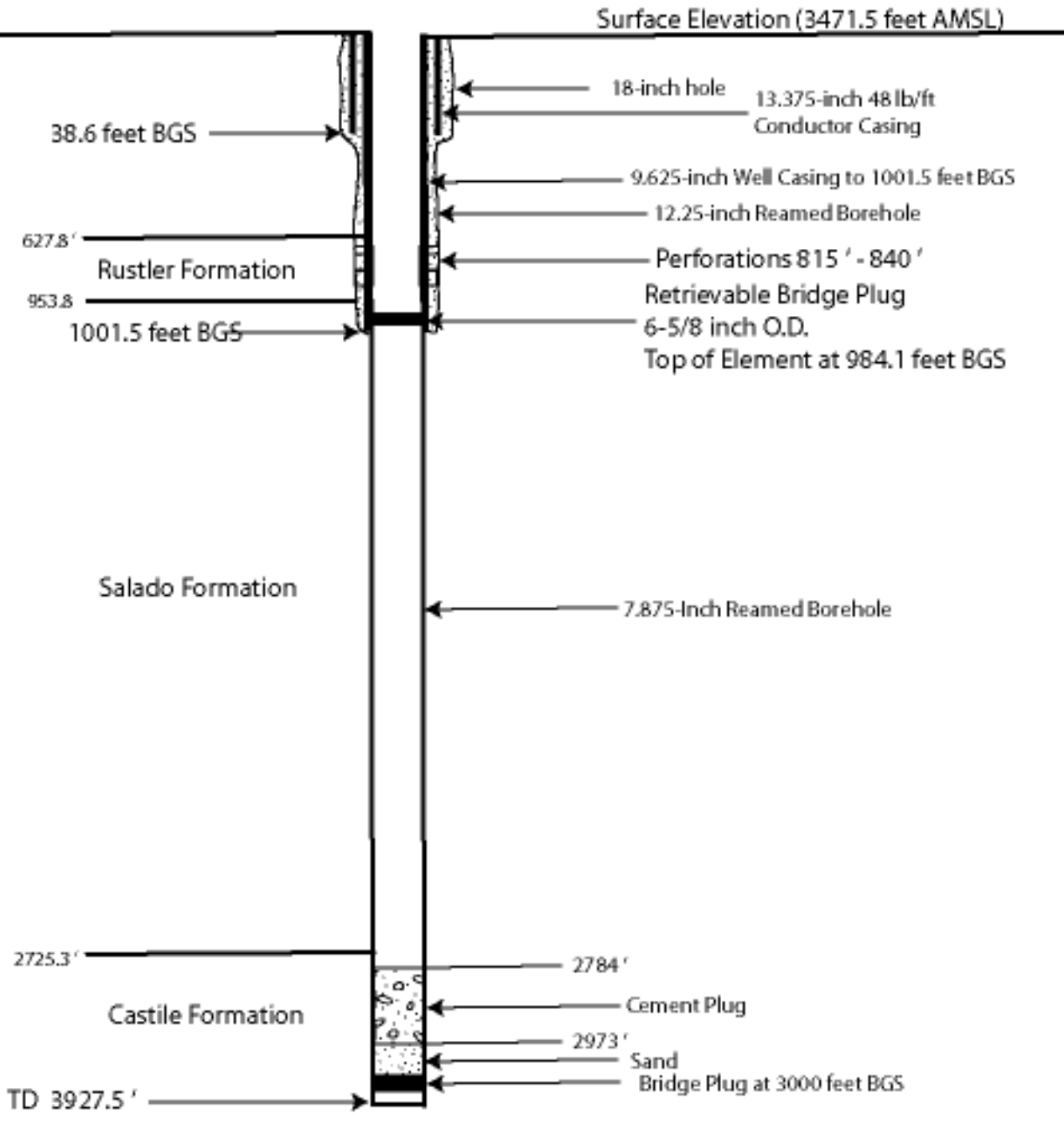




\section{Basic Data Report for Well Plugging and Abandonment and Reconfiguration Activities for Fiscal Year 2005

Figure 61

Construction of WIPP-12

After P\&A

(Not to Scale)

$6^{\prime} \times 6^{\prime} \times 4^{\prime}$ Reinforced Cellar

38.6 feet BGS
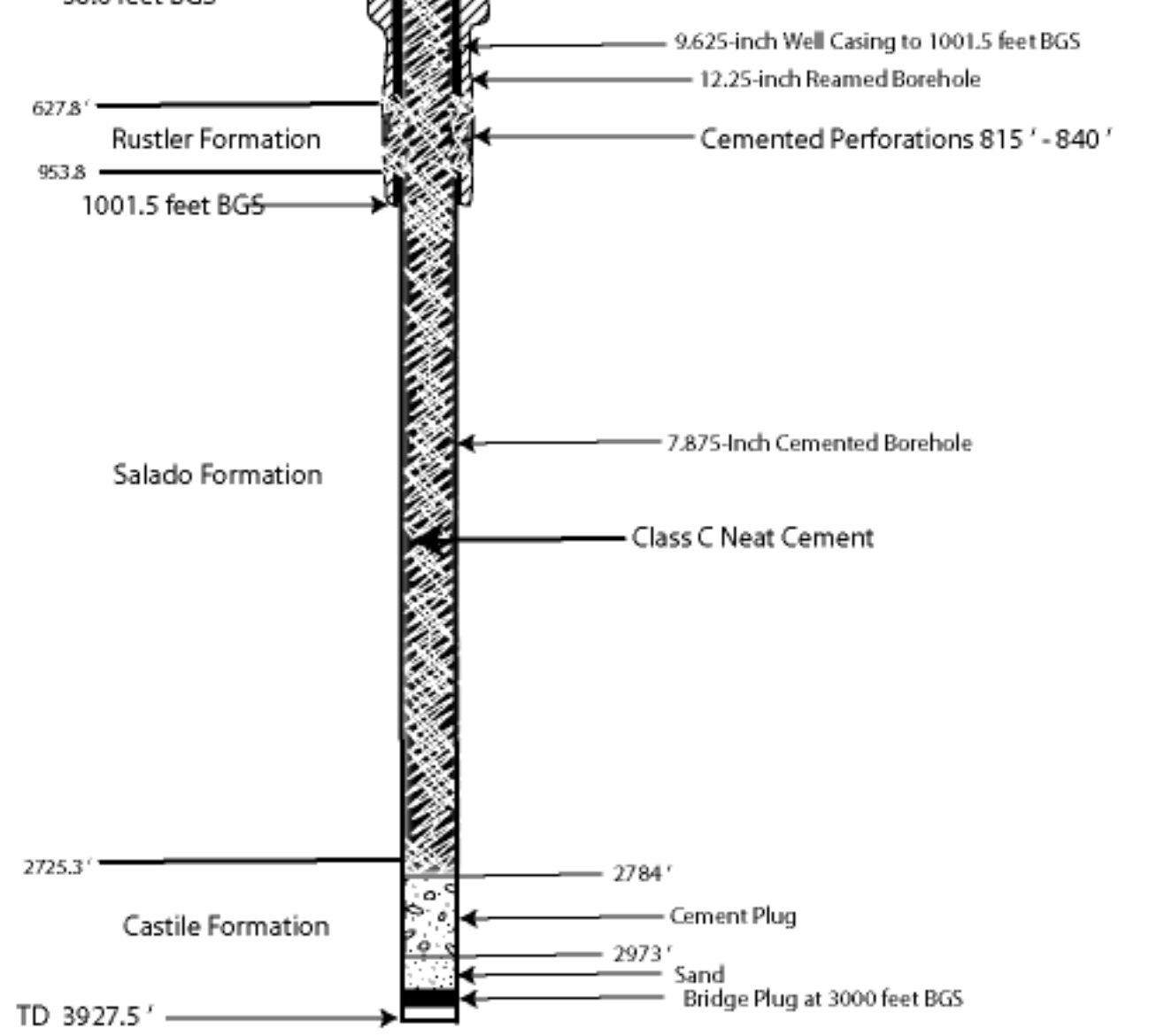


\section{Basic Data Report for Well Plugging and Abandonment and Reconfiguration Activities for Fiscal Year 2005 \\ DOE/WIPP 05-3326}

\section{REFERENCES}

Beauheim, R. L., and G. J. Ruskauff, 1998. Analysis of Hydraulic Tests of the Culebra and Magenta Dolomites and Dewy Lake Redbeds Conducted at the Waste Isolation Pilot Plant Site. SAND98-0049. Albuquerque, NM. Sandia National Laboratories.

Hydro Geo Chem, Inc., 1985. WIPP Hydrology Program, Waste Isolation Pilot Plant, SENM, Hydrologic Data Report \#1. SAND85-7206. Albuquerque, NM. Sandia National Laboratories.

Mercer, J. W. 1990. Basic Data Report for Drillholes at the H-11 Complex (Waste Isolation Pilot Plant - WIPP). SAND89-0200.

Saulnier, G. J. Jr., G. A. Freeze, and W. A. Stensrud, 1987. WIPP Hydrology Program, Waste Isolation Pilot Plant, Southeastern New Mexico, Hydrologic Data Report \#4. SAND86-7166. Albuquerque, NM. Sandia National Laboratories.

Sandia National Laboratories and United States Geological Survey 1979. Basic Data Report for Drillhole WIPP-29 (Waste Isolation Pilot Plant-WIPP). SAND79-0283. Albuquerque, NM. Sandia National Laboratories.

Sandia National Laboratories and D'Appolonia Consulting Engineers 1983. Basic Data Report fo Drillhole AEC-8, Waste Isolation Pilot Plant - WIPP. SAND79-0269. Albuquerque, NM. Sandia National Laboratories.

Sandia National Laboratories and Intera Technologies, Inc. 1986. WIPP Hydrology Program Waste Isolation Pilot Plant, Southeastern New Mexico, Hydrologic Data Report \#3. SAND86-7109. Albuquerque, NM. Sandia National Laboratories.

Stensrud, W. A., M. A. Bame, K. D. Lantz, J. B. Palmer, and G. J. Saulnier, Jr. 1987. WIPP Hydrology Program, Waste Isolation Pilot Plant, Southeastern New Mexico, Hydrologic Data Report \#5. SAND87-7125. Albuquerque, NM. Sandia National Laboratories.

Stensrud, W. A., M. A. Bame, K. D. Lantz, T. L. Cauffman, J. B. Palmer, and G. J. Saulnier, Jr. 1988a. WIPP Hydrology Program, Waste Isolation Pilot Plant, Southeastern New Mexico, Hydrologic Data Report \#6. SAND87-7166. Albuquerque, NM. Sandia National Laboratories.

Stensrud, W. A., M. A. Bame, K. D. Lantz, J. B. Palmer, and G. J. Saulnier, Jr. 1988 b. WIPP Hydrology Program, Waste Isolation Pilot Plant, Southeastern New Mexico, Hydrologic Data Report \#7. SAND88-7014. Albuquerque, NM. Sandia National Laboratories. 


\section{Basic Data Report for Well Plugging and Abandonment and Reconfiguration Activities for Fiscal Year 2005

Stensrud, W. A., M. A. Bame, K. D. Lantz, J. B. Palmer, and G. J. Saulnier, Jr. 1990. WIPP Hydrology Program, Waste Isolation Pilot Plant, Southeastern New Mexico, Hydrologic Data Report \#8. SAND89-7056. Albuquerque, NM. Sandia National Laboratories. 
Basic Data Report for Well Plugging and Abandonment and Reconfiguration Activities for Fiscal Year 2005

DOE/WIPP 05-3326

\section{APPENDIX A}

PHOTOGRAPHS 
Basic Data Report for Well Plugging and Abandonment and Reconfiguration Activities for Fiscal Year 2005

DOE/WIPP 05-3326

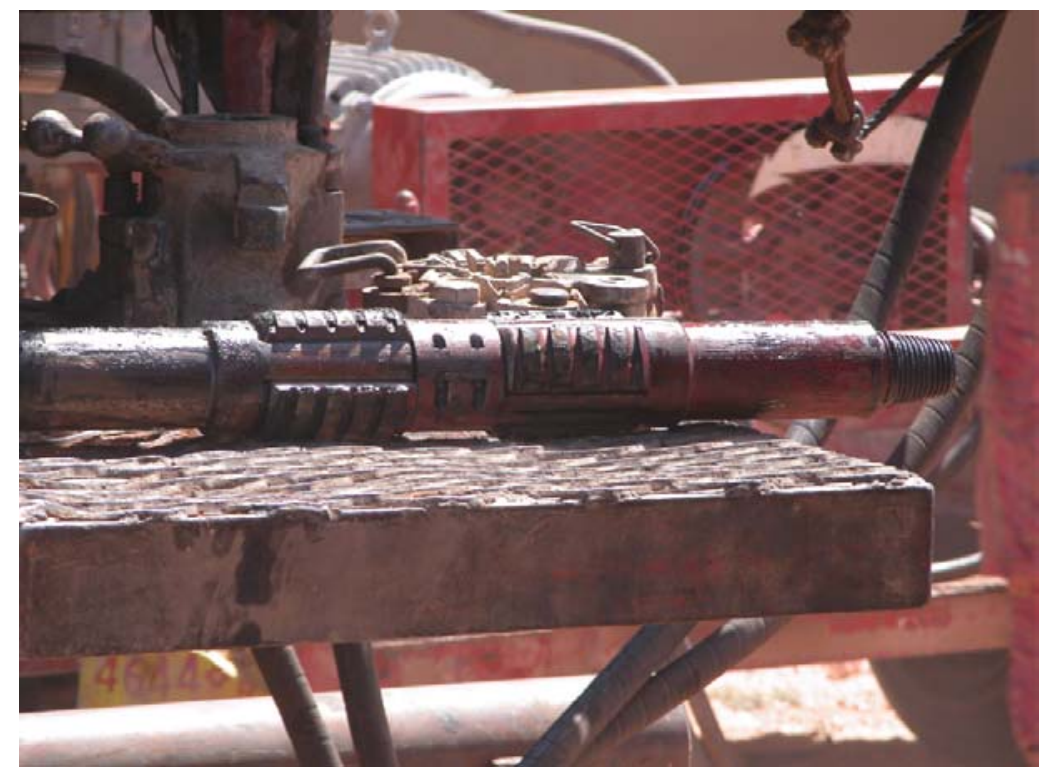

Photo 1 - Casing Scraper

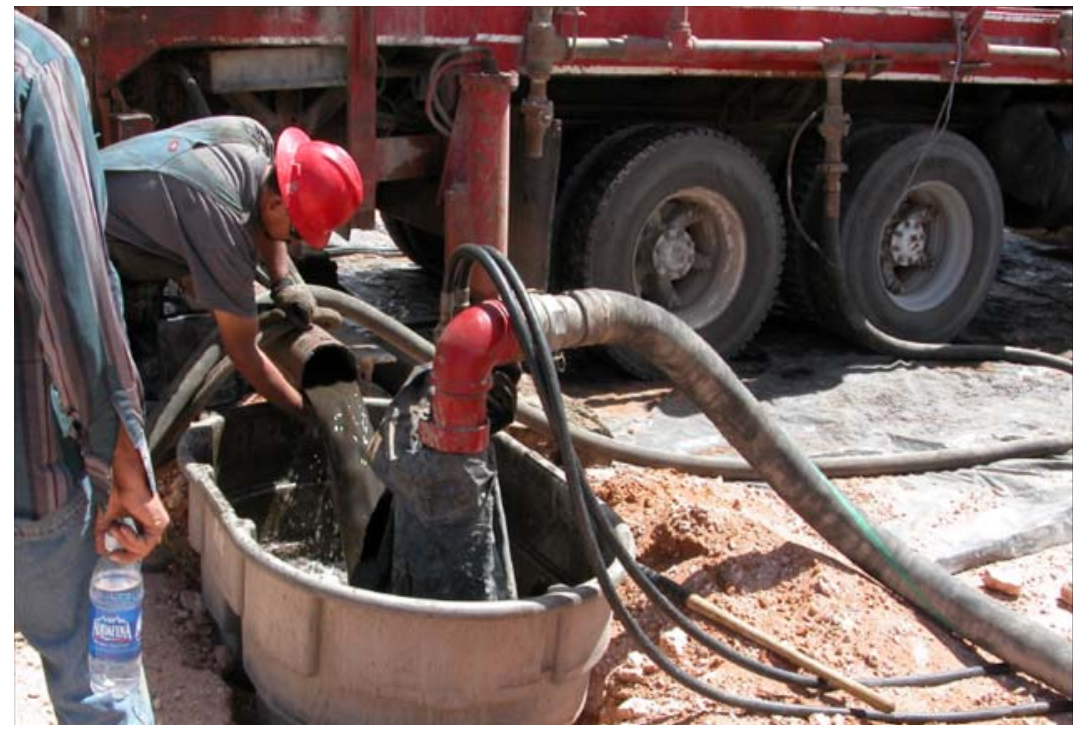

Photo 2 - Collection Tub 
Basic Data Report for Well Plugging and Abandonment and Reconfiguration Activities for Fiscal Year 2005

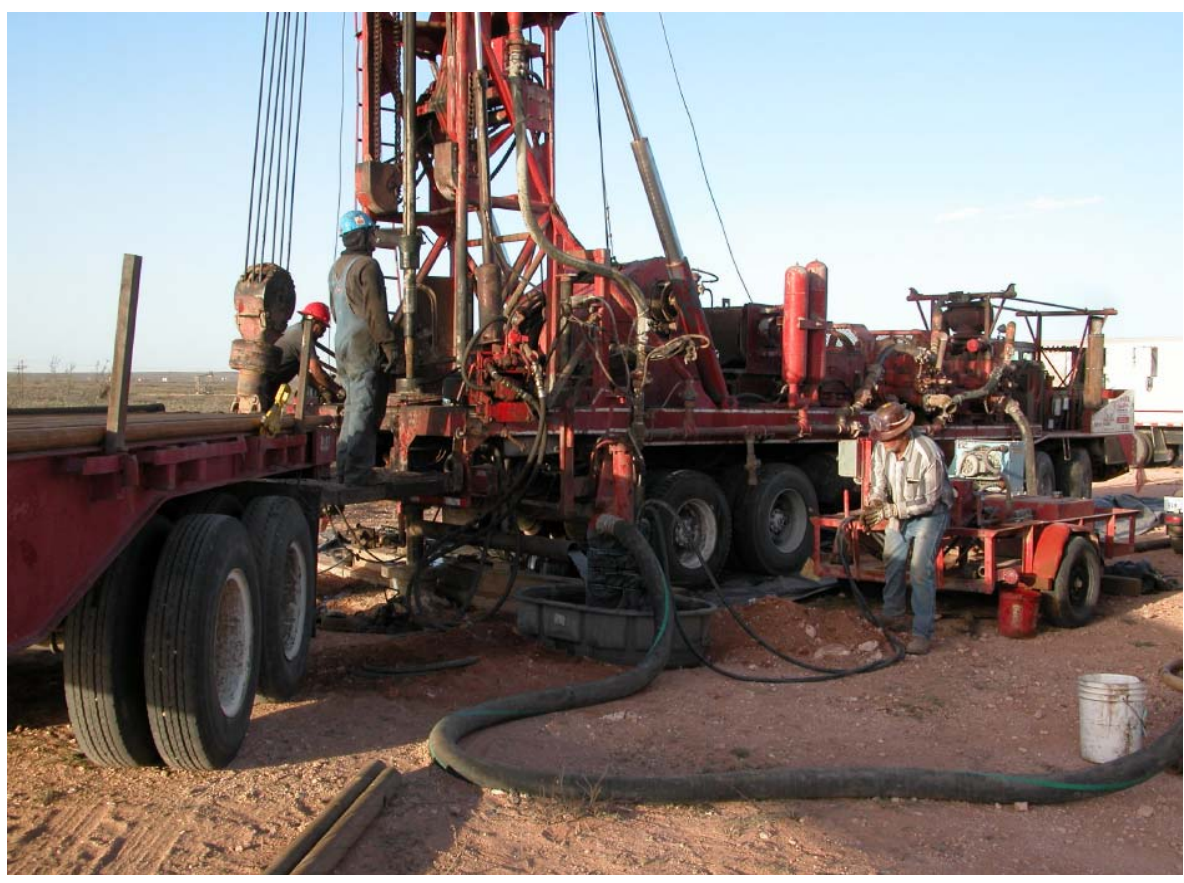

Photo 3 - Tremmie Pipe Cement Emplacement

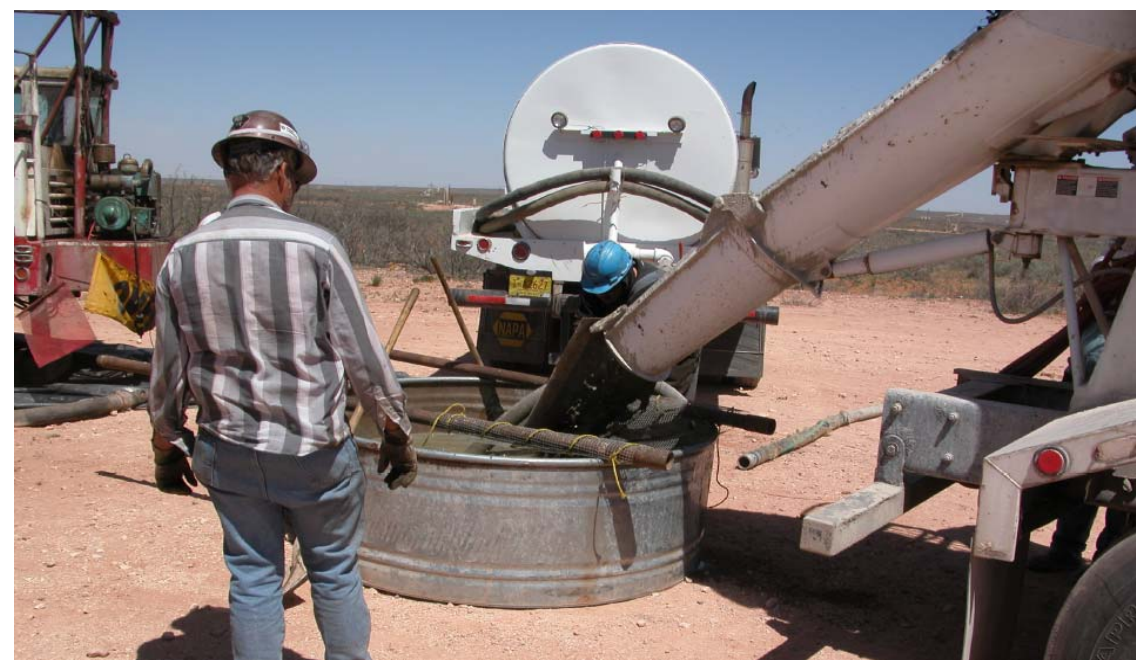

Photo 4 - Cement Truck Pouring Into a Tub 
Basic Data Report for Well Plugging and Abandonment and Reconfiguration Activities for Fiscal Year 2005

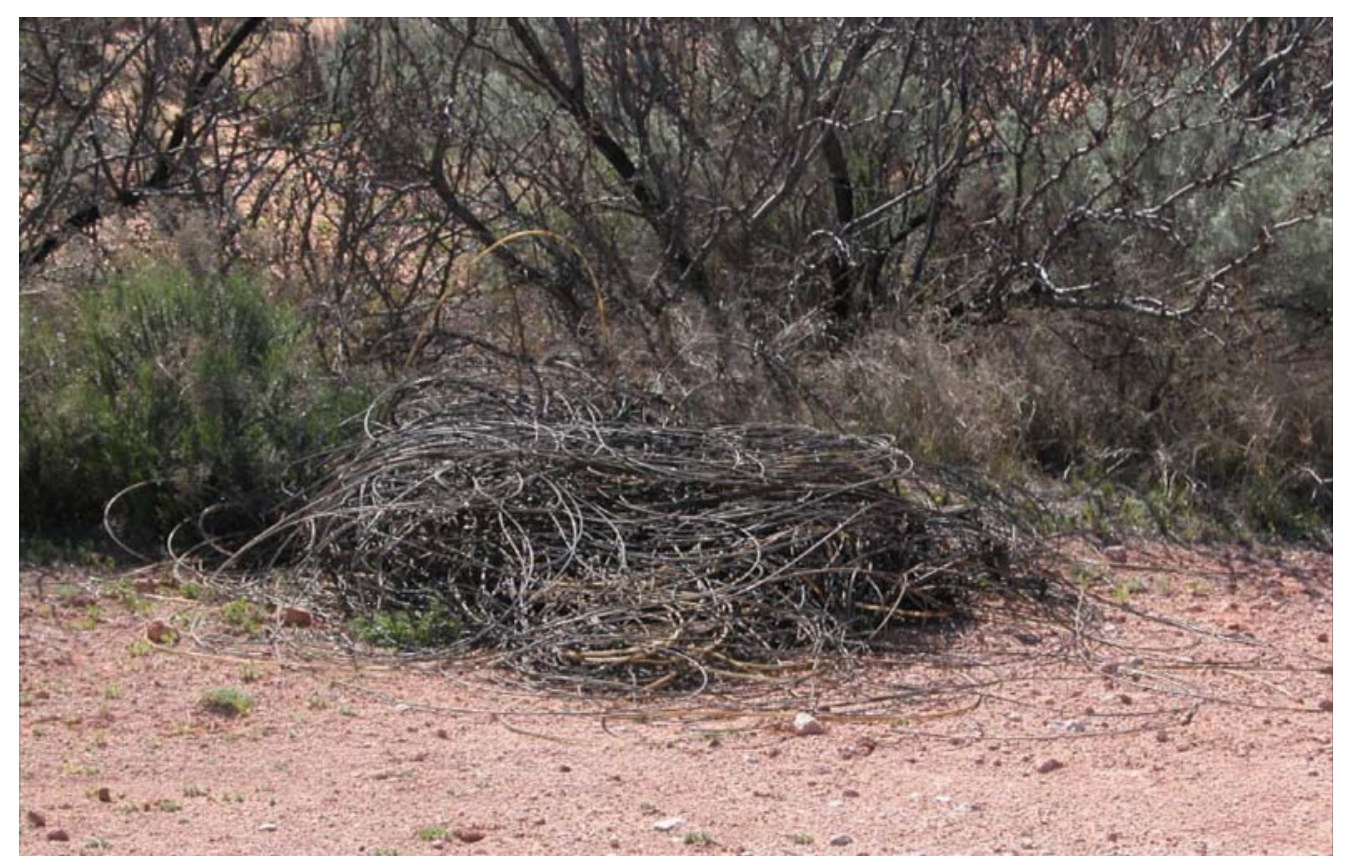

Photo 5 - Transducer Cable From Well AEC-8

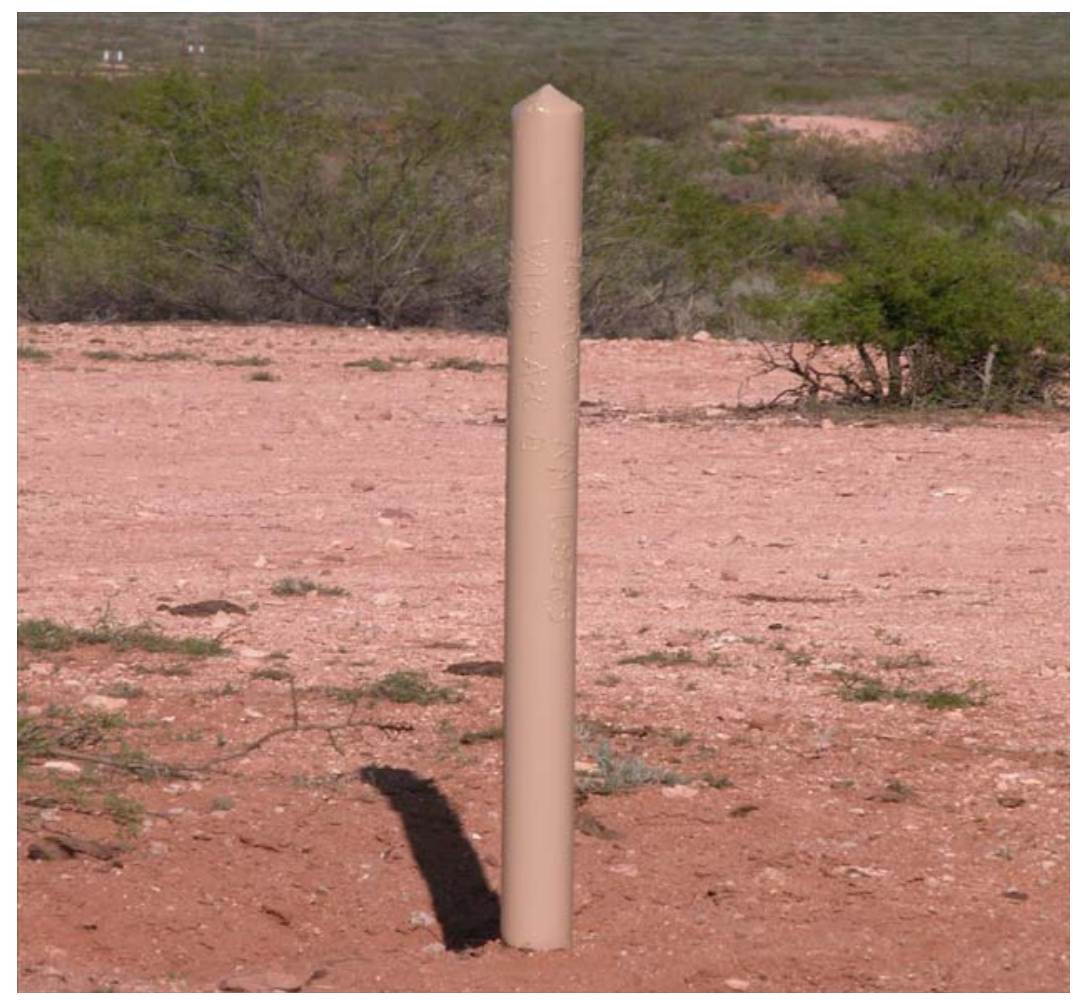

Photo 6 - Well Monument at AEC-8 
Basic Data Report for Well Plugging and Abandonment and Reconfiguration Activities for Fiscal Year 2005

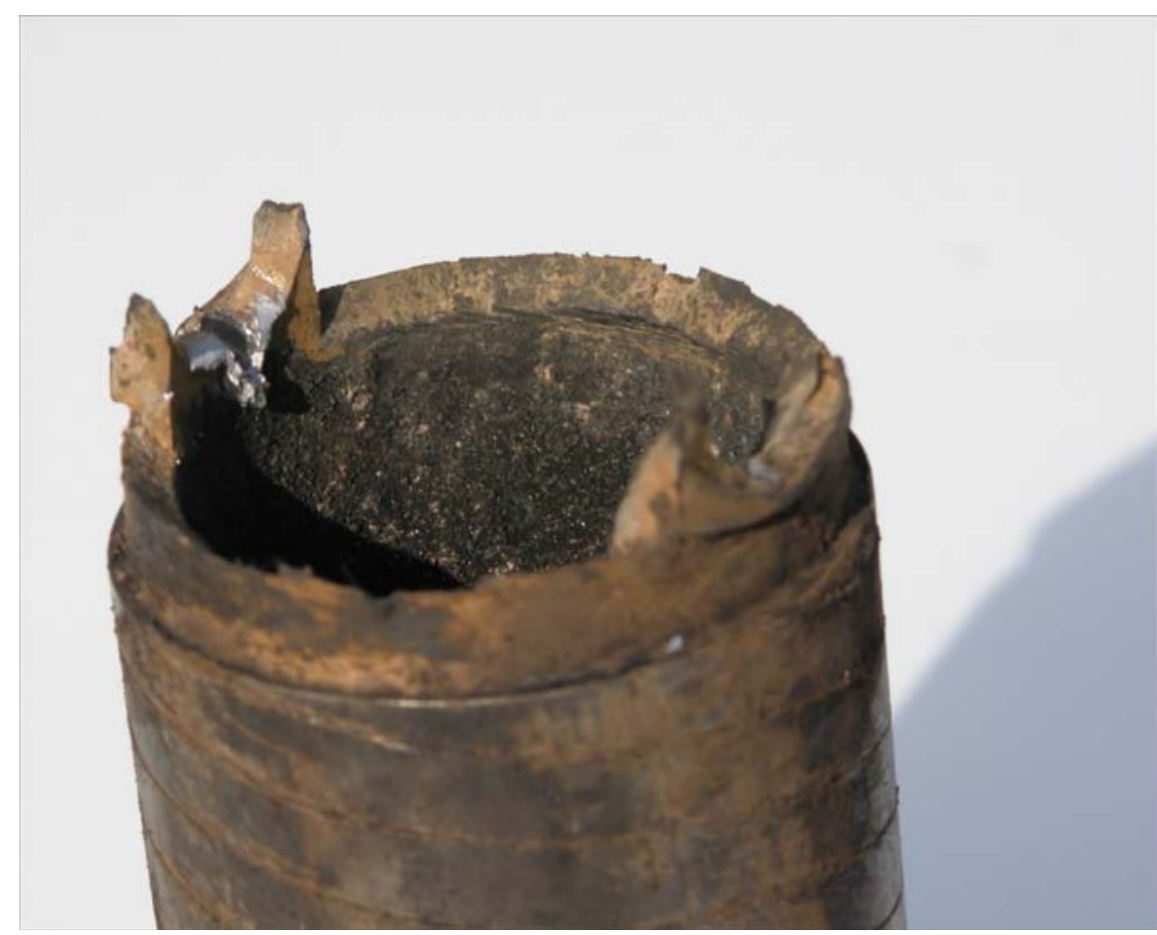

Photo 7 - Top of Packer Mandrel Separated at Lugs at H-2b1

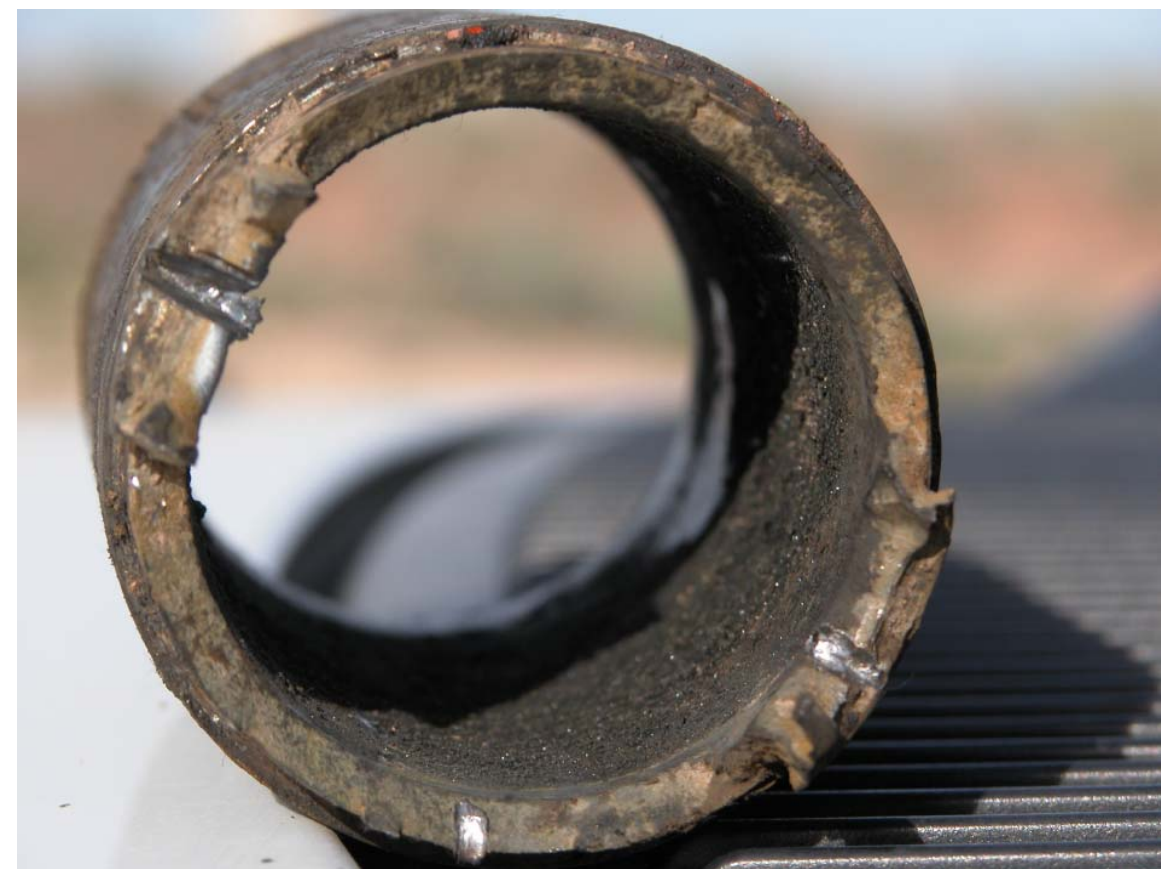

Photo 8 - Separated Mandrel at Lugs at H-2b1 
Basic Data Report for Well Plugging and Abandonment and Reconfiguration Activities for Fiscal Year 2005

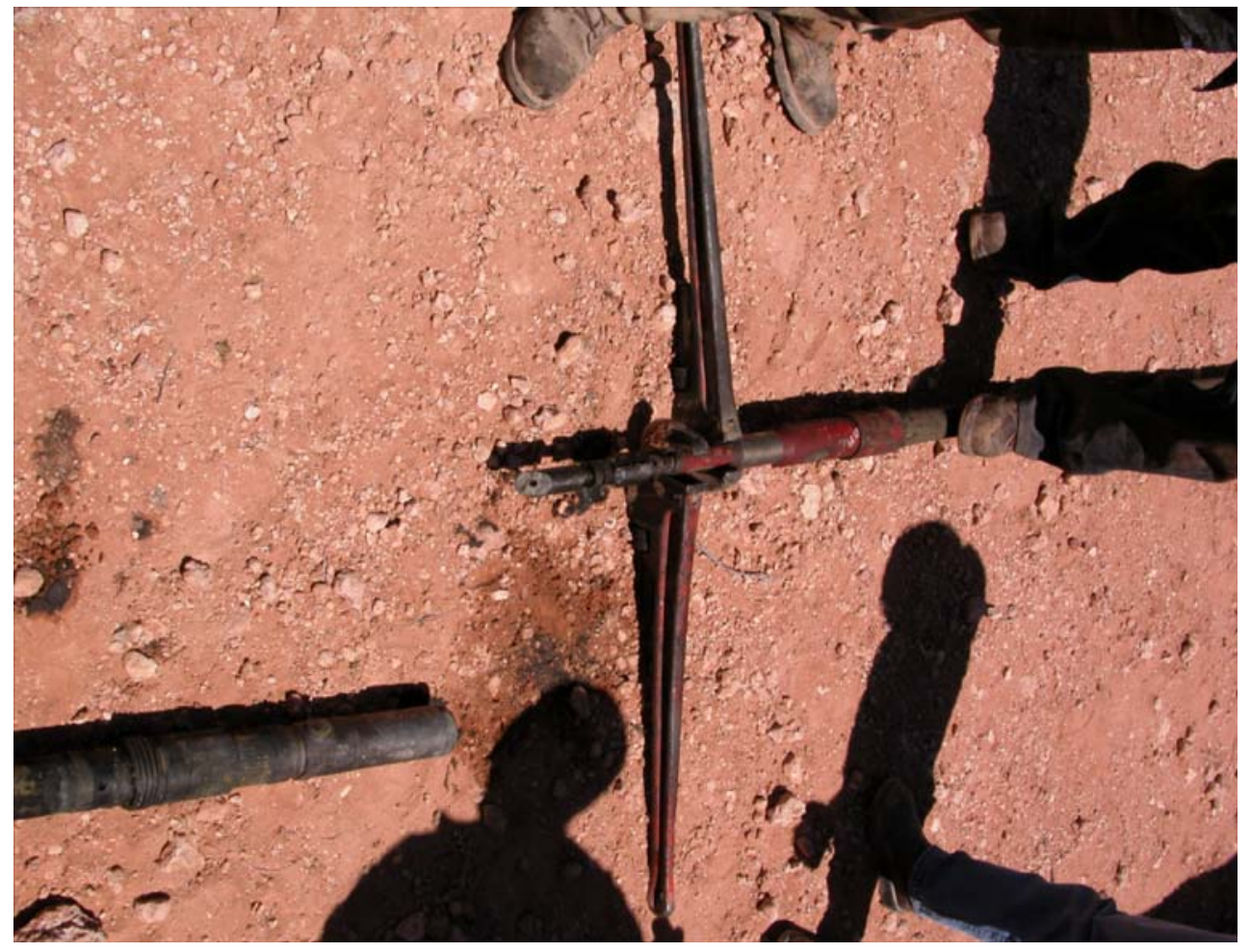

Photo 9 - Spear Removal From Packer at $\mathrm{H}-14$

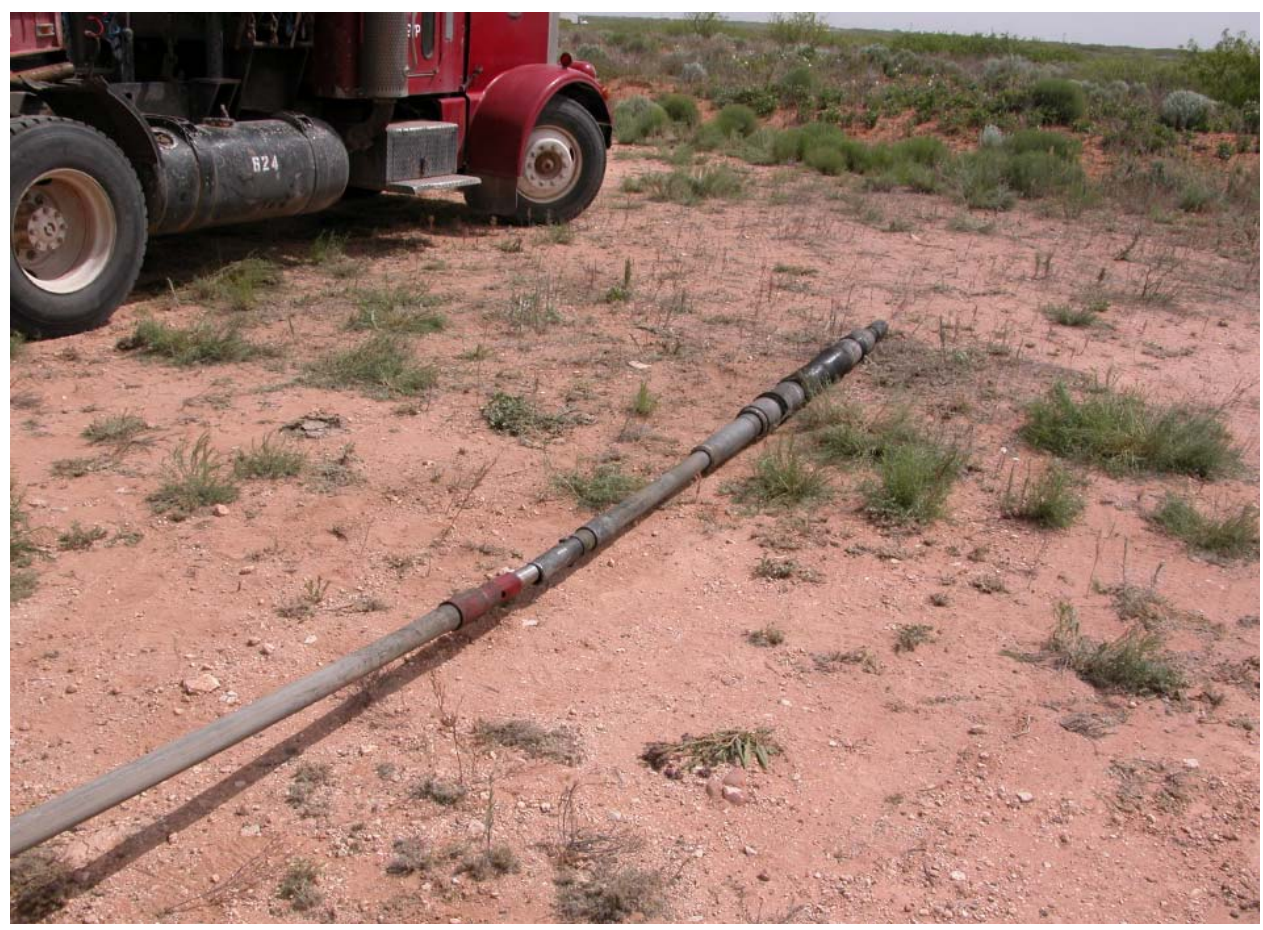

Photo 10 - Spear and Packer at Well H-18 


\section{Basic Data Report for Well Plugging and Abandonment and}

Reconfiguration Activities for Fiscal Year 2005

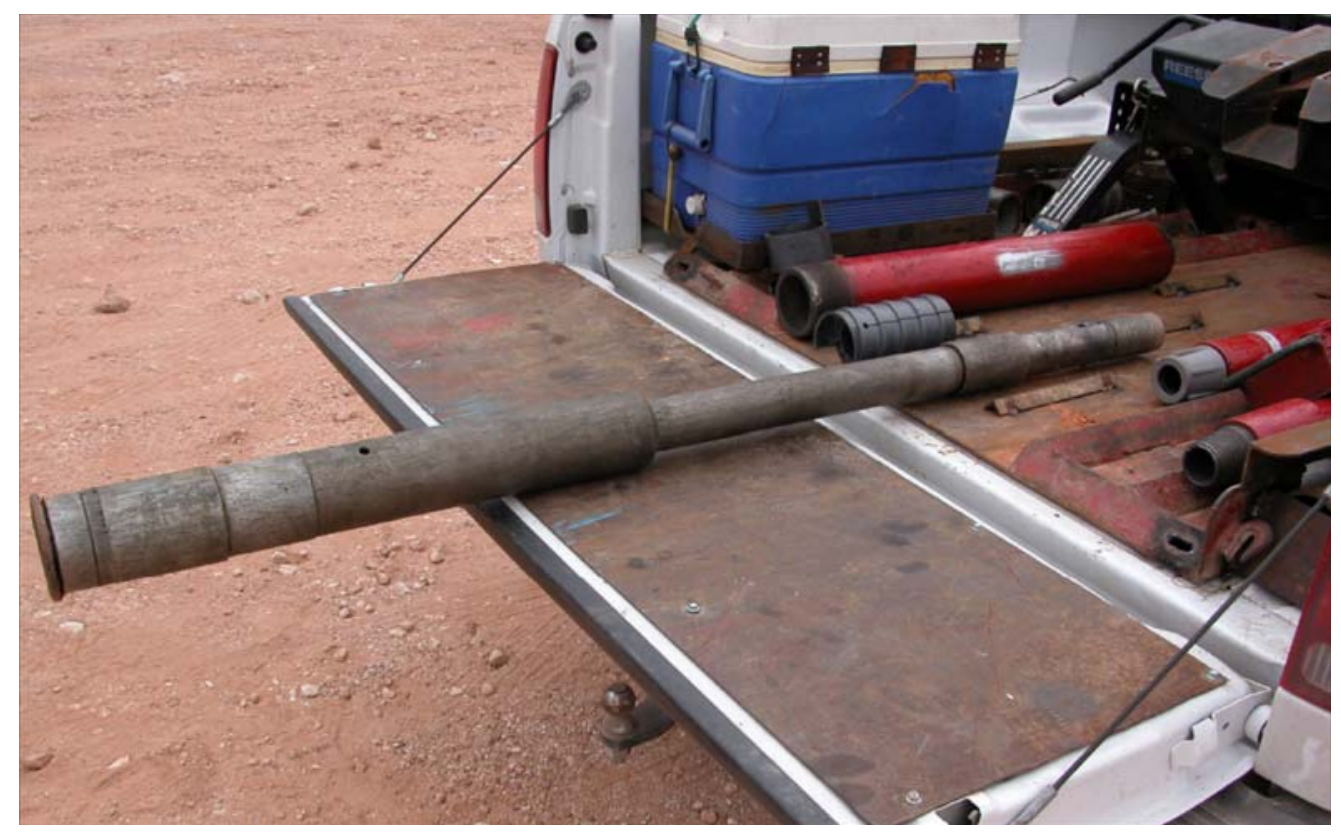

Photo 11 - Upper Mandrel Separated at Packer Element - Well H-4c

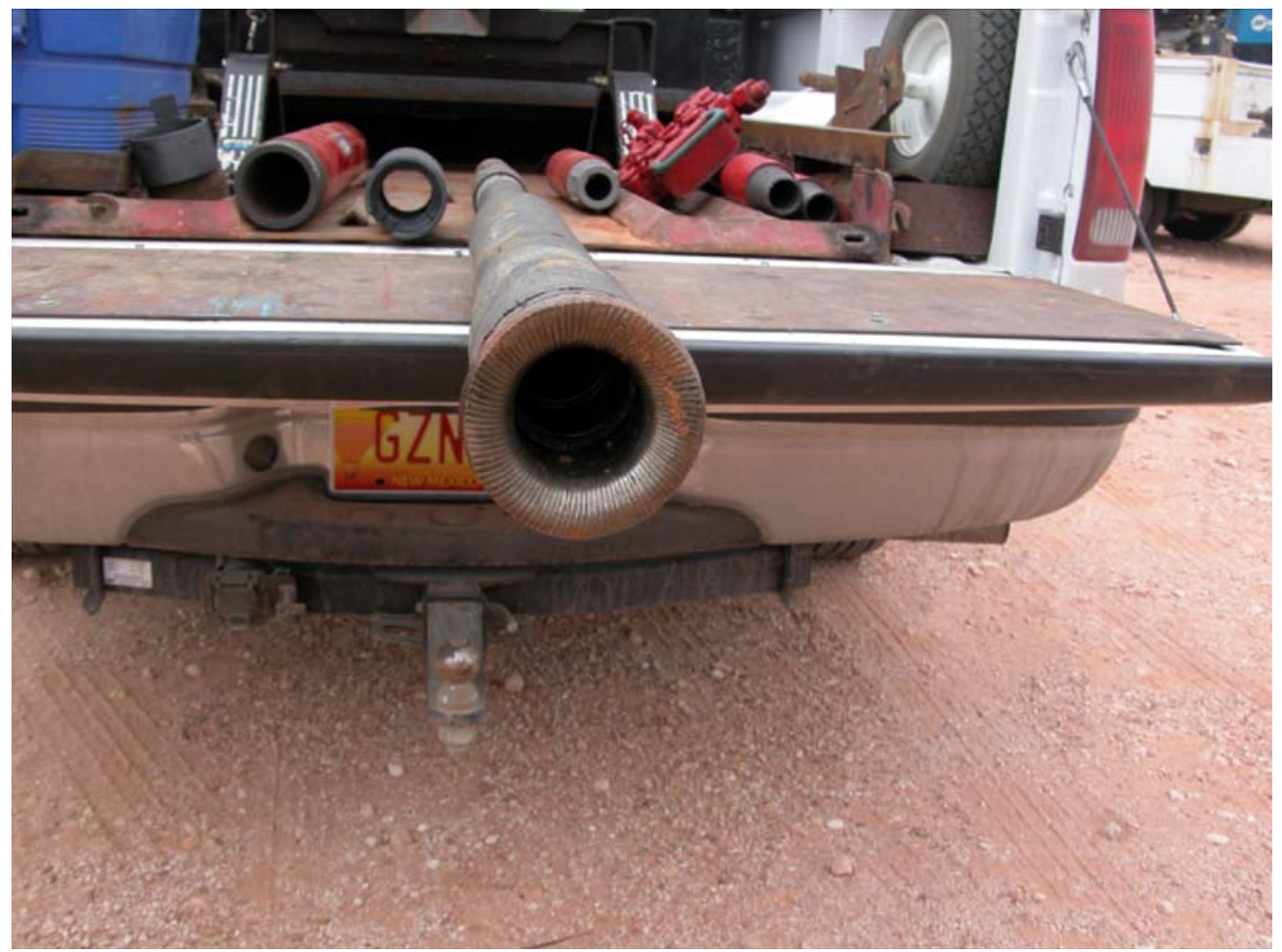

Photo 12 - Top of Separated Packer Element at Well H-4c 


\section{Basic Data Report for Well Plugging and Abandonment and Reconfiguration Activities for Fiscal Year 2005 DOE/WIPP 05-3326}

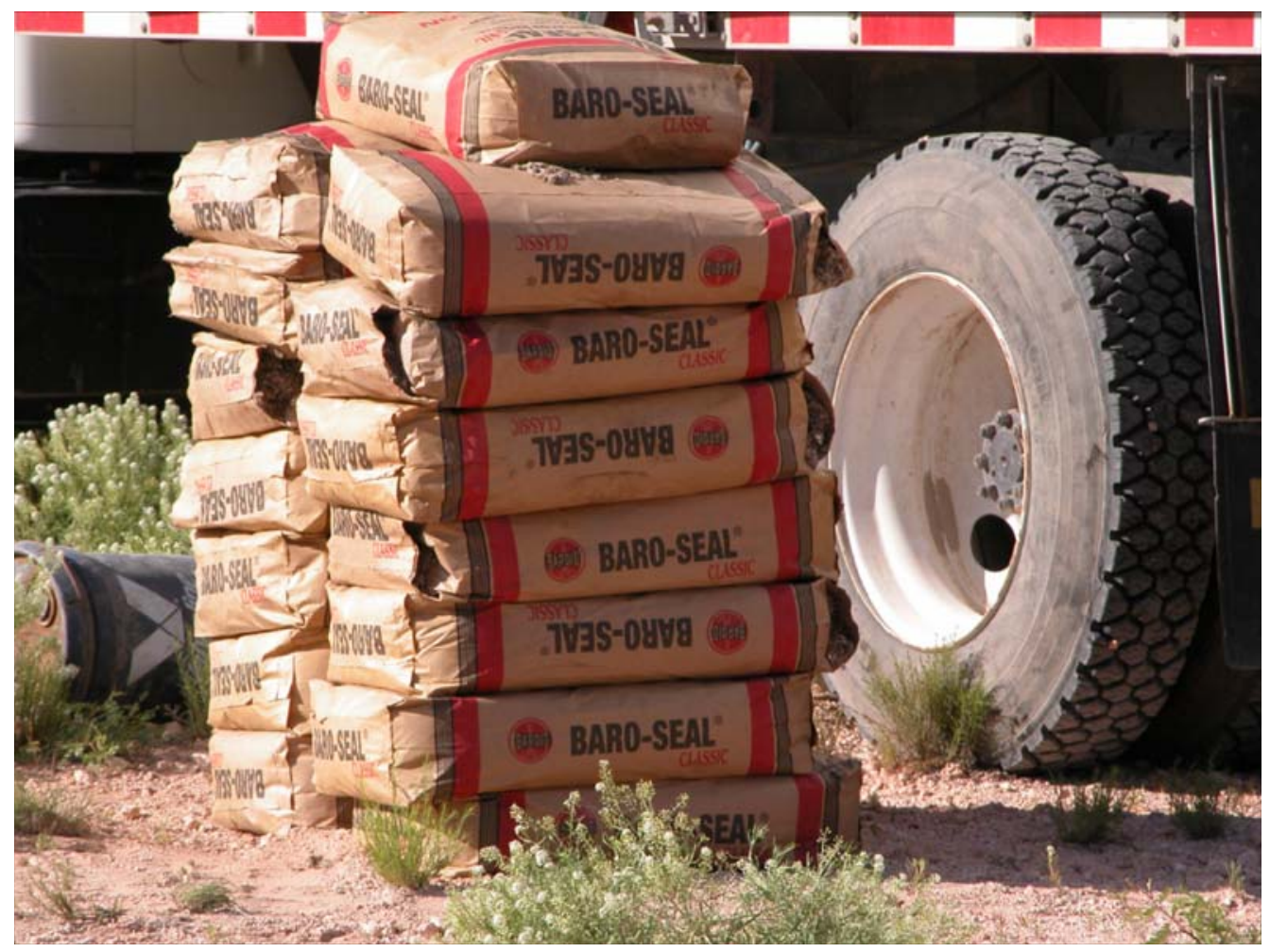

Photo 13 - Baro-Seal ${ }^{\mathrm{TM}}$ Used at Well H-7c

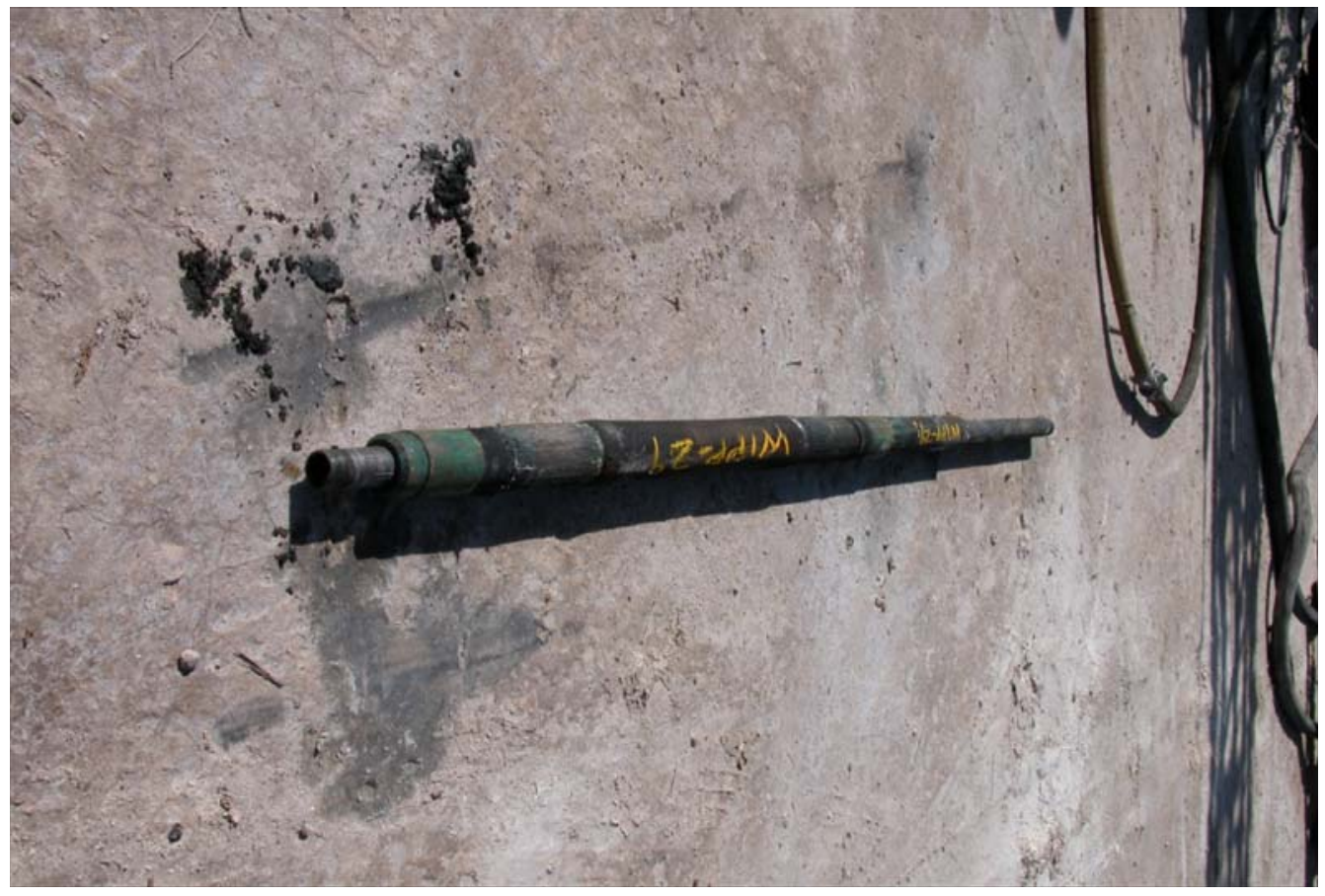

Photo 14 - Packer Removed From Well WIPP-29 
Basic Data Report for Well Plugging and Abandonment and Reconfiguration Activities for Fiscal Year 2005

DOE/WIPP 05-3326

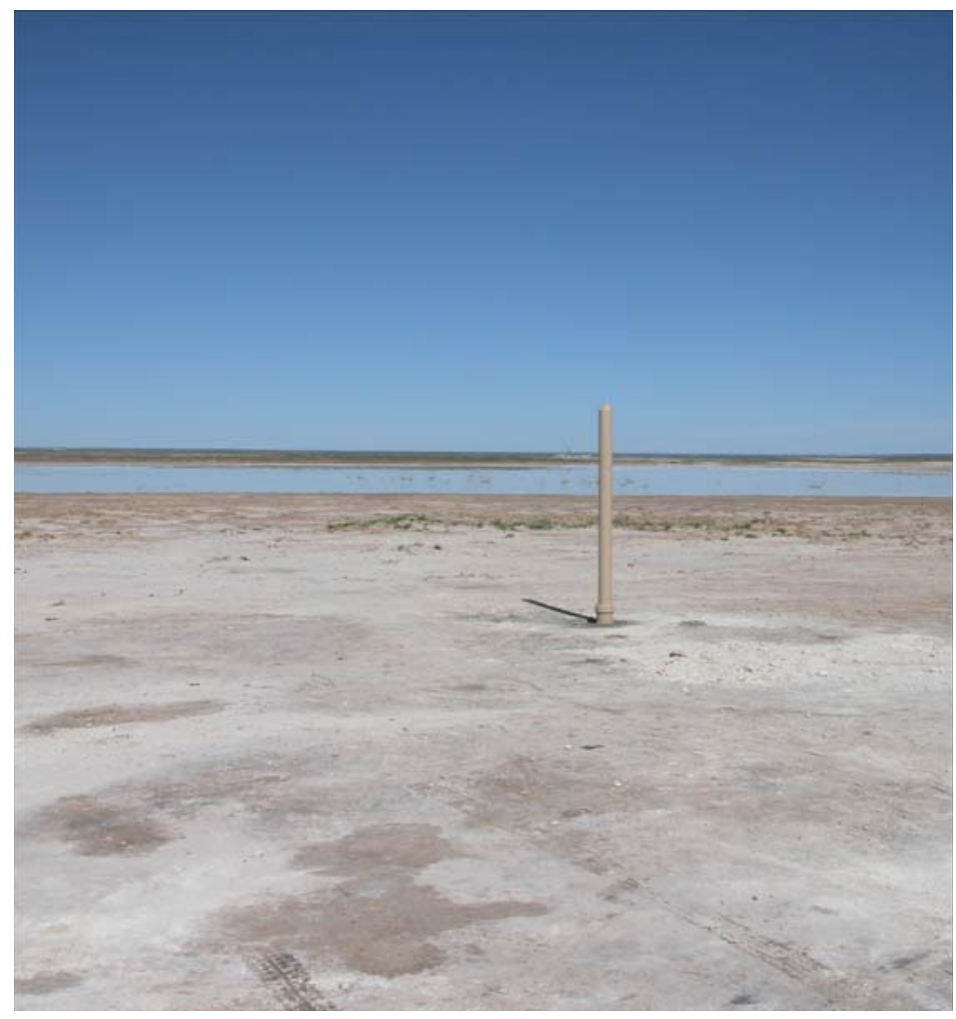

Photo 15 - Monument at WIPP-29

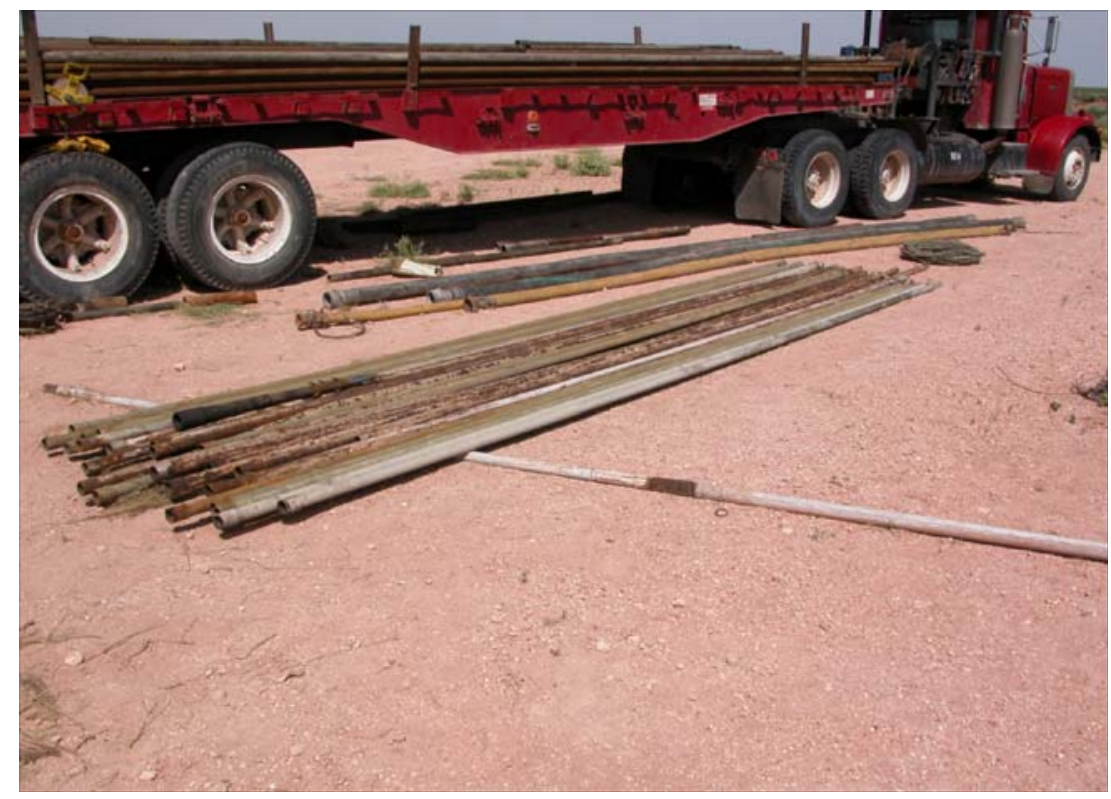

Photo 16 - Galvanized Tubing at H-6a 


\section{Basic Data Report for Well Plugging and Abandonment and Reconfiguration Activities for Fiscal Year 2005 DOE/WIPP 05-3326}

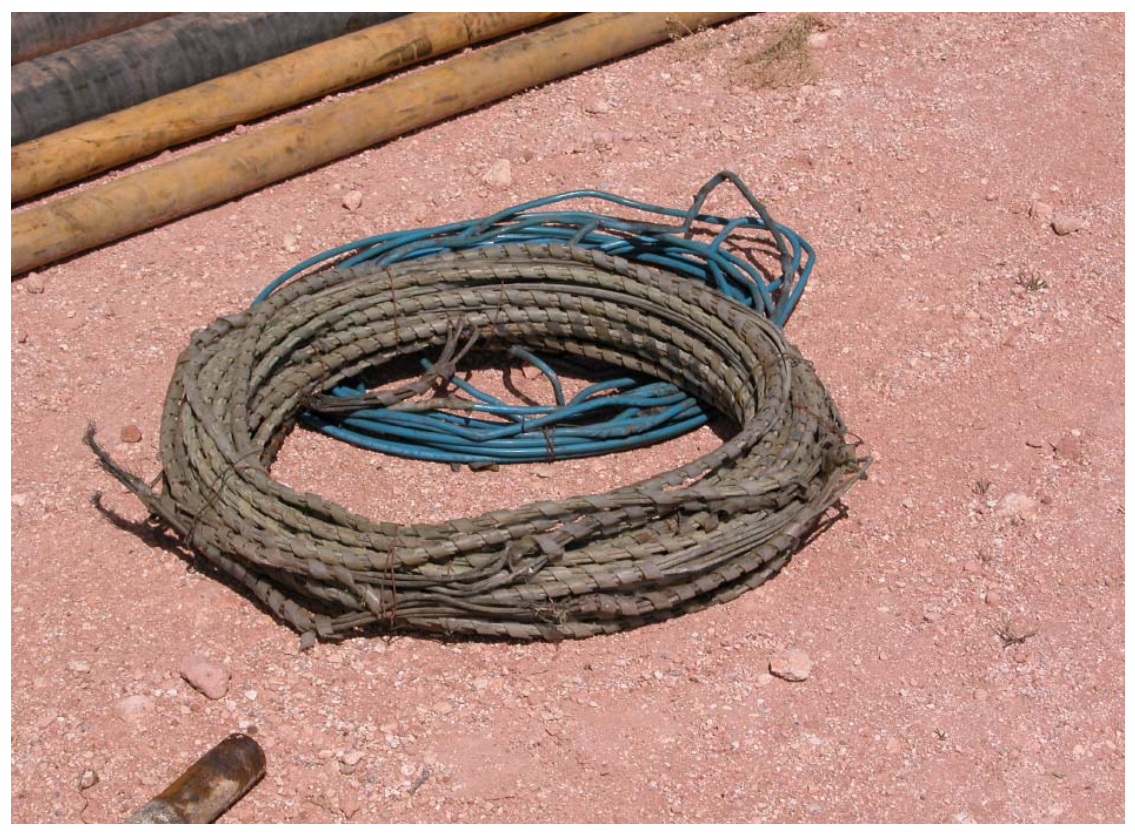

Photo 17 - Wire Pulled From Well H-6a

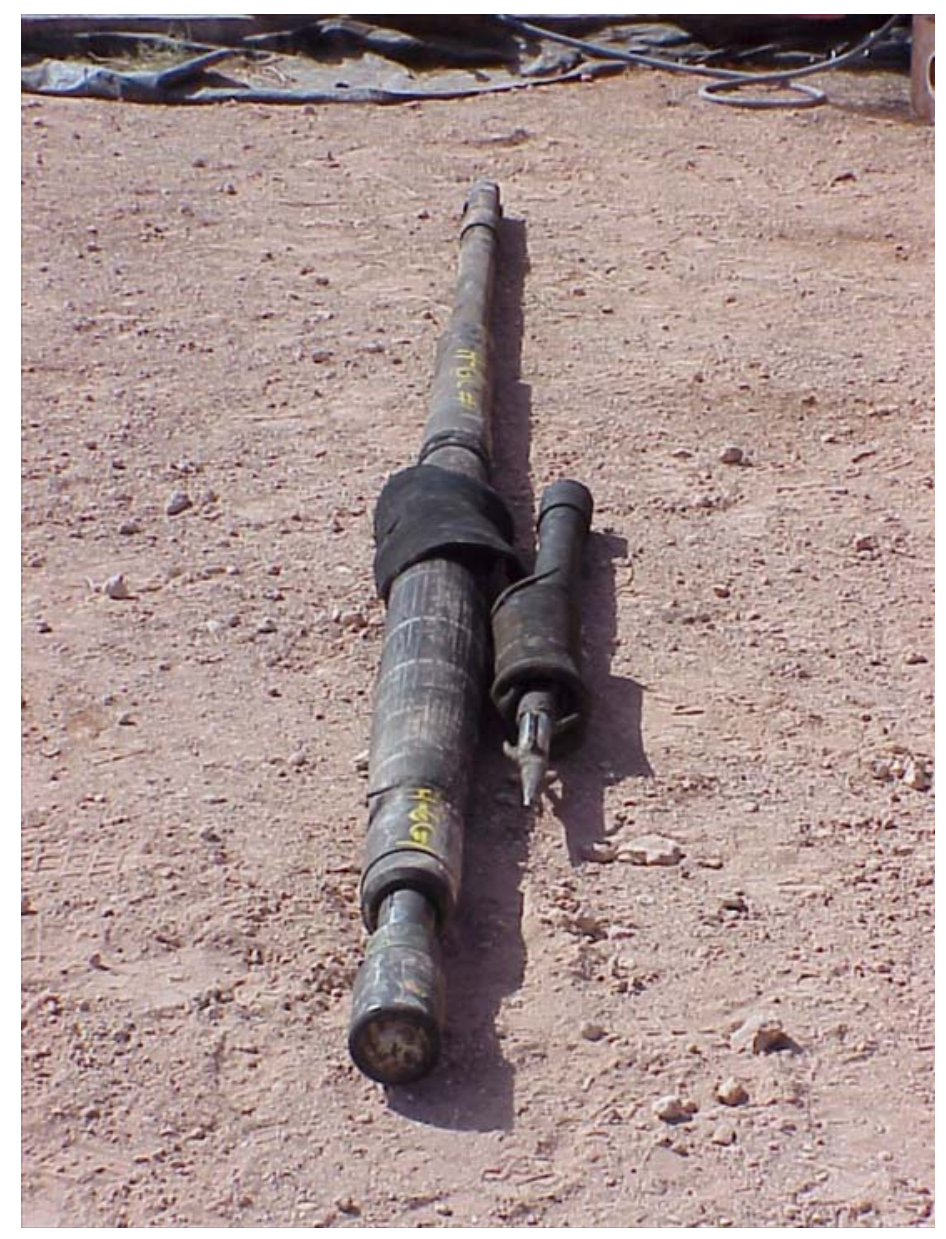

Photo 18 - Spear, Packer, and Element From Well H-6c 
Basic Data Report for Well Plugging and Abandonment and Reconfiguration Activities for Fiscal Year 2005

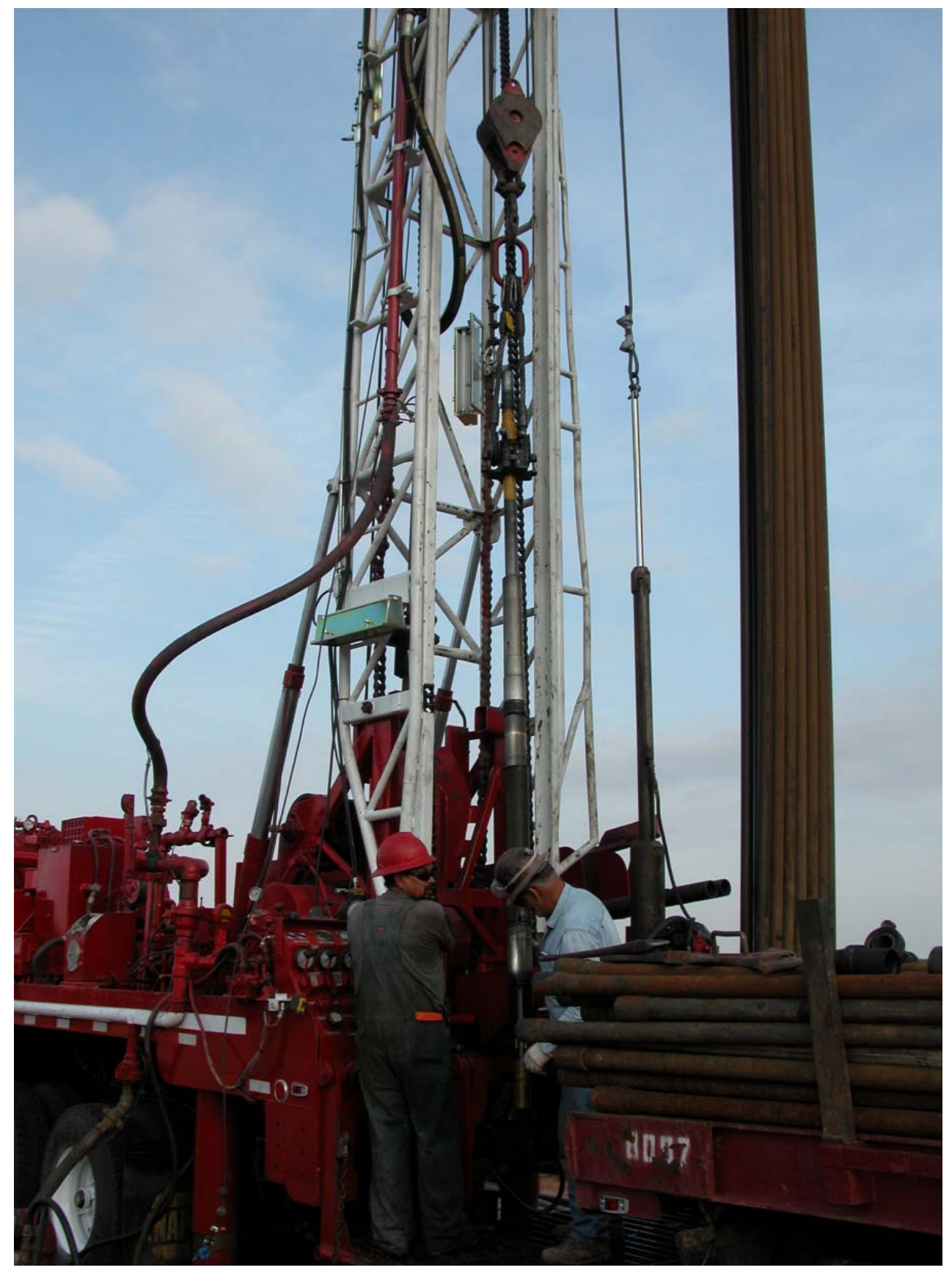

Photo 19 - J-Tool on Tubing Removing Packer From Well H-11b2 


\section{Basic Data Report for Well Plugging and Abandonment and}

Reconfiguration Activities for Fiscal Year 2005 DOE/WIPP 05-3326

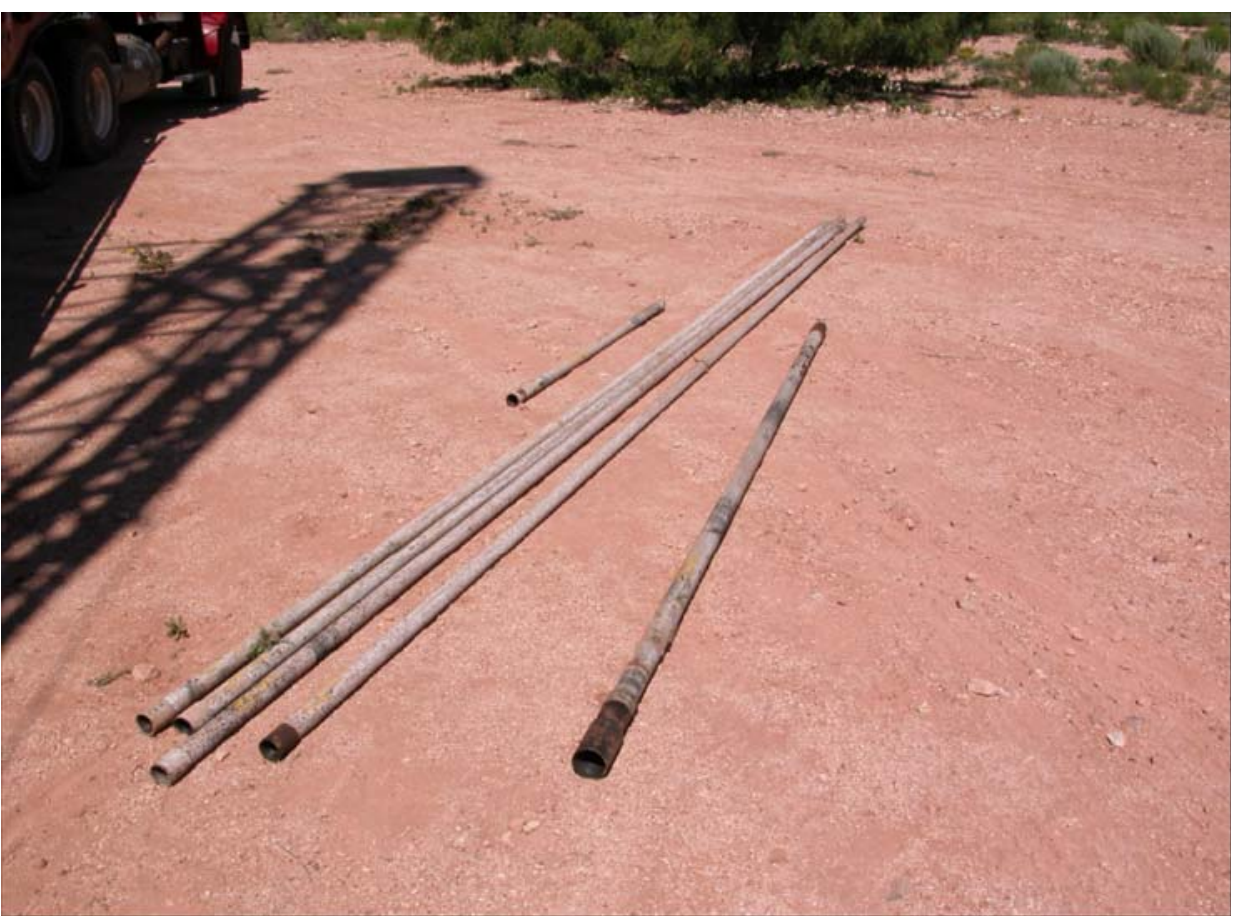

Photo 20 - Galvanized Tubing From Well H-5a

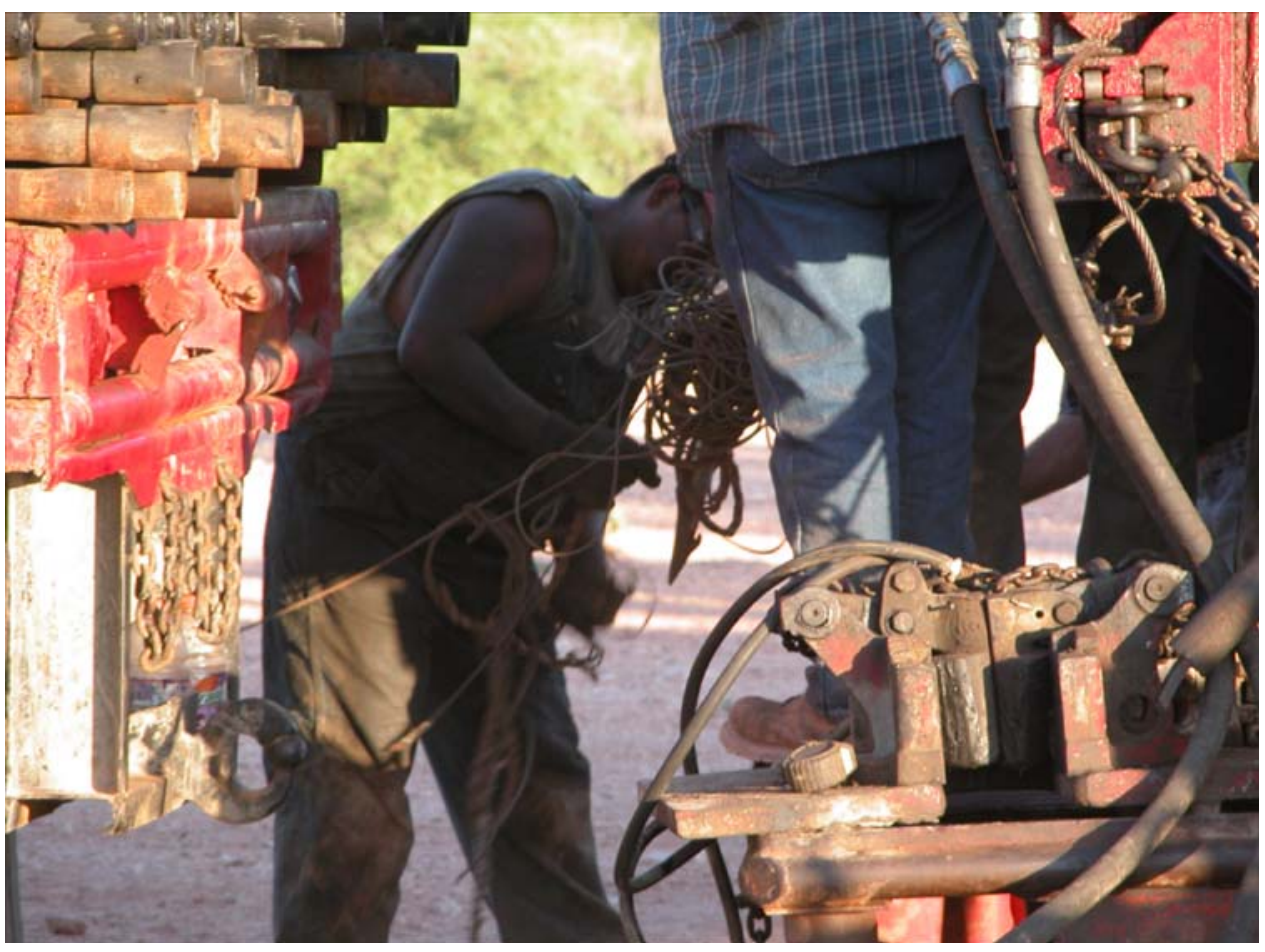

Photo 21 - Wire Removed From Well H-5a Using Barbed Spear 
Basic Data Report for Well Plugging and Abandonment and Reconfiguration Activities for Fiscal Year 2005

DOE/WIPP 05-3326

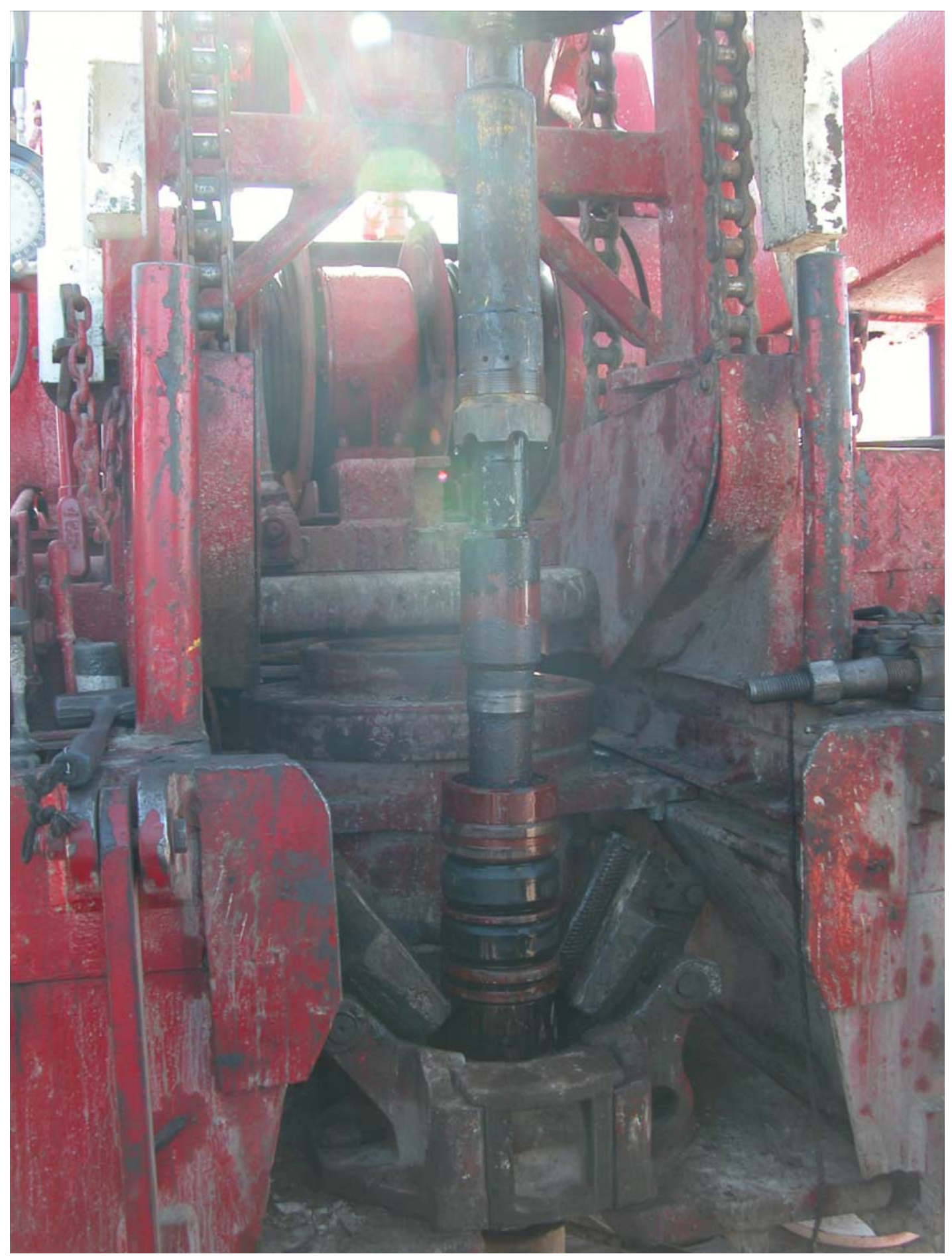

Photo 22 - Upper Bridge Plug Being Removed From H-3b1 Using J-Tool 
Basic Data Report for Well Plugging and Abandonment and Reconfiguration Activities for Fiscal Year 2005 DOE/WIPP 05-3326

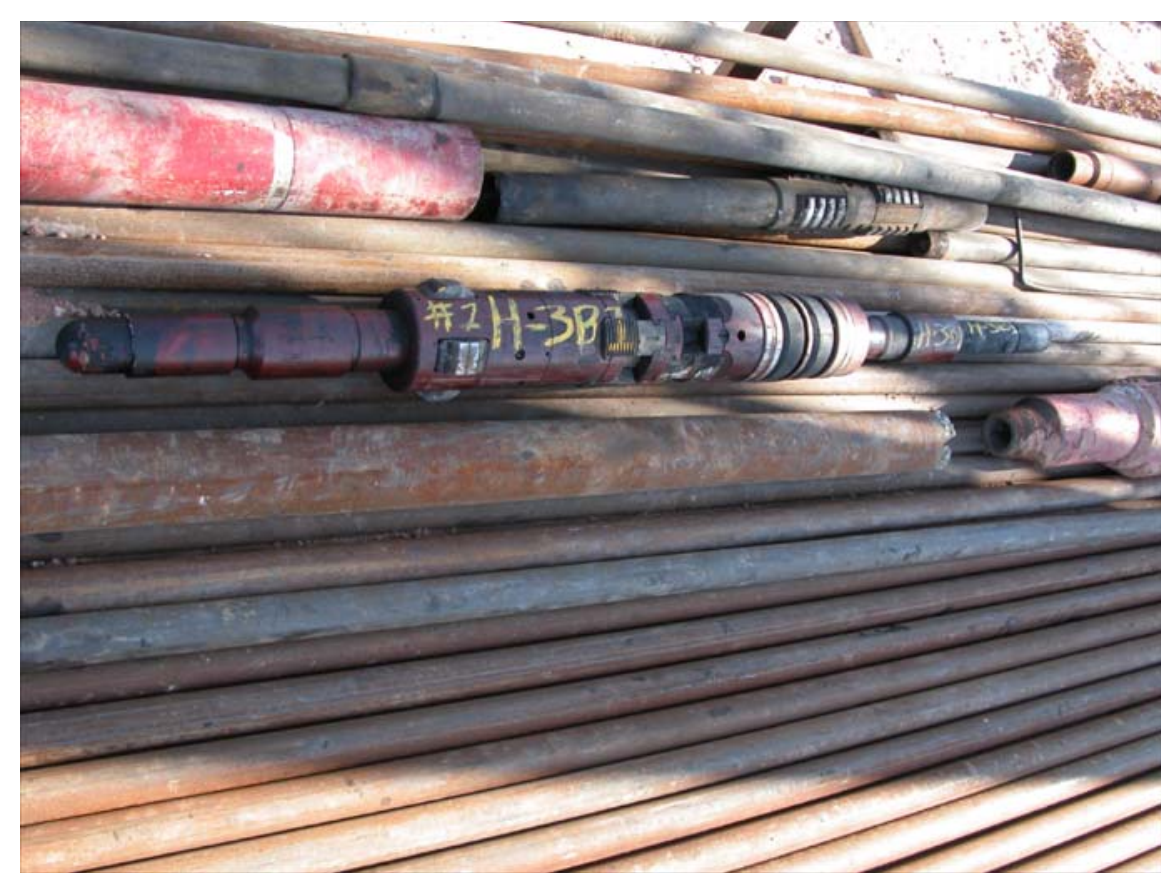

Photo 23 - Well H-3b1 Lower Packer on Pipe Trailer

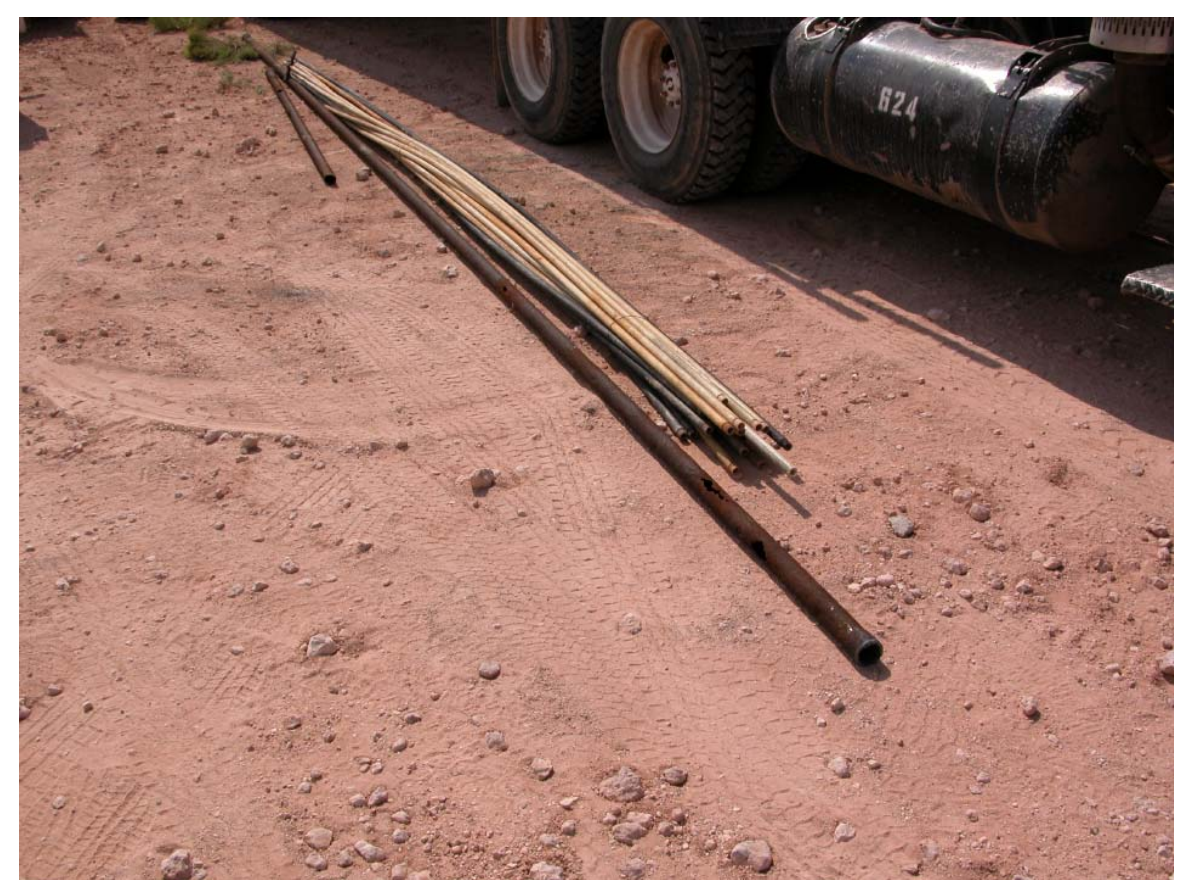

Photo 24 - PVC Tubing Removed From H-3d 


\section{Basic Data Report for Well Plugging and Abandonment and}

Reconfiguration Activities for Fiscal Year 2005

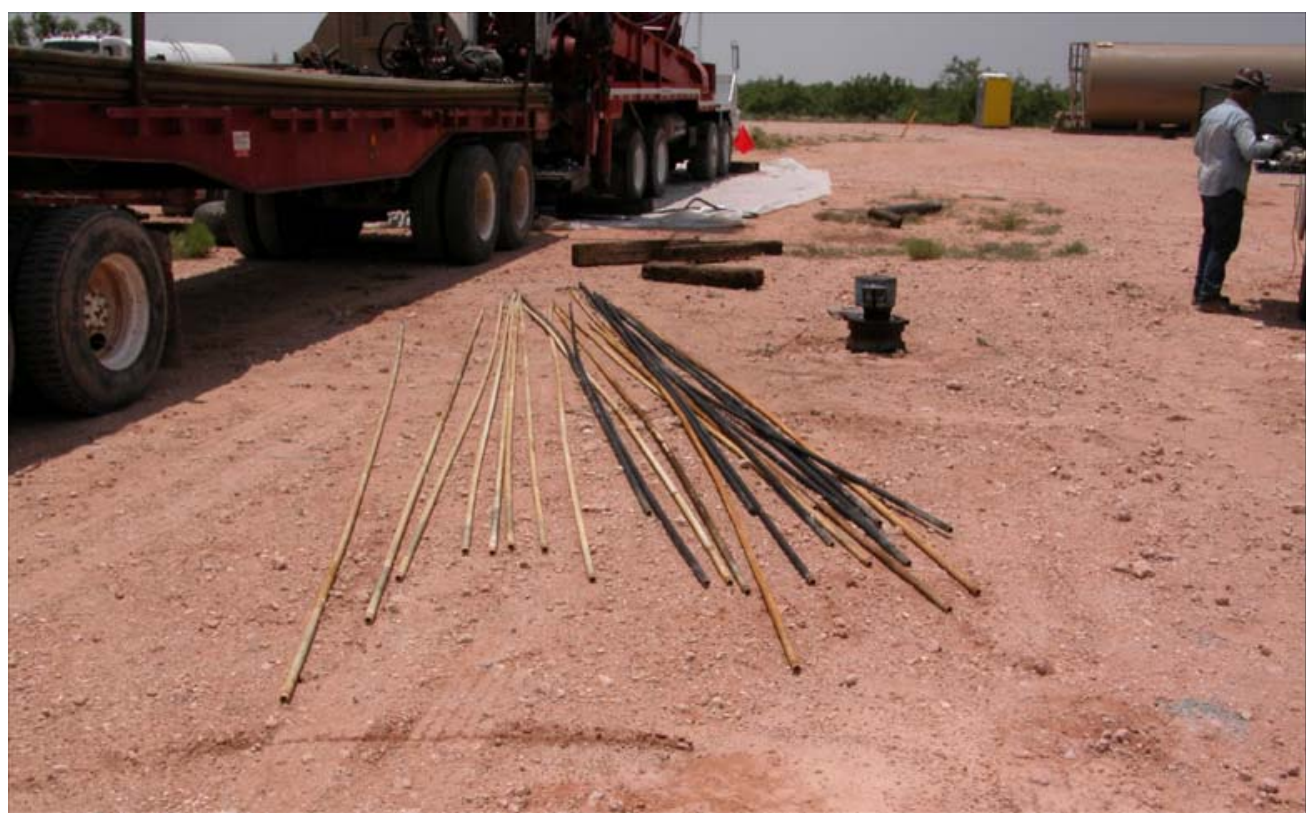

Photo 25 - PVC and Steel Tubing From Well H-3d

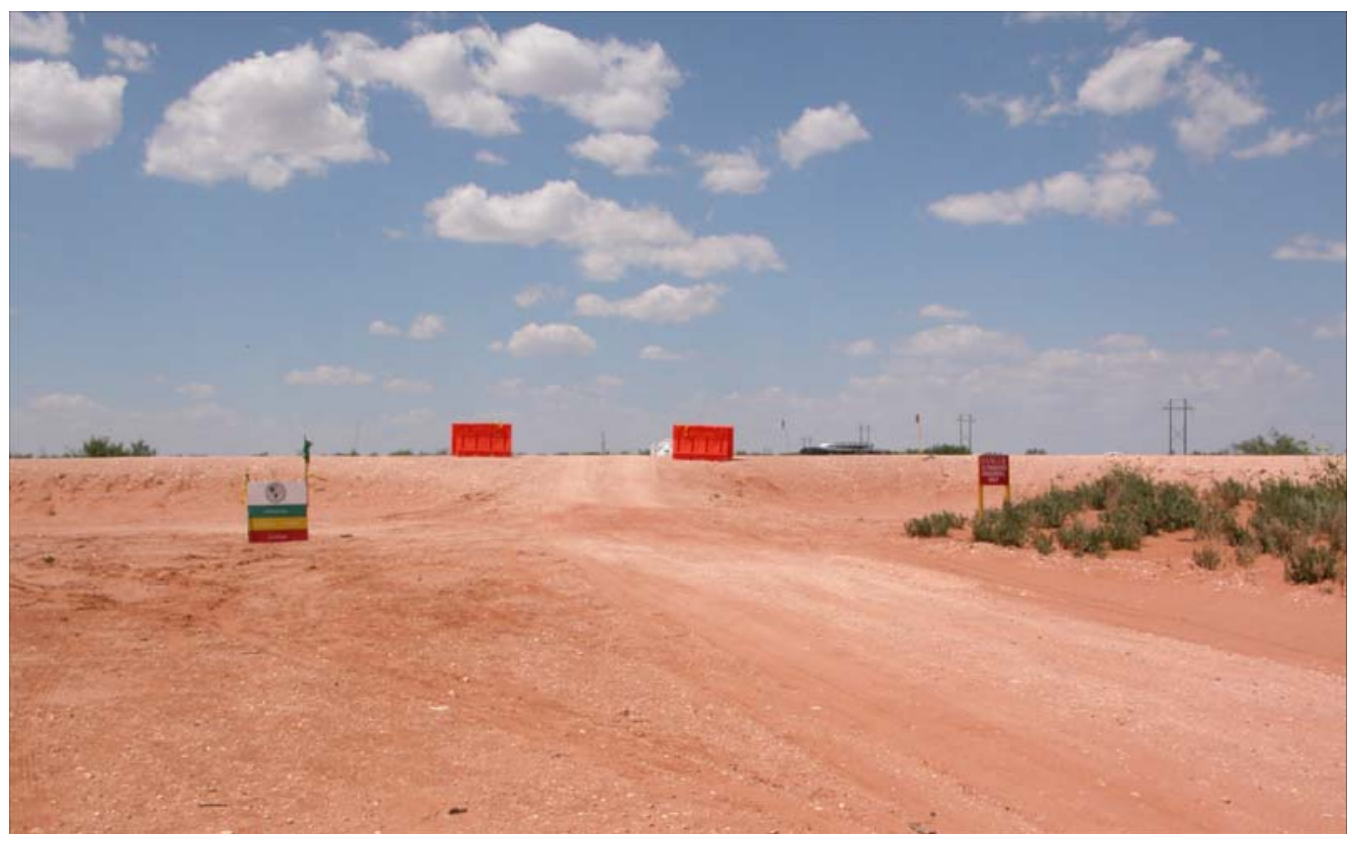

Photo 26 - Warning Signs and Barricades at Road Leading to Well WIPP-12 


\section{Basic Data Report for Well Plugging and Abandonment and}

Reconfiguration Activities for Fiscal Year 2005

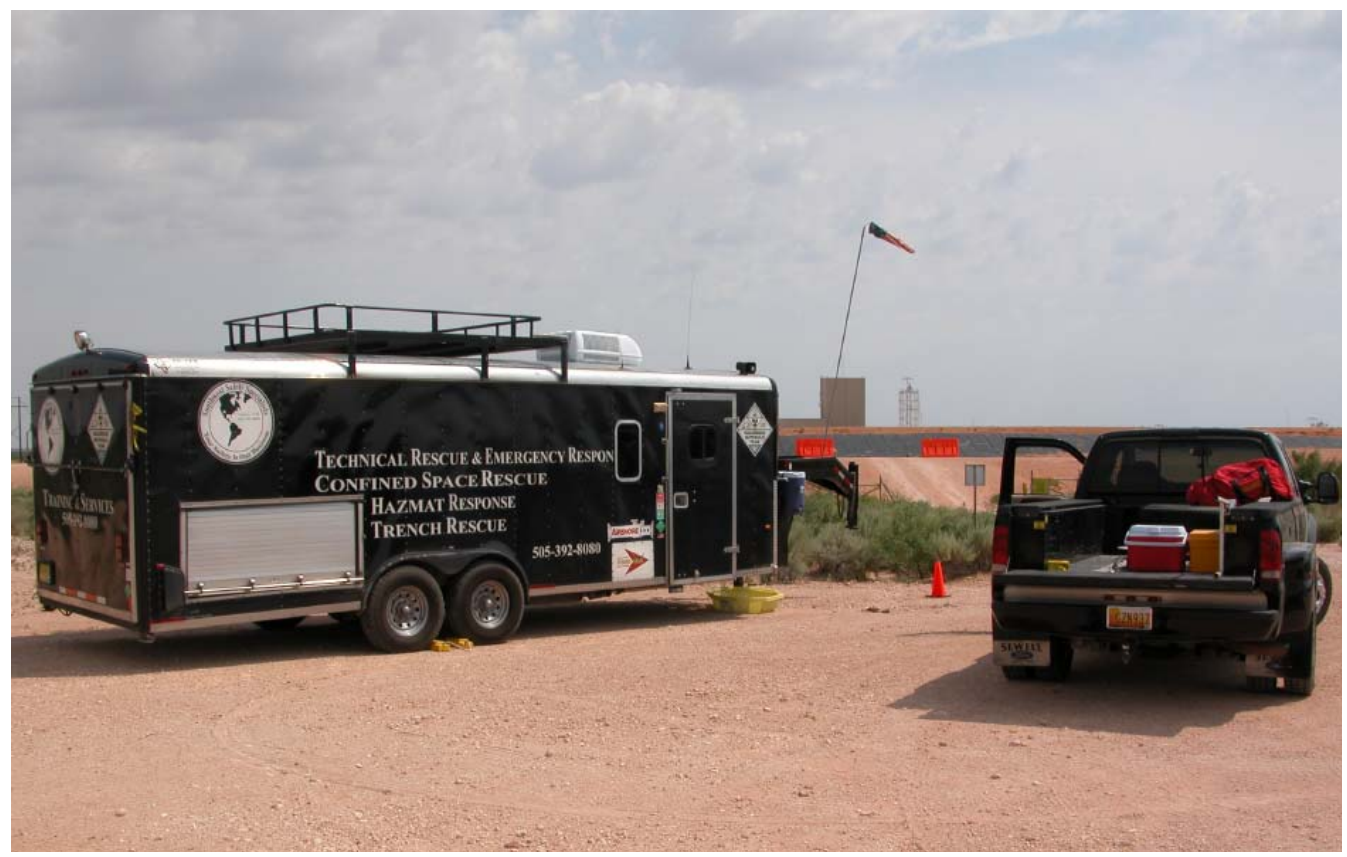

Photo 27 - Haz/Mat Trailer at Command and Control and Access Station for Well WIPP-12

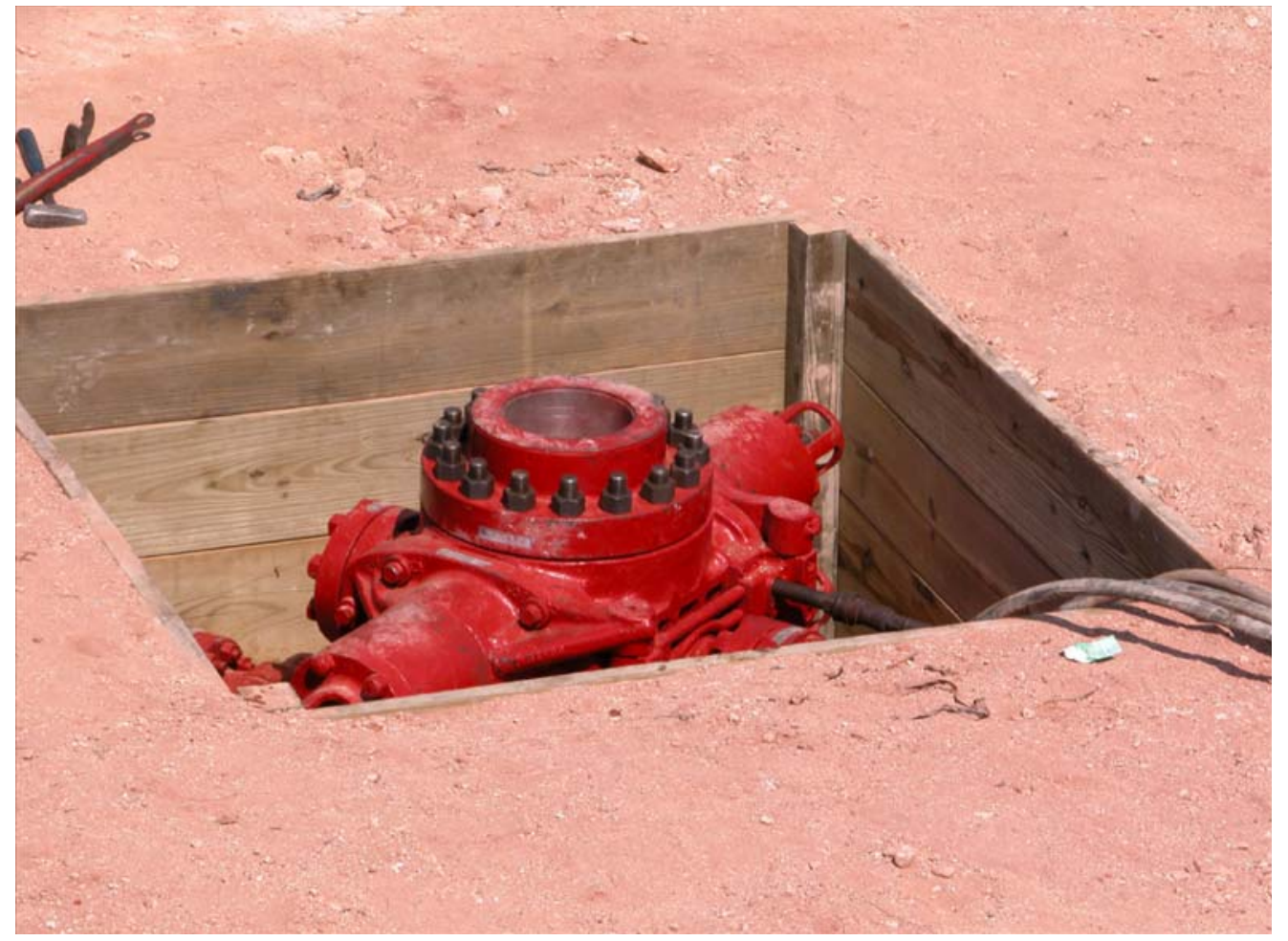

Photo 28 - Shored Cellar and BOP Assembly With Hydraulic Actuator Lines at WIPP-12 


\section{Basic Data Report for Well Plugging and Abandonment and Reconfiguration Activities for Fiscal Year 2005 \\ DOE/WIPP 05-3326}

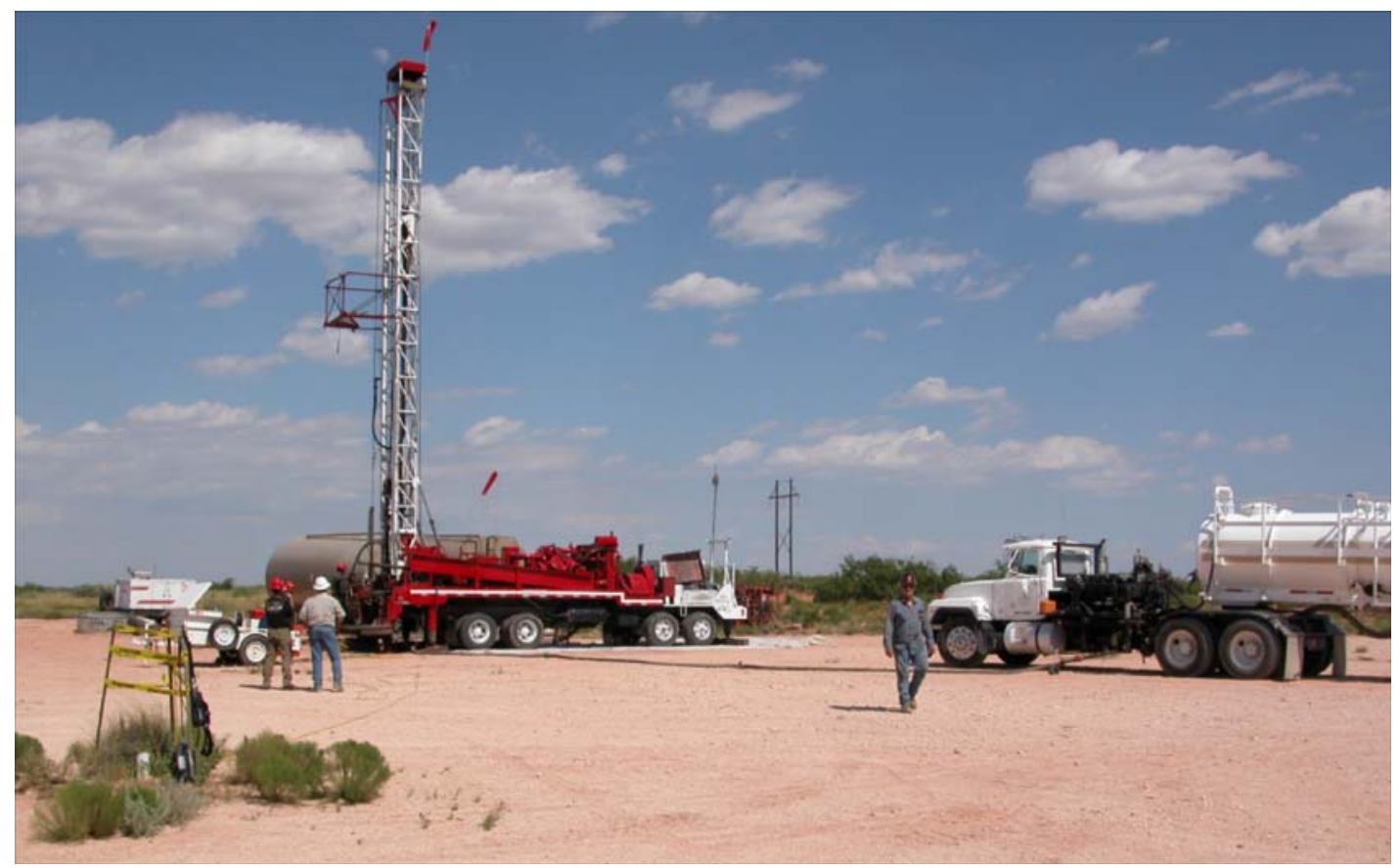

Photo 29 - Kill Truck Assembled to BOP Prior to Packer Removal at WIPP-12

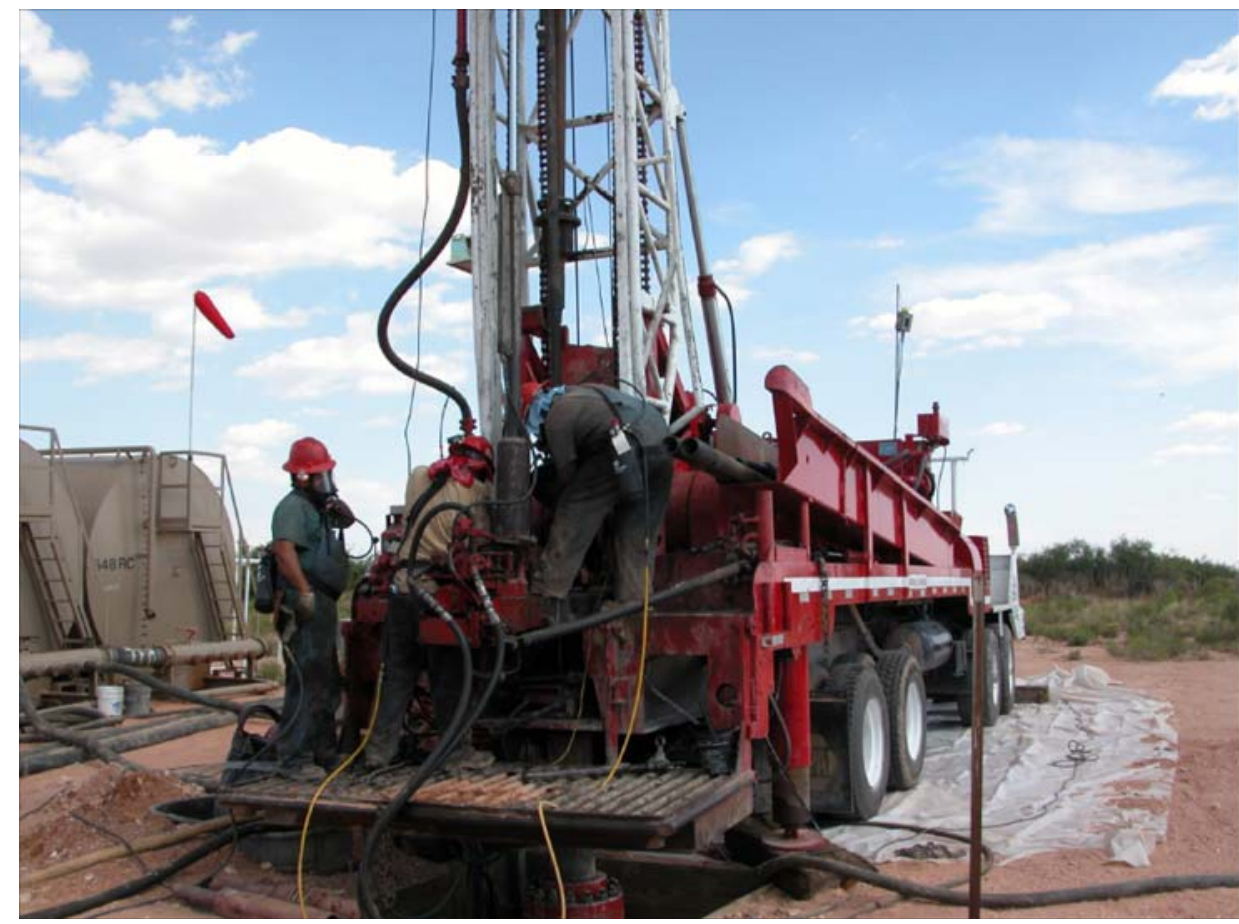

Photo 30 - Contractor Crew on Supplied Air While Removing Packer at WIPP-12 


\section{Basic Data Report for Well Plugging and Abandonment and Reconfiguration Activities for Fiscal Year 2005 DOE/WIPP 05-3326}

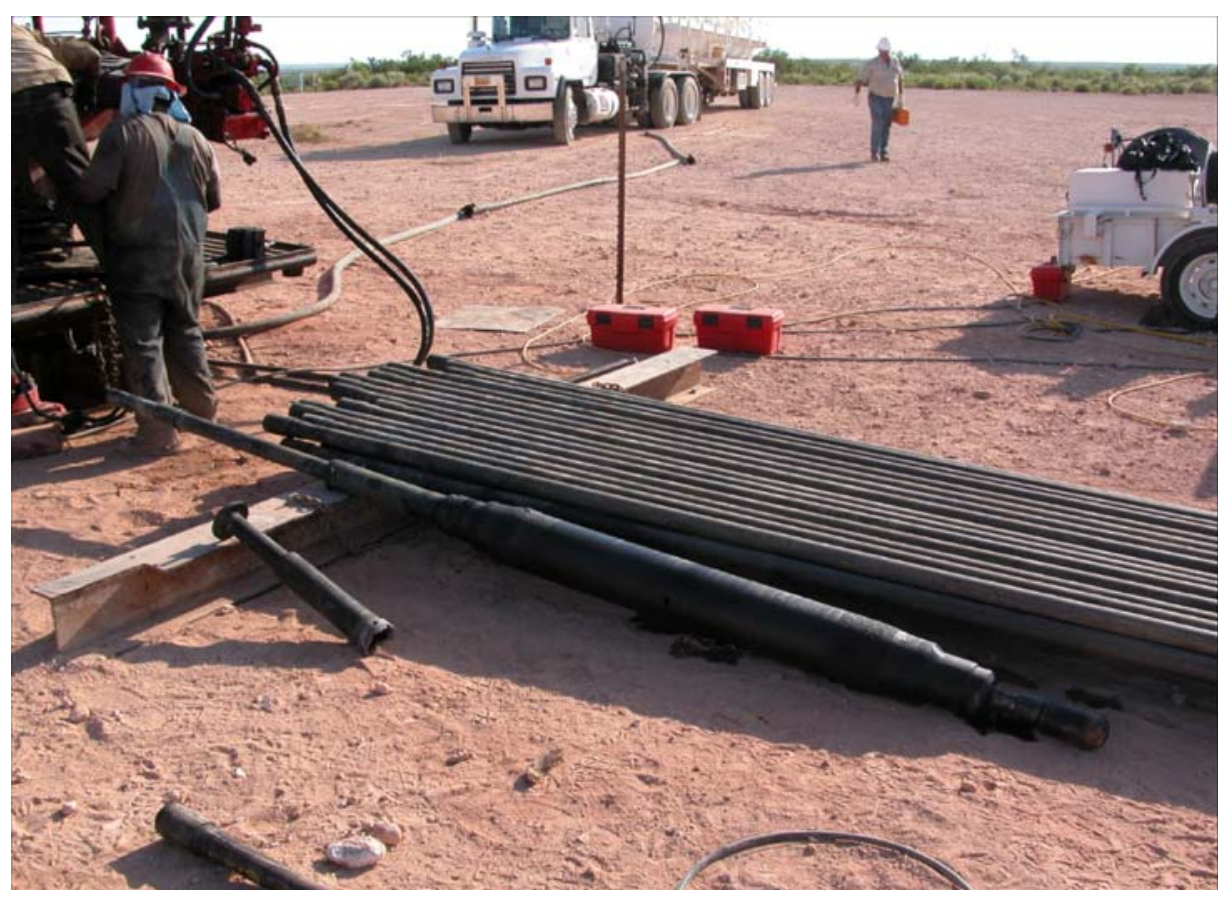

Photo 31 - Packer Removed From WIPP-12 With Kill Truck in Background. Red Tool Boxes are Escape Packs with 30-Minute Supplied Air Escape Bottles and Hoods

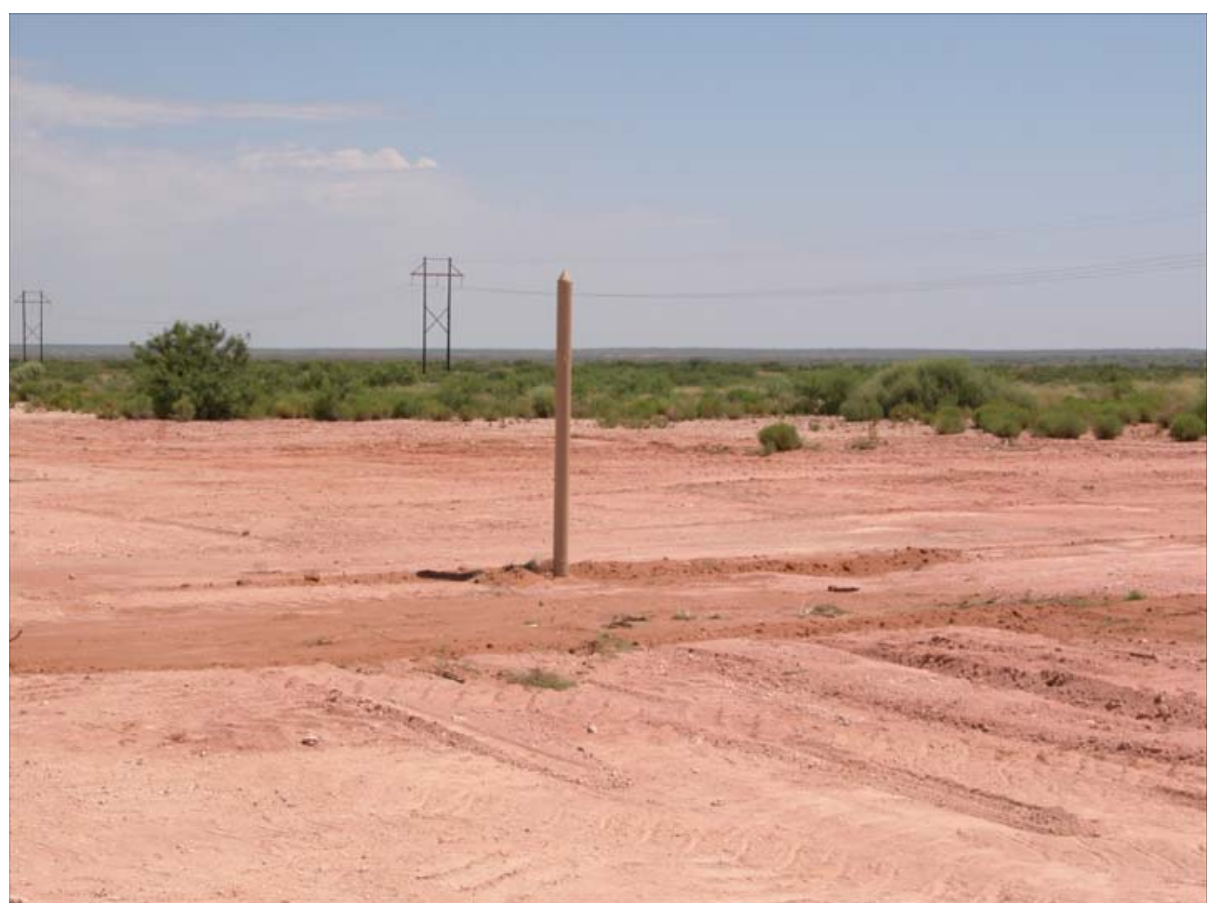

Photo 32 - Well Monument at WIPP-12 